MERARI DE FÁTIMA RAMIRES FERRARI

EFEITO MODUlatóRIO DA NICOTINA SOBRE A NEUROTRANSMISSÃo EM NúClEOS ENCEFÁlicos Responsáveis pelo Controle Cardiovascular em RATOS GENETICAMENTE HIPERTENSOS E NORMOTENSOS.

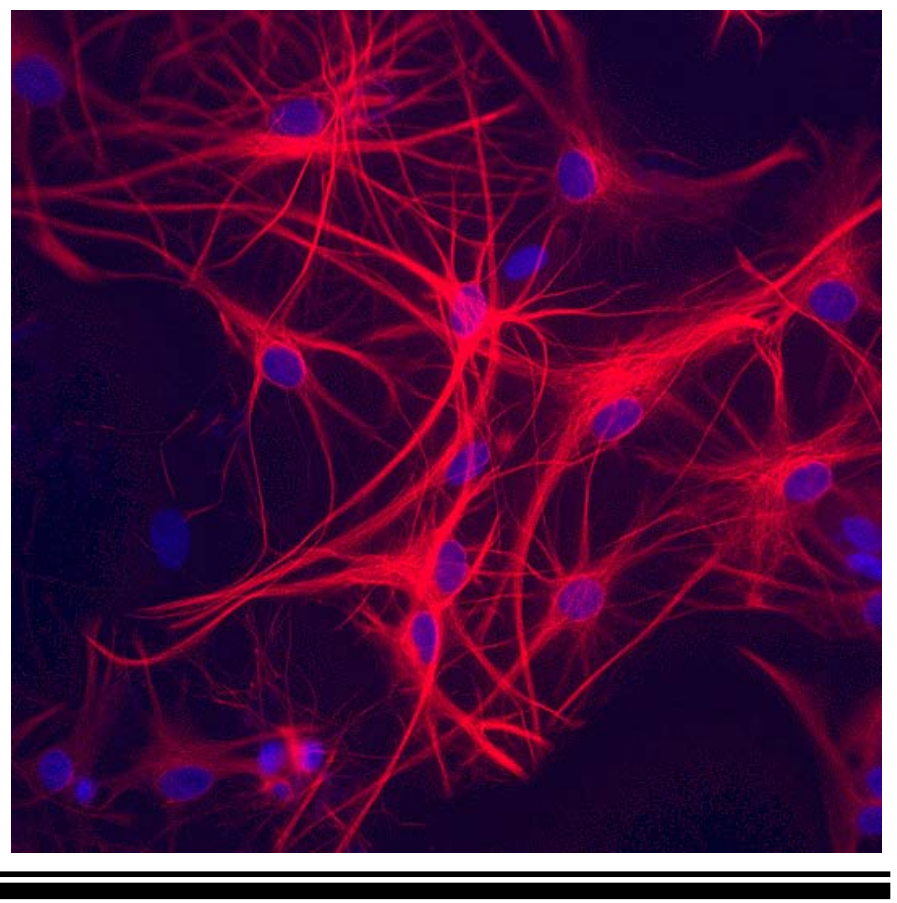

São Paulo

2006 


\section{EFEITO MODULATÓRIO DA NiCOTINA SOBRE A NEUROTRANSMISSÃo EM NÚCLEOS ENCEFÁLICOS RESPONSÁveis PElo Controle CARDiovascular EM Ratos GENETICAMENTE HIPERTENSOS E NORMOTENSOS.}

Tese apresentada ao Instituto de Biociências da Universidade de São Paulo, para a obtenção do Título de Doutora em Ciências, na Área de Fisiologia Geral.

Orientadora: Profa. Dra. Débora R. Fior Chadi 


\section{FICHA CATALOGRÁFICA ELABORADA PELO SERVIÇO DE BIBLIOTECA DO INSTITUTO DE BIOCIÊNCIAS / USP}

\begin{tabular}{|l|}
\hline F 375e \\
Ferrari, Merari de Fátima Ramires \\
Efeito modulatório da nicotina sobre a neuro- \\
transmissão em núcleos encefálicos responsáveis \\
pelo controle cardiovascular em ratos genetica - \\
mente hipertensos e normotensos / Merari de \\
Fátima Ramires Ferrari. - São Paulo : M.F.R.F., \\
2006. \\
223p. : il. \\
Tese (Doutorado) - Universidade de São Paulo, \\
Instituto de Biociências, Departamento de Fisiologia, \\
2006. \\
1. Sistema nervoso central. 2. Hipertensão. 3. \\
Nicotina. I.Universidade de São Paulo. Instituto de \\
Biociências. Departamento de Fisiologia. II. Título. \\
LC: QP 370 \\
\end{tabular}

Comissão Julgadora:

$\operatorname{Prof}(\mathrm{a}) \cdot \operatorname{Dr}(\mathrm{a})$.

$\operatorname{Prof}(a) \cdot \operatorname{Dr}(a)$.

$\operatorname{Prof}(a) \cdot \operatorname{Dr}(a)$.

$\operatorname{Prof}(\mathrm{a}) . \operatorname{Dr}(\mathrm{a})$.

Profa. Dra. Débora Rejane Fior Chadi

Orientadora 

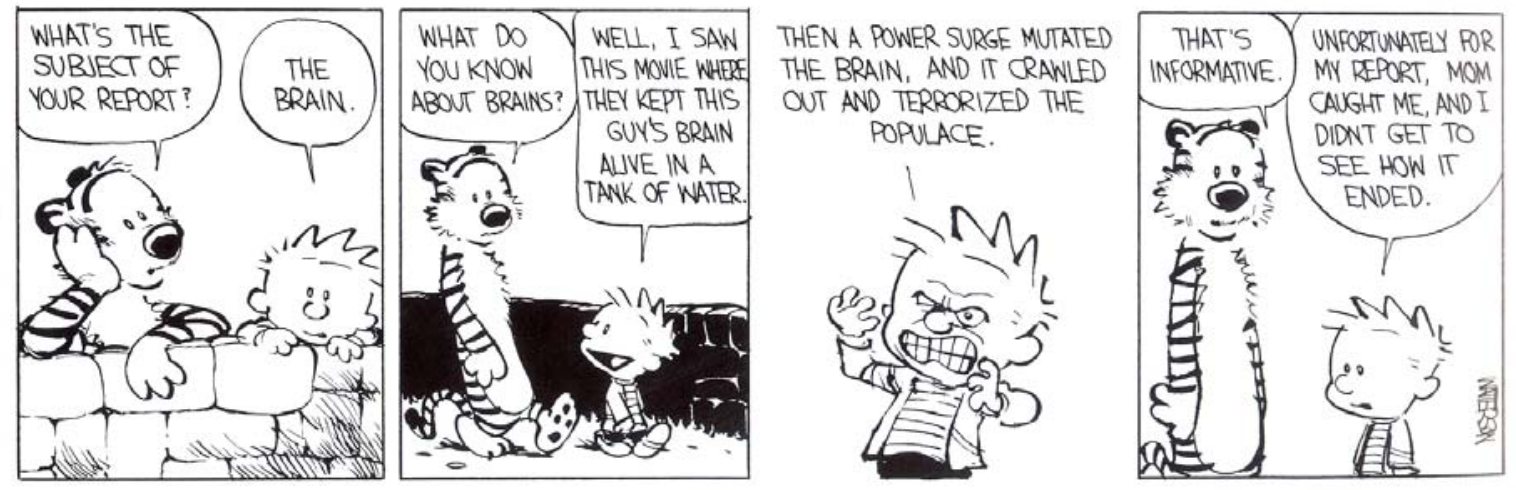

(Bill Watterson, The Complete Calvin and Hobbes) 
DEDICATÓRIA 
"Dize:

$\mathrm{O}$ vento do meu espírito

soprou sobre a vida.

E tudo que era efêmero

se desfez.

E ficaste só tu, que és eterno...”

(Cecília Meireles)
Para Renato, uma pessoa sem outra igual, que sabe dizer as palavras certas nos momentos certos, sempre está ao meu lado (mesmo quando da distância), pela compreensão, companheirismo e apoio sempre constantes. A quem admiro muito. Com todo meu amor. 
Para meus pais Willian e BERNARDETE pelo incentivo incondicional e carinho sem limites. Sem vocês, este trabalho certamente não teria acontecido. 
AgRADECIMENTOS 


\section{AgradeCimentos}

A Débora pela orientação, em seu mais amplo significado, pelas oportunidades que me foram dadas, e incentivo para sempre aproveitá-las, pela dedicação aos seus alunos, pela contribuição essencial para o desenvolvimento da minha carreira, em quem me inspiro como cientista, e por ter um dia acreditado numa caloura sem noção alguma de neurociência.

Aos meus grandes amigos do laboratório: Andreas, Daniel, Jessica, Regiane, Renato, Sergio M. Soares, Sérgio M. da Silva e Karen, que sempre estiveram muito presentes durante o desenvolvimento deste projeto, seja ajudando durante os experimentos e discussões científicas, seja nas festas sempre animadas e, sobretudo, necessárias.

Ao Prof. Dr. Gerson Chadi pelas sugestões e discussões muito pertinentes, e pela sempre disponibilização de seu laboratório.

Aos colegas do Laboratório de Neurologia Experimental da Faculdade de Medicina da Universidade de São Paulo pelos bons momentos compartilhados.

Ao Prof. Dr. Joel Cláudio Heimann e a Karen Lucasechi Lopes do Departamento de Fisiopatologia da Faculdade de Medicina da Universidade de São Paulo que me ensinaram a coletar sangue das veias caudais do rato.

A Antônio Carlos Magnanelli da Fundação Hemocentro/Hospital das Clínicas da Faculdade de Medicina da Universidade de São Paulo, ao Dr. Enrique Rosa Sanchéz, à Profa. Dra. Zulma F. da Silva Ferreira e à Profa. Dra. Regina Pekelmann Markus do Departamento de Fisiologia do Instituto de Biociências da Universidade de São Paulo pela grande ajuda durante a padronização da cromatografia líquida de alta eficiência.

Para meus irmãos Gerson e Jorge pelas brincadeiras, brigas, apoio, incentivo e, obviamente, pela grande contribuição para que minha paciência fosse exercitada e se elevasse aos níveis que se espera de um cientista brasileiro. 
To Dr. Mohan K. Raizada from the Department of Physiology and Functional Genomics at the Brain Institute of the College of Medicine - University of Florida for the amazing opportunity that he propiciated to me at his laboratory, for the scientific and non-scientific discussions, for the encouragements, for the improvement of this study and of myself.

To Dr. Shereeni Veerasingham for the priceless friendship and support in almost all of the experiments carried out at Dr. Raizada's Laboratory.

To Dr. Jorge Vázquez and Dr. Hongwei Li for the help with binding and real time PCR experiments.

To Dr. Masanobu Yamazatu for the help with immunocytochemistry and with the pups.

To Carolyn Mendez for the help with western blotting experiments.

To Fan Lin for the cell culture.

To Kelly Deuerling, Nichole Herring and Jackie Treat for technical support.

To Dr. Carlos Diez-Freire and Dr. Shant Der Sarkissian for the friendship.

To all the "CLOnes" for the great experience at the Collegiate Living Organization - University of Florida.

E para todos aqueles que, de alguma forma, tornaram possível e prazerosa a finalização deste estudo, mas não foram mencionados somente porque minha memória ficou pequena diante da quantidade de pessoas que me foram (e são) importantes. Meus sinceros agradecimentos:

\section{MUITO OBRIGADA A TODOS!!!}

Este estudo foi financiado pelas seguintes agências de fomento:

FAPESP 01/10471-3 (bolsa para doutorado direto - Merari F. R. Ferrari)

CAPES BEX0140/05-8 (bolsa para estágio no exterior- Merari F.R.Ferrari)

FAPESP 01/10472-0 (auxílio regular para pesquisa - Dra. Débora R.F. Chadi)

CNPq (auxílio para pesquisa - Dra. Débora R. Fior Chadi)

NIH (auxílio para pesquisa - Dr. Mohan Raizada) 
ÍNDICE 


\section{ÍNDICE}

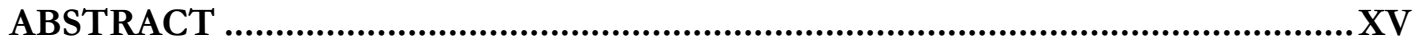

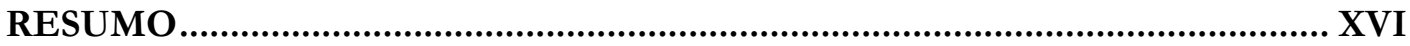

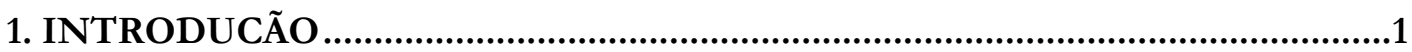

1.1. O controle da pressão arterial pelo sistema nervoso central.................................... 4

1.2. O sistema catecolaminérgico e o controle central da pressão arterial................. 10

1.3. O neuropeptídeo Y e o controle central da pressão arterial.................................. 12

1.4. O sistema glutamatérgico e o controle central da pressão arterial. ...................... 12

1.5. O sistema angiotensinérgico e o controle central da pressão arterial................... 14

1.6. O sistema colinérgico e o controle central da pressão arterial................................ 19

1.7. A ação da nicotina sobre a pressão arterial............................................................... 21

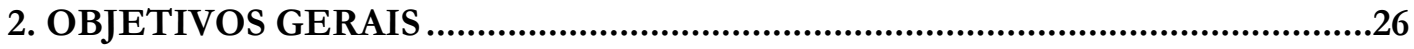

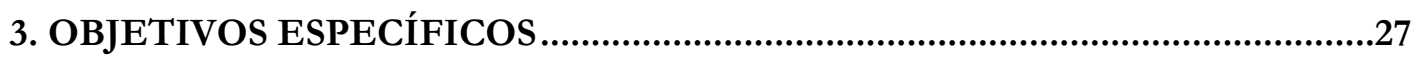

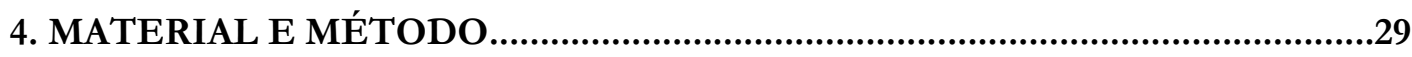

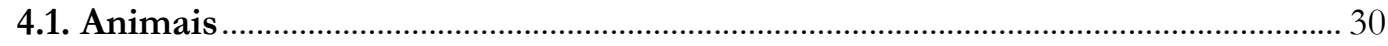

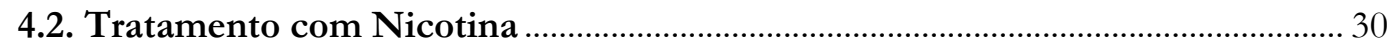

4.3. Registro indireto da pressão arterial e freqüência cardíaca …………………........ 31

4.4. Quantificação da concentração plasmática de nicotina e cotinina ....................... 31

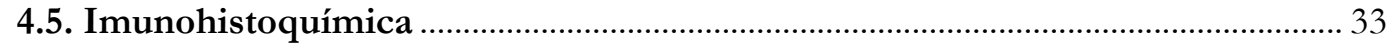

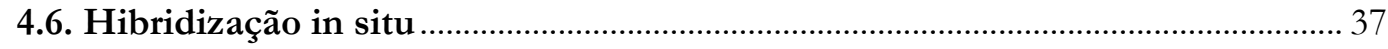

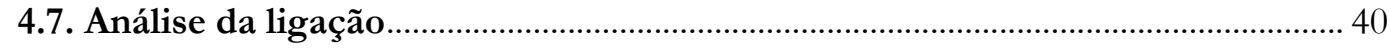

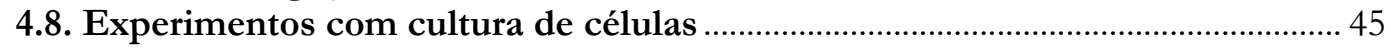

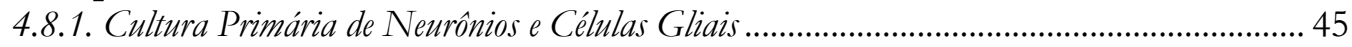

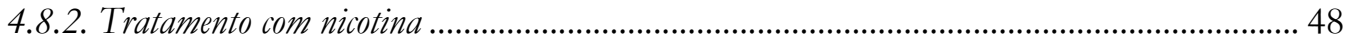

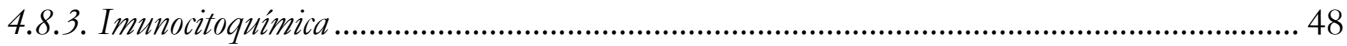

4.8.4. Ligação

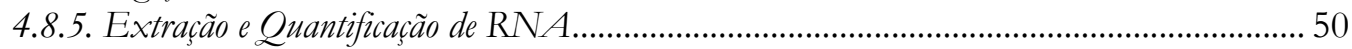

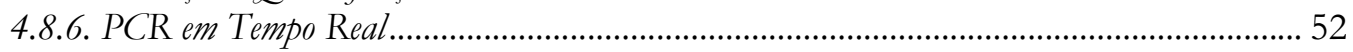

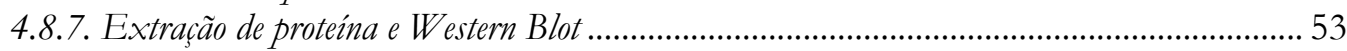

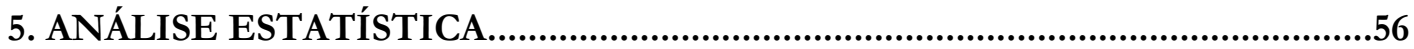

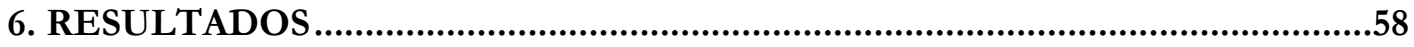

6.1. Quantificação da nicotina e cotinina plasmáticas ………………………………....... 58

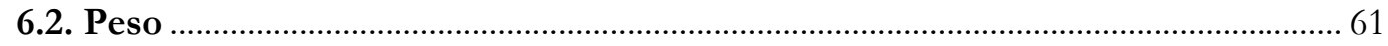

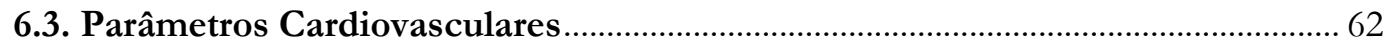

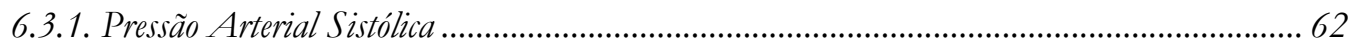

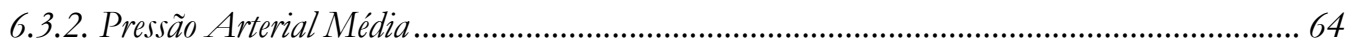

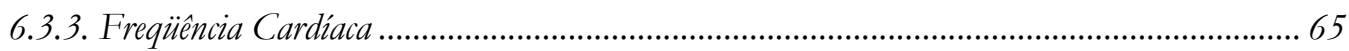

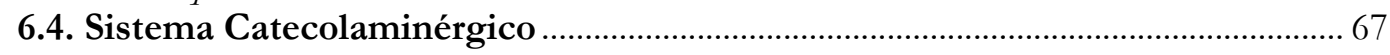

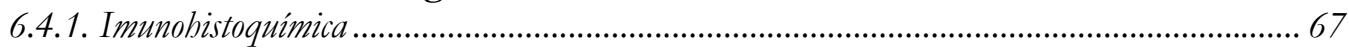

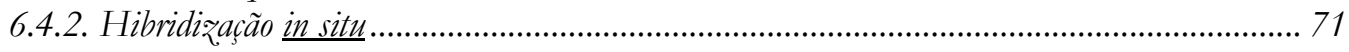

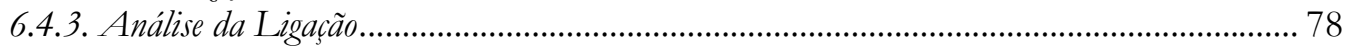

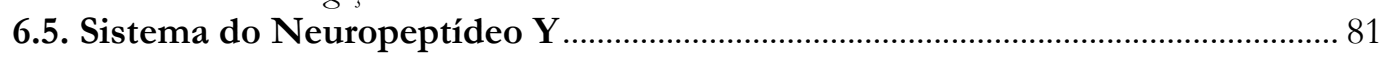

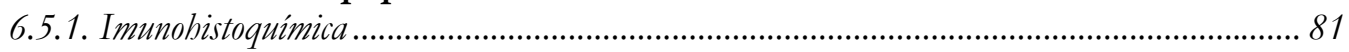

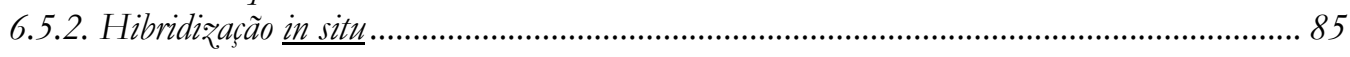




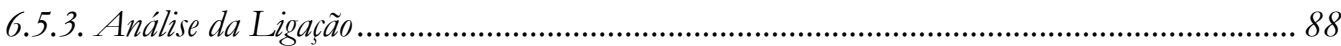

6.6. Sistema Angiotensinérgico .................................................................................. 92

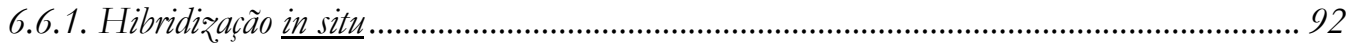

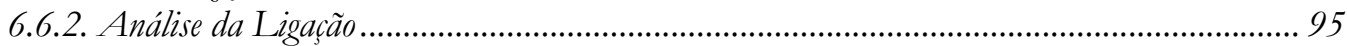

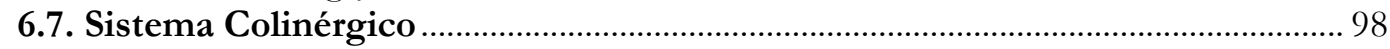

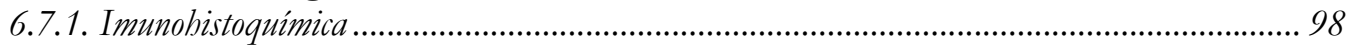

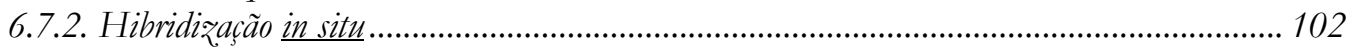

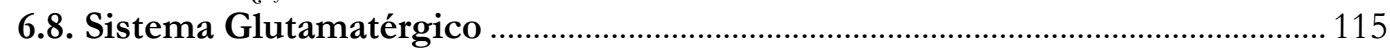

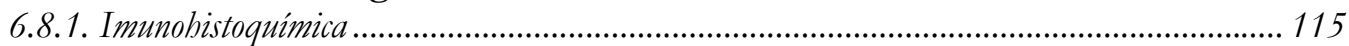

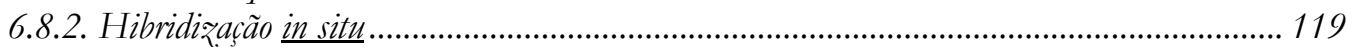

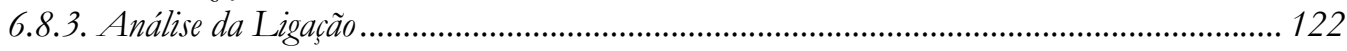

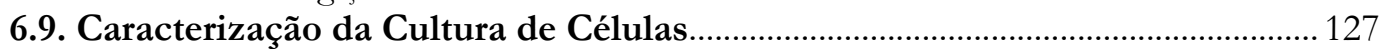

6.10. Análise da Ligação dos Receptores $\mathbf{A T}_{1}$ e $\mathbf{A T}_{2}$ de Angiotensina II .................. 129

6.11. Avaliação de RNAm do sistema angiotensinérgico. .......................................... 133

6.12. Quantificação de proteínas do sistema angiotensinérgico …………................. 147

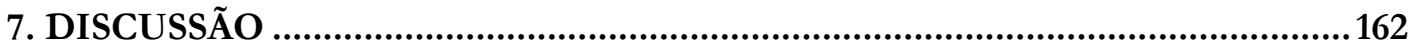

7.1. Os ratos SHR, os parâmetros cardiovasculares e o tratamento com nicotina.164

7.2. O sistema catecolaminérgico e do NPY após tratamento com nicotina .......... 166

7.3. O sistema colinérgico após tratamento com nicotina …………………………..... 169

7.4. O sistema glutamatérgico e o tratamento com nicotina. ........................................ 171

7.5. O sistema angiotensinérgico e o tratamento com nicotina. ................................. 174

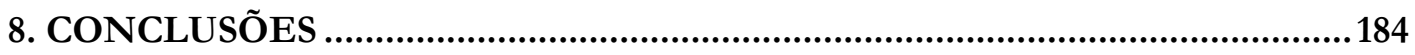

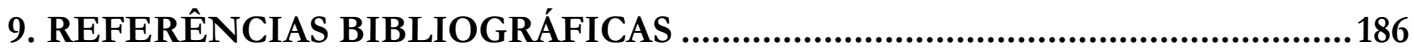

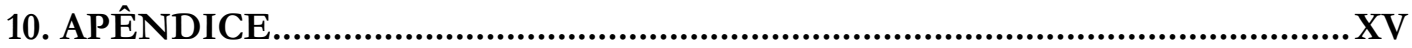


AbStract e Resumo 


\begin{abstract}
Nicotine is one of the most important agents for cardiovascular diseases in tobacco smoking. This alkaloid acts in the blood stream, but it also crosses the blood-brain-barrier and participate in the regulation of pivotal neurotransmitter systems for the blood pressure control and, eventually, for hypertension development. In this context, nicotine abuse could be very relevant to individuals carrying genetic factors to hypertension. The objectives of the present work were to study neurotransmitter system in brain cardiovascular areas involved in the control of blood pressure after chronic peripheral nicotine exposure, as well as to evaluate nicotine influence on essential hypertension development in spontaneously hypertensive (SHR) and normotensive rats (WKY). By means of immunohistochemistry, binding, in situ hybridization, neuron and glial culture, real time PCR and Western Blotting, we have demonstrated that chronic treatment with nicotine not only anticipated but also intensified hypertension on SHR. WKY rats did not showed any change on blood pressure. We observed no evidences of the involvement of neuropeptide $\mathrm{Y}$ and catecolamines systems in the development of hypertension after nicotine treatment. However, it seems that the glutamatergic system is, at least in part, responsible for the hypertension development after chronic nicotine exposure. To study the angiotensinergic system we cultivated neuron and glial cells from SHR and WKY rats and treated them with nicotine. The responses of this system agree with the hypothesis that nicotine interacts with angiotensin to promote hypertension only in the hypertensive strain. In conclusion, results presented herein support the hypothesis that nicotine modulates neurotransmitter systems that might have relevant functions in the development and intensification of hypertension in SHR .
\end{abstract}




\section{Resumo}

As ações cardiovasculares decorrentes do tabagismo devem-se principalmente à nicotina. $\mathrm{O}$ alcalóide exerce suas funções quando na corrente sangüínea, mas também atravessa a barreira hemato-encefálica onde pode participar da regulação de sistemas de neurotransmissão importantes para o controle central da pressão arterial e, eventualmente, desenvolvimento da hipertensão. Portanto, o abuso à nicotina pode ser especialmente relevante para indivíduos com predisposição genética à hipertensão. Desta forma, os objetivos do presente trabalho foram o de estudar os sistemas de neurotransmissão em núcleos encefálicos envolvidos no controle cardiovascular após tratamento crônico periférico com nicotina, assim como avaliar a influência da nicotina sobre o desenvolvimento da hipertensão essencial em ratos espontaneamente hipertensos (SHR) e compará-los a ratos normotensos (WKY). Para isso, utilizaram-se técnicas como a imunohistoquímica, análise da ligação de receptores, hibridização in situ, cultura de células neuronais e gliais, PCR em tempo Real e Western Blotting. Nossos resultados demonstraram que o tratamento crônico com nicotina não só antecipou o desenvolvimento como também intensificou a hipertensão nos animais SHR. Os ratos WKY não tiveram a pressão arterial alterada. De modo geral, o efeito do alcalóide sobre os sistemas catecolaminérgico e do neuropeptídeo Y não parece ter relação com a antecipação e a intensificação da hipertensão nos ratos SHR. O sistema glutamatérgico está, pelo menos em parte, relacionado à antecipação e intensificação da hipertensão em ratos SHR após exposição crônica à nicotina. $\mathrm{O}$ tratamento com nicotina gerou evidências de que o alcalóide interage com o sistema angiotensinérgico a fim de promover a hipertensão em ratos SHR. Por fim, os resultados apresentados aqui indicam que a nicotina modula diferentes sistemas de neurotransmissão, os quais podem estar envolvidos na antecipação e intensificação da hipertensão em ratos SHR submetidos ao tratamento com nicotina. 
INTRODUÇÃO 


\section{INTRODUÇÃo}

A pressão arterial é um dos parâmetros fisiológicos sob mais intensa e refinada regulação. É a partir da adequada perfusão sangüínea dos órgãos e tecidos, proporcionada diretamente através do controle da pressão, que a saúde se torna presente. Para isso, os mecanismos que controlam a pressão sanguínea devem ser muito precisos, pois definem o sucesso da vida do indivíduo. Se a pressão arterial for muito baixa, o fluxo sangüíneo não será suficiente para a adequada nutrição dos tecidos; por outro lado, o aumento exagerado da pressão arterial pode provocar danos a todo o sistema cardiovascular através da falência cardíaca e dos vasos, assim como aos rins e até ao encéfalo, no caso de acidentes vasculares cerebrais.

Conhecendo a importância da pressão arterial, é fácil entender a complexidade de sua regulação e o envolvimento de diversos órgãos e sistemas na modulação deste parâmetro. Dentre eles destacam-se os rins e o sistema nervoso central.

Os rins regulam a pressão arterial através de 2 mecanismos principais: o hemodinâmico e o hormonal. $\mathrm{Na}$ regulação hemodinâmica, o aumento da pressão faz com que haja aumento da diurese através do aumento da filtração glomerular. Com o volume urinário aumentado há diminuição do volume dos fluídos extracelulares e consequentemente sangüíneo. A diminuição do volume sangüíneo faz com que haja menor débito cardíaco levando à diminuição da pressão arterial $(\mathrm{PA})$, pois esta é o resultado do produto da resistência periférica e do (RP) e do débito cardíaco (DC) $(\mathrm{PA}=\mathrm{RP} \times \mathrm{DC})$. A regulação hormonal da pressão arterial pelos rins dá-se através da ativação do sistema renina-angiotensina-aldosterona. A queda no fluxo sangüíneo renal, que pode ter sido provocada pela diminuição da pressão arterial, estimula a liberação da enzima renina pelas células justaglomerulares. Esta enzima, em associação com outras, torna possível a formação da angiotensina II que é um potente agente vasoconstrictor, a qual leva a um aumento na resistência periférica e, 
consequentemente, aumento na pressão arterial. Além disso, a angiotensina circulante pode atravessar a barreira hematoencefálica em algumas regiões do cérebro, como o órgão subfornical, e provocar aumento da atividade simpática, pois o órgão subfornical envia projeções para o núcleo paraventricular do hipotálamo que modula diretamente a atividade simpática, neste caso aumentando-a. A aldosterona também é um hormônio importante que estimula a reabsorção de sais e água pelos rins favorecendo o aumento do volume sangüíneo circulante e da pressão arterial.

O sistema nervoso central é capaz de controlar a pressão arterial imediatamente após qualquer alteração detectada pelos baro- e quimiorreceptores localizados no arco aórtico e no seio carotídeo, respectivamente, através de modulação do sistema nervoso autônomo (simpático e parassimpático). A pressão arterial pode ser regulada a longo prazo também pelo sistema nervoso central através da modulação dos nervos simpáticos e de hormônios produzidos pelo hipotálamo como por exemplo, a vasopressina, a ocitocina e o peptídeo natriurético atrial.

Desta forma, pode-se prever que qualquer mau funcionamento dos sistemas de regulação da pressão pode levar a doenças do sistema cardiovascular e evoluir para a falência de órgãos vitais como os rins, coração e áreas do encéfalo, no caso de acidente vascular cerebral. A hipertensão essencial é uma das doenças mais comuns relacionadas a disfunções do controle cardiovascular, no entanto os fatores desencadeadores desta patologia são ainda pouco conhecidos, mas bastante urgentes uma vez que 20 a 30\% da população brasileira é hipertensa, chegando a 50\% nas idades mais avançadas (SBH, 2005).

Levantamentos da Sociedade Brasileira de Hipertensão (2005) alertam ainda que dos casos de hipertensão somente $10 \%$ são considerados de origem secundária, o restante possui origem desconhecida, a chamada hipertensão essencial. 
O sistema nervoso central possui papel importante no desenvolvimento e manutenção da hipertensão arterial, uma vez que após a dessensibilização dos baro e quimiorreceptores, os centros vasomotores do encéfalo passam a ignorar que a pressão não esteja nos níveis considerados normais. Além disso, a estimulação simpática crônica também é um importante agente no desenvolvimento da patologia. Como exemplo da importância da estimulação simpática para o desenvolvimento da hipertensão tem-se os ratos espontaneamente hipertensos que têm reconhecidamente a hiperatividade simpática como um dos fatores desencadeantes da patologia. O controle da pressão arterial pelo sistema nervoso central, a influência de drogas sobre este mecanismo e a importância da nicotina para o desenvolvimento da hipertensão serão abordados com detalhes nos capítulos seguintes.

\subsection{O controle da pressão arterial pelo sistema nervoso central.}

O núcleo do trato solitário (NTS) é uma região chave para a regulação da pressão arterial. Localizado na porção dorsomedial do bulbo, o NTS possui importantes funções integrativas especialmente das informações cardiovasculares (REIS et al., 1984; VAN GIERSBERGEN et al., 1992). Este núcleo recebe aferências primárias dos baro- e quimiorreceptores localizados no arco aórtico e no seio carotídeo, o que possibilita ajustes instantâneos dos níveis de pressão arterial.

A partir desta primeira sinapse, as eferências do NTS informam diversos outros núcleos encefálicos sobre a necessidade de controle das oscilações da pressão arterial compondo a resposta final.

Dentre estes núcleos encontra-se a medula oblonga ventrolateral que se divide em porções caudal (CVLM) e rostral (RVLM). Do NTS partem eferências excitatórias, predominantemente glutamatérgicas, para a CVLM a qual se projeta para a RVLM inibindo-a através principalmente da liberação de 
GABA (DAMPNEY, 1994), um neurotransmissor com funções predominantemente inibitórias. A medula oblonga ventrolateral rostral (RVLM) é um importante núcleo relacionado ao controle da pressão arterial já que modula diretamente os neurônios pré-ganglionares simpáticos da coluna intermediolateral da medula espinhal de acordo com os ajustes homeostáticos necessários (AMENDT et al., 1979; BLESSING et al., 1981; DAMPNEY, 1981; DAMPNEY et al., 1982).

O sistema nervoso autônomo parassimpático também é modulado a partir das informações provenientes dos barorreceptores para o NTS. Deste núcleo partem projeções para o núcleo motor dorsal do nervo vago (localizado imediatamente abaixo do NTS) que, juntamente com o núcleo ambíguo (na porção ventrolateral do bulbo, acima da RVLM) compõem o nervo vago que é o mais abrangente dos nervos responsável, dentre outras coisas, pela diminuição da freqüência cardíaca, pois inerva diretamente o nodo sinoatrial (Figura 1).

A título de exemplificação, no caso de aumento da pressão arterial, o glutamato liberado pelos terminais dos barorreceptores no NTS irá estimular a inibição da CVLM que, através de aumento na liberação do GABA, diminuirá o tônus da RVLM sobre o sistema nervoso simpático, resultando em diminuição do simpático quando se tem aumento da pressão. Por outro lado, o sistema nervoso parassimpático, especialmente o nervo vago, será estimulado e promoverá diminuição da freqüência cardíaca para reverter o aumento de pressão detectado pelos barorreceptores. Este é o mecanismo compensatório reflexo, chamado convencionalmente de barorreflexo, que ocorre quando se tem somente a ação de núcleos bulbares controlando a pressão arterial. A figura 1 ilustra didaticamente este reflexo. 


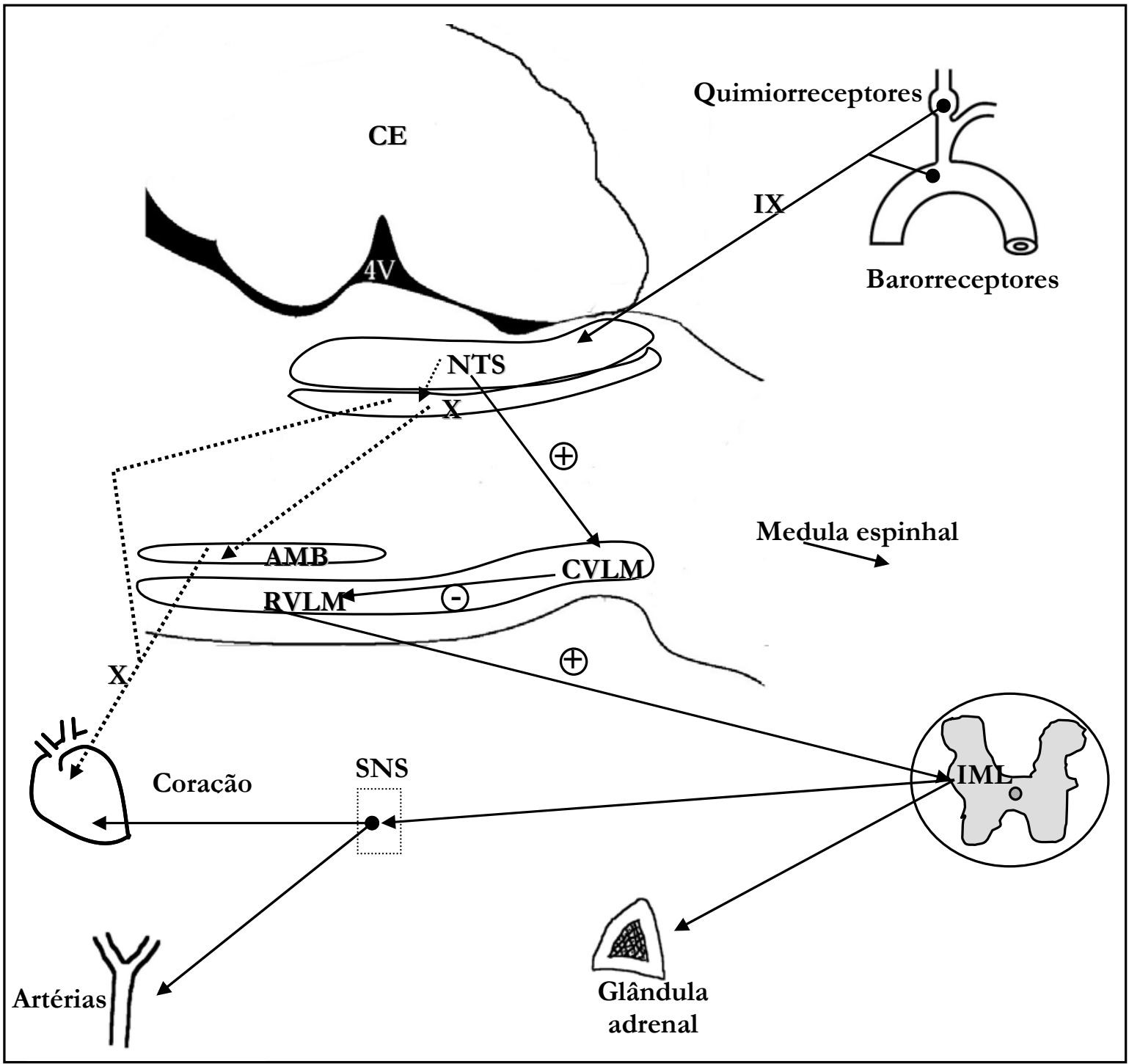

FIGURA 1. Esquema ilustrativo do barorreflexo. Corte longitudinal do bulbo de rato ilustrando os núcleos envolvidos no controle reflexo da pressão arterial, a interrelação entre eles e as projeções modulatórias do sistema nervoso autônomo simpático (linha contínua) e parassimpático (linha tracejada). A explicação detalhada encontra-se no texto. Abreviaturas: AMB: núcleo ambíguo; CE: cerebelo; CVLM: medula ventrolateral caudal; IML: coluna intermediolateral da medula espinhal; NTS: núcleo do trato solitário; RVLM: medula ventrolateral rostral; SNS: cadeia de gânglios do sistema nervoso simpático; IX: nervo glossofaríngeo; $\mathrm{X}$ : nervo vago; $4 \mathrm{~V}$ : quarto ventrículo. Modificado de Ross e cols. (1985). 
Ressalta-se que, nem sempre que houver aumento da pressão arterial, haverá conseqüentemente sua diminuição, haja vista quando há necessidade de aumento do aporte sangüíneo para os músculos no caso clássico de luta e fuga, reações de alerta ou durante o exercício físico. Nesses casos, os núcleos bulbares de controle da pressão arterial são modulados por áreas hipotalâmicas e corticais como o núcleo central da amígdala (SAHA et al., 2005). (Figura 2).

Como mencionado anteriormente, o bulbo não age sozinho no controle da pressão arterial, mas em conjunto com diversas outras regiões. Por exemplo, o NTS envia e recebe projeções do locus coeruleus (LC), localizado na região dorsal da ponte, neste núcleo localiza-se o maior grupamento de células noradrenérgicas do encéfalo (A6), o que colabora para a modulação da atividade simpática através da medula ventrolateral já descrita.

O núcleo paraventricular do hipotálamo (PVN) também é um importante centro controlador da pressão arterial. Os neurônios deste núcleo recebem e enviam projeções para o NTS (ONAI et al., 1987; HARDY, 2001), além de modular diretamente o sistema nervoso autônomo através de projeções para a VLM (HARDY, 2001) e para os neurônios pré-ganglionares simpáticos da medula espinhal (SwANSON \& SAWCHENKO, 1980; BLESSING et al., 1982a; KENNEY et al., 2003). Além disso, o PVN é o maior centro produtor de vasopressina (SWAAB et al., 1975) que é armazenada na porção neural da hipófise e secretada na corrente sangüínea promovendo ações pressoras bem conhecidas (MCNEILL, 1983; ENGELMANN et al., 2004). A produção e liberação de ocitocina, do peptídeo natriurético atrial e do hormônio adreno-córticotrófico (ACTH) também é regulada pelo PVN (ENGELMANN et al., 2004).

A modulação da pressão arterial vai além de somente a inter-relação entre os núcleos encefálicos. A vasta gama de neurotransmissores e seus moduladores envolvidos nesta regulação permite o ajuste preciso da pressão sangüínea pelo NTS. 
O NTS apresenta grande diversidade de neurotransmissores e seus receptores. Neste núcleo podem ser encontrados mais de 21 diferentes tipos de neurotransmissores (PALKOVITS, 1985), os quais podem interagir entre si (FIOR et al., 1994; YANG et al., 1994a; FIOR \& FUXE, 1995) aumentando ainda mais a complexidade neuroquímica das ações por ele mediadas. 


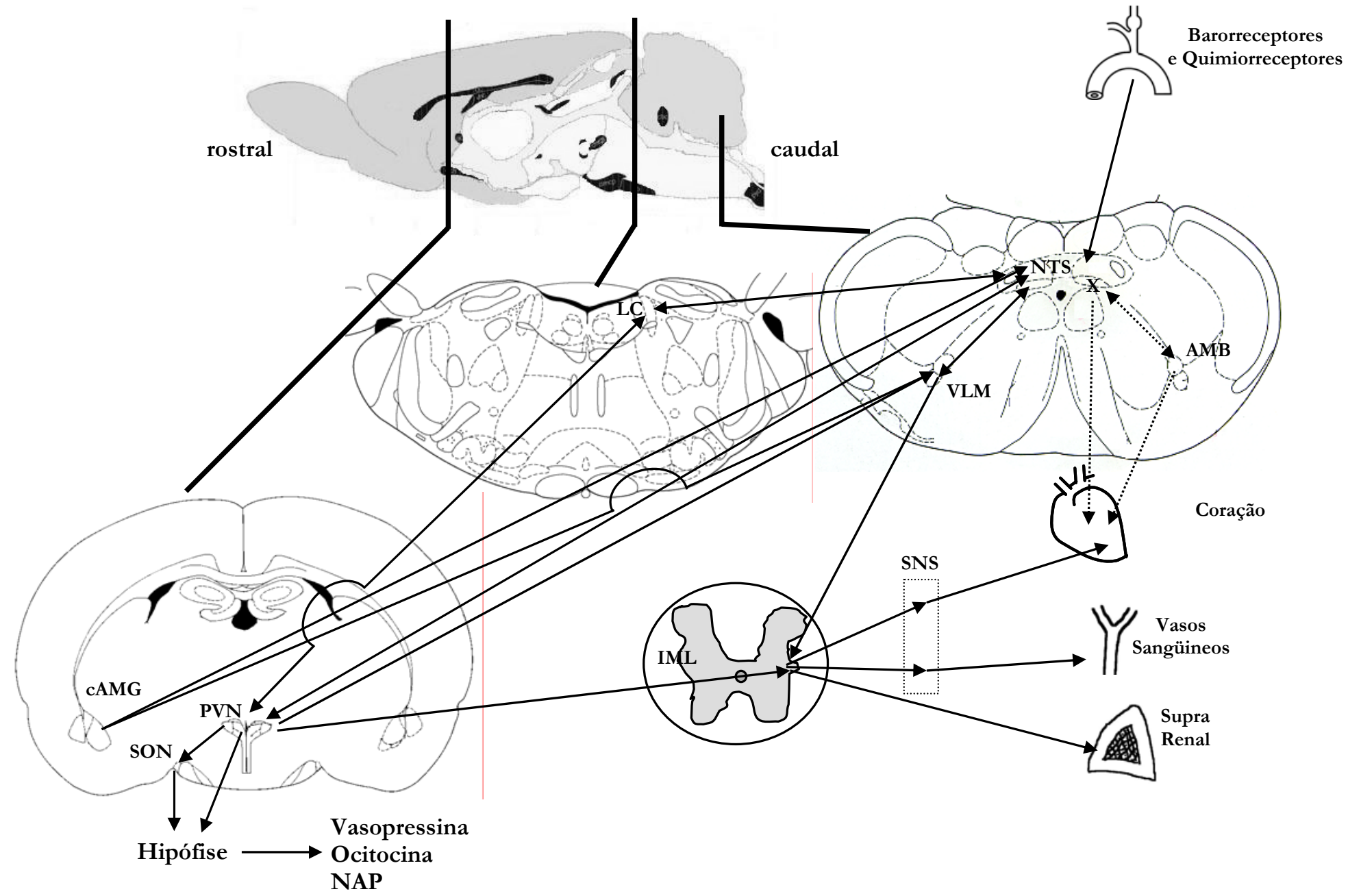

FIGURA 2. Esquema ilustrativo resumido do controle cardiovascular pelo sistema nervoso central. A imagem acima mostra uma secção longitudinal do encéfalo de rato e a localização aproximada das regiões responsáveis pelo controle da pressão arterial, que estão representadas em cortes transversais. A explicação detalhada deste controle encontra-se no texto. Abreviaturas: cAMG: núcleo central da amígdala; IML: coluna intermediolateral da medula espinhal; LC: locus coeruleus; NAP: peptídeo natriurético atrial; NTS: núcleo do trato solitário; PVN: núcleo paraventricular do hipotálamo; SNS: sistema nervoso simpático; SON: núcleo supra óptico; VLM: medula oblonga ventrolateral. Imagens do encéfalo de rato adaptadas de PAXINOS \& WATSON (1986). 


\subsection{O sistema catecolaminérgico e o controle central da pressão} arterial.

As catecolaminas são importantes neurotransmissores envolvidos no controle central da pressão arterial. No sistema nervoso central, especialmente nos núcleos responsáveis pelo controle central da pressão arterial, podem-se encontrar grandes grupamentos celulares predominantemente catecolaminérgicos.

O LC, por exemplo, é o maior grupamento noradrenérgico do encéfalo, denominado A6 (DAhLSTROEM \& FUXE, 1964). No NTS encontram-se os grupamentos A2 e C2, noradrenérgico e adrenérgico, respectivamente. A medula ventrolateral caudal possui grande quantidade de neurônios noradrenérgicos (grupamento A1) e na porção rostral da medula ventrolateral encontram-se muitas células adrenérgicas do grupamento C1 (DAHLSTROEM \& FUXE, 1964).

As catecolaminas são formadas a partir da tirosina que é convertida a LDOPA através da enzima tirosina hidroxilase. A dopamina é a primeira catecolamina formada na cadeia de síntese através da Dopa descarboxilase. A dopamina $\beta$-hidroxilase $(\mathrm{DBH})$ converte e dopamina em noradrenalina que é o substrato da enzima feniletanolamina n- metiltransferase (PNMT) para a formação da adrenalina (Figura 3).

É bem conhecido que injeção de noradrenalina no NTS ou nos ventrículos cerebrais promove queda na pressão arterial e na freqüência cardíaca (DE JONG, 1974; STRUYKER-BOUdier et al., 1975; KuBO \& MisU, 1981). No PVN, a injeção de noradrenalina ou a liberação do transmissor através das projeções do LC produz aumento na pressão arterial (HARLAND et al., 1989; HWANG et al., 1998), através de mecanismos envolvendo a estimulação da angiotensina II (UsHigOME et al., 2002) e possivelmente a liberação de vasopressina (VELTMAR et al., 1992). 
A noradrenalina exerce seus efeitos através de receptores pertencentes à grande familia de receptores com 7 domínios transmembrânicos acoplados a proteína G. Seu principal receptor no sistema nervoso central, relacionado ao controle da pressão arterial, é o do subtipo $\alpha_{2}$-adrenérgico que tem propriedades inibitórias sobre a produção de AMP cíclico intracelular (Gi) (AANTAA et al., 1995).

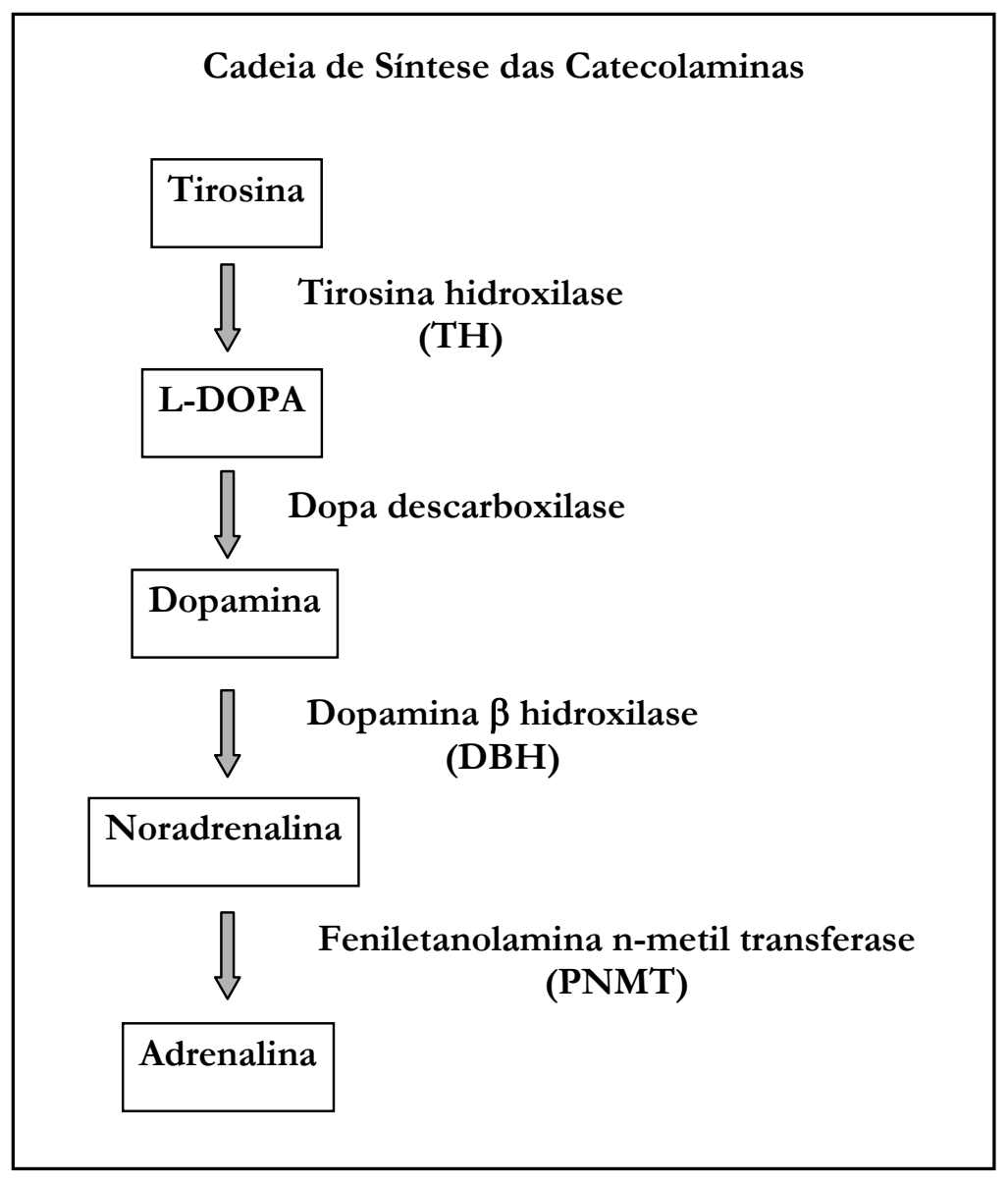

FIGURA 3. Esquema da cadeia de síntese das catecolaminas. O aminoácido tirosina é convertido a L-DOPA através da enzima tirosina hidroxilase, a Dopa descarboxilase converte a L-DOPA a dopamina que é o substrato da enzima DBH para formação da noradrenalina, e finalmente através da PNMT a noradrenalina é transformada em adrenalina. 


\subsection{O neuropeptídeo Y e o controle central da pressão arterial.}

O Neuropeptídeo Y (NPY), descrito por TATEMOTO e colaboradores (1982), possui 36 aminoácidos e é um dos neuropeptídeos mais abundantes no sistema nervoso central de mamíferos e mais amplamente distribuído (SILVA et al., 2005). O NPY possui um receptor denominado Y, também com 7 domínios transmembrânicos, acoplado a proteína $G i$ ou à $G_{0}$, que se divide em subtipos de Y1 a Y6 (BraIn \& Cox, 2006). No entanto os principais responsáveis pelas ações cardiovasculares deste peptídeo no sistema nervoso central são os receptores Y1 e Y2 que possuem ações antagônicas: o Y1 promove queda e o Y2 aumenta a pressão arterial quando ativados nas regiões de controle cardiovascular (NARVAEZ et al., 1993; YANG et al., 1993). O NPY possui forte ação modulatória sobre o sistema catecolaminérgico.

A neuromodulação envolvendo a noradrenalina e o NPY é bem caracterizada nas áreas envolvidas no controle central do sistema cardiovascular (YANG et al., 1994b; FIOR-CHADI \& FUXE, 1998). A interação entre os receptores $\alpha 2$-adrenérgicos, da noradrenalina, e o Y1 e Y2 de NPY foi descrito há bastante tempo. Existe uma relação antagonística entre os receptores $\mathrm{Y} 1$ e $\alpha_{2}$-adrenérgico uma vez que a estimulação do receptor de NPY promove queda na afinidade do receptor da noradrenalina (YANG et al., 1994a). Já a ativação dos receptores Y2 potencializa o efeito da noradrenalina sobre os receptores $\alpha_{2}$-adrenérgicos no locus coeruleus (ILLES et al., 1993).

\subsection{O sistema glutamatérgico e o controle central da pressão} arterial.

O glutamato possui papel fundamental no controle da pressão arterial pelo sistema nervoso central (DAMPNEY et al., 2003), além de ser o principal neurotransmissor das aferências dos baro e quimiorreceptores no NTS (TALMAN et al., 1980; MACHADO, 2001). 
Sua síntese e degradação é compartimentalizada entre neurônios e células gliais. No sistema nervoso central, a glutamina é liberada pelo astrócito e captada pelo neurônio pré-sináptico onde é convertida a glutamato pela enzima glutaminase, o qual é liberado na fenda sináptica. A oferta deste transmissor na fenda sináptica é controlada pelas células gliais, especificamente, os astrócitos, que captam o glutamato e o reciclam através de incorporação de um grupo amina $\left(\mathrm{NH}_{3}\right.$ ) voltando a ser disponibilizado (DAIKHIN \& YUDKOFF, 2000) (Figura 4).

A administração deste aminoácido nas áreas responsáveis pelo controle central da pressão arterial promove alterações na pressão arterial. No NTS e no LC o glutamato exerce ações depressoras (TALMAN et al., 1981; HARFSTRAND et al., 1986; SVED \& FELSTEN, 1987; MURASE et al., 1993), no PVN o aminoácido promove aumento na pressão arterial (MARTIN \& HAYWOOD, 1992; GOREN et al., 2000). O glutamato possui ações pressoras quando administrado na RVLM (MAEDA et al., 1991) e depressoras quando na CVLM (ARNOLDA et al., 1992).

As ações cardiovasculares do glutamato podem ser mediadas por receptores metabotrópicos (acoplados a proteína $\mathrm{G}$ ) e ionotrópicos (associados a canais iônicos). Estes últimos são subdivididos em três categorias de acordo com agonistas exógenos: N-Methyl-D-Aspartato (NMDA), ácido 2-amino-3hidroxi-5-metil-4-isoxasole-propiônico (AMPA) e kainato (KA). Todos os receptores ionotrópicos do glutamato são seletivos para $\mathrm{Na}^{+}$e $\mathrm{Ca}^{2+}$ (revisto por KEW \& KEMP, 2005). 


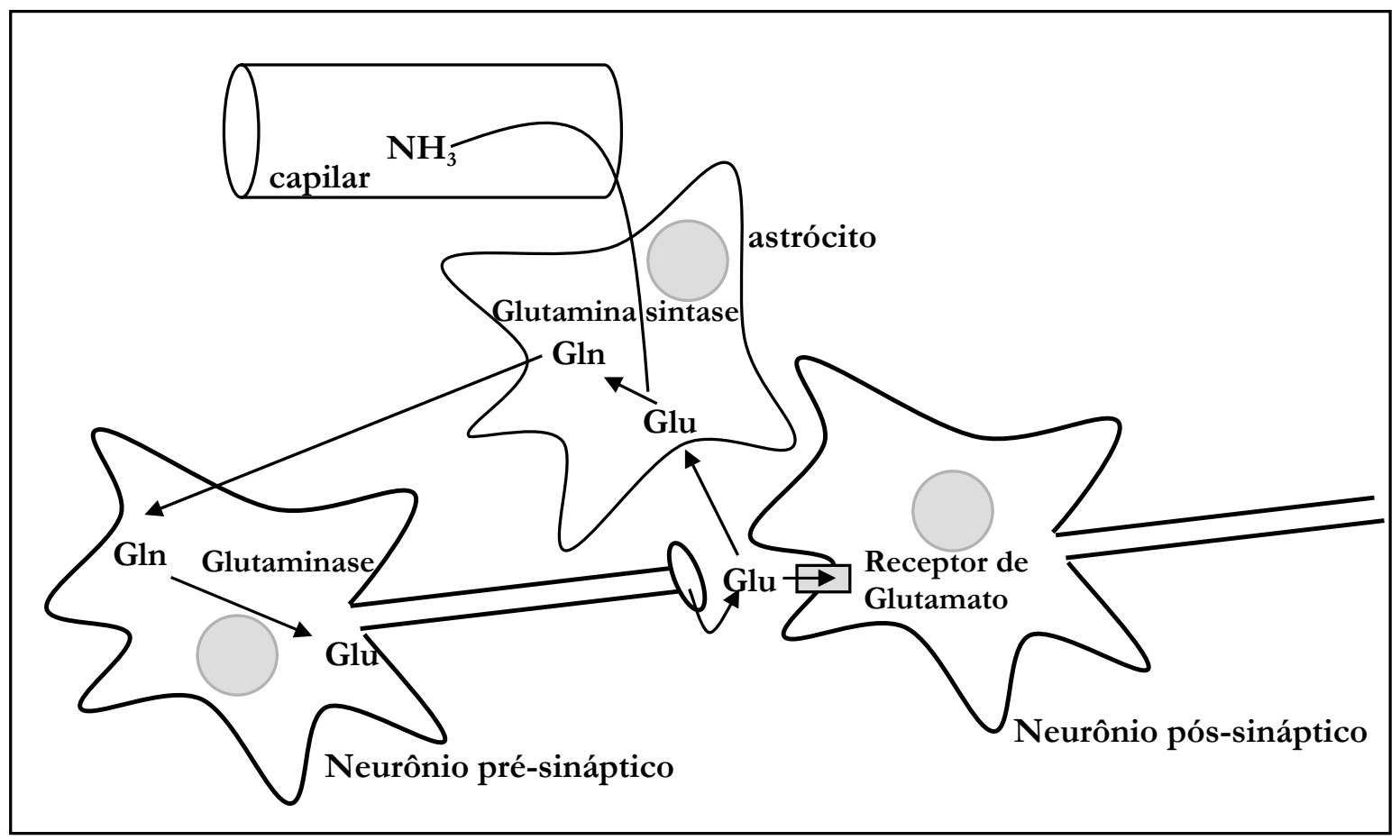

FIGURA 4. Esquema da síntese e degradação do glutamato ilustrando a compartimentalização do sistema. Abreviaturas: Glu: glutamato, Gln: glutamina; $\mathrm{NH}_{3}$ : grupo amina. Modificado de DAIKHIN e YUdKOFF (2000).

\subsection{O sistema angiotensinérgico e o controle central da pressão} arterial.

O sistema angiotensinérgico está presente no sangue e em tecidos como o coração e o sistema nervoso central. $\mathrm{Na}$ figura 5 tem-se o esquema do sistema angiotensinérgico extraído de FERREIRA e SANTOS (2005), ilustrando a formação dos peptídeos e seus receptores. 


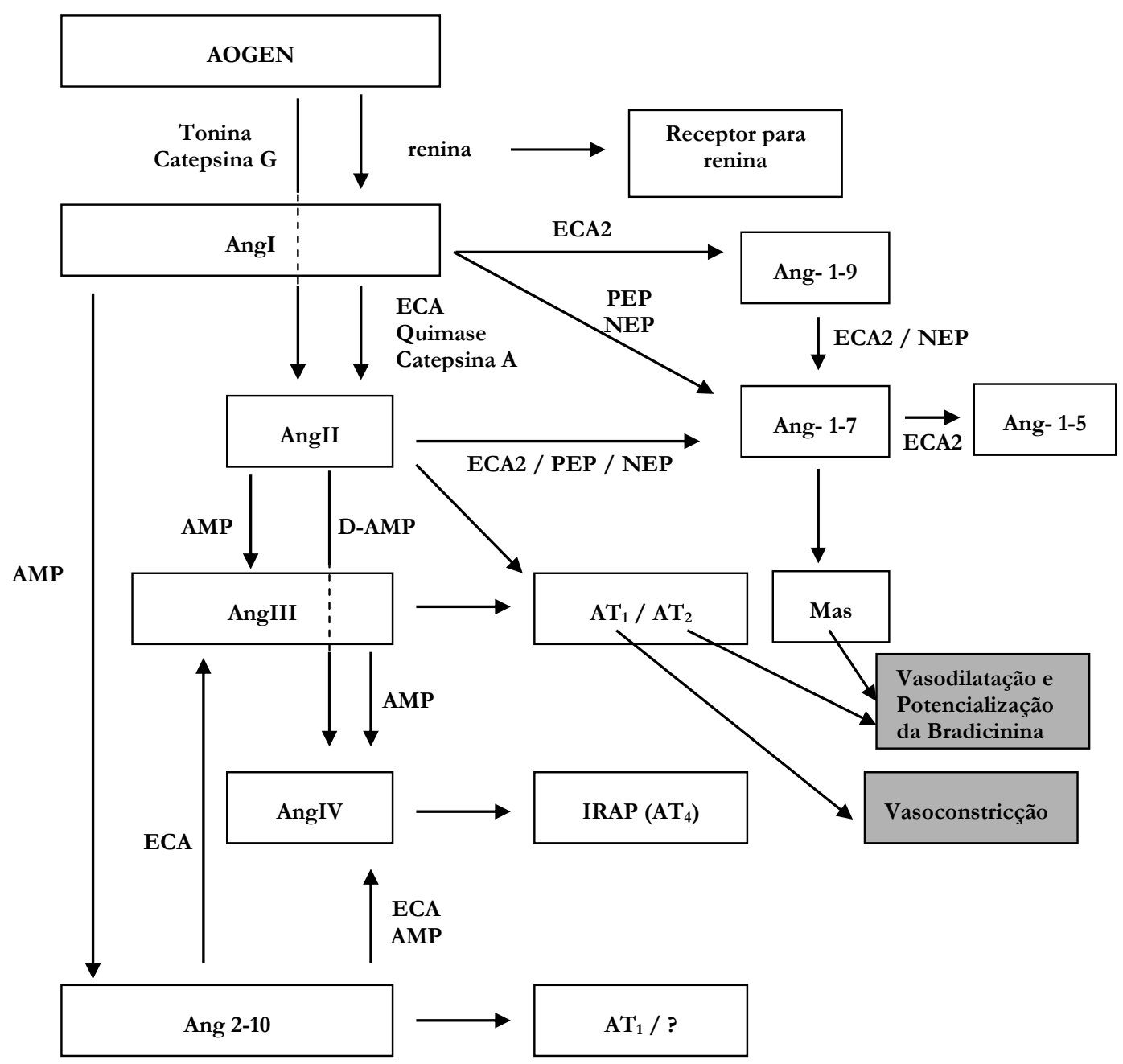

FIGURA 5. Esquema do sistema renina-angiotensina ilustrando a formação dos peptídeos, seus receptores e a ação cardiovascular ( $\mathrm{AT}_{1}, \mathrm{AT}_{2}$ e Mas), ainda não há evidências da participação dos demais receptores no controle cardiovascular. Abreviaturas: AOGEN: angiotensinogênio, AMP: aminopeptidase, ANG: angiotensina, $\mathrm{AT}_{1}$ : receptor tipo 1 de angiotensina II, $\mathrm{AT}_{2}$ : receptor tipo 2 de angiotensina II, $\mathrm{AT}_{4}$ : receptor tipo 4 de angiotensina IV, D-AMP: dipeptidil-aminopeptidase, ECA: enzima conversora de angiotensina, IRAP: aminopeptidase regulada por insulina, Mas: receptor de angiotensina 1-7, PCP: prolil-carboxipeptidase, PEP: prolil-endopeptidase, NEP: endopeptidase neutra. Modificado de FERREIRA e SANTOS (2005). 
No sangue, a renina secretada pelas células justaglomerulares renais transformam o angiotensinogênio (produzido no fígado e liberado na corrente sangüínea) em angiotensina I que é convertida a angiotensina II, agente vasoconstritor, pela enzima conversora de angiotensina (ECA, produzida nos pulmões). Através da enzima conversora de angiotensina tipo 2 (ECA2), a angiotensina II é convertida a angiotensina 1-7 (DONOGHUE et al., 2000), que promove vasodilatação e diminuição da pressão arterial (FERREIRA \& SANTOS, 2005).

Todos os componentes deste sistema também podem ser encontrados no sistema nervoso central (FISHMAN et al., 1981; MCKINLEY et al., 2003) onde a angiotensina atua como um importante neurotransmissor nos núcleos responsáveis pelo controle cardiovascular. A proposta mais atualizada da formação de angiotensina II no sistema nervoso central está ilustrada na figura 6. LAVOIE e Sigmund (2003) propuseram 2 mecanismos, denominados autócrino e parácrino, para a formação de angiotensina II. No primeiro, a angiotensina II é gerada intracelularmente nos neurônios a partir do angiotensinogênio, renina e enzima conversora de angiotensina produzidos por estas células. O mecanismo parácrino é aquele em que há liberação para o meio extracelular do angiotensinogênio pelos astrócitos, que são os maiores produtores desta molécula no sistema nervoso central (STORNETTA et al., 1988) e de renina pelos neurônios. A angiotensina II seria formada a partir da clivagem extracelular do angiotensinogênio e da angiotensina I (LAVOIE \& SIGMUND, 2003), que interagiria com as células vizinhas exercendo sua função. 


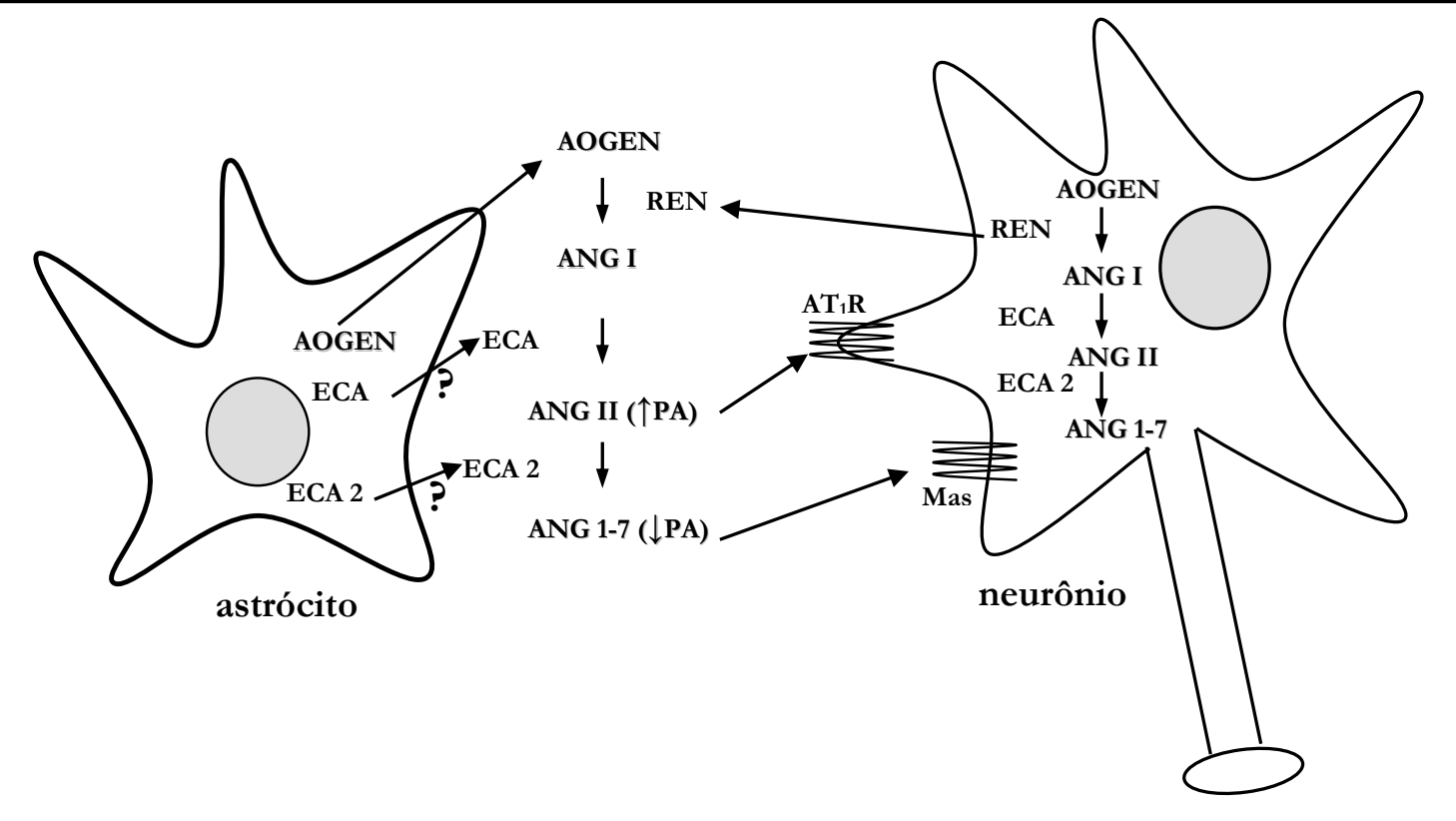

FIGURA 6. Esquema do sistema renina-angiotensina no sistema nervoso central. A explicação detalhada encontra-se no texto. As interrogações indicam incerteza sobre a etapa. Abreviaturas: AOGEN: angiotensinogênio, ANG: angiotensina, $\mathrm{AT}_{1} \mathrm{R}$ : receptor tipo 1 de angiotensina II, ECA: enzima conversora de angiotensina, Mas: receptor de angiotensina 1-7. Baseado em Lavoie e Sigmund (2003), McKinley e colaboradores (2003), SAntos e colaboradores (2003) e WARNER e colaboradores (2004).

No sistema nervoso central, a angiotensina II eleva a pressão arterial quando microinjetada no NTS (CASTO \& PHILlips, 1984, 1985) devido à inibição do barorreflexo (CASTO \& PHILLIPS, 1986). Na VLM, o peptídeo parece exercer um efeito depressor sobre a CVLM e pressor na RVLM (MURATANi et al., 1993). BAHNER e colaboradores (1995) mostraram que a angiotensina II também promove aumento da pressão arterial quando injetada diretamente no PVN através de inibição do peptídeo natriurético atrial. Sabe-se que a angiotensina II modula inclusive a liberação de vasopressina promovendo aumento da pressão arterial quando administrada no PVN (STECKELINGS et al., 1992; HATAE et al., 2001). 
A angiotensina II modula ainda outros sistemas de neurotransmissão como o do NPY e o vasopressinérgico. O efeito pressor do NPY sobre os receptores Y2 é potencializado e a diminuição da pressão, quando da ativação dos receptores Y1, é antagonizada pela angiotensina II (DIAZ-CABIALE et al., 2003).

Além disso, a atividade exagerada do sistema renina-angiotensina no sistema nervoso central está relacionada ao desenvolvimento da hipertensão em ratos espontaneamente (SHR, Dahl) e experimentalmente hipertensos (DOCA e renovascular) (POCHIERO et al., 1983; YONGUE et al., 1991; LARK \& WEYHENMEYER, 1992; NishimURA et al., 1992; MURATANI et al., 1993).

As ações da angiotensina II sobre o controle cardiovascular se dão através da interação do peptídeo com receptores denominados $\mathrm{AT}_{1}$ e $\mathrm{AT}_{2}$. Estes receptores possuem 7 domínios transmembrânicos e ativam a cascata intracelular através da proteína $\mathrm{Gq}\left(\mathrm{AT}_{1} \mathrm{R}\right)$ ou Gi $\left(\mathrm{AT}_{2} \mathrm{R}\right)$ (DZIMIRI, 2002). Como já mencionado, a ação hipertensora da angiotensina II dá-se através da interação do peptídeo com receptores $\mathrm{AT}_{1}$, e esta é a resposta predominantemente encontrada quando da injeção do peptídeo em animais adultos uma vez que a quantidade de receptores $\mathrm{AT}_{2}$ diminui na medida em que o desenvolvimento termina, chegando a quase escassez na vida adulta (TSUTSUmi \& SAAVEDRA, 1991; NuYT et al., 1999; SAAVEDRA, 2005).

Além da angiotensina II, outro peptídeo do sistema renina-angiotensina participa da regulação central da pressão arterial: a angiotensina 1-7. SILVA e colaboradores (1993) demonstraram que a Ang1-7 promove queda na pressão arterial quando microinjetada na porção caudal da medula oblonga ventrolateral. Por outro lado, na RVLM a Ang1-7 promove um significante aumento na pressão arterial média, comparado aos efeitos da angiotensina II (SIlva et al., 1993; Fontes et al., 1994; SANTOS \& CAMPAGNOLE-SANTOS, 1994). A exemplo da angiotensina II, a angiotensina 1-7 também possui um importante efeito estimulatório sobre a liberação de vasopressina pelos 
neurônios do PVN (SANTOS \& CAMPAGNOLE-SANTOS, 1994). Já sobre o NTS, a angiotensina 1-7 promove efeitos antagônicos aos da angiotensina II, promovendo queda na pressão arterial (CAMPAGNOLE-SANTOS et al., 1989) através, dentre outros mecanismos, do aumento da sensibilidade do barorreflexo (CAMPAGNOLE-SANTOS et al., 1992). Tanto no sistema nervoso central quanto nos rins e nas artérias, as ações da angiotensina 1-7 são mediadas pelos receptores acoplados à proteína $G$ denominados Mas (SANTOS et al., 2003).

\subsection{O sistema colinérgico e o controle central da pressão arterial.}

O sistema colinérgico também colabora no mecanismo de controle da pressão arterial pelo sistema nervoso central. Este sistema parece estar diretamente envolvido na gênese da hipertensão em ratos SHR (HOFFMAN et al., 1978; GiUliano \& BREZENOFF, 1987), já que quando há inibição do sistema colinérgico nas áreas encefálicas envolvidas no controle cardiovascular em SHRs pré-hipertensos o aparecimento da hipertensão pode ser retardado (GIUliano \& BreZENOFF, 1987; VARGAS \& BreZENOFF, 1988) ou os níveis de hipertensão desses ratos diminuem quando adultos (BREZENOFF \& CAPUTI, 1980). Da mesma forma, injeção de acetilcolina intracerebroventricularmente promove aumento da liberação de vasopressina (IITAKE et al., 1986) levando a aumento da pressão arterial (BREZENOFF, 1984; IITAKE et al., 1986).

A acetilcolina é formada a partir da colina e da acetil Coa através da enzima colina-acetiltransferase (ChAT) e age via receptores chamados muscarínicos que são acoplados à proteína $G$, e nicotínicos que formam um canal iônico composto de 5 subunidades (Figura 7). 


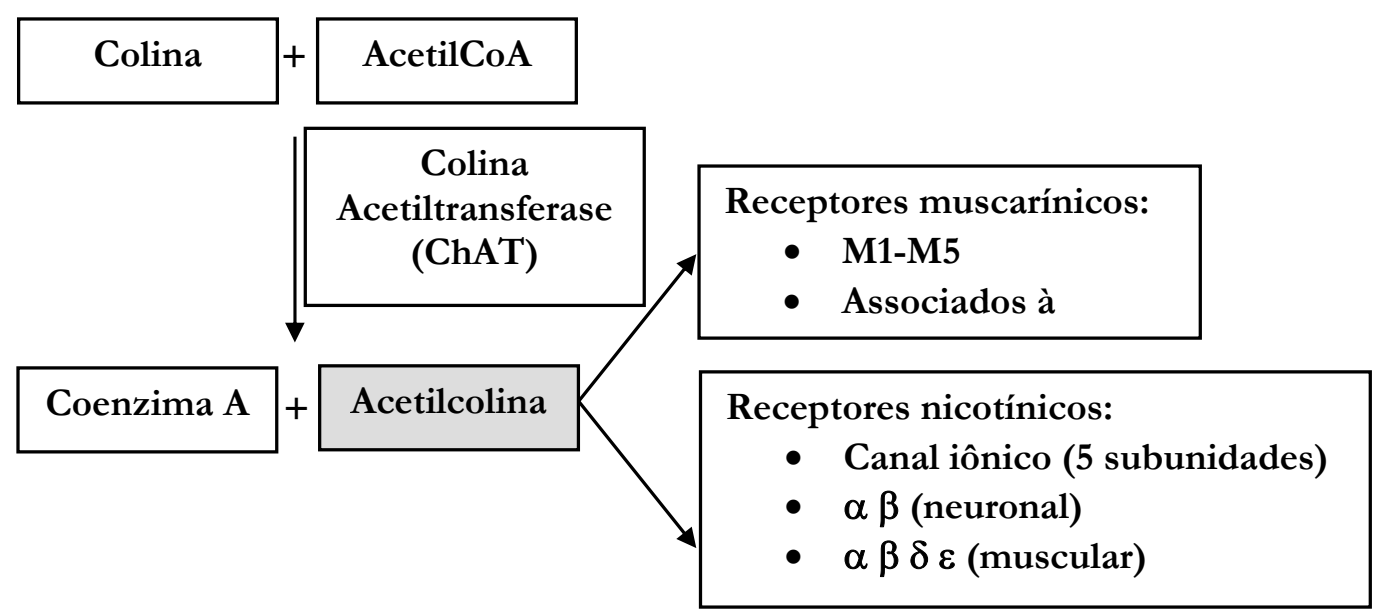

FIGURA7. Esquema da síntese da acetilcolina e seus receptores. A colina acetiltransferase sintetiza a acetilcolina a partir da colina e do acetilCoa. Os receptores para a acetilcolina são divididos em muscarínicos e nicotínicos de acordo com os agonistas exógenos, muscarina e nicotina respectivamente.

O sistema angiotensinérgico está intimamente relacionado ao colinérgico nas áreas do sistema nervoso central responsáveis pelo controle cardiovascular. Como já foi mencionado, os ratos SHR possuem hiperatividade do sistema angiotensinérgico, inclusive no hipotálamo. KUBO e colaboradores (2002) completaram este raciocínio ao demonstrarem que a ativação do PVN, pela angiotensina II, promove excitação da RVLM via transmissão colinérgica resultando em um efeito pressórico.

A acetilcolina é importante também para a diminuição da pressão arterial através da modulação da freqüência cardíaca pelo nervo vago. $O$ núcleo motor dorsal do vago juntamente com o núcleo ambíguo formam este nervo que modula diretamente a freqüência cardíaca através da liberação de acetilcolina no nodo sinoatrial.

Apesar das ações cardiovaculares da acetilcolina estarem relacionadas tanto à ativação de receptores muscarínicos quanto nicotínicos nos núcleos encefálicos que controlam a pressão (BHARGAVA et al., 1978; BrEZENOFF, 
1984; FERREIRA et al., 2000), a ação especial da nicotina sobre o desenvolvimento da hipertensão é uma questão de saúde pública uma vez que o abuso desta droga pode levar a conseqüências cardiovasculares importantes, como o desenvolvimento da hipertensão. Assim, as ações da nicotina sobre controle cardiovascular serão abordadas detalhadamente a seguir.

\subsection{A ação da nicotina sobre a pressão arterial.}

Os efeitos cardiovasculares decorrentes do tabagismo são, em sua grande maioria, resultados da ação da nicotina, um alcalóide presente em espécimes vegetais da família das Solanáceas, especialmente as Nicotiana sp. Dentre estas encontra-se o tabaco, Nicotiana tabacum L., cujas folhas servem como matéria prima na fabricação de cigarros e charutos. Desde que isolado pela primeira vez, em 1828, este alcalóide vem sendo extensivamente estudado devido a seus efeitos fisiológicos e farmacológicos como agonista dos receptores da molécula endógena acetilcolina.

Os efeitos periféricos da nicotina variam de fraqueza e transpiração até dores de cabeça, tontura, vômito, diarréia, salivação intensa e oscilação da pressão sangüínea e freqüência cardíaca (MCBRIDE et al., 1998). LU e CREAGER (2004), em sua revisão, reforçaram a importância do tabagismo como o principal fator de risco para doenças cardiovasculares em geral.

No sistema vascular, pequenas doses de nicotina promovem vasoconstricção periférica (HENNINGFIELD et al., 1985) podendo explicar, em parte, o aumento da pressão arterial observado durante o ato de fumar (BENOWITZ, 1992). Além disso, a nicotina potencializa as ações do sistema nervoso simpático, o que causa aumento dos níveis plasmáticos de adrenalina e noradrenalina (WESTFALL \& WATTS, 1964; CRYER et al., 1976; SIESS et al., 1982; MANCIA et al., 1990). 
Grande parte das ações cardiovasculares da nicotina está associada a concentrações elevadas de catecolaminas no plasma decorrentes da estimulação da neurotransmissão simpática. A nicotina pode agir basicamente de três formas para ativação do sistema nervoso autonômico simpático: 1) diretamente sobre o sistema nervoso central; 2) estimulando a transmissão no gânglio simpático, o que pode implicar em aumento da atividade do nervo pósganglionar simpático; e 3) estimulando diretamente a liberação de catecolaminas pelas terminações nervosas das fibras simpáticas e pela medula da glândula adrenal (KRUGER et al., 1995). A ênfase será dada aos efeitos da nicotina sobre o sistema nervoso central.

A nicotina é capaz de atravessar a barreira hematoencefálica interagindo com o sistema nervoso central quase que instantaneamente após administração intravascular (BHAGAT, 1970). Neste caso, liga-se a receptores nicotínicos de acetilcolina em várias regiões encefálicas como hipotálamo, hipocampo, mesencéfalo e bulbo (CLARKE et al., 1985; LONDON et al., 1985) induzindo estimulação neurohumoral e modulação da neurotransmissão noradrenérgica, dopaminérgica, vasopressinérgica, glutamatérgica e do neuropeptídeo Y (NPY) (BAlfour, 1982; Chesselet, 1984; Ashworth-Preece et al., 1998). Dentre as áreas citadas como centros de ação da acetilcolina, algumas têm papel muito relevante no controle e modulação central da pressão arterial como já foi visto.

Quando injetada no NTS ou na CVLM, a nicotina promove hipotensão e bradicardia (KUBO \& MiSU, 1981; CRISCIONE et al., 1983; ABERGER et al., 2001). Por outro lado, quando administrada na RVLM e na área postrema, a nicotina causa aumento dose-dependente na pressão arterial (SAPRU, 1987; ROBERTSON et al., 1988), sendo que estes efeitos podem ser abolidos pelo bloqueio local dos receptores nicotínicos (TSENG et al., 1994; DHAR et al., 2000).

No sistema nervoso central, as ações da nicotina podem ser mediadas pelos dois subtipos de receptores nicotínicos de acetilcolina: os heteroméricos, 
formados por conjuntos de duas subunidades alfa $\left(\alpha_{2}-\alpha_{6}\right)$ e três beta $\left(\beta_{2}-\beta_{4}\right)$; e os homoméricos formados por cinco subunidades alfa $\left(\alpha_{7-9}\right)$. Desta forma, há um enorme espectro de conformações possíveis para os receptores nicotínicos e que gera grande diversidade de respostas possíveis (DANI, 2001).

DAHR e cols. (2000) mostraram que, no NTS, predominam os receptores $\alpha 3 \beta 4$, já que injeções de drogas específicas que bloqueiam esses receptores (hexametônio, mecamilamina ou $\alpha$-conotoxina AuIB) reduzem de 47 a $79 \%$ a resposta hipotensora provocada pela microinjeção de nicotina. O bloqueio dos receptores $\alpha 7$ pela $\alpha$-bungarotoxina ou $\alpha$-conotoxina ImI, no entanto, reduz a resposta da nicotina em aproximadamente 30\% (DHAR et al., 2000).

Os receptores nicotínicos de acetilcolina formam um canal iônico seletivo para o $\mathrm{Na}^{+}$mas também permeável ao $\mathrm{Ca}^{2+}$ (revisto por HOGG e cols., 2003), esta facilitação de entrada do Ca2+ é mais pronunciada nos receptores $\alpha 7$ onde a nicotina pode atuar facilitando a liberação de neurotransmissores através da mobilização dependente de cálcio das vesículas (NEFF et al., 1998; GRILLI et al., 2005; BARIK \& WONNACOTT, 2006).

A nicotina pode atuar também sobre a célula alvo modulando a sinalização neuronal (DAJAs-BAILADOR \& WONNACOTT, 2004) e regulando a expressão de alguns genes como da dopamina (SEROVA \& SABBAN, 2002), NPY (MATTA et al., 1997) tirosina hidroxilase (LI et al., 2000; SuN et al., 2004), e de genes de expressão primária como o c-fos e c-jun (GREENBERG et al., 1986; VALENTINE et al., 1996; SALMINEN et al., 1999).

A ação da nicotina parece ser diferencial entre as raças de ratos, já que os geneticamente hipertensos (SHR) são mais sensíveis aos efeitos deste alcalóide no que se refere às alterações na pressão arterial, do que os normotensos Wistar Kyoto (WKY) (TSENG et al., 1994). No NTS, a hipotensão e bradicardia apresentadas após a injeção local única de nicotina são 
mais acentuadas em SHR do que em WKY, assim como a resposta hipertensora e taquicárdica observada após administração do alcalóide na área postrema e RVLM de SHR (TSENG et al., 1994).

Além disso, Bui e cols. (1994) demonstraram que o tratamento com nicotina antecipa o desenvolvimento da hipertensão em ratos com fator genético à patologia, além de intensificar a hipertensão gerada.

Além de suas ações farmacológicas diretas, tem sido observado que a nicotina é capaz de modular outros sistemas de neurotransmissão.

Sabe-se, por exemplo, que a nicotina é um potente estimulador da síntese de hormônio adreno-córtico trófico (ACTH). Esta estimulação, no entanto, se dá via ativação de neurônios catecolaminérgicos dos grupamentos noradrenérgico A2 e adrenérgico C2 localizados no NTS (MATTA et al., 1997). Foi verificado que esses neurônios catecolaminérgicos são ativados não só em decorrência da administração local de nicotina, mas também após administração sistêmica do alcalóide (MATTA et al., 1997). Além disso, os neurônios destas mesmas áreas, que sintetizam o NPY, também foram ativados após administração de nicotina (MATTA et al., 1997), mostrando o envolvimento deste sistema de neurotransmissão no bulbo mediando a liberação de ACTH pela hipófise. Ainda com relação ao NPY, foi observado aumento na quantidade do seu RNAm e proteína no hipotálamo após administração sistêmica de nicotina (MATTA et al., 1997) o que foi relacionado às disfunções na ingestão alimentar desencadeadas pelo tabagismo.

A ativação do sistema glutamatérgico pela nicotina também é relatada, inclusive associando esta interação ao controle cardiovascular (ASHWORTHPREECE et al., 1997). Foi verificado que a administração de nicotina no NTS aumenta em 150\% os níveis basais de glutamato no NTS, sugerindo modulação do barorreflexo pelo alcalóide (ASHWORTH-PREECE et al., 1998). Dentre os diversos neurotransmissores envolvidos no controle cardiovascular, 
e que possuem sua liberação e regulação pós-sináptica moduladas pela nicotina, o glutamato é um dos mais estudados (NEFF et al., 1998).

Não só as áreas medulares são ativadas pela nicotina administrada sistemicamente, mas também o PVN, sendo que neste núcleo o alcalóide induz a liberação de vasopressina (OTA et al., 1992; MATTA et al., 1993).

Sobre o LC, a nicotina promove aumento da transcrição do RNA mensageiro da tirosina hidroxilase (MITCHELL et al., 1993) e na atividade da enzima (SMITH et al., 1991) resultando em aumento da liberação de noradrenalina (MITCHELL et al., 1993). A ação da nicotina sobre os mecanismos pós-transcricionais das catecolaminas também foi descrito no LC (SUN et al., 2004).

Como discutido anteriormente, já é descrita a capacidade da nicotina em modular diversos sistemas de neurotransmissão, bem como a importância funcional destas interações. No entanto, com exceção do glutamato, nenhuma das interações observadas para o alcalóide foi relacionada ao controle cardiovascular.

Portanto, considerando que a nicotina: 1) antecipa o aparecimento da hipertensão em animais com predisposição genética para esta patologia, 2) atua nas áreas envolvidas no controle central do sistema cardiovascular, 3) pode, eventualmente, exercer essas ações através da ativação de outros sistemas de neurotransmissão classicamente conhecidos por modularem o sistema cardiovascular. E, ainda, a inexistência na literatura de trabalhos que revelem a real participação da nicotina periférica no sistema nervoso central, particularmente nas áreas envolvidas com o controle cardiovascular, propõe-se uma análise celular dos sistemas colinérgico, catecolaminérgico, angiotensinérgico, glutamatérgico e do NPY, nas áreas centrais responsáveis pelo controle cardiovascular após a administração periférica de nicotina em ratos espontaneamente hipertensos e WKY, normotensos. 
OBJETIVOS 


\section{OBJETIVOS GERAIS}

Avaliar a influência do tratamento crônico com nicotina sobre o desenvolvimento da hipertensão nos ratos com predisposição genética à patologia, bem como a neurotransmissão nas áreas encefálicas envolvidas no controle cardiovascular em ratos geneticamente hipertensos e normotensos.

\section{OBJETIVOs EsPeCíficos}

1) Avaliar a ação do tratamento crônico com nicotina sobre a pressão arterial e freqüência cardíaca dos ratos espontaneamente hipertensos e nomotensos.

2) Avaliar o sistema catecolaminérgico, estudando a expressão da enzima tirosina hidroxilase no NTS, VLM, LC e PVN após administração periférica crônica $(60$ dias $)$ de nicotina através das técnicas de imunohistoquímica e hibridização in situ, bem como pela análise dos receptores adrenérgicos do subtipo $\alpha_{2}$ pela radioautografia quantitativa e hibridização in situ.

3) Avaliar o sistema do NPY no NTS, VLM, LC e PVN após administração periférica crônica de nicotina através das técnicas de imunohistoquímica e hibridização in situ, bem como analisar os receptores $\mathrm{Y}$ através da radioautografia.

4) Avaliar o sistema glutamatérgico através da análise do RNAm da glutaminase pela técnica de hibridização in situ, bem como dos receptores NMDA, AMPA e Kainato através da radioautografia quantitativa, no NTS, VLM, LC e PVN tratamento periférico crônico com nicotina.

5) Avaliar o sistema colinérgico no NTS, núcleo motor dorsal do vago e ambíguo após administração periférica de nicotina por 60 dias, através da análise da proteína e RNAm da colina-acetiltransferase pela imunohistoquímica 
e hibridização in situ, respectivamente, e análise do RNAm dos receptores nicotínicos, através da hibridização in situ, no NTS, LC e PVN.

6) Avaliar o sistema angiotensinérgico no NTS, LC e PVN após administração periférica crônica de nicotina através da análise do RNAm do angiotensinogênio pelo método da hibridização in situ, bem como análise dos receptores da Angiotensina II pela radioautografia quantitativa.

7) Analisar a interação da nicotina com o sistema angiotensinérgico in vitro, em cultura de células do tronco encefálico e do hipotálamo de ratos espontaneamente hipertensos e normotensos. 
MATERIAL E MÉTODO 


\section{Material e Método}

\subsection{Animais}

Foram utilizados ratos (Rattus norvegicus albinus) machos das linhagens SHR, com predisposição genética à hipertensão, e Wistar Kyoto (WKY), normotensos, provenientes do biotério do Departamento de Fisiologia do Instituto de Biociências da Universidade de São Paulo. Os animais foram mantidos em número de três indivíduos da mesma linhagem por gaiola recebendo ração apropriada e água sem restrição. As normas éticas institucionais e internacionais para experimentos envolvendo animais foram respeitadas em todas as etapas deste estudo. O número amostral foi de 6 animais por grupo experimental.

\subsection{Tratamento com Nicotina}

Os ratos foram submetidos ao tratamento crônico com nicotina ou placebo na forma de pastilhas (Innovative Research of America, Toledo, Ohio) implantadas subcutaneamente na região lateral do pescoço.

Inicialmente, os ratos com 1 mês de idade receberam pastilhas de $10 \mathrm{mg}$ de nicotina com duração de 21 dias (liberação de $75 \mu \mathrm{g}$ de nicotina por hora), as quais foram substituídas por de 100mg que duram 60 dias, permanecendo deste modo até completarem 8 semanas de tratamento.

Todos os ratos foram pesados semanalmente a fim de identificar possíveis alterações neste parâmetro causadas pela ação da nicotina. 


\subsection{Registro indireto da pressão arterial e freqüência cardíaca}

A pressão arterial e freqüência cardíaca também foram monitoradas semanalmente através de pletismografia de cauda computadorizada (IITC Inc., modelo 31, Califórnia, USA).

Os ratos foram mantidos em câmara aquecida a $28 \pm 1^{\circ} \mathrm{C}$ por aproximadamente 15 minutos dentro de gaiolas individuais. Após este período os ratos foram transferidos para um contensor de acrílico para aferição da pressão arterial e freqüência cardíaca. A média de 6 tomadas por rato foi considerada na comparação semanal entre os grupos nicotina e placebo.

\subsection{Quantificação da concentração plasmática de nicotina e} cotinina

A quantificação da concentração plasmática de nicotina e de seu principal metabólito, a cotinina, foi realizada através de cromatografia líquida de alta eficiência (HPLC) cujo método foi adaptado do desenvolvido por HARIHARAN e colaboradores (1988) e NAKAJIMA e cols. (2000).

O princípio básico do HPLC de fase reversa é a retenção, pela coluna de separação, das moléculas hidrofóbicas e sua eluição por soluções contendo solventes como o metanol. Dependendo do grau de hidrofobicidade a substância irá se descolar da coluna mais ou menos facilmente, se a substância for menos hidrofóbica irá eluir rapidamente, ou seja seu tempo de retenção é baixo. Por outro lado, se a substância for mais hidrofóbica sua interação com a coluna é mais forte e será mais difícil sua eluição; com isso, o tempo de retenção será maior. A partir do momento da eluição, as substâncias passam por um detector, neste caso a luz ultravioleta, que envia um sinal para o computador formando os picos referentes às moléculas eluídas.

Para tanto, amostras de sangue foram retiradas através de punção da veia caudal de cada animal e submetidas à análise por HPLC (Shimadzu) e 
detecção por UV (256nm, Shimadzu), utilizando-se coluna Supelco Hypersil ODS $5 \mu \mathrm{m} 25 \mathrm{~cm} \times 4,6 \mathrm{~mm}$ em forno (Shimadzu) a $35^{\circ} \mathrm{C}$ e fluxo de $1,5 \mathrm{~mL} / \mathrm{min}$ da fase móvel para separação dos componentes a serem analisados.

O sangue ( $1 \mathrm{~mL}$ por rato) foi coletado com escalpes e seringas heparinizados e individualizados. As amostras foram transferidas para microtubos de centrífuga contendo 40 U.I. de heparina sódica (Liquemine, Roche) e submetidas a centrifugação $(4500 \mathrm{rpm})$ durante 15 minutos a $4^{\circ} \mathrm{C}$. O plasma, aproximadamente $500 \mu \mathrm{L}$, foi separado para um novo tubo e armazenado a $-80^{\circ} \mathrm{C}$ até seu processamento.

Antes da determinação plasmática de nicotina e cotinina, calibrou-se o aparelho com uma solução padrão formada por 10ng de nicotina (Sigma), cotinina (Sigma) e acetanilida (Merck) em fase móvel constituída de 30mM de citrato (Merck), 30mM de Na2HPO4 (Merck), 1mM de ácido heptano 1sulfônico (Merck), 10\% acetonitrila (OmniSolv, Merck), trietilamina (Merck), para ajustar o $\mathrm{pH}$ em 5,7, e filtrada em membrana de 0,2 $\mathrm{mm}$ de poro (Millipore).

A partir da área dos picos de absorbância gerados pelos padrões, calculou-se a porcentagem de extração destas drogas no plasma de rato não tratado.

Para isso, adicionaram-se, em $200 \mu \mathrm{L}$ de plasma de rato não tratado, nicotina, cotinina e acetanilida em concentrações conhecidas (10ng de cada, como o procedimento descrito para o padrão), $200 \mu \mathrm{L}$ de uma solução $5 \mathrm{M}$ de $\mathrm{NaOH}$ (Merck) e 1M de $\mathrm{NaCl}$ (Merck), e $700 \mu \mathrm{L}$ de diclorometano (Merck); após agitar em vortex durante 1 minuto, os tubos foram centrifugados a 12000 rpm por 5 minutos a $4^{\circ} \mathrm{C}$. Adicionaram-se mais $700 \mu \mathrm{L}$ de diclorometano a cada tubo que foram agitados em vortex por mais 1 minuto e centrifugados como anteriormente descrito. A fase contendo o diclorometano foi transferida para um novo tubo que foi colocado em liofilizador (DNA120 SpeedVac, 
Thermo Savant), durante aproximadamente 25 minutos, até a completa evaporação do solvente orgânico. As drogas concentradas foram suspensas em $120 \mu \mathrm{L}$ de fase móvel, sendo que $100 \mu \mathrm{L}$ foram injetados no aparelho para análise por HPLC.

As concentrações de nicotina e cotinina no plasma de ratos com as pastilhas implantadas foram determinadas como descrito acima para o cálculo da porcentagem de extração; no entanto, sem adição de nicotina ou cotinina. A área do pico do padrão interno, acetanilida, serviu como parâmetro para o cálculo da porcentagem de extração da nicotina e cotinina do plasma dos ratos já que a concentração desta droga era conhecida. Cada animal teve a concentração de nicotina e cotinina determinadas em triplicata.

O método foi validado através da construção de curvas de calibração para os três componentes a serem analisados (nicotina, cotinina e acetanilida). Para isso, 5 concentrações destas substâncias foram submetidas à quantificação por HPLC : 2,5; 5; 10; 50 e 100ng. Cada uma das concentrações foi quantificada em triplicata, a média aritmética das áreas dos picos foi considerada para a construção das curvas de calibração. Cada curva de calibração foi construída através da plotagem da média das áreas dos picos referentes a cada concentração de cada droga no eixo das ordenadas, pela respectiva concentração no eixo das abscissas. A correlação linear foi calculada para cada uma das curvas.

\subsection{Imunohistoquímica}

O método imunohistoquímico foi descrito com detalhes por CHADI e colaboradores $(1993 ; 1994)$.

Oito semanas após o implante das pastilhas de nicotina ou placebo os ratos foram anestesiados profundamente com pentobarbital sódico (Hypnol $3 \%$, Fontoveter) e submetidos a uma perfusão transcardíaca de solução salina 
( $\mathrm{NaCl}$ 0,9\%) seguida de solução fixadora (ZAMBONI \& DE MARTINO, 1967) contendo paraformaldeído (Merck) a 4\% e ácido pícrico saturado (Sigma) diluídos em tampão fosfato $(0,1 \mathrm{M}, \mathrm{pH} 7,4)$. Os encéfalos foram removidos e pós-fixados nesta mesma solução por 90 minutos sendo, a seguir, mantidos em solução de sacarose (Synth) (10\%) dissolvida em tampão fosfato (0,1M; pH 7,4) por 48 horas, sendo renovada a cada 24 horas. Após este período, os encéfalos foram congelados em isopentano (Sigma) à $-35^{\circ} \mathrm{C}$ em gelo seco. Cortes seriados frontais com espessura de $14 \mu \mathrm{m}$ foram obtidos em criostato (Leica, modelo CM3050, Alemanha), à temperatura de $-25^{\circ} \mathrm{C}$, da região da medula oblonga objetivando o NTS, a VLM, o ambíguo e o núcleo motor dorsal do vago; da ponte para o LC, e do prosencéfalo objetivando o PVN (FIGURA 8), os quais foram montados em lâminas previamente gelatinizadas, preparo necessário para a técnica imunohistoquímica.

As secções foram então incubadas a $4^{\circ} \mathrm{C}$ com os anticorpos primários contra TH (Protos Biotech, coelho, 1:400, durante 24h), NPY (Sigma, coelho, 1:2000, durante 24h), Glutamato (Sigma, coelho, 1:2000, por 24h) e ChAT (Chemicon, cabra, 1:250, durante 72h). Depois de lavadas em tampão fosfato, as secções foram incubadas com imunoglobulinas biotiniladas anti-coelho ou cabra (Vector, EUA, 1:230) por 1 hora diluídas em tampão fosfato $(0,1 \mathrm{M}, \mathrm{pH}$ $7,4)$ contendo Triton X-100 (0,3\%, Sigma) e albumina de soro bovino (BSA, 1\%, Sigma). Numa terceira incubação, a avidina e uma peroxidase biotinilada (Vectastain, Vector, EUA) foram introduzidas, ambas diluídas 1:120, durante 45 minutos. A reação foi completada na presença de 3-3'-diaminobenzidina tetrahidrocloreto (DAB, Sigma) como cromógeno em tampão tris- $\mathrm{HCl}$ pH 7,4 e $\mathrm{H}_{2} \mathrm{O}_{2}$ (Fluka, Suíça) como substrato para a enzima peroxidase presente no tecido, durante 6 minutos. Os procedimentos imunohistoquímicos foram uniformizados considerando o ponto de saturação do $\mathrm{DAB}$, a diluição do anticorpo primário longe da saturação e um tempo de incubação ajustado de 
tal modo que os elementos mais escuros das secções encefálicas estivessem inferiores à saturação (ZOLI et al., 1990).

Os perfis imunorreativos foram analisados e quantificados em microscópio acoplado a um sistema de análise microdensitométrica de imagens (Zeiss) pertencente ao Laboratório de Neurologia Experimental da Faculdade de Medicina da Universidade de São Paulo sob responsabilidade do Prof. Dr. Gerson Chadi.

Para a análise microdensitométrica, foi adotada a medida da lâmina sem secção como fixa em 200 unidades arbitrárias. O valor do fundo (inespecífico) de cada secção foi registrado, assim como o valor da marcação de cada núcleo (valor específico adicionado do inespecífico) adquirido através de uma máscara, manipulada pelo pesquisador, que visa cobrir os perfis considerados específicos.O cálculo da densidade específica da imunorreatividade foi feito subtraindo-se o valor médio adquirido em cada núcleo do valor médio inespecífico para o grupo controle e para o experimental obtendo-se, desta forma, o valor específico da marcação (spMGV, do inglês specifc mean gray value) de cada neurotransmissor em cada núcleo. A área ocupada pelas imunorreatividades $\left(\mu \mathrm{m}^{2}\right)$ também foi analisada utilizando-se como parâmetro a mesma máscara feita para o estudo da densidade da marcação.

De modo geral e simplificado, o spMGV indica a concentração do transmissor nas células e a área refere-se à quantidade de células produzindo o transmissor. Desta forma, pode haver alteração na intensidade (spMGV) sem alteração na área ocupada e vice-versa.

Os perfis considerados específicos cuja marcação estava muito próxima à coloração do fundo inespecífico não foram considerados na análise da densidade ou da área ocupada pela marcação. 


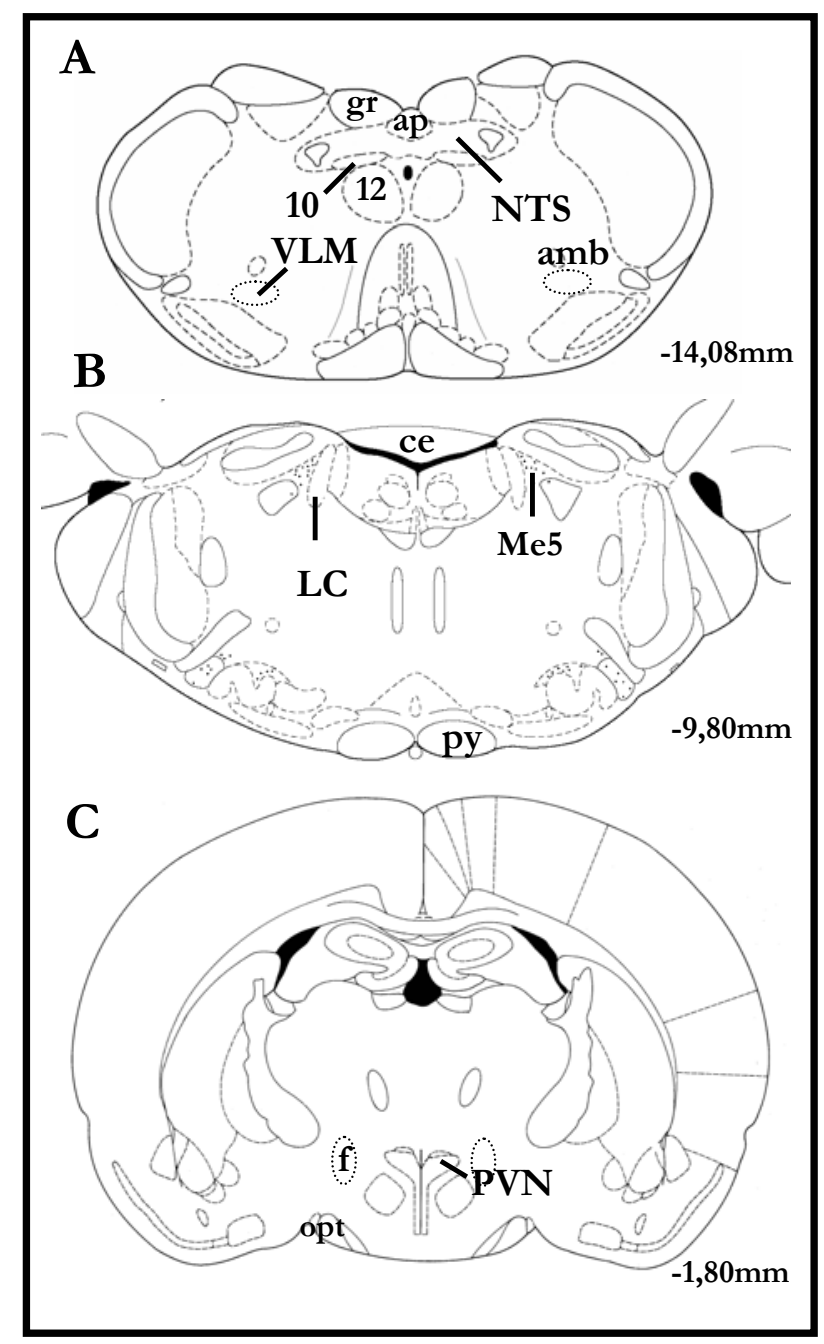

FIGURA 8. Esquemas ilustrando a posição anatômica do núcleo do trato solitário (NTS), núcleo motor dorsal do vago (10), medula oblonga ventrolateral (VLM), núcleo ambíguo (amb) (A), locus coeruleus (LC) (B) e do núcleo paraventricular do hipotálamo (PVN) (C). Os valores em milímetros abaixo de cada figura referem-se à distância em relação ao bregma. Abreviaturas: $10=$ núcleo motor dorsal do vago; $12=$ núcleo hipoglosso, $\mathrm{amb}=$ núcleo ambíguo, $\mathrm{ap}=$ área postrema, $\mathrm{ce}=$ cerebelo, $\mathrm{f}=$ fornix, $\mathrm{gr}=$ núcleo grácil, Me5=núcleo trigeminal mesencefálico, opt=trato óptico, py=trato piramidal. 


\subsection{Hibridização in situ}

O método de hibridização in situ empregado foi descrito com detalhes por ERDTMANN-VOURLIOTIS e colaboradores (1999).

Após oito semanas de tratamento os ratos foram decapitados e os encéfalos rapidamente removidos e congelados em isopentano (Sigma) e gelo seco a uma temperatura de $-35^{\circ} \mathrm{C}$ ficando armazenado a $-80^{\circ} \mathrm{C}$ até seu processamento. Secções frontais com $14 \mu \mathrm{m}$ de espessura foram obtidas do NTS, VLM, LC e PVN em criostato a $-24^{\circ} \mathrm{C}$, montadas em lâminas de vidro previamente cobertas com poli l-lisina (Sigma), pré-hibridizadas e armazenadas em freezer a $-80^{\circ} \mathrm{C}$ até a utilização. Todos os procedimentos foram realizados em condições ideais de assepsia, com uso de luvas e materiais esterilizados evitando, assim, a presença de RNAses no material.

Antes de iniciar o tratamento das secções fez-se o preparo do material necessário para a hibridização in situ. Toda a vidraria, espátulas de pesagem e afins foram esterilizados em forno apropriado a $180^{\circ} \mathrm{C}$ durante no mínimo 8 horas. Ponteiras, tubos e demais materiais de polietileno, assim como as soluções necessárias para a pré-hibridização, hibridização e lavagem foram devidamente autoclavados por 45 minutos à $120^{\circ} \mathrm{C}$ para esterilização.

$\mathrm{Na}$ pré-hibridização as secções foram submetidas à fixação com paraformaldeído (Merck) diluído a 4\% em tampão fosfato à $4^{\circ} \mathrm{C}$ durante 30 minutos, lavadas em 3x PBS por 5 minutos à temperatura ambiente e em 1x PBS também por 5 minutos e desidratadas em uma série de álcoois 70, 90 e 100\%. Uma vez finalizada a pré-hibridização as lâminas contendo as secções de tecido foram armazenadas em freezer a $-80^{\circ} \mathrm{C}$ até serem submetidas à hibridização.

As sondas de oligonucleotídeos (Invitrogen, Life Technologies, EUA) utilizadas foram sintetizadas de acordo com a seqüência escolhida após pesquisa bibliográfica onde se obteve uma seqüência de bases que melhor 
identifica os RNAm de interesse nos núcleos aqui estudados. As sondas de cDNA possuem as seguintes seqüências de bases:

Receptor $\boldsymbol{\alpha}_{2 \mathrm{~A}}$-adrenérgico: de 648 a 695 (NICHOLAS et al., 1993).

Angiotensinogênio: de 314 a 323 (RIFTINA et al., 1995).

NPY: de 3146 a 3194 (PIERIBONE et al., 1992).

TH: de 1351 a 1398 (GRIMA et al., 1985; SHORES et al., 1999).

Glutaminase: de 931 a 960 (NAJLERAHIM et al., 1990).

ChAT: de 109 a 153 (ISHII et al., 1990; KAYADJANIAN et al., 1999).

Receptor nicotínico - Subunidade $\boldsymbol{\alpha}_{3}$ : de 138 a 183 (FERRARI et al., 1999).

Receptor nicotínico - Subunidade $\boldsymbol{\beta}_{4}$ : de 1020 a 1065 (FERRARI et al., 1999).

Receptor nicotínico - Subunidade $\boldsymbol{\alpha}_{7}$ : de 1144 a 1189 (FERRARI et al., 1999).

As sondas foram marcadas radiativamente através de incubação com uma solução contendo ${ }^{35} \mathrm{~S}$-ATP (Amersham Biosciences), a enzima terminal transferase (Amersham Biosciences), responsável pela ligação do ATP radioativo à sonda de oligonucleotídeo, e seu tampão específico (Amersham Biosciences). Após breve centrifugação, a solução permaneceu em incubação por 20 minutos a $37^{\circ} \mathrm{C}$. Após este período, adicionou-se tRNA de fungo (Gibco) e tampão TE ao oligonucleotídeo marcado. Para a extração da sonda purificada foram adicionados fenol, clorofórmio e álcool isoamílico na proporção 25:24:1 (USB). Os tubos contendo a sonda e os reagentes foram centrifugados por 5 minutos e o sobrenadante foi transferido para um novo tubo de polietileno, a este novo tubo foram adicionados $\mathrm{NaCl} 5 \mathrm{M}$ e álcool absoluto a $-20^{\circ} \mathrm{C}$. Esta solução ficou em freezer a $-80^{\circ} \mathrm{C}$ por 30 minutos sendo centrifugada a $11000 \mathrm{rpm}$ por mais 30 minutos. O precipitado consiste da amostra de oligonucleotídeo marcado e purificado, o qual foi diluído em tampão TE contendo ditiotreitol (DT'T, Sigma). Em seguida, a atividade (cpm) 
de uma amostra de $2 \mu \mathrm{l}$ da solução contendo a sonda de oligonucleotídeos marcada, em líquido de cintilação (Ecolite), foi mensurada em um contador de cintilação (Tri-carb 2100TR Liquid Scintilation Analyzer, Packard).

Foi feito um tampão contendo a sonda de cDNA complementar ao RNAm do tecido marcada radioativamente e substâncias que favorecem a hibridização da sonda com o RNAm de interesse ou que bloqueiam sítios inespecíficos. O tampão de hibridização é constituído de formamida (Sigma), RNAt de fungo (Life Tech), DNA de esperma de salmão (Amersham Biosciences), DTT (Sigma), solução de Denhardt (USB), dextran sulfato (Amersham Biosciences), HEPES (Sigma), cloreto de sódio (Merck) e EDTA (Sigma).

O tampão, juntamente com a sonda marcada na concentração ideal (7000cpm/ $/ \mu \mathrm{L})$, foi colocado sobre as secções que ficaram hibridizando em estufa durante 20 horas à $42^{\circ} \mathrm{C}$.

O controle da especificidade da marcação foi feito através do deslocamento da sonda radioativa pela adição da mesma sonda não marcada ao tampão de hibridização. A sonda de oligonucleotídeo não marcada foi adicionada numa concentração 100 vezes maior que aquela da marcada.

Para a lavagem das secções foram preparadas soluções de lavagem compostas de cloreto de sódio e citrato tri-sódico (SSC) em água com dietilpirocarbonato (DEPC) onde as lâminas permaneceram por 4 vezes de 15 minutos a $55^{\circ} \mathrm{C}$. Em seguida as secções foram lavadas em SSC à temperatura ambiente por 1 hora e desidratadas em etanol 70\% seguido de etanol 90\% e $100 \%$.

Depois de secas, as lâminas foram montadas em cassetes para radioautografia (Amersham Biosciences) e expostas a filme radiosensível (Biomax MR, Kodak) por 1 (angiotensinogênio), 4 (NPY, TH, receptor $\alpha_{2}$ adrenérgico e Glutaminase) ou 6 semanas (subunidades $\alpha_{3}, \beta_{4}$ e $\alpha_{7}$ dos 
receptores nicotínicos). Após este período, os cassetes foram abertos em câmara escura e os filmes retirados. A revelação do filme foi feita utilizando-se revelador e fixador GBX (Kodak) durante 5 e 10 minutos, respectivamente.

Os radioautogramas foram analisados utilizando-se um sistema de análise de imagem (Imaging Research Inc., Brock University, Canadá, modelo M4/SK/ALU). A determinação da graduação dos tons de cinza dos filmes radioautográficos, marcados pela radioatividade liberada das secções, foi obtida através de medidas densitométricas semiquantitativas bilaterais das áreas encefálicas de interesse. A intensidade de luz que atravessa o filme radioautográfico foi fixada em 200 unidades densitométricas, o valor da marcação do filme fora da secção (background) foi subtraído da marcação das áreas em questão nas secções hibridizadas com oligonucleotídeo marcado a fim de se obter o valor específico dos tons de cinza (BENFENATI et al., 1986).

As lâminas utilizadas para exposição ao filme radioautográfico, após a revelação do filme, foram expostas a emulsão fotográfica (LM-1, Amersham Biosciences) a fim de analisar a especificidade da marcação. O tempo de exposição foi o dobro da exposição ao filme radioautográfico tendo em vista o decaimento do ${ }^{35} \mathrm{~S}$.

Após a exposição, as lâminas foram reveladas em revelador D-19 (Kodak) por 5 minutos seguido de ácido acético 0,5\% (Synth) para interrupção da revelação (30 segundos) e fixador tiossulfato de sódio 30\% (Merck) durante 10 minutos, sendo lavadas em seguida por 15 minutos em água corrente.

\subsection{Análise da ligação}

Os encéfalos utilizados foram os mesmos disponíveis para a hibridização in situ. Cortes de $14 \mu \mathrm{m}$ de espessura foram retirados da região do NTS, VLM, LC e PVN em criostato à $-24^{\circ} \mathrm{C}$ e montados em lâminas 
previamente cobertas com gelatina (Merck) e cromalium (Merck). Os cortes sofreram então o processo de marcação.

Foi utilizada uma concentração próxima à constante de dissociação $\left(\mathrm{K}_{\mathrm{D}}\right)$ para a análise da ligação.

\section{Análise dos receptores alfa2-adrenérgicos}

A metodologia descrita previamente por FIOR e colaboradores (1994) e FIOR e FUXE (1995) foi adotada para análise dos receptores alfa2-adrenérgicos onde o tecido foi incubado com o ligante radioativo $\left[{ }^{3} \mathrm{H}\right] \mathrm{RX}-821002$ (67Ci/mmol, Amersham Biosciences) diluído em tampão fosfato 0,01M contendo $50 \mathrm{mM}$ de $\mathrm{KCl}$ (Merck) e $10 \mathrm{mM}$ de $\mathrm{MgCl}_{2}$ (Merck). Utilizou-se a concentração de $1,7 \mathrm{nM}$ do ligante radioativo para o experimento de análise da ligação. Tal concentração baseou-se em dados prévios do laboratório (dados não publicados).

O deslocamento do ligante radioativo foi feito com adição de fentolamina (Sigma), um agonista dos receptores $\alpha_{2}$-adrenérgicos, na concentração de $10 \mu \mathrm{M}$, para a análise da ligação não específica.

As secções ficaram incubando por 60 minutos à temperatura ambiente, sendo em seguida, lavadas com o mesmo tampão utilizado na incubação por 2 vezes de 5 minutos, imersas rapidamente em água destilada à $4^{\circ} \mathrm{C}$ e secas em câmara fria sob corrente de ar. Depois de secas, as lâminas contendo as secções do encéfalo e uma escala padrão de emissão de radioatividade foram expostas a filme radioautográfico sensível ao trício (Hyperfilm ${ }^{3} \mathrm{H}$, Amersham Biosciences) em um cassete por 8 semanas. 


\section{Análise dos receptores do NPY}

Os receptores do NPY foram marcados através da incubação do tecido encefálico com o ligante radioativo $\left[{ }^{125} \mathrm{I}\right.$ PYY (4000Ci/mmol, Amersham Biosciences) num tampão contendo HEPES (20mM, Sigma), NaCl (137mM, Merck), $\mathrm{KCl}$ (5,4 mM, Merck), $\mathrm{KH}_{2} \mathrm{PO}_{4}$ (0,44mM, Merck), $\mathrm{CaCl}_{2}$ (1,26mM, Merck), $\mathrm{MgSO}_{4}(0,81 \mathrm{mM}$, Merck), Bacitracina (0,1\%, Sigma) e BSA (0,3\%, Sigma). Desta incubação resulta a marcação total dos receptores de NPY. A concentração do $\left[{ }^{125}\right.$ TPYY para a análise da ligação foi de $0,25 \mathrm{nM}$ baseado em experimentos anteriores do laboratório (ALMEIDA et al., 2000).

A análise da ligação nos subtipos de receptores do NPY (Y1 e Y2) foi feita através do deslocamento do ligante radioativo por agonistas específicos. Para análise do Y2, subtraiu-se da marcação total a marcação resultante do deslocamento do ligante pelo agonista específico dos receptores Y2 (NPY 1336, 1mM, Peninsula). Da mesma forma, a análise dos receptores Y1 deu-se através da subtração da marcação resultante do deslocamento do ligante pelo agonista específico do Y1 (NPY [Leu ${ }^{31}-$ Pro $\left.^{34}\right], 10 \mathrm{mM}$, Peninsula), da marcação total.

Após a incubação, as secções foram lavadas 3 vezes de 2 minutos cada com trizma 50mM (pH 7,4), seguido por uma lavagem em água destilada por 30 segundos. Essas lâminas secaram à $4^{\circ} \mathrm{C}$ sob ventilação e foram expostas juntamente com uma escala padrão de emissão radioativa a filme radioautográfico (Biomax-MR, Kodak) por 3 dias.

\section{Análise dos receptores da Angiotensina II}

A metodologia para a análise da ligação dos receptores de angiotensina II foi descrita com detalhes por SAAVEDRA e cols. (1986).

A ligação dos receptores de angiotensina II foi analisada através da incubação de secções da medula oblonga, da ponte e do diencéfalo por 45 
minutos, à temperatura ambiente, com solução tampão de fosfato de sódio $10 \mathrm{mM}$ contendo $\mathrm{NaCl}$ (120mM, Merck), $\mathrm{Na}_{2}$ EDTA (5mM, Sigma), bacitracina (0,1M Sigma) juntamente com o ligante radioativo $\left[{ }^{125} \Pi \operatorname{Sar}^{1}\right.$,le $^{8}$ AngII (2000Ci/mmol, Amersham Biosciences), após pré-incubação por 30 minutos com tampão fosfato 0,2M. Utilizou-se a concentração de $0,3 \mathrm{nM}$ do ligante radioativo baseada em experimentos anteriores (ALMEIDA et al., 2000).

O deslocamento do ligante radioativo para análise da ligação inespecífica

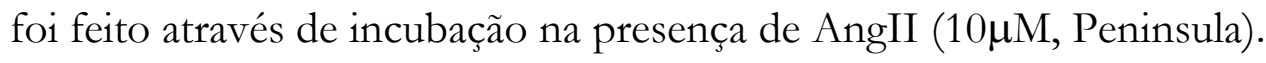

Em seguida as lâminas contendo as secções foram mergulhadas em água destilada gelada, banhadas por 2 vezes de 2 minutos em tampão fosfato $0,2 \mathrm{M}$ e novamente mergulhadas em água destilada gelada. As lâminas permaneceram sob ventilação à $4^{\circ} \mathrm{C}$ até a secagem completa para exposição a filme radioautográfico (Biomax-MR, Kodak) por 3 dias.

\section{Análise dos receptores ionotrópicos do Glutamato}

Os receptores do glutamato foram analisados de acordo com a técnica descrita por RAO e colaboradores (1997) com adaptações.

As secções do tecido foram pré-incubadas durante 90 minutos à $4^{\circ} \mathrm{C}$ em tampão TAB (tampão tris-acetato, pH 7,4, Merck) e secas sob ventilação antes da incubação com o ligante radioativo $\left[{ }^{3} \mathrm{H}\right]$ Glutamato $(51 \mathrm{Ci} / \mathrm{mmol}$, Amersham Biosciences), juntamente com ligantes frios específicos para os subtipos de receptores de glutamato, em TAB $50 \mathrm{mM}(\mathrm{pH} 7,4)$ por 30 minutos à $4^{\circ} \mathrm{C}$.

Para a marcação dos receptores NMDA foi utilizada solução contendo o $\left[{ }^{3} \mathrm{H}\right]$ Glutamato, $2,5 \mu \mathrm{M}$ de Quisqualato (específico para receptores AMPA, Sigma) e $1 \mu \mathrm{M}$ de ácido kaínico (específico para receptores de kainato, Sigma). 
Os receptores AMPA foram analisados através da incubação com $\left[{ }^{3} \mathrm{H}\right]$ Glutamato, $10 \mu \mathrm{M}$ de MK-801 (específico para receptores NMDA) e $1 \mu \mathrm{M}$ de ácido kaínico.

A análise dos receptores de kainato deu-se através de incubação com $\left[{ }^{3} \mathrm{H}\right]$ Glutamato, $10 \mu \mathrm{M}$ de MK-801 e 2,5 $\mathrm{MM}$ de Quisqualato.

A ligação não específica foi obtida através da incubação das secções com ligante radioativo juntamente com MK-801, ácido kaínico e quisqualato não marcados.

A lavagem das secções foi feita com 3 mergulhos em água destilada. Em seguida, as secções foram secas sob ventilação fria e expostas a filme radioautográfico sensível ao trício (Hyperfilm ${ }^{3} \mathrm{H}$, Amersham Biosciences) em um cassete para exposição de filmes radioautográficos por 8 semanas.

Para os receptores de glutamato, não há experimentos anteriores do laboratório que determinaram o $\mathrm{K}_{\mathrm{D}}$, importante para a análise da ligação. Neste caso, a padronização da metodologia e determinação do $K_{D}$ foram feitos anteriormente ao experimento para análise da ligação dos receptores ionotrópicos de glutamato após tratamento crônico com nicotina.

Para a determinação do $K_{D}$ dos 3 subtipos de receptores ionotrópicos de glutamato, utilizou-se a técnica de wipe off para realização de experimentos de saturação em secções de NTS de 4 ratos SHR não experimentais, os quais tiveram o núcleo seccionado da mesma forma já descrita.

As secções foram então expostas a concentrações crescentes do ligante radioativo juntamente com os ligantes frios específicos a fim de se obter a ligação em um só subtipo de receptor. As concentrações foram de $17 \mathrm{nM}$ a $19 \mu \mathrm{M}$. Após a incubação e lavagem (exatamente conforme descrito anteriormente) as secções foram transferidas para tubos especiais contendo 
$5 \mathrm{~mL}$ de líquido de cintilação biodegradável (Ecolite) para contagem em aparelho de cintilação (Tri-carb 2100TR Liquid Scintilation Analyzer, Packard).

\section{Quantificação dos filmes radioautográficos}

Após o período de exposição, os cassetes foram abertos em câmara escura e os filmes do tipo Biomax-MR revelados como os radioautogramas da hibridização in situ. Os filmes Hyperfilm ${ }^{3} \mathrm{H}$ foram submetidos ao revelador D19 (Kodak) durante 3 minutos, brevemente lavados em água destilada seguido de fixador GBX (Kodak) durante 15 minutos. A análise dos filmes deu-se através do mesmo sistema de análise de imagens já descrito para a hibridização in situ. Neste caso, a graduação dos tons cinza dos filmes radioautográficos marcados pela radioatividade liberada das secções, obtida através de medidas bilaterais dos núcleos encefálicos de interesse, foi comparada com a de uma escala padrão de emissão de radioatividade (Amersham Biosciences).

\subsection{Experimentos com cultura de células}

\subsubsection{Cultura Primária de Neurônios e Células Gliais}

Utilizaram-se ratos (Rattus norvegicus albinus) neonatos das linhagens SHR, com predisposição genética à hipertensão, e Wistar Kyoto (WKY), normotensos, provenientes do biotério da Faculdade de Medicina da Universidade da Flórida. Para a cultura de neurônios foram utilizados ratos neonatos com menos de 1 dia de idade, preferindo-se aqueles que acabaram de nascer. Ratos com até 2 dias de idade foram utilizados para fazer a cultura de células gliais.

Os ratos foram eutanaziados com excesso de anestésico (Nembutal) administrado intraperitonealmente e lavados com álcool 75\%. Em fluxo 
laminar, os encéfalos foram removidos rapidamente e colocados em solução, a $37^{\circ} \mathrm{C}$, contendo $\mathrm{NaCl}(140 \mathrm{mM}), \mathrm{KCl}(54 \mathrm{mM}), \mathrm{Na}_{2} \mathrm{PO}_{4}(0,17 \mathrm{mM}), \mathrm{KH}_{2} \mathrm{PO}_{4}$ $(0,07 \mathrm{mM})$, glicose $(5,5 \mathrm{mM})$, sacarose $(59 \mathrm{mM})$, penicilina $(100.000 \mathrm{U} / \mathrm{L})$, streptomicina $(0,1 \mathrm{~g} / \mathrm{L})$ e fungicida $(0,25 \mathrm{mg} / \mathrm{L})$. Os encéfalos foram então dissecados e as áreas de interesse (tronco encefálico e hipotálamo, FIGURA 9) separadas para uma nova placa de petri contendo a mesma solução previamente descrita. Ao final da dissecação, removeu-se o excesso de solução das placas de petri contendo as regiões de interesse e estas foram cortadas com auxílio de uma tesoura cirúrgica a fim de se obter pedaços menores que $1 \mathrm{~mm}^{3}$. As regiões trituradas foram então transferidas para tubos de polipropileno. Em seguida, adicionou-se $1 \mathrm{~mL}$ de tripsina (solução a $0,25 \%$ ) por encéfalo em cada tubo e incubou-se à $37^{\circ} \mathrm{C}$ durante 5 minutos. Depois, adicionaram-se $160 \mathrm{mg}$ de DNAse I à solução incubando-se por mais 5 minutos em banho maria à $37^{\circ} \mathrm{C}$. A esta solução foram adicionados $20 \mathrm{~mL}$ de meio de cultura constituído de DMEM contendo glicose, L-glutamina e piruvato de sódio (Gibco), suplementado com $10 \%$ de soro equino, streptomicina $(0,1 \mathrm{~g} / \mathrm{L})$ e penicilina $(100.000 \mathrm{U} / \mathrm{L})$. Centrifugou-se por 5 minutos a $2.200 \mathrm{rpm}$ a $24^{\circ} \mathrm{C}$. Removeu-se o sobrenadante e o precipitado foi ressuspenso em $10 \mathrm{~mL}$ de meio de cultura. As células foram então dissociadas com o auxílio de uma pipeta Pasteur através de gentis e repetidos movimentos de sucção. A solução contendo as células dissociadas foi transferida para um novo tubo sendo filtrada em gaze a fim de reter possíveis pedaços de tecido não dissociado. As células foram contadas com o auxílio de câmara de neubauer e plaqueadas (2000 células $/ \mathrm{mm}^{2}$ ) em placas de petri (Nunclon ${ }^{\mathbf{T M}}, 35 \mathrm{~mm}$ ) previamente tratadas com poli-1-lisina (Sigma, P.M.100.000) durante 4 horas a $37^{\circ} \mathrm{C}$, e mantidas em incubadora a $37^{\circ} \mathrm{C}$ com $90 \%$ de umidade e $5 \% \mathrm{CO}_{2}$.

Para a cultura de neurônios, foi feita co-cultura de tronco encefálico e hipotálamo através da junção destas duas partes dissecadas. Após três dias de incubação das células, o meio de cultura foi substituído por um contendo 
$10 \mu \mathrm{M}$ de citosina arabinose (ARC, Sigma), ficando nesta condição por dois dias, após os quais a ARC foi removida através de substituição do meio de cultura, a partir de então não se trocou mais o meio de cultura. Após 10 dias de cultura, os neurônios foram submetidos à experimentação.

Para a cultura de células gliais, após três dias de incubação, o meio foi substituído por um contendo $10 \%$ de soro fetal bovino, streptomicina $(0,1 \mathrm{~g} / \mathrm{L})$ e penicilina $(100.000 \mathrm{U} / \mathrm{L})$, e renovado a cada três dias até o décimo quarto quando foram utilizadas para experimentos. Neste caso, as culturas de células gliais foram separadas em tronco encefálico, hipotálamo ou co-cultura (tronco e hipotálamo).

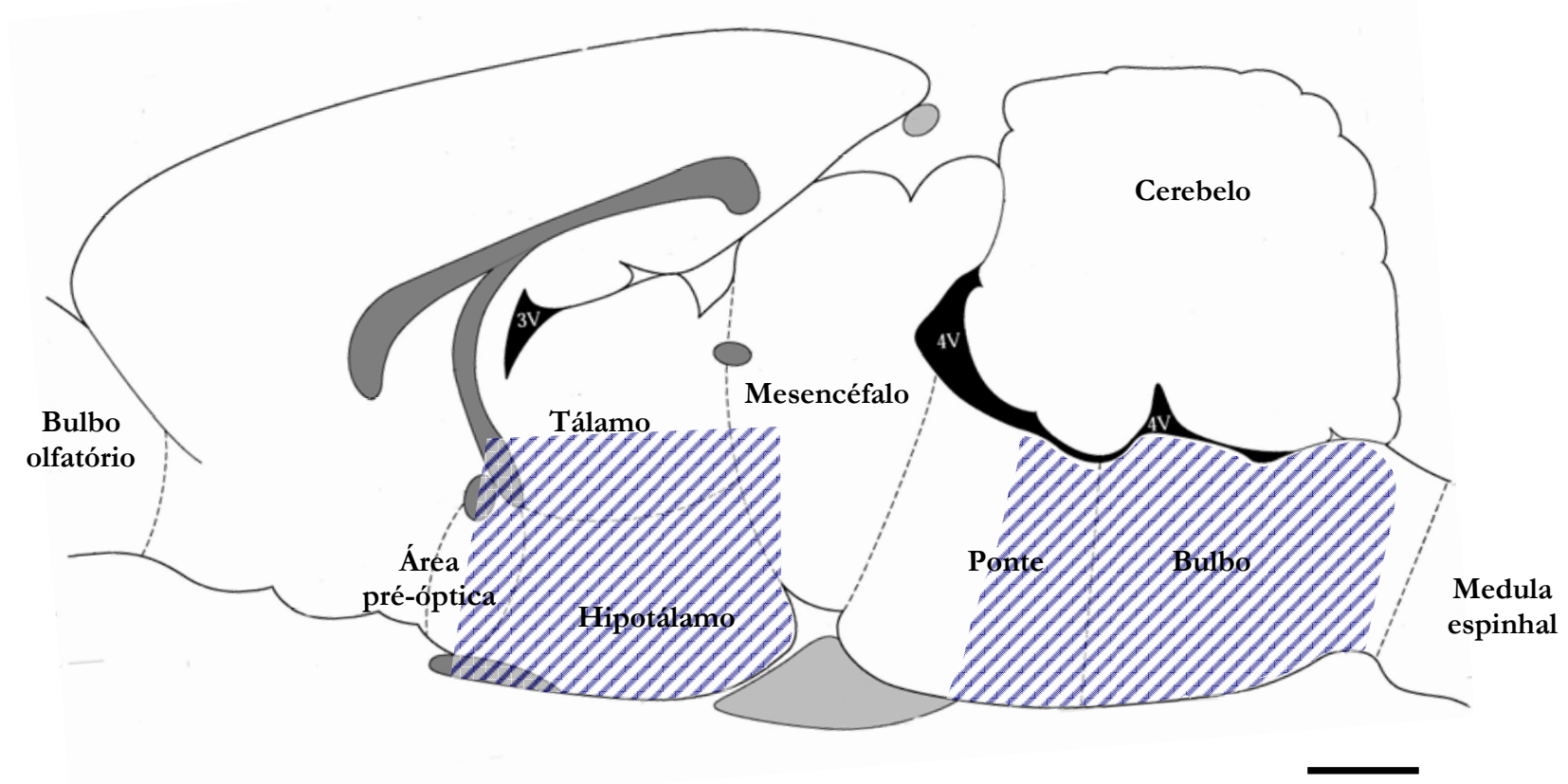

FIGURA 9. Esquema de um encéfalo de rato seccionado longitudinalmente ilustrando as regiões dissecadas (hachuradas) para a cultura de células do hipotálamo e tronco encefálico. Barra de escala $=1 \mathrm{~mm}$. 


\subsubsection{Tratamento com nicotina}

As células foram tratadas com nicotina após 10 (neurônios) ou 14 (células gliais) dias do plaqueamento. Foram feitos experimentos para verificação das curvas dose-resposta e temporal da modulação do sistema angiotensinérgico pela nicotina.

Para o experimento de curva temporal, as células foram incubadas com $10 \mu \mathrm{M}$ de nicotina ( \pm nicotina, Sigma, EUA) durante 4, 12, 24 ou 48 horas. A resposta dose-dependente foi verificada através de incubação das culturas por 24 horas com 1, 10 ou $100 \mu \mathrm{M}$ de nicotina. A droga foi diluída em meio de cultura que foi aplicado sobre as células.

Após o tempo destinado ao tratamento, as células foram lavadas e instantaneamente submetidas à análise de ligação, proteína ou RNA mensageiro dos componentes do sistema angiotensinérgico.

\subsubsection{Imunocitoquímica}

Culturas de células gliais e neuronais foram submetidas à imunocitoquímica com o objetivo de caracterização e a fim de se verificar sua homogeneidade. Para tanto, após 10 ou 14 dias, para neurônios e células gliais, respectivamente, as células foram lavadas por 2 vezes com PBS, fixadas com solução de paraformaldeído gelado a 4\% durante 1 minuto, lavadas novamente por 2 vezes com PBS, fixadas com metanol à $-20^{\circ} \mathrm{C}$ e lavadas por 3 vezes com PBS contendo 0,2\% de Triton X 100 (Sigma).

Para a marcação da astroglia, o anticorpo contra a proteína glial fibrilar ácida (GFAP, Cy3 conjugado, Sigma) foi preparado em concentração de 1:200 diluído em PBS contendo $0,2 \%$ de Triton. As células foram incubadas com o anticorpo durante 12 horas à $4^{\circ} \mathrm{C}$, sendo depois lavadas por 3 vezes com 
PBS/Triton, cobertas com meio de montagem contendo DAPI (Vector) e lamínula de vidro.

Os neurônios foram marcados com anticorpo contra a proteína de núcleo neuronal NeuN (1:100, Chemicon) através de incubação à $4^{\circ} \mathrm{C}$ durante 24 horas, após a qual incubou-se por 2 horas com anticorpo fluorescente antimouse (Alexa Fluor 594, 1:250, Molecular Probe) em temperatura ambiente. Todos os anticorpos foram diluídos em PBS 0,1M contendo 0,2\% de triton, as lavagens foram feitas da mesma forma que para glia e os neurônios cobertos com meio contendo DAPI, como também descrito para as células gliais.

As placas foram analisadas em microscópio Zeiss Axioplan2 acoplado a uma câmera fotográfica digital (Spot) através da qual foram adquiridas as fotomicrografias. As imagens adquiridas de um mesmo campo, utilizando-se filtros diferentes para o vermelho (GFAP ou NeuN) e azul (DAPI), foram sobrepostas através do programa Spot (Spot camera, USA) a fim de se comparar a quantidade de células marcadas com GFAP ou NeuN e os demais tipos celulares marcados somente com DAPI.

\subsubsection{Ligação}

Culturas de células gliais e neurônios foram submetidas à análise de ligação dos receptores $\mathrm{AT}_{1}$ de angiotensina II após tratamento com nicotina. Os receptores $\mathrm{AT}_{2}$ só foram analisados em cultura de neurônios visto que não há detecção de ligação nestes receptores em células da glia.

Após o tempo de tratamento com nicotina, as células foram lavadas rapidamente com PBS à temperatura ambiente por duas vezes. Os poços destinados à marcação total foram incubados com uma mistura contendo BSA 8\% e ${ }^{125}$ I AngII (400.000cpm/mL) em PBS. Para a análise da ligação não específica, à mesma mistura foi adicionado losartan $(10 \mu \mathrm{M}$, para bloqueio dos receptores $\left.\mathrm{AT}_{1}\right)$ ou $\mathrm{PD} 123319\left(10 \mu \mathrm{M}\right.$, para bloquear os receptores $\left.\mathrm{AT}_{2}\right) . \mathrm{A}$ 
solução $(500 \mu \mathrm{L} /$ poço) foi colocada sobre as células que ficaram incubando à temperatura ambiente por 30 minutos, sendo depois lavadas extensivamente (4x) com PBS gelado. As células foram lisadas com $\mathrm{NaOH}(0,1 \mathrm{~N}, 500 \mu \mathrm{L})$ por 1 hora e a solução transferida para microtubos, cada poço foi lavado com $500 \mu \mathrm{L}$ de água e coletado no mesmo tubo contendo o $\mathrm{NaOH}$ e as células lisadas. Desta solução, $500 \mu \mathrm{L}$ foram transferidos para tubos contendo líquido de cintilação que foram submetidos à leitura em contador de cintilação (Packard).

A marcação específica dos receptores foi calculada subtraindo-se o valor correspondente à ligação não específica (na presença de antagonista não radioativo) da ligação total.

Os resultados foram normalizados pela quantidade de proteína em cada poço da placa. Para isso uma alíquota de $10 \mu \mathrm{L}$ de cada amostra experimental foi submetida à análise protéica utilizando-se o método de Bradford. Em cada tubo especial para espectrofotômetro (Cuvette, Fisher, EUA) foram adicionados, proteína $(10 \mu \mathrm{L}), \mathrm{HCl}(0,1 \mathrm{~N}, 10 \mu \mathrm{L})$ para neutralizar o $\mathrm{NaOH}$ em que as células foram lisadas, água $(780 \mu \mathrm{L})$ e $200 \mu \mathrm{L}$ de solução concentrada de Bradford (Protein Assay, Bio-Rad). A curva de calibração foi feita utilizando-se albumina $(1 \mathrm{mg} / \mathrm{mL})$ em concentrações de 0 a $5 \mu \mathrm{g} / \mu \mathrm{L}$.

\subsubsection{Extração e Quantificação de RNA}

O ambiente de trabalho foi limpo utilizando-se solução descontaminante de RNAse (RNAse ZAP, Ambion), também foram utilizados tubos, ponteiras e soluções livres de RNAses. Para a extração de RNA, utilizaram-se kit e protocolo provenientes da empresa Ambion (RNAqueous4PCR, Ambion, USA). Para efeitos de concentração de RNA, as células de 2 
ou 3 poços foram colocadas em um só tubo já que a quantidade de células por poço gera pequena quantidade dos RNAs de interesse.

As amostras foram lisadas com $150 \mu \mathrm{L}$ de solução de lise por poço contendo as células que foram rompidas pipetando-se vigorosamente para acelerar a lise. O lisado foi transferido para um microtubo e agitado em vortex $^{\text {TM }}$ para completar a ruptura das células. Adicionou-se igual volume de etanol $64 \%$ às amostras e agitou-se novamente. As amostras foram então aplicadas sobre filtro especial que retém o RNA colocado em microtubo de polipropileno e centrifugadas a $10000 \mathrm{rpm}$ por um minuto. O filtrado foi descartado e o RNA foi lavado adicionando-se $700 \mu \mathrm{L}$ de solução de lavagem $\mathrm{n}^{\mathrm{o}} 1$, centrifugou-se por mais 1 minuto a 10000rpm. Lavou-se por mais duas vezes o RNA agora com $500 \mu \mathrm{L}$ das soluções de lavagem nº e 3 centrifugando-se em cada lavagem por 1 minuto a 10000rpm, descartando-se sempre os filtrados. O filtro contendo o RNA foi transferido para um novo tubo livre de RNAse onde, através da aplicação da solução de eluição por 2 vezes consecutivas $(20 \mu \mathrm{L}+10 \mu \mathrm{L})$ e centrifugando, o RNA foi recuperado. Para livrar o RNA de possíveis contaminações com DNA genômico, o que interfere na análise por RT-PCR em tempo real, adicionaram-se $3 \mu \mathrm{L}$ do tampão de DNAseI e $1 \mu \mathrm{L}$ de DNAse I, incubando-se a $37^{\circ} \mathrm{C}$ por 30 minutos. A DNAse foi inativada através da adição de reagente inativador de DNAse e misturado gentilmente. Os tubos foram centrifugados para precipitar a mistura de DNAse I, e o RNA foi transferido para um novo tubo que foi armazenado em freezer a $-80^{\circ} \mathrm{C}$ até sua utilização.

Para acessar a quantidade e qualidade do RNA extraído, primeiramente uma amostra diluída a 1:50 em tampão TE foi submetida a espectrofotômetro para ter a absorbância à UV determinada e sua concentração. Após a determinação da concentração de RNA por tubo, uma outra amostra de $15 \mu \mathrm{L}$ contendo $1,5 \mu \mathrm{g}$ de RNA total foi colocada em gel de agarose $1 \%$ contendo 
brometo de etídio $(0,1 \mu \mathrm{g} / \mathrm{mL})$ e submetidas à corrida nas seguintes condições: pólo positivo para o negativo, $80 \mathrm{~V}$, durante 30 minutos com tampão de corrida constituído de TBE.

\subsubsection{PCR em Tempo Real}

Após a certificação de que o RNA extraído estava intacto, procedeu-se à transformação do mesmo em cDNA dupla fita, através de transcrição reversa, a fim de amplificar e tornar a molécula mais estável. Para tanto, a $1 \mu \mathrm{g}$ de RNA total foram adicionados reagentes para a transcrição reversa assim como a enzima transcriptase reversa seguindo o protocolo do fabricante (TaqMan Applied Biosystems, EUA). Resumidamente, adicionaram-se tampão TaqMan (1X), $\mathrm{MgCl}_{2}(5,5 \mathrm{M})$, nucleotídeos $(500 \mu \mathrm{M})$, hexâmeros randômicos $(2,5 \mu \mathrm{M})$, inibidor de RNAse $(0,4 \mathrm{U} / \mu \mathrm{L})$ e a enzima transcriptase reversa $(1,25 \mathrm{U} / \mu \mathrm{L}$, MultiScribe Reverse Transcriptase), assim como a quantidade de RNA em cada amostra em um tubo de polipropileno próprio para PCR atingindo o volume final de $50 \mu \mathrm{L}$. Além dos tubos experimentais, outros 2 tubos controles foram inseridos no ensaio: um sem a enzima transcriptase reversa e outro sem o RNA. Os tubos foram colocados em termociclador com o seguinte protocolo: 10 minutos de incubação a $25^{\circ} \mathrm{C}$ seguidos de 30 minutos de transcrição a $48^{\circ} \mathrm{C}$ e 5 minutos a $95^{\circ} \mathrm{C}$ para inativação da enzima. Ao final do procedimento o cDNA foi estocado em freezer a $-80^{\circ} \mathrm{C}$ até sua utilização para quantificação da expressão gênica através de RT-PCR em tempo real.

As probes e primers utilizados continham FAM ${ }^{\mathrm{TM}}$ como repórter fluorescente e são comercialmente disponíveis através da empresa Applied Biosystems. Foram avaliados os RNAm do angiotensinogênio (AOGEN), enzima conversora de angiotensina (ECA) e dos receptores $\mathrm{AT}_{1}$ e $\mathrm{AT}_{2}$. Como controle de amplificação, utilizaram-se primers e probe para RNA ribossômico (18S) que continham o repórter VIC ${ }^{\mathbf{T M}}$ também comercialmente disponíveis (Applied Biosystems, EUA). A tabela 1 exemplifica o protocolo utilizado. 
As soluções foram colocadas em placa de 96 poços com qualidade óptica (ABI Prism, Applied Biosystems, EUA) que foi lacrada com adesivo também com qualidade óptica (ABI Prism, Applied Biosystems, EUA) e submetida à amplificação e detecção através de PCR em tempo real (modelo 7700, ABI Prism, Applied Biosystems, EUA) por 50 ciclos.

Os dados referentes aos RNAm de estudo foram normalizados através de subtração dos valores referentes ao $18 \mathrm{~S}$ e comparados entre si por normalização logarítmica $\left(2^{-\Delta \Delta_{\mathrm{CT}}}\right)$.

TABELA 1. Protocolo utilizado para o preparo das amostras que foram submetidas à análise por PCR em tempo real.

\begin{tabular}{lc}
\hline $\mathbf{1 8 S}$ & Volume por reação $(\mathbf{2 5} \mu \mathrm{L})$ \\
\hline 2x Master Mix & $12,5 \mu \mathrm{L}$ \\
Probe & $0,156 \mu \mathrm{L}$ \\
Primers & $0,25 \mu \mathrm{L}$ \\
cDNA (diluído 1:100) & $5 \mu \mathrm{L}$ \\
Água DEPC & $6,84 \mu \mathrm{L}$ \\
\hline $\mathbf{A T}_{1} \mathbf{R} / \mathbf{A T}_{2} \mathbf{R} / \mathbf{E C A} / \mathbf{A O G E N}$ & \\
\hline 2x Master Mix & $12,5 \mu \mathrm{L}$ \\
Probe/primers & $1,25 \mu \mathrm{L}$ \\
cDNA & $5 \mu \mathrm{L}$ \\
Água DEPC & $6,25 \mu \mathrm{L}$ \\
\hline
\end{tabular}

\subsubsection{Extração de proteina e Western Blot}

As células foram lavadas com PBS a temperatura ambiente, descoladas das placas com auxílio de um bastão de borracha para não haver muita lise celular e reservadas em microtubos de centrífuga. As células de três placas 
foram combinadas num mesmo tubo a fim de concentrar a proteína total extraída. A este tubo foram adicionados $100 \mu \mathrm{L}$ de tampão de lise constituído de NP40 (1\%), deoxicolato de sódio (0,5\%), SDS (1\%), EDTA (1mM), EGTA $(1 \mathrm{mM})$ e coquetel inibidor de proteases (Sigma, 1\%) em PBS. As células foram lisadas através de pipetagem vigorosa, agitação e sonicagem. Após a extração protéica, os tubos foram centrifugados a $10000 \mathrm{rpm}$ durante 30 minutos a $4^{\circ} \mathrm{C}$, e procedeu-se a quantificação da proteína através de espectrofotômetro e solução de Bradford assim como já mencionado para a normalização dos dados dos experimentos de ligação.

As amostras foram diluídas em tampão de lise a fim de se obter soluções de $15 \mu \mathrm{g}$ de proteína total em $13 \mu \mathrm{L}$ de solução que foram desnaturadas à $100^{\circ} \mathrm{C}$ durante 3 minutos e aplicados às canaletas do gel de poliacrilamida a 12\%. Em um dos pocinhos foram aplicados $8 \mu \mathrm{L}$ de marcador de peso molecular (Kaleidoscope, pré-corado, Bio-Rad, EUA). O tampão de corrida foi preparado com trisma $(25 \mathrm{mM})$, glicina $(0,2 \mathrm{M})$ e SDS $(0,1 \%)$, as proteínas foram separadas através de aplicação de 125 volts durante 2 horas.

Após a corrida, as proteínas foram transferidas para membrana de nitrocelulose (Bio-Rad) utilizando tampão gelado contendo trisma (25mM), glicina $(0,2 \mathrm{M})$ e metanol $(10 \%)$ durante 1 hora a $100 \mathrm{~V}$.

A membrana foi então incubada com solução de bloqueio dos sítios não ocupados. O protocolo de bloqueio e incubação dos anticorpos variou de acordo com o seguinte:

- $\mathbf{A} \mathbf{T}_{2} \mathbf{R}$ : bloqueio com leite a 5\% em TBS-T (150mM NaCl, $10 \mathrm{mM}$ Tris, 0,05\% tween 20) durante $1 \mathrm{~h}$ à temperatura ambiente sob agitação. Incubação com anticorpo primário diluído a 1:200 (anti-AT 2 R, Santa Cruz, EUA) em leite a 3\% em TBS-T durante 2 horas à temperatura ambiente seguida de duas lavagens com TBS-T por 10 minutos cada. O anticorpo secundário (anti-cabra, 
HRP conjugado, Santa Cruz, EUA) foi diluído a 1:2000 em 3\% leite em TBS-T e aplicado à membrana durante 45 minutos à temperatura ambiente.

- AT 1 R: bloqueio com leite desnatado a 5\% em TBS-T durante 1 hora à temperatura ambiente sob agitação. Incubação com anticorpo primário diluído a 1:1000 (anti-AT ${ }_{1}$ R, Santa Cruz, EUA) em leite a 3\% em TBS-T durante a noite a $4^{\circ} \mathrm{C}$ sob agitação seguida de duas lavagens com TBS-T por 10 minutos cada. O anticorpo secundário (anti-coelho, HRP conjugado, Santa Cruz, EUA) foi diluído a 1:10000 em 3\% leite em TBS-T e aplicado à membrana durante 1 hora a temperatura ambiente.

-ECA2: bloqueio com leite a 5\% e 1\% de BSA em TBS-T durante 24 horas à $4^{\circ} \mathrm{C}$ sob agitação. Incubação com anticorpo primário diluído a 1:200 (anti-ace2, Santa Cruz, EUA) em solução de bloqueio durante 1 hora à temperatura ambiente seguida de quatro lavagens com TBS-T por 10 minutos cada. O anticorpo secundário (anti-coelho, HRP conjugado, Santa Cruz, EUA) foi diluído a 1:10000 em 3\% leite em TBS-T e aplicado à membrana durante 45 minutos à temperatura ambiente.

- $\alpha$-tubulina: bloqueio com leite a 3\% em TBS-T durante 1 hora à temperatura ambiente. Incubação com anticorpo primário diluído a 1:30000 (anti- $\alpha$-tubulin, Sigma, EUA) em solução de BSA a 1\% em TBS-T durante 1 hora em temperatura ambiente seguida de duas lavagens com TBS-T por 10 minutos cada. O anticorpo secundário (anti-camundongo, HRP conjugado, Amersham, EUA) foi diluído a 1:6000 em 1\% BSA em TBS-T e aplicado à membrana durante 45 minutos à temperatura ambiente.

Após a incubação com os anticorpos secundários, as membranas foram lavadas por duas vezes com TBS-T e uma vez com TBS durante 10 minutos cada. A reação aconteceu através de incubação com reagente quimioluminescente (Western Lightning Chemiluminescence Reagent Plus, ECL kit, Perkinelmer, EUA) durante exatamente 1 minuto. As membranas 
foram expostas a filme sensível (Kodak, Japão) durante 30 segundos a 2 minutos e revelados conforme instruções do fabricante.

Os filmes foram quantificados através de densitometria óptica usando o digitalizador de imagens Bio-Rad GS-710 (Bio-Rad, EUA) e o programa Quantity One (Bio-Rad, EUA).

\section{ANÁlise Estatística}

Os dados obtidos foram analisados através do teste $\mathrm{t}$ de Student ou análise de variância (ANOVA) de uma ou duas vias, dependendo do caso, o que será relatado no momento da apresentação de cada resultado. A análise estatística foi feita utilizando-se o programa GraphPad Prism, versão 3.00 de 25 de março de 1999, para Windows (GraphPad Software, San Diego California USA). Foram aceitas como variações significativas aquelas em que a diferença entre os grupos resultou em um $p$ menor ou igual a 0,05 . 
RESULTADOS 


\section{RESUltados}

\subsection{Quantificação da nicotina e cotinina plasmáticas}

A análise cromatográfica do plasma através de HPLC demonstrou que o tratamento com nicotina foi eficiente. A nicotina e a cotinina foram encontradas somente nos ratos que tiveram as pastilhas de nicotina implantadas, não houve qualquer detecção de nicotina ou seu metabólito nos ratos implantados com pastilhas placebo (Figura 10). A concentração média de nicotina e cotinina encontrada no plasma dos animais tratados foi de $30 \pm 7 \mathrm{ng} / \mathrm{mL}$. Esta quantidade permaneceu constante durante todo o tratamento (8 semanas). No entanto, a substituição das pastilhas, na terceira semana, provocou um aumento muito grande na concentração de nicotina e cotinina, média de 700 e $300 \mathrm{ng} / \mathrm{mL}$, respectivamente, no plasma dos ratos tratados, tendo retornado aos níveis de $30 \mathrm{ng} / \mathrm{mL}$ na semana subseqüente.

O método de quantificação foi validado através da construção de curvas de calibração para cada substância analisada. Como se pode observar na figura 11, a validação foi adequadamente obtida, pois se obtiveram valores entre 0,9 e 1,0 para a correlação linear.

Isto indica que a absorbância das substâncias analisadas foi direta e linearmente proporcional às concentrações utilizadas para a calibração do sistema de cromatografia. Esta calibração serviu também para a confirmação de que as concentrações de nicotina e cotinina plasmáticas foram precisamente quantificadas. 

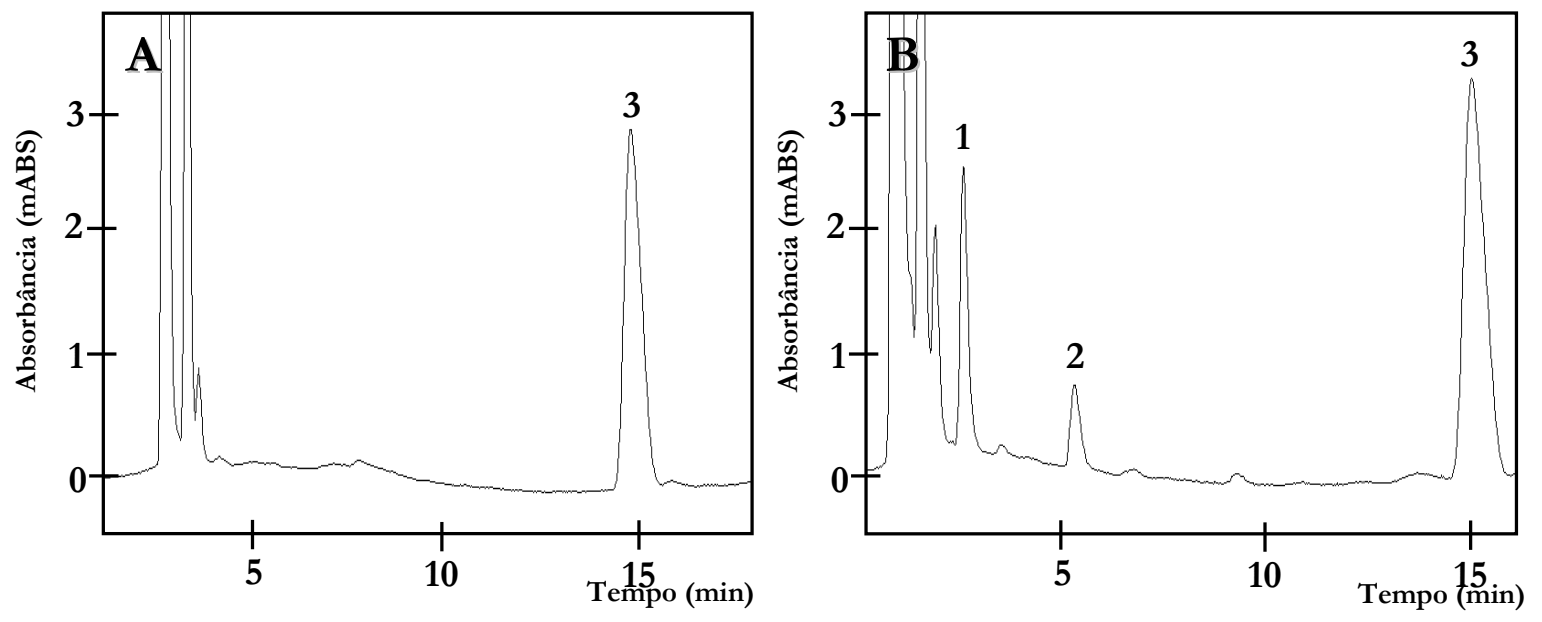

FIGURA 10. Cromatogramas representativos ilustrando o perfil das curvas de absorbância da nicotina (1), cotinina (2) e acetanilida (3) em rato que recebeu pastilha de placebo (A) ou nicotina (B). 

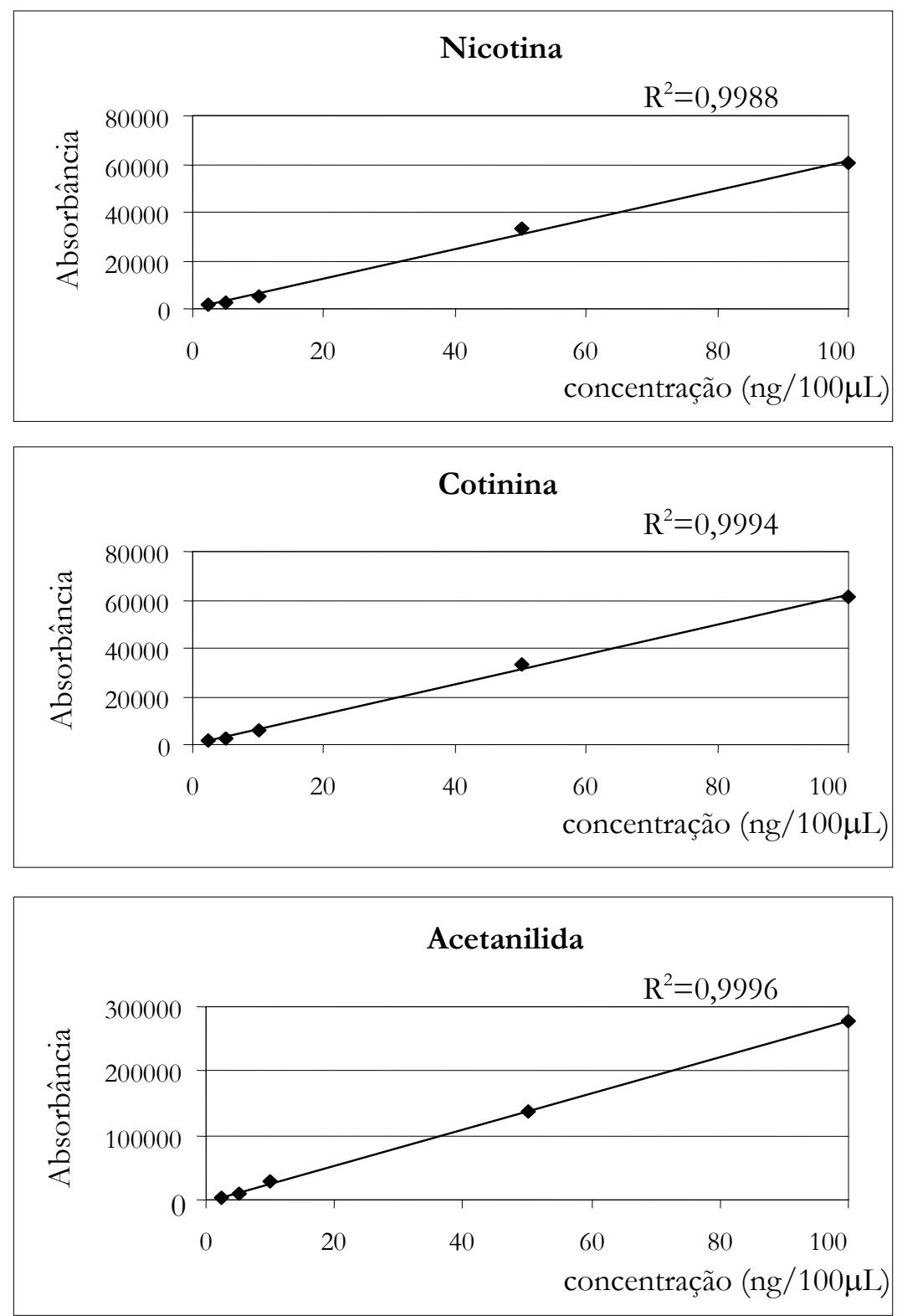

FIGURA 11. Curvas de calibração da nicotina, cotinina e acetanilida demonstrando a validação adequada do método de quantificação da nicotina e seu metabólito no plasma, assim como o uso da acetanilida como um bom padrão interno, pois o coeficiente de correlação obtido encontra-se entre 0,9 e 1,0. Cada um dos 5 pontos foi quantificado em triplicada, tendo sido utilizada a média aritmética para a construção das curvas. 


\subsection{Peso}

O peso dos animais não variou significativamente entre os grupos que tiveram pastilhas de nicotina ou placebo implantadas (Tabela 2, Figura 12).

TABELA 2. Variação do peso, em gramas, dos ratos espontaneamente hipertensos (SHR) e normotensos Wistar Kyoto (WKY) tratados com nicotina ou placebo ao longo de 8 semanas.

\begin{tabular}{ccccc}
\hline \multicolumn{5}{c}{ Peso (g) } \\
\hline Semana & Placebo & Nicotina & Placebo & Nicotina \\
0 & $96,3 \pm 5,2$ & $99,3 \pm 4,3$ & $82,5 \pm 7,0$ & $89,4 \pm 5,3$ \\
1 & $137,3 \pm 5,6$ & $138,8 \pm 5,0$ & $116,7 \pm 6,4$ & $116,5 \pm 6,1$ \\
2 & $171,2 \pm 4,9$ & $168,8 \pm 4,5$ & $150,4 \pm 6,8$ & $159,6 \pm 5,8$ \\
3 & $206,4 \pm 4,3$ & $207,6 \pm 4,9$ & $183,9 \pm 7,4$ & $197,6 \pm 5,9$ \\
4 & $217,6 \pm 2,9$ & $224,4 \pm 4,3$ & $216,0 \pm 7,4$ & $226,5 \pm 5,6$ \\
5 & $251,7 \pm 4,5$ & $248,2 \pm 5,3$ & $245,0 \pm 7,2$ & $255,2 \pm 4,8$ \\
6 & $268,2 \pm 4,8$ & $265,9 \pm 6,3$ & $267,7 \pm 6,6$ & $275,1 \pm 9,4$ \\
7 & $278,8 \pm 5,2$ & $276,1 \pm 7,1$ & $291,1 \pm 6,5$ & $302,0 \pm 7,1$ \\
8 & $290,3 \pm 5,6$ & $282,9 \pm 9,1$ & $301,0 \pm 6,2$ & $317,0 \pm 4,9$ \\
\hline
\end{tabular}

Os valores são apresentados como média aritmética $\pm E P M$ Empregou-se o teste $t$ de Student para a análise estatistica entre os pares durante cada semana de tratamento. $n=12$. 
SHR

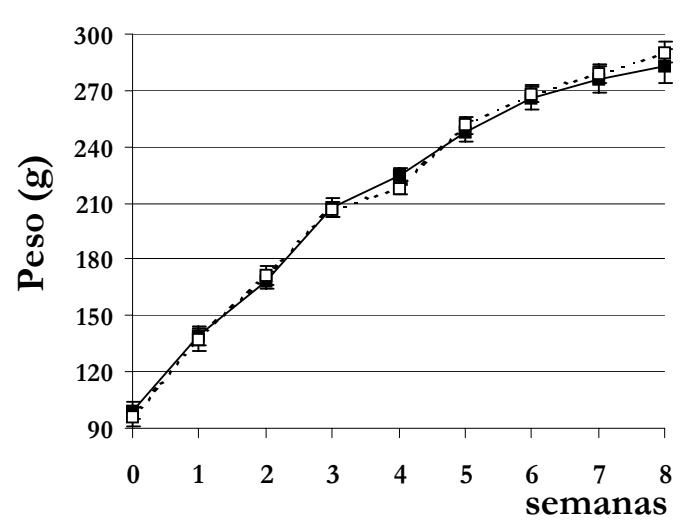

WKY

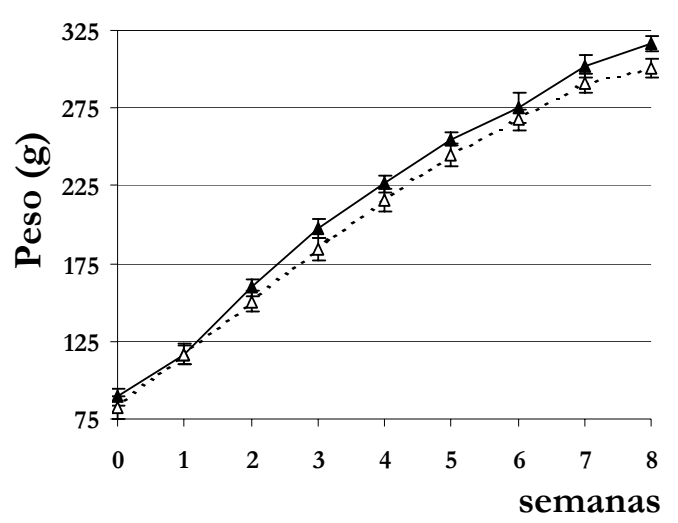

FIGURA 12. Variação do peso, em gramas, dos ratos espontaneamente hipertensos (SHR) e normotensos Wistar Kyoto (WKY) tratados com nicotina (linha contínua) ou placebo (linha tracejada) ao longo de 8 semanas. Os valores são apresentados como média aritmética EPPM Empregou-se o teste $t$ de Student para a análise estatística entre os pares durante cada semana de tratamento.

\subsection{Parâmetros Cardiovasculares}

\subsubsection{Pressão Arterial Sistólica}

A nicotina intensificou e antecipou o aparecimento da hipertensão sistólica nos ratos com predisposição genética para a hipertensão (SHR). O aumento da pressão sistólica iniciou-se logo após 1 semana da implantação das pastilhas, quando estes animais tinham 5 semanas de vida. No entanto, os ratos normotensos tratados com nicotina só apresentaram elevação significativa da pressão arterial sistólica quando a concentração da droga foi exacerbada, na semana subseqüente à substituição das pastilhas (Tabela 3, Figura 13). 
TABELA 3. Variação da pressão arterial sistólica, em milímetros de mercúrio, dos ratos espontaneamente hipertensos (SHR) e normotensos Wistar Kyoto (WKY) tratados com nicotina ou placebo ao longo de 8 semanas.

\begin{tabular}{ccccc}
\hline \multicolumn{4}{c}{$\begin{array}{c}\text { Pressão Arterial Sistólica (mmHg) } \\
\text { SHR }\end{array}$} & \multicolumn{2}{c}{ WKY } \\
\hline Semana & Placebo & Nicotina & Placebo & Nicotina \\
0 & $136,4 \pm 4,9$ & $144,1 \pm 3,3$ & $135,2 \pm 4,2$ & $135,8 \pm 3,9$ \\
1 & $143,2 \pm 4,4$ & $162,3 \pm 4,5^{* *}$ & $144,0 \pm 6,1$ & $154,9 \pm 6,7$ \\
2 & $142,1 \pm 5,0$ & $157,1 \pm 4,5^{*}$ & $146,8 \pm 5,5$ & $154,8 \pm 4,1$ \\
3 & $156,4 \pm 5,8$ & $172,2 \pm 4,5^{*}$ & $141,2 \pm 2,2$ & $148,5 \pm 5,3$ \\
4 & $167,0 \pm 3,9$ & $180,3 \pm 4,2^{*}$ & $153,9 \pm 5,2$ & $171,4 \pm 3,5^{*}$ \\
5 & $163,7 \pm 4,4$ & $177,8 \pm 3,3^{*}$ & $164,4 \pm 6,7$ & $146,5 \pm 7,3$ \\
6 & $174,3 \pm 5,5$ & $189,4 \pm 3,8^{*}$ & $161,4 \pm 6,4$ & $157,8 \pm 3,8$ \\
7 & $178,6 \pm 1,8$ & $186,8 \pm 2,6^{*}$ & $154,5 \pm 3,5$ & $149,9 \pm 2,5$ \\
8 & $174,8 \pm 3,9$ & $189,4 \pm 3,8^{*}$ & $146,2 \pm 1,5$ & $145,3 \pm 2,9$ \\
\hline
\end{tabular}

Os valores são apresentados como média aritmética $\pm E P M$ ${ }^{*} p<0,05 ;{ }^{* *} p=0,005$ comparados com seus respectivos controles em cada semana de acordo com o teste $t$ de Student. $n=12$.
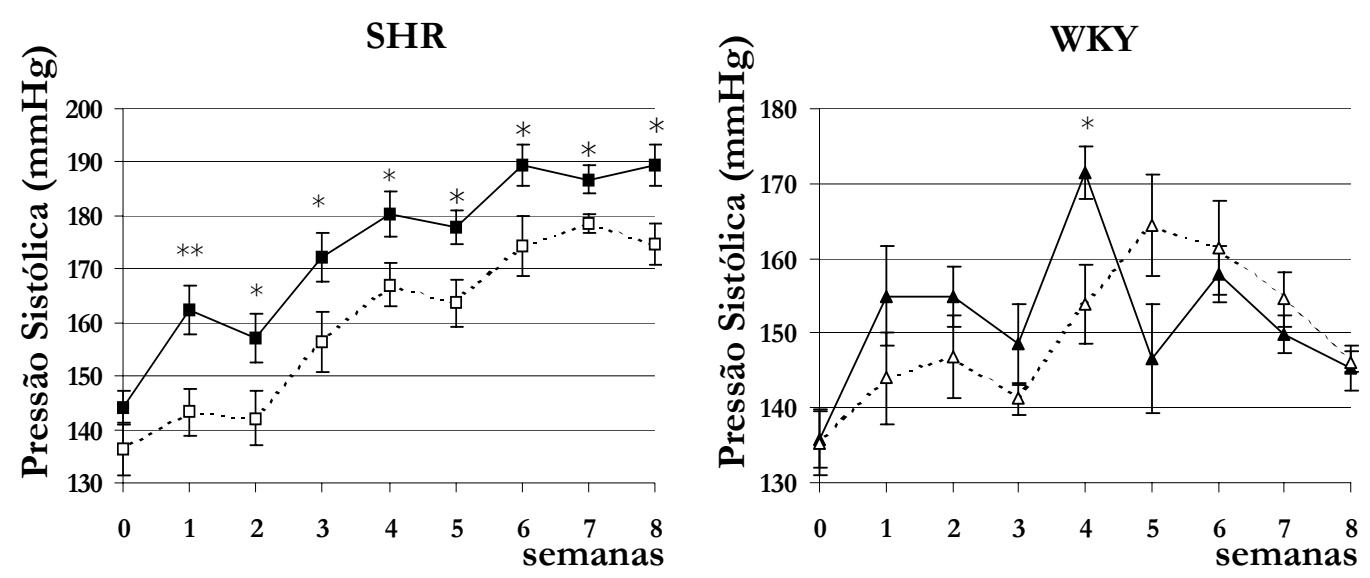

FIGURA 13. Variação da pressão arterial sistólica, em milímetros de mercúrio, dos ratos espontaneamente hipertensos (SHR) e normotensos Wistar Kyoto (WKY) tratados com nicotina (linha contínua) ou placebo (linha tracejada) ao longo de 8 semanas. Os valores são apresentados como média aritmética \pm EPM ${ }^{*} p<0,05 ;{ }^{* *} p=0,005$ comparados com seus respectivos controles em cada semana de acordo com o teste $t$ de Student. $n=12$. 


\subsubsection{Pressão Arterial Média}

Os ratos SHR tratados com nicotina apresentaram aumento significativo da pressão arterial média, assim como antecipação da hipertensão gerada. $\mathrm{Na} 5^{\mathrm{a}}$ semana de vida os ratos SHR tratados com nicotina já se mostraram hipertensos, sendo que a pressão arterial média destes animais ultrapassou os 130mmHg. Nos ratos WKY, a pressão arterial média, a exemplo da sistólica, aumentou significativamente com o tratamento de nicotina somente com concentrações muito altas da droga (Tabela 4, Figura 14).

TABELA 4. Variação da pressão arterial média, em milímetros de mercúrio, dos ratos espontaneamente hipertensos (SHR) e normotensos Wistar Kyoto (WKY) tratados com nicotina ou placebo ao longo de 8 semanas.

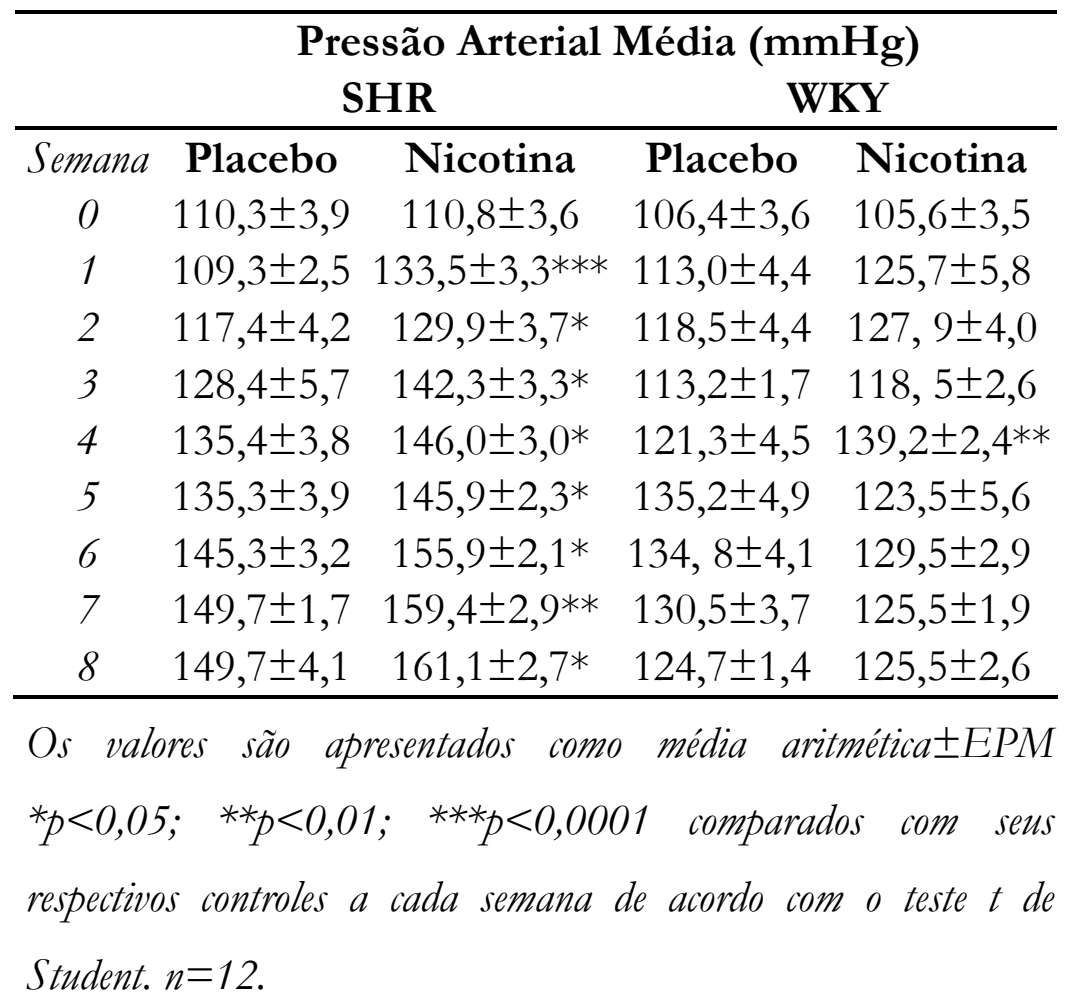



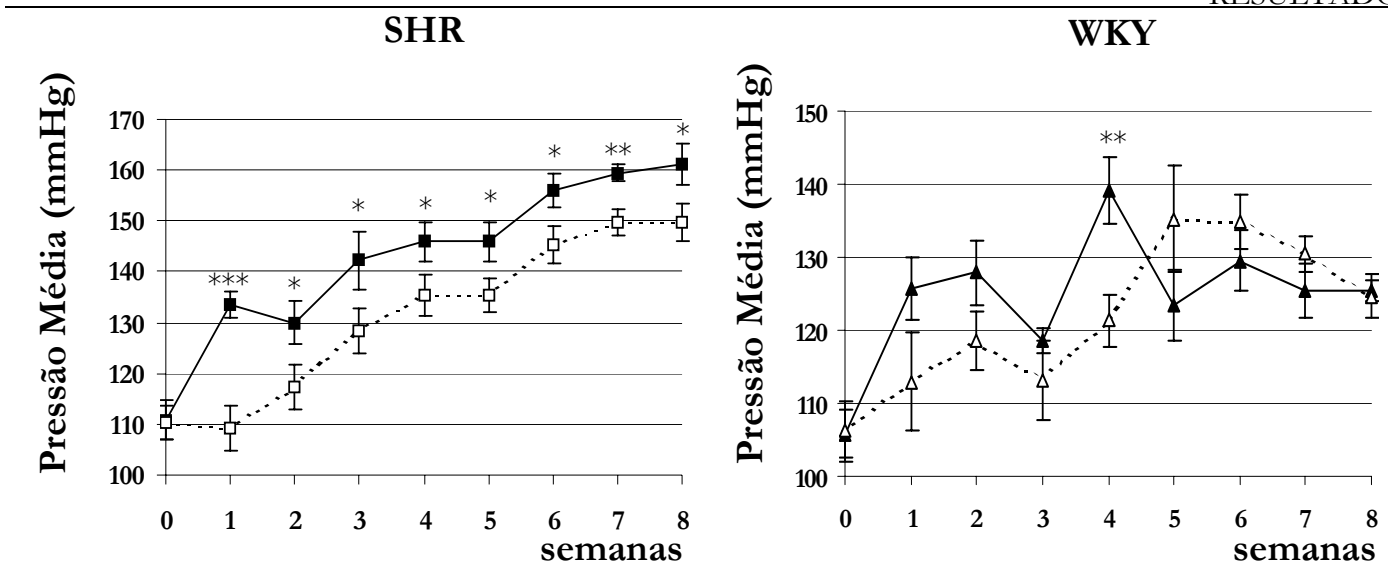

FIGURA 14. Variação da pressão arterial média, em milímetros de mercúrio, dos ratos espontaneamente hipertensos (SHR) e normotensos Wistar Kyoto (WKY) tratados com nicotina (linha contínua) ou placebo (linha tracejada) ao longo de 8 semanas. Os valores são apresentados como média aritmética 士EPM ${ }^{*} p<0,05 ; *^{*} p<0,01 ; *^{* *} p<0,001$ comparados com seus respectivos controles a cada semana de acordo com o teste $t$ de Student. $n=12$.

\subsubsection{Freqüência Cardíaca}

Nos animais com predisposição genética à hipertensão (SHR), o tratamento com nicotina elevou significativamente a freqüência cardíaca se comparados com os que receberam pastilha de placebo. No entanto, os ratos normotensos (WKY) não apresentaram qualquer alteração na freqüência cardíaca durante o tratamento com nicotina (Tabela 5, Figura 15). 
TABELA 5. Variação da freqüência cardíaca, em batimentos por minuto, dos ratos espontaneamente hipertensos (SHR) e normotensos Wistar Kyoto (WKY) tratados com nicotina ou placebo ao longo de 8 semanas.

\begin{tabular}{ccccc}
\hline & \multicolumn{3}{c}{ Freqüência Cardíaca (bpm) } \\
\multicolumn{2}{c}{ SHR } & \multicolumn{2}{c}{ WKY } \\
\hline Semana & Placebo & Nicotina & Placebo & Nicotina \\
0 & $440,4 \pm 9,2$ & $443,7 \pm 8,7$ & $423,2 \pm 11,0$ & $405,3 \pm 10,8$ \\
1 & $423,3 \pm 9,1$ & $449,0 \pm 8,5^{*}$ & $445,2 \pm 6,7$ & $424,9 \pm 8,8$ \\
2 & $425,8 \pm 8,1$ & $456,9 \pm 10,7^{*}$ & $414,4 \pm 10,6$ & $394,1 \pm 8,5$ \\
3 & $382,1 \pm 5,5$ & $411,4 \pm 6,3^{* *}$ & $431,6 \pm 11,4$ & $396,8 \pm 13,1$ \\
4 & $375,9 \pm 7,1$ & $404,1 \pm 8,4^{*}$ & $394,3 \pm 8,6$ & $375,5 \pm 3,9$ \\
5 & $399,0 \pm 8,6$ & $426,3 \pm 8,8^{*}$ & $389,2 \pm 5,9$ & $382,3 \pm 8,5$ \\
6 & $402,3 \pm 6,9$ & $429,8 \pm 7,6^{*}$ & $398,9 \pm 7,9$ & $386,0 \pm 7,3$ \\
7 & $383,1 \pm 8,3$ & $447,4 \pm 14,8^{* * *}$ & $400,3 \pm 8,8$ & $405,5 \pm 7,6$ \\
8 & $401,9 \pm 10,7$ & $437,8 \pm 10,8^{*}$ & $401,0 \pm 6,6$ & $381,4 \pm 7,7$ \\
\hline
\end{tabular}

Os valores são apresentados como média aritmética $\pm E P M{ }^{*} p<0,05$; $*^{*} p=0,001 ;{ }^{* * *} p=0,0005$ comparados com seus respectivos controles de acordo com o teste $t$ de Student. $n=12$.

SHR

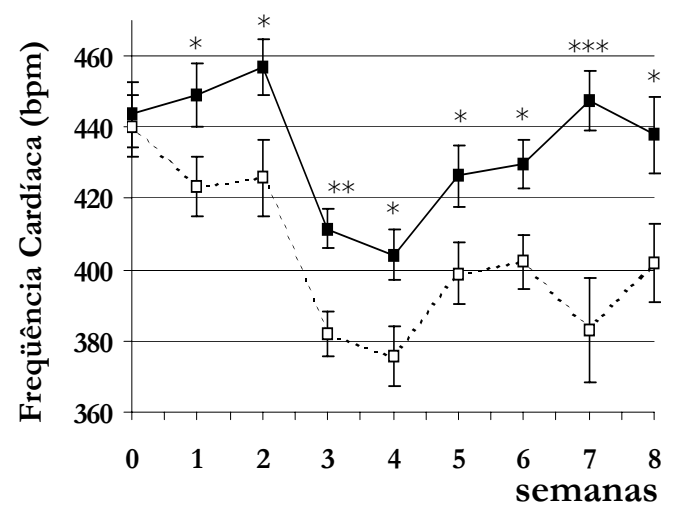

WKY

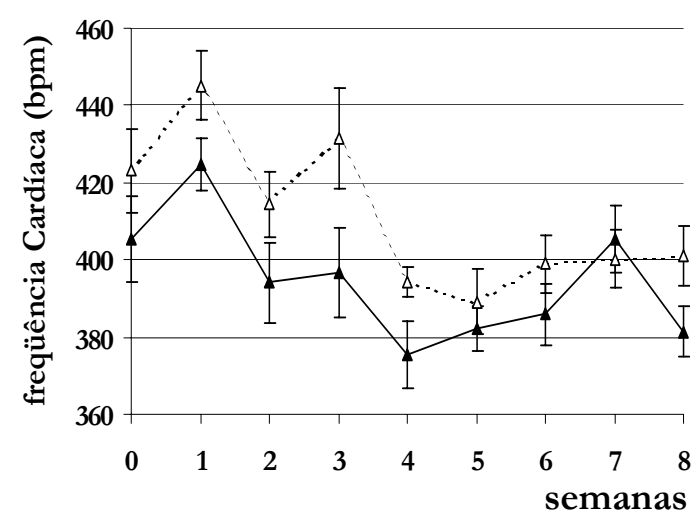

FIGURA 15. Variação da freqüência cardíaca, em batimentos por minuto, dos ratos espontaneamente hipertensos (SHR) e normotensos Wistar Kyoto (WKY) tratados com nicotina (linha contínua) ou placebo (linha tracejada) ao longo de 8 semanas. Os valores são apresentados como média aritmética $\pm E P M{ }^{*} p<0,05 ; *^{*} p=0,001 ; *^{* *} p=0,0005$ comparados com seus respectivos controles a cada semana de acordo com o teste t de Student. $n=12$. 


\subsection{Sistema Catecolaminérgico}

\subsubsection{Imunohistoquímica}

O tratamento crônico com nicotina promoveu aumento na imunorreatividade da tirosina hidroxilase no NTS e PVN dos ratos tratados com nicotina. Somente os ratos normotensos tratados com nicotina apresentaram alteração (aumento) na intensidade da imunorreatividade à TH na VLM. Ao passo que somente nos ratos SHR tratados com nicotina houve diminuição na área ocupada pela imunorreatividade à TH no locus coeruleus (Tabela 6 e Figura 16). A área imunorreativa à TH no LC de SHR é significantemente maior que em WKY nas condições basais (Tabela 6 e Figura 16).

Foi observado também que tanto o tratamento com nicotina quanto a linhagem influenciam a imunorreatividade à $\mathrm{TH}$ nos núcleos analisados, assim como há interação entre estes dois fatores na expressão da proteína (Tabela 6 e Figura 16).

A figura 17 exemplifica o padrão de marcação imunohistoquímico nas áreas de estudo e os perfis considerados para quantificação. 
Tabela 6. spMGV (unidades arbitrárias) e área (em micrômetros quadrados) ocupada pela imunorreatividade a tirosina hidroxilase no núcleo do trato solitário (NTS), medula oblonga ventrolateral (VLM), locus coeruleus (LC) e núcleo paraventricular hipotalâmico (PVN) de ratos espontaneamente hipertensos (SHR) e Wistar Kyoto (WKY) submetidos a tratamento crônico com nicotina ou placebo.

\begin{tabular}{|c|c|c|c|c|c|c|}
\hline & & & NTS $^{1}$ & $\mathrm{VLM}^{2}$ & $\mathbf{L C}^{3}$ & $\mathbf{P V N}^{4}$ \\
\hline \multirow{4}{*}{$\begin{array}{l}\text { Área } \\
\left(\mu \mathrm{m}^{2}\right)\end{array}$} & \multirow{2}{*}{ SHR } & Placebo & $3190,0 \pm 329,4$ & $2392,0 \pm 180,8$ & $8917,0 \pm 160,4$ & $1507,0 \pm 109,0$ \\
\hline & & Nicotina & $4277,0 \pm 279,1 *$ & $2524,0 \pm 98,4$ & $7816,0 \pm 473,5^{*}$ & $1997,0 \pm 140,3^{*}$ \\
\hline & \multirow{2}{*}{$\mathbf{W K Y} \mathbf{Y}^{\#}$} & Placebo & $3009,0 \pm 121,5$ & $2285,0 \pm 219,0$ & $6639,0 \pm 547,5$ & $1228,0 \pm 146,9$ \\
\hline & & Nicotina & $3717,0 \pm 208,3 *$ & $2646,0 \pm 120,3$ & $7162,0 \pm 474,8$ & $1291,0 \pm 163,2$ \\
\hline \multirow{4}{*}{$\begin{array}{l}\text { spMGV } \\
\text { (u.a.) }\end{array}$} & \multirow{2}{*}{ SHR } & Placebo & $43,00 \pm 5,09$ & $51,32 \pm 3,19$ & $94,04 \pm 4,28$ & $41,95 \pm 3,28$ \\
\hline & & Nicotina & $64,45 \pm 4,40 *$ & $57,05 \pm 2,76$ & $95,85 \pm 2,43$ & $55,68 \pm 3,08^{*}$ \\
\hline & \multirow{2}{*}{ WKY } & Placebo & $55,02 \pm 3,92$ & $49,97 \pm 1,53$ & $85,58 \pm 1,99$ & $41,20 \pm 1,92$ \\
\hline & & Nicotina & $51,49 \pm 6,79$ & $58,48 \pm 2,15^{*}$ & $89,22 \pm 1,81$ & $48,09 \pm 1,87 *$ \\
\hline
\end{tabular}

Os valores são apresentados como média aritmética $\pm E P M{ }^{*} p<0,05$ comparados com o placebo da mesma linhagem, ${ }^{\#} p<0,05$ comparado com placebo SHR, segundo a análise de variância de 2 vias (2-way ANOV A) seguida do pós-teste de Bonferroni. 1=o tratamento com nicotina influencia a área da imunorreatividade e há interação entre linhagem $e$ tratamento para a intensidade da imunorreatividade. $2=0$ tratamento com nicotina influencia a intensidade da imunorreatividade; $3=$ a linhagem influencia tanto a área quanto a intensidade da imunorreatividade; $4=$ a linhagem influencia a área e o tratamento influencia a intensidade da marcação imunorreativa, segundo a análise de variância de 2 vias. $n=6$. 

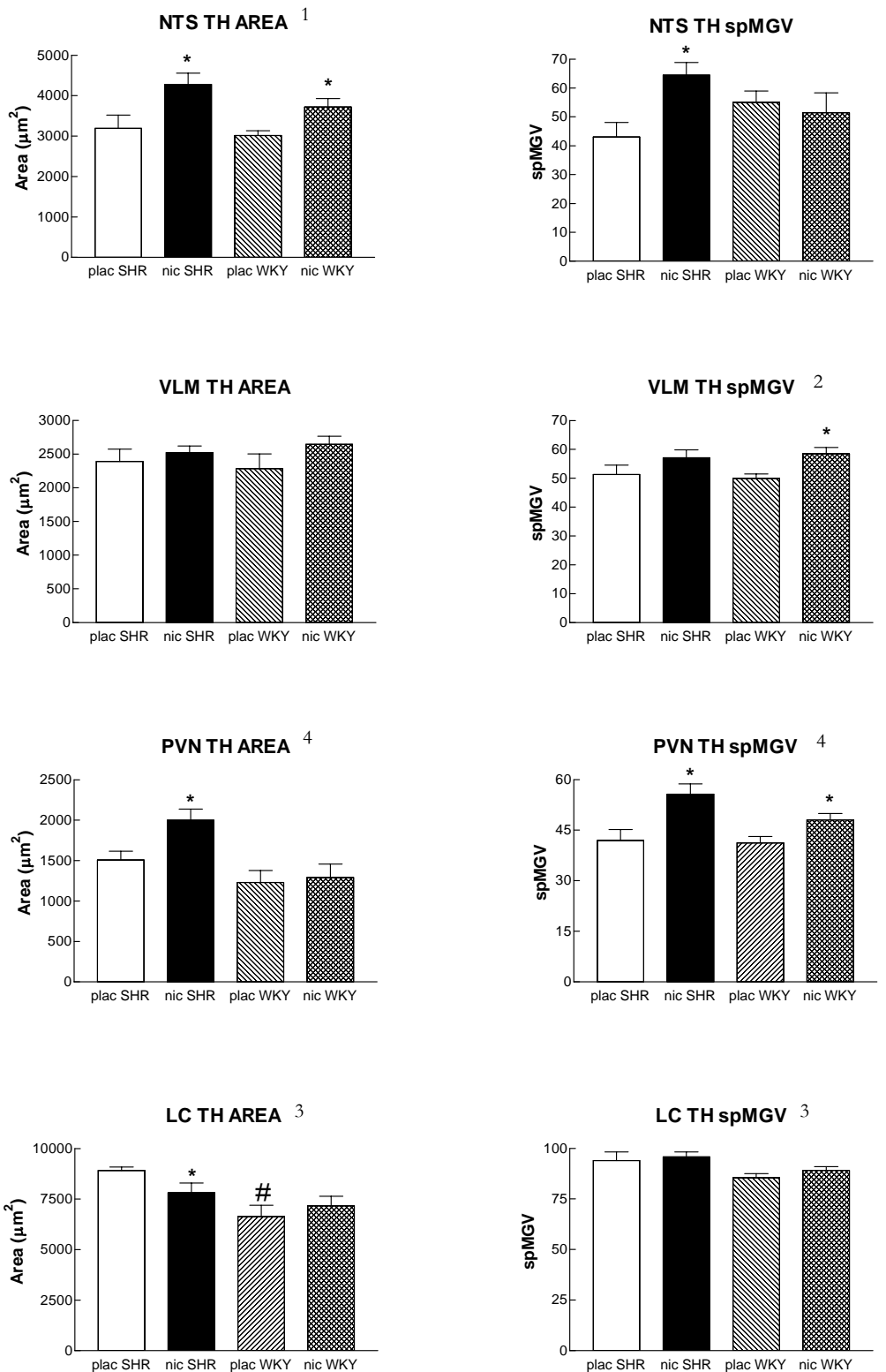

FIGURA 16. spMGV (unidades arbitrárias) e área ocupada pela imunorreatividade à tirosina hidroxilase no núcleo do trato solitário (NTS), medula oblonga ventrolateral (VLM), núcleo paraventricular hipotalâmico $(\mathrm{PVN})$ e locus coeruleus (LC) de ratos espontaneamente hipertensos (SHR) e Wistar Kyoto (WKY) submetidos a tratamento crônico com nicotina (nic) ou placebo (plac). Os valores são apresentados como média aritmética $\pm E P M .{ }^{*} p<0,05$ comparados com o placebo da mesma linhagem; ${ }^{*}<<0,05$ comparado com SHR placebo, segundo a análise de variância de 2 vias (2-way ANOVA) seguido do pós-teste de Bonferroni. $1=0$ tratamento com nicotina influencia a área da imunorreatividade e há interação entre linhagem e tratamento para a intensidade da imunorreatividade. 2=0 tratamento com nicotina influencia a intensidade da imunorreatividade; $3=$ a linhagem influencia tanto a área quanto a intensidade da imunorreatividade; $4=$ a linhagem influencia a área e o tratamento influencia a intensidade da marcação imunorreativa, segundo a análise de variancia de 2 vias. $n=6$. 

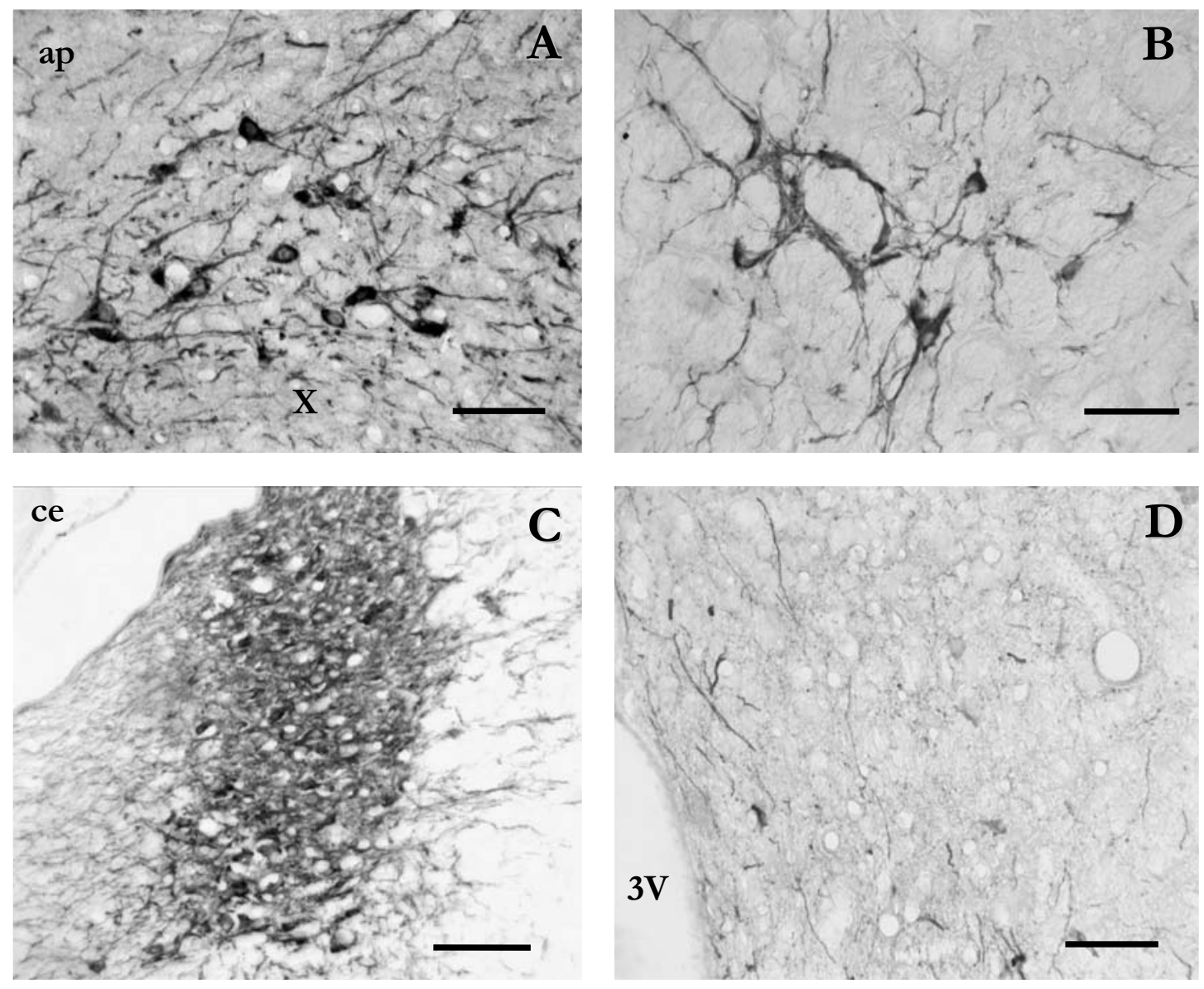

FIGURA 17. Fotomicrografias digitais representativas ilustrando o padrão de marcação da imunorreatividade à tirosina hidroxilase no núcleo do trato solitário (A), medula oblonga ventrolateral $(\mathbf{B})$, locus coeruleus $(\mathbf{C})$ e núcleo paraventricular do hipotálamo (D). Abreviaturas: ap=área postrema, 3V= terceiro ventrículo, $c e=$ cerebelo. Barra de escala $=50 \mu \mathrm{m}$. 


\subsubsection{Hibridização in situ}

O tratamento crônico com nicotina promoveu aumento na expressão do RNAm da tirosina hidroxilase no NTS, VLM e LC de ratos SHR, e no PVN dos WKY. Entretanto, no LC dos ratos WKY tratados com nicotina houve diminuição da expressão do RNAm da $\mathrm{TH}$, não havendo alteração dos níveis deste RNAm nos demais núcleos analisados (Tabela 7 e Figura 18).

A expressão do RNAm da TH sofre influência da linhagem, do tratamento com nicotina e da interação entre estes 2 parâmetros (Tabela 7 e Figura 18). Foi detectado também que a quantidade de RNAm da TH é maior no LC dos ratos SHR comparados com WKY após o tratamento crônico com nicotina, assim como no PVN dos ratos hipertensos pode ser encontrada mais TH que em WKY tanto em condições basais quanto após tratamento com nicotina (Tabela 7 e Figura 18).

A figura 19 exemplifica o padrão de marcação no filme radioautográfico promovida pela sonda complementar ao RNAm da TH nos núcleos encefálicos responsáveis pelo controle cardiovascular.

O RNAm do receptor alfa2-adrenérgico também foi estudado sendo que a exposição crônica à nicotina promoveu diminuição dos níveis deste RNAm na VLM, LC e PVN de ratos WKY. Não foram observadas alterações no RNAm do receptor alfa2 adrenérgico no NTS de ratos WKY, nem tão pouco no NTS, VLM e PVN de SHR após tratamento crônico com nicotina (Tabela 8 e Figura 20).

Tanto o tratamento com nicotina quanto a linhagem influenciam, separadamente, a expressão do RNA do receptor $\alpha 2$-adrenérgico (Tabela 8 e Figura 20).

O padrão de marcação do RNAm dos receptores alfa2-adrenérgicos nas áreas estudadas está apresentado na figura 21. 

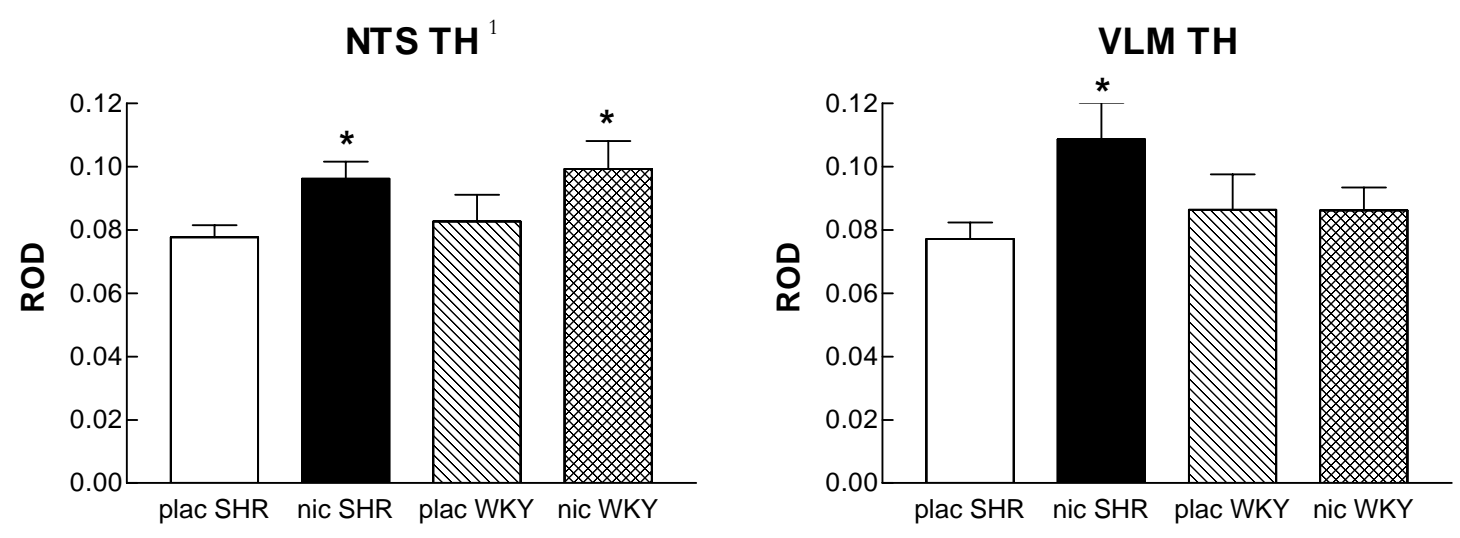

\section{PVN TH $^{3}$}

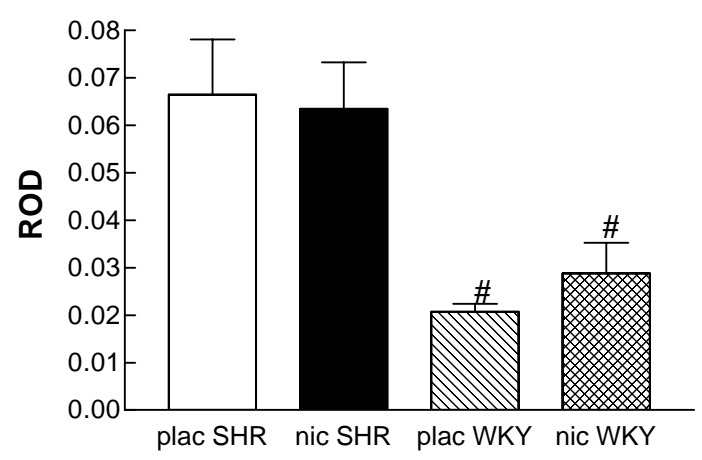

LC TH $^{2}$

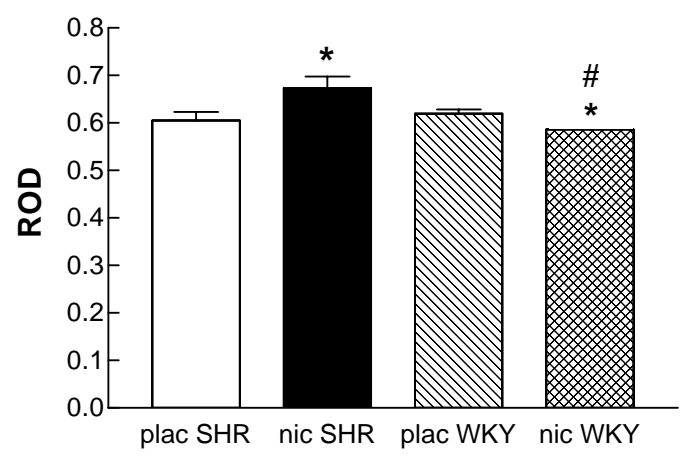

FIGURA 18. Histogramas ilustrando a densidade óptica relativa (ROD) da marcação, no filme radiosensível, promovida pela sonda radioativa complementar ao RNAm da tirosina hidroxilase no núcleo do trato solitário (NTS), medula ventrolateral (VLM), locus coeruleus (LC) e núcleo paraventricular do hipotálamo (PVN) de ratos espontaneamente hipertensos (SHR) e Wistar Kyoto (WKY) submetidos a tratamento crônico com nicotina (nic) ou placebo (pla). Os valores são apresentados como média aritmética土 EPM. ${ }^{*} p<0,05$; comparados com o placebo da mesma linhagem; ${ }^{\#}<0,05$ comparados com SHR na mesma situação de tratamento, segundo análise de variância de 2 vias (2-way ANOVA). A expressão do RNAm depende dos seguintes fatores nos núcleos analisados: $1=$ do tratamento com nicotina, $2=$ da linhagem e da interação entre linhagem e tratamento $e$ $3=$ da linhagem, segundo a análise de variância de 2 vias . $n=6$. 

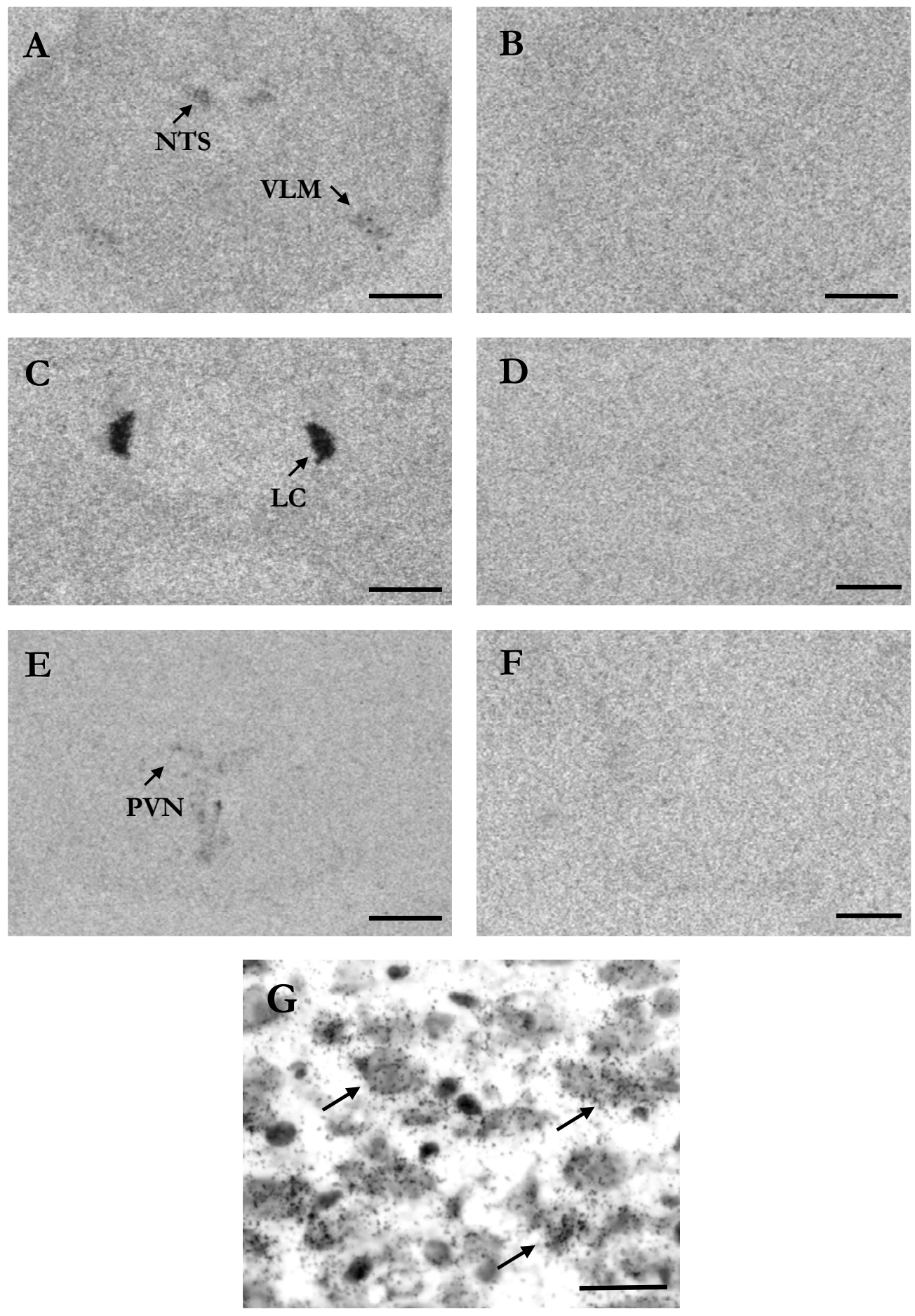

FIGURA 19. Imagens representativas ilustrando a marcação, no filme radiosensível, promovida pela sonda radioativa complementar ao RNAm da tirosina hidroxilase no núcleo do trato solitário (NTS), medula ventrolateral (VLM) (A), locus coeruleus (LC) (C) e núcleo paraventricular do hipotálamo $(\mathbf{E})$, assim como o controle de especificidade da sonda deslocada com excesso de sonda não marcada $(\mathbf{B}, \mathbf{D}$ e $\mathbf{F})$. Em $\mathbf{G}$ tem-se um exemplo da localização celular da marcação no LC. Barra de escala $=1 \mathrm{~mm}$ e $30 \mu \mathrm{m}(\mathbf{G})$. 
Tabela 8. Densidade Óptica Relativa (ROD em unidades arbitrárias) da marcação, no filme radiosensível, promovida pela sonda radioativa complementar ao RNAm do receptor alfa2-adrenérgico no núcleo do trato solitário (NTS), medula ventrolateral (VLM), locus coeruleus (LC) e núcleo paraventricular do hipotálamo (PVN) de ratos espontaneamente hipertensos (SHR) e Wistar Kyoto (WKY) submetidos a tratamento crônico com nicotina ou placebo.

\begin{tabular}{cccccc}
\hline & & NTS $^{1}$ & VLM $^{2}$ & LC & PVN \\
\hline \multirow{2}{*}{ SHR } & Placebo & $0,1084 \pm 0,0193$ & $0,1523 \pm 0,0391$ & $0,4752 \pm 0,02178$ & $0,0481 \pm 0,0043$ \\
& Nicotina & $0,1184 \pm 0,0167$ & $0,1653 \pm 0,0317$ & $0,4557 \pm 0,0331$ & $0,0501 \pm 0,0087$ \\
\hline \multirow{2}{*}{ WKY } & Placebo & $0,0873 \pm 0,0072$ & $0,1893 \pm 0,0237$ & $0,4891 \pm 0,0210$ & $0,0464 \pm 0,0051$ \\
& Nicotina & $0,0823 \pm 0,0064$ & $0,1159 \pm 0,0199 *$ & $0,4255 \pm 0,0173^{*}$ & $0,0351 \pm 0,0014^{*}$ \\
\hline
\end{tabular}

Os valores são apresentados como média aritmética $\pm E P M .{ }^{*} p<0,05$ comparados com 0 placebo da mesma linhagem segundo análise de variância de 2 vias (2-way ANOVA). A expressão do RNAm depende dos seguintes fatores nos núcleos analisados: $1=$ da linhagem $e$ $2=$ do tratamento com nicotina, segundo a análise de variância de 2 vias. $n=6$. 

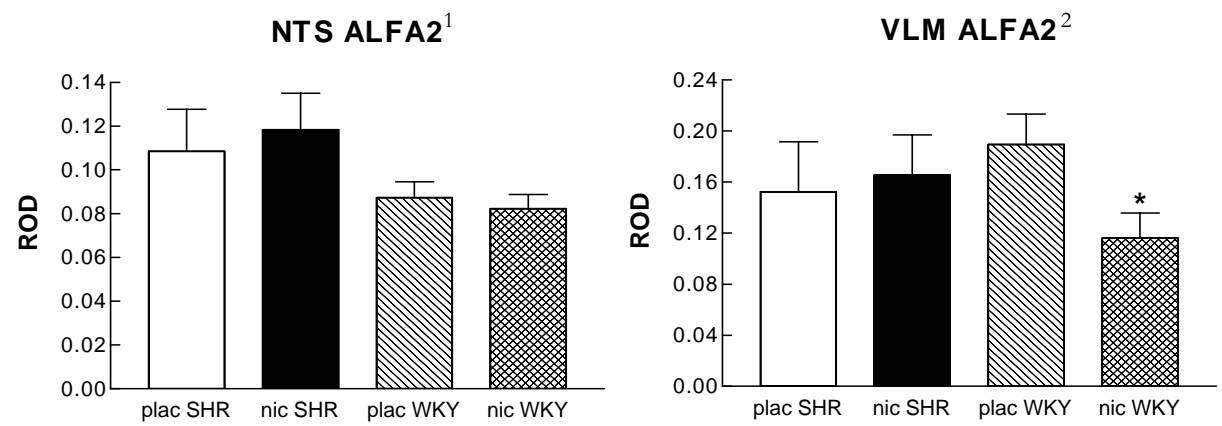

PVN ALFA2

LC ALFA2
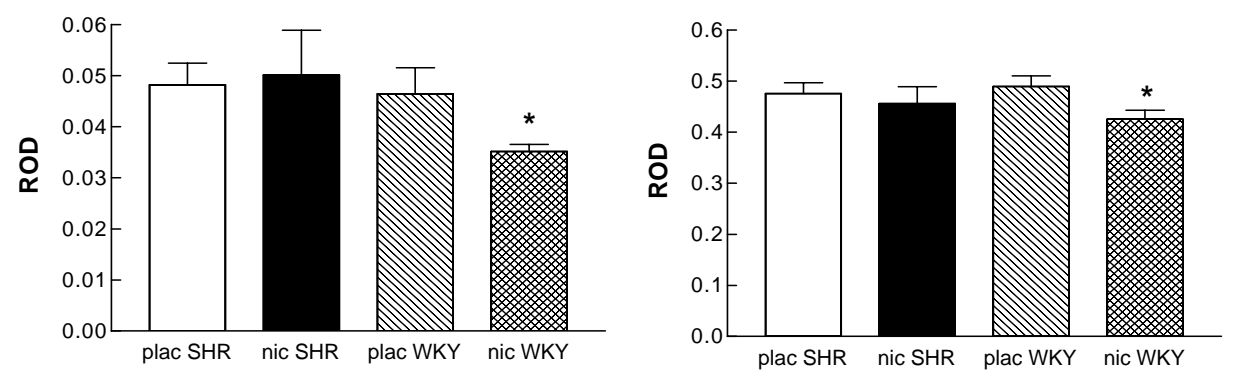

FIGURA 20. Histogramas ilustrando a densidade óptica relativa (ROD) da marcação, no filme radiosensível, promovida pela sonda radioativa complementar ao RNAm do receptor alfa2-adrenérgico no núcleo do trato solitário (NTS), medula ventrolateral (VLM), locus coeruleus(LC) e núcleo paraventricular do hipotálamo (PVN) de ratos espontaneamente hipertensos (SHR) e Wistar Kyoto (WKY) submetidos a tratamento crônico com nicotina (nic) ou placebo (pla). Os valores são apresentados como média aritmética \pm $E P M .{ }^{*} p<0,05$ comparados com o placebo da mesma linhagem segundo análise de variancia de 2 vias (2-way ANOVA). A expressão do RNAm depende dos seguintes fatores nos núcleos analisados: $1=$ da linhagem e $2=$ do tratamento com nicotina, segundo a análise de variância de 2 vias. $n=6$. 

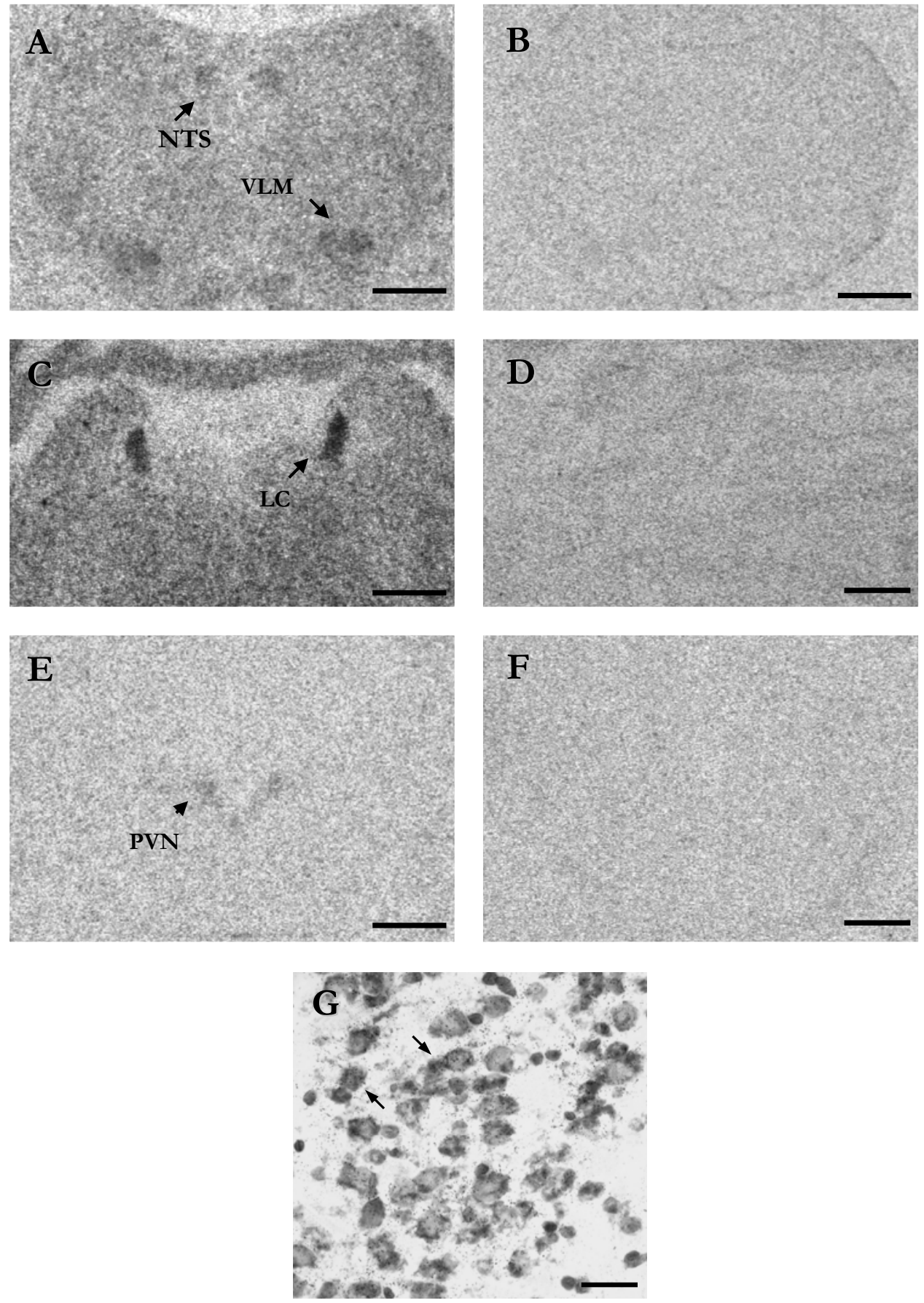

FIGURA 21. Imagens representativas ilustrando a marcação, no filme radiosensível, promovida pela sonda radioativa complementar ao RNAm do receptor alfa2-adrenérgico no núcleo do trato solitário (NTS), medula ventrolateral (VLM) (A), locus coeruleus (LC) (C) e núcleo paraventricular do hipotálamo (E), assim como o controle de especificidade da sonda deslocada com excesso de sonda não marcada $(\mathbf{B}, \mathbf{D}$ e $\mathbf{F})$. Em $\mathbf{G}$ tem-se um exemplo da localização celular da marcação no LC. Barra de escala=1mm e $50 \mu \mathrm{m}(\mathbf{G})$. 


\subsubsection{Análise da Ligação}

O tratamento com nicotina não promoveu alteração da ligação do $\left[{ }^{3} \mathrm{H}\right] \mathrm{RX}$ aos receptores $\alpha_{2}$-adrenérgicos nos núcleos encefálicos responsáveis pela regulação cardiovascular (Tabela 9 e Figura 22). A análise de variância de duas vias permitiu também a certificação de que nem a linhagem nem o tratamento crônico com nicotina influenciam a ligação destes receptores.

O padrão de marcação radioativa nos núcleos em estudo está representado na figura 23, assim como o controle de especificidade do ligante.

Tabela 9. Ligação do $\left[{ }^{3} \mathrm{H}\right] \mathrm{RX}-821002$ (fmol.mg proteína ${ }^{-1}$ ) aos receptores $\alpha_{2}$ adrenérgicos no núcleo do trato solitário (NTS), medula oblonga ventrolateral (VLM), locus coeruleus (LC) e núcleo paraventricular hipotalâmico (PVN) de ratos espontaneamente hipertensos (SHR) e Wistar Kyoto (WKY) submetidos a tratamento crônico com nicotina ou placebo.

\begin{tabular}{cccccc}
\hline & & NTS & VLM & LC & PVN \\
\hline \multirow{2}{*}{ SHR } & Placebo & $116,10 \pm 4,34$ & $94,52 \pm 7,42$ & $190,00 \pm 10,98$ & $75,35 \pm 7,21$ \\
& Nicotina & $122,20 \pm 9,51$ & $92,11 \pm 7,93$ & $186,70 \pm 10,20$ & $92,75 \pm 9,91$ \\
\hline \multirow{2}{*}{ WKY } & Placebo & $110,90 \pm 8,01$ & $87,63 \pm 7,229$ & $185,60 \pm 4,359$ & $89,02 \pm 12,29$ \\
& Nicotina & $106,20 \pm 9,34$ & $83,85 \pm 6,78$ & $194,50 \pm 11,17$ & $73,13 \pm 6,20$ \\
\hline
\end{tabular}

Os valores são apresentados como média aritmética EPM. Empregou-se a análise de variância de 2 vias (2-way-ANOV A) para a análise estatística. $n=6$. 

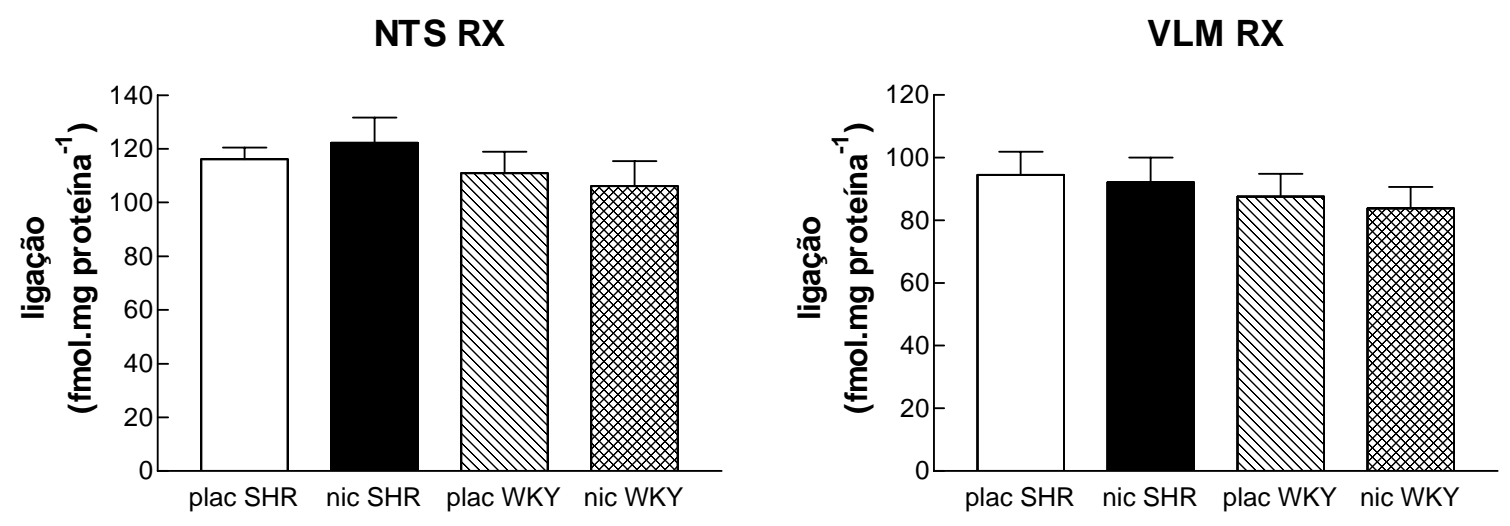

\section{LC RX}

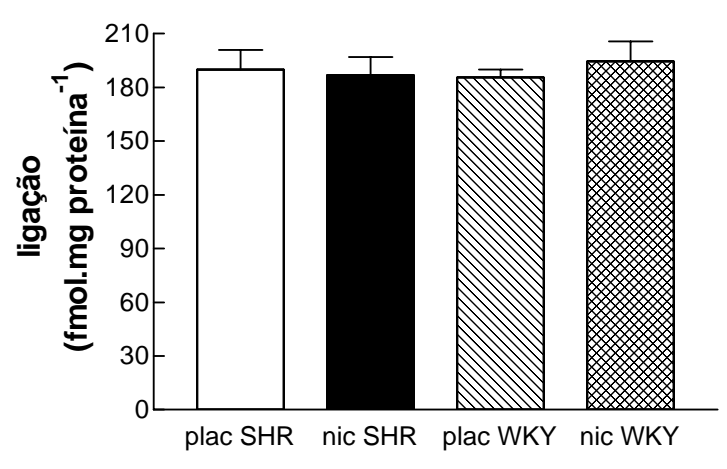

PVN RX

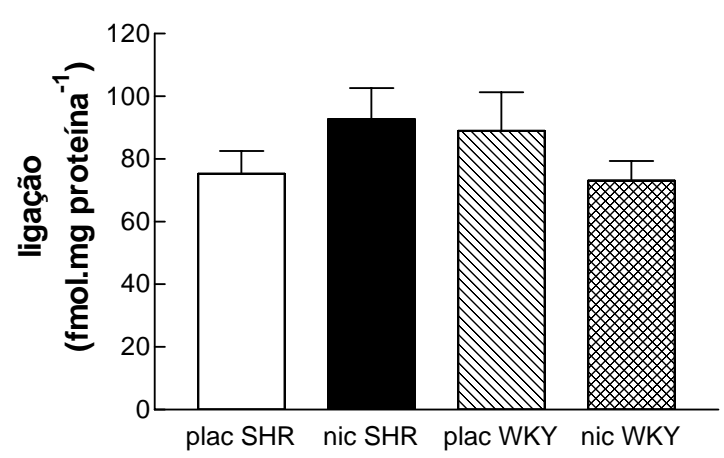

FIGURA 22. Ligação do $\left[{ }^{3} \mathrm{H}\right] \mathrm{RX}-821002$ (fmol.mg proteína ${ }^{-1}$ ) aos receptores $\alpha_{2}$ adrenérgicos no núcleo do trato solitário (NTS), medula oblonga ventrolateral (VLM), locus coeruleus (LC) e núcleo paraventricular hipotalâmico (PVN) de ratos espontaneamente hipertensos (SHR) e Wistar Kyoto (WKY) submetidos a tratamento crônico com nicotina (nic) ou placebo (plac). Os valores são apresentados como média aritmética E EPM. Empregou-se a análise de variância de 2 vias (2-way-ANOV A) para a análise estatística. $n=6$ 

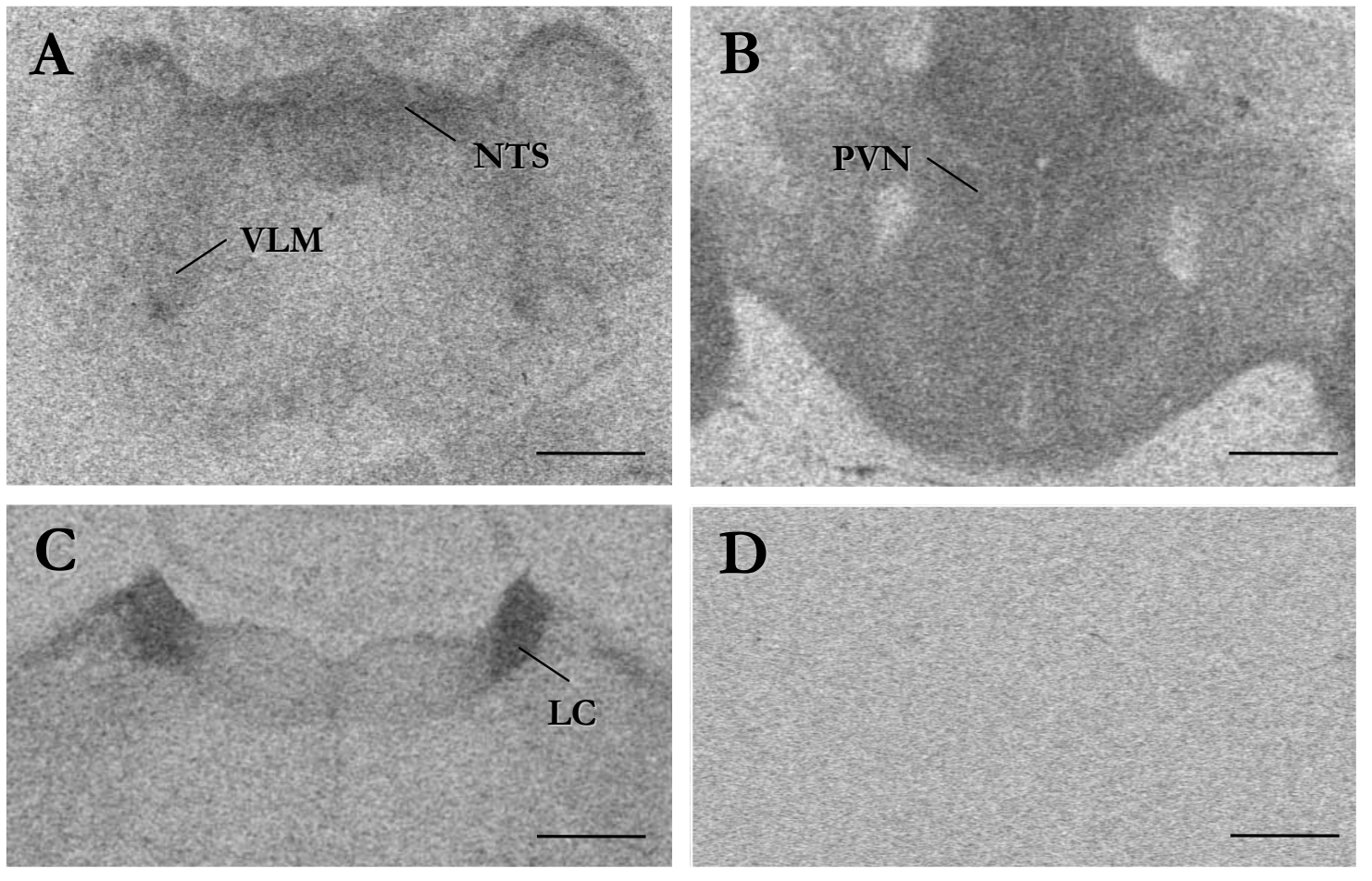

FIGURA 23. Imagens representativas do filme radioautográfico mostrando o padrão de marcação dos receptores $\alpha_{2}$-adrenérgicos pelo ligante ${ }^{3} \mathrm{H}$ RX no núcleo do trato solitário (NTS) e medula oblonga ventrolateral (VLM) (A), núcleo paraventricular do hipotálamo (PVN) (B) e locus coeruleus (LC) (C). Em $\mathbf{D}$ tem-se a ausência de marcação específica devido ao deslocamento do ligante radioativo por noradrenalina. Abreviaturas: 12=núcleo hipoglosso, $\mathrm{ce}=$ cerebelo, $\mathrm{f}=$ fórnix, opt $=$ trato óptico. Barra de escala $=1 \mathrm{~mm}$. 


\subsection{Sistema do Neuropeptídeo Y}

\subsubsection{Imunobistoquímica}

A imunorreatividade ao NPY encontrou-se aumentada no NTS e PVN de ratos SHR tratados com nicotina, no entanto os ratos WKY só apresentaram aumento desta imunorreatividade no PVN (Tabela 10 e Figura 24).

Na situação basal, a expressão do NPY encontra-se diminuída no NTS de ratos SHR em comparação com os ratos WKY. No PVN, a intensidade da imunorreatividade do NPY em ratos SHR tratados com nicotina é significativamente maior do que em WKY na mesma situação (Tabela 10 e Figura 25).

$\mathrm{Na}$ figura 24 estão representados os padrões imunorreativos analisados. 
Tabela 10. spMGV (unidades arbitrárias) e área (em micrômetros quadrados) ocupada pela imunorreatividade ao Neuropeptídeo $\mathrm{Y}$ no núcleo do trato solitário (NTS), medula oblonga ventrolateral (VLM), locus coeruleus (LC) e núcleo paraventricular hipotalâmico (PVN) de ratos espontaneamente hipertensos (SHR) e Wistar Kyoto (WKY) submetidos a tratamento crônico com nicotina ou placebo.

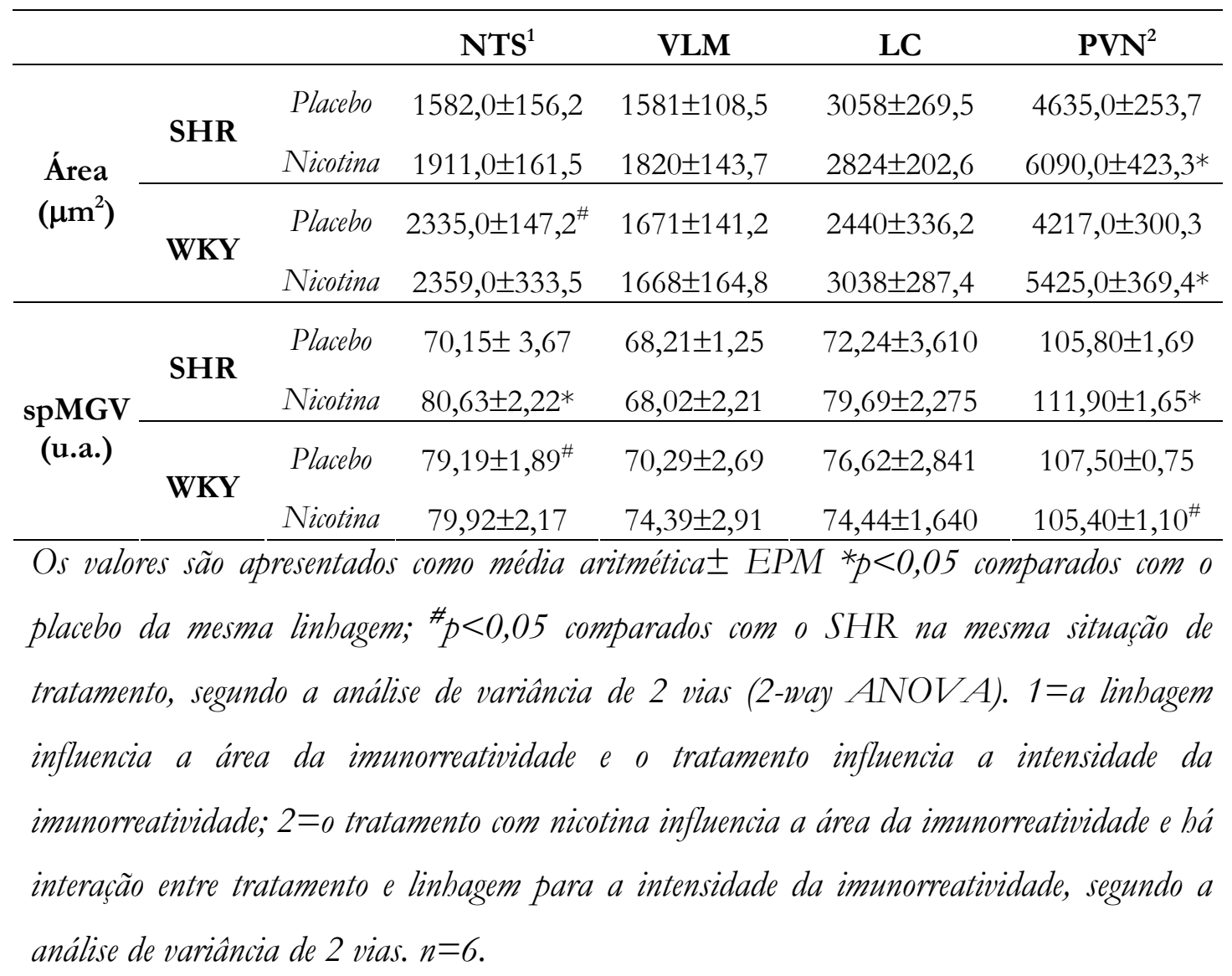




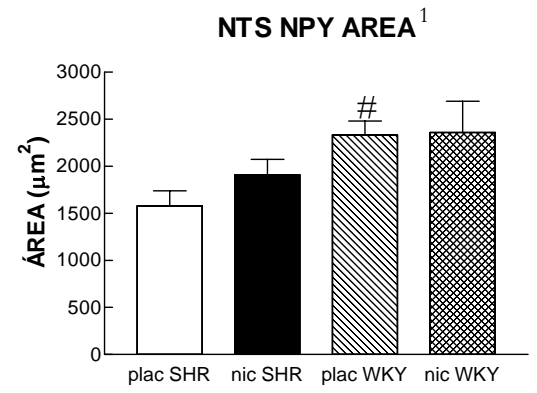

VLM NPY AREA

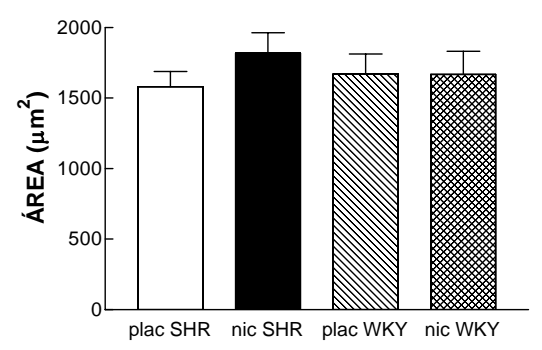

PVN NPY AREA ${ }^{2}$

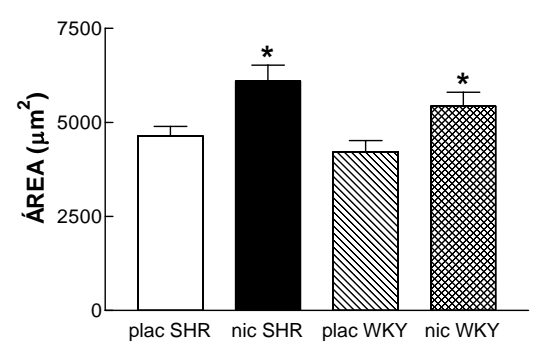

LC NPY AREA

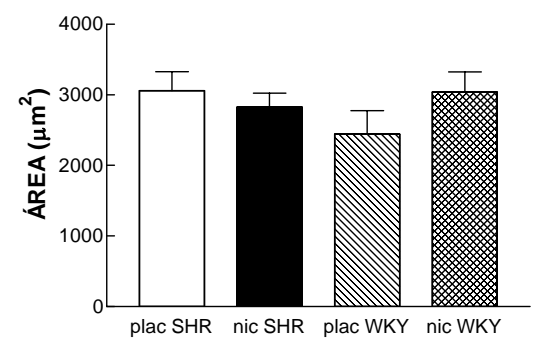

NTS NPY spMGV ${ }^{1}$

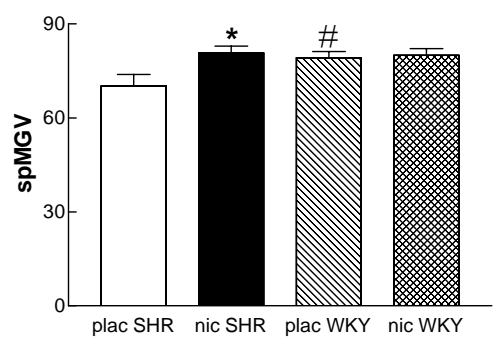

VLM NPY spMGV

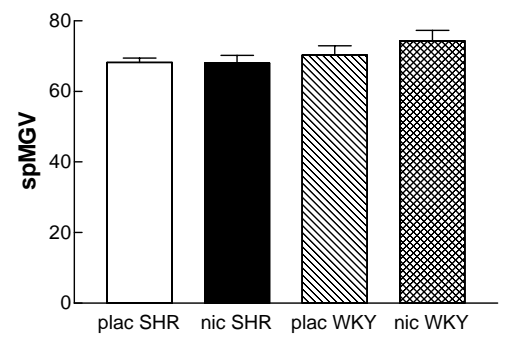

PVN NPY spMGV ${ }^{2}$

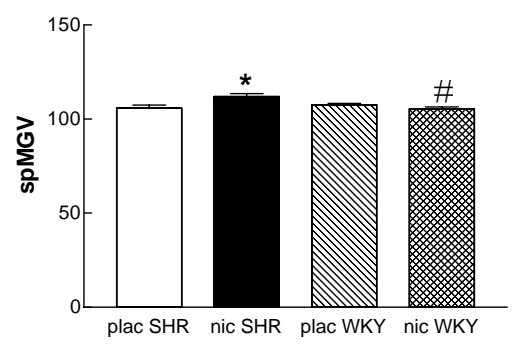

LC NPY spMGV

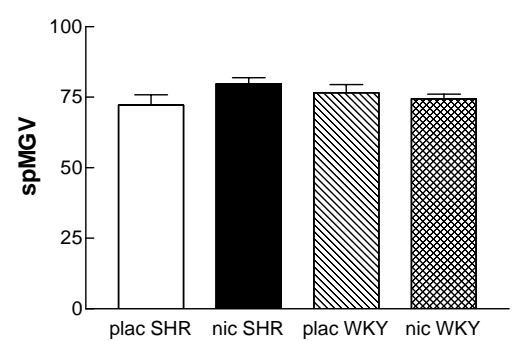

FIGURA 24. spMGV (unidades arbitrárias) e área ocupada pela imunorreatividade ao Neuropeptídeo Y (NPY) no núcleo do trato solitário (NTS), medula oblonga ventrolateral (VLM), núcleo paraventricular hipotalâmico (PVN) e locus coeruleus (LC) de ratos espontaneamente hipertensos (SHR) e Wistar Kyoto (WKY) submetidos a tratamento crônico com nicotina (nic) ou placebo (plac). Os valores são apresentados como média aritmética $\pm E P M{ }_{p}^{*}<0,05$ comparados com o placebo da mesma linhagem; ${ }_{p}<0,05$ comparados com o SHR na mesma situação de tratamento, segundo a análise de variância de 2 vias (2-way $A N O V A) .1=a$ linhagem influencia a área da imunorreatividade e 0 tratamento influencia a intensidade da imunorreatividade; $2=0$ tratamento com nicotina influencia a área da imunorreatividade e há interação entre tratamento e linhagem para a intensidade da imunorreatividade, segundo a análise de variancia de 2 vias $n=6$. 

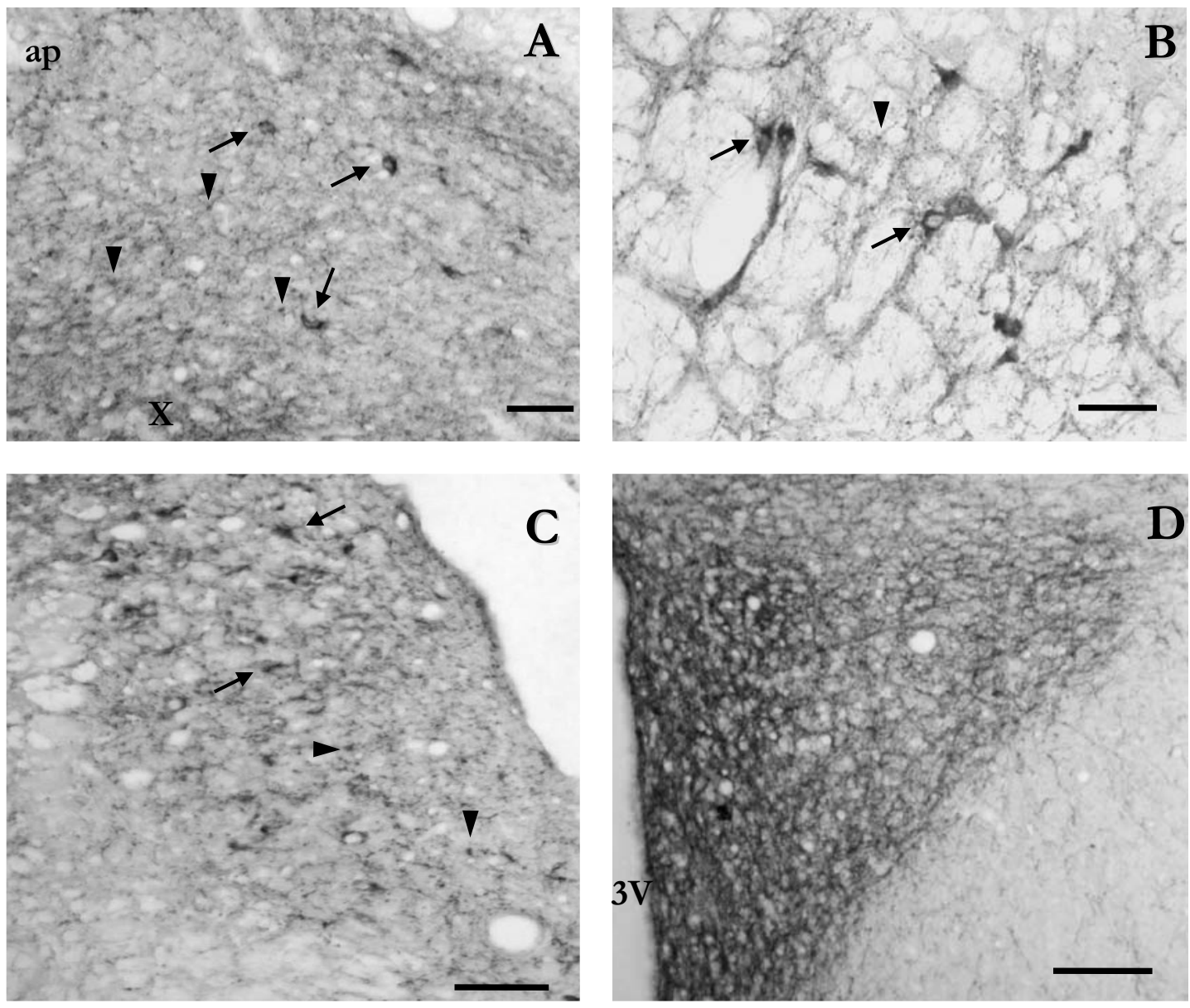

FIGURA 25. Fotomicrografias digitais representativas ilustrando o padrão de marcação da imunorreatividade ao neuropeptídeo $\mathrm{Y}$ no núcleo do trato solitário (A), medula oblonga ventrolateral $(\mathbf{B})$, locus coeruleus $(\mathbf{C})$ e núcleo paraventricular do hipotálamo (D). Onde se encontram corpos celulares (seta) e terminais axonais (cabeça de seta), no PVN há predominância de terminais. Abreviaturas: ap=área postrema, $\mathrm{X}=$ núcleo motor dorsal do vago, $3 \mathrm{~V}=$ terceiro ventrículo, ce $=$ cerebelo. Barra de escala $=50 \mu \mathrm{m}$. 


\subsubsection{Hibridização in situ}

O tratamento crônico com nicotina não alterou os níveis de RNAm do NPY no NTS, VLM e LC tanto dos animais WKY quanto dos SHR (Tabela 11 e Figura 26). A análise estatística através do ANOVA de duas vias permitiu verificar que a expressão do NPY não sofre influência do tratamento com nicotina nem tampouco da linhagem de ratos. Na figura 27 pode-se visualizar o padrão de marcação do RNAm do NPY nos núcleos analisados neste estudo.

Tabela 11. Densidade Óptica Relativa (ROD) da marcação, no filme radiosensível, promovida pela sonda radioativa complementar ao RNAm do Neuropeptídeo Y no núcleo do trato solitário (NTS), medula oblonga ventrolateral (VLM) e locus coeruleus (LC) de ratos espontaneamente hipertensos (SHR) e Wistar Kyoto (WKY) submetidos a tratamento crônico com nicotina ou placebo.

\begin{tabular}{lcccc}
\hline & & NTS & VLM & LC \\
\hline \multirow{2}{*}{ SHR } & Placebo & $0,1174 \pm 0,0089$ & $0,2989 \pm 0,0384$ & $0,4909 \pm 0,0573$ \\
& Nicotina & $0,1130 \pm 0,0102$ & $0,3342 \pm 0,0374$ & $0,5547 \pm 0,0383$ \\
\hline \multirow{2}{*}{$\mathbf{W K Y}$} & Placebo & $0,1053 \pm 0,0121$ & $0,3126 \pm 0,0523$ & $0,4797 \pm 0,0342$ \\
& Nicotina & $0,1035 \pm 0,0086$ & $0,3500 \pm 0,0415$ & $0,4511 \pm 0,0321$ \\
\hline $\begin{array}{l}\text { Os valores são apresentados como média aritmética } \pm \text { EPM. Empregou-se a } \\
\text { análise de variância de 2 vias (2-way-ANOVA) para a análise estatística. } \\
n=6 .\end{array}$
\end{tabular}




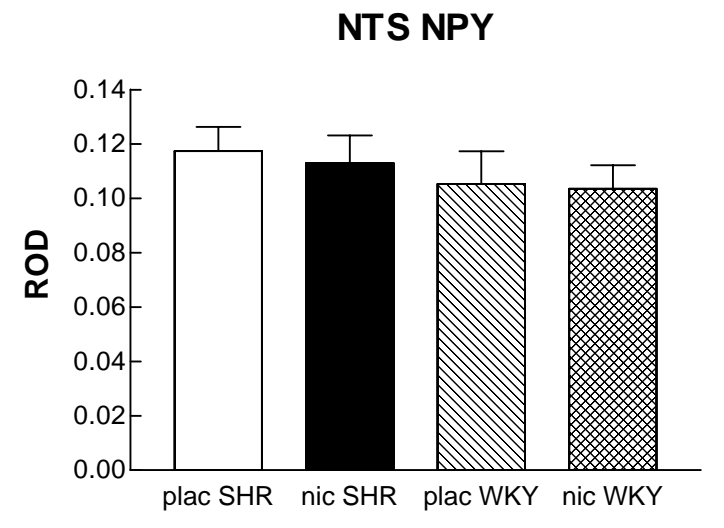

VLM NPY

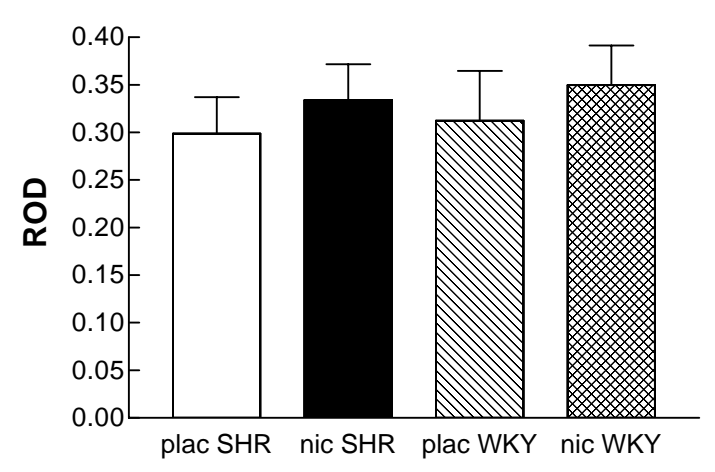

LC NPY

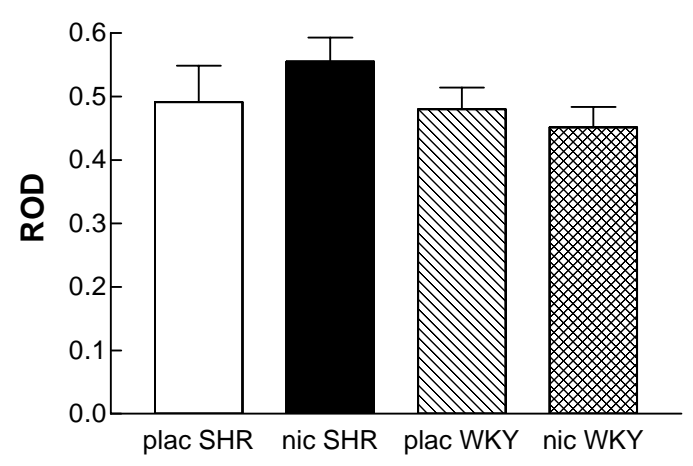

FIGURA 26. Densidade Óptica Relativa (ROD) da marcação, no filme radiosensível, promovida pela sonda radioativa complementar ao RNAm do neuropeptídeo Y (NPY) no núcleo do trato solitário (NTS), medula oblonga ventrolateral (VLM) e locus coeruleus (LC) de ratos espontaneamente hipertensos (SHR) e Wistar Kyoto (WKY) submetidos a tratamento crônico com nicotina (nic) ou placebo (plac). Os valores são apresentados como média aritmética土 EPM. Empregou-se a análise de variância de 2 vias (2-way-ANOV A) para a análise estatistica. $n=6$. 

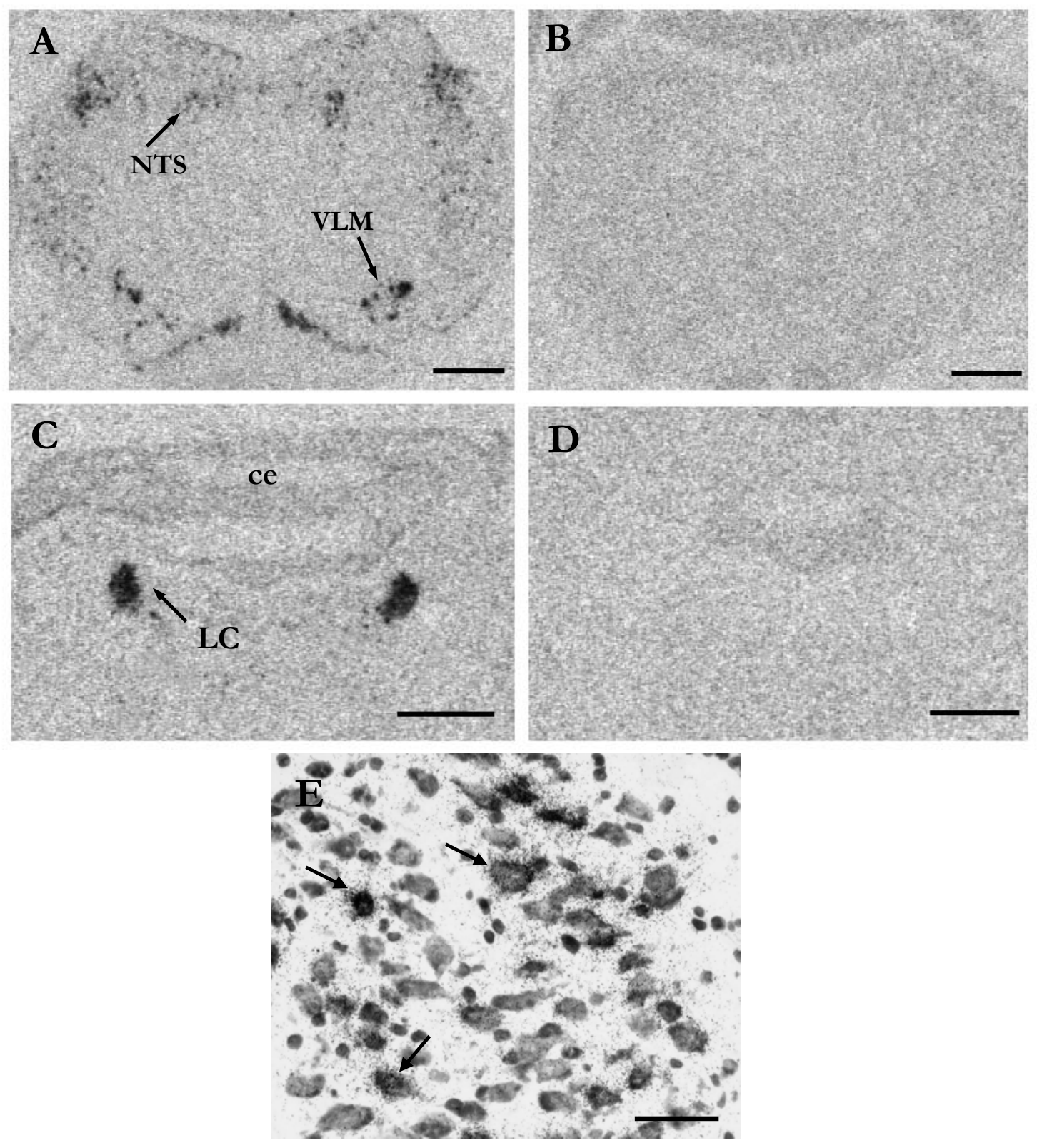

FIGURA 26. Imagens representativas da marcação, no filme radiosensível, promovida pela sonda radioativa complementar ao RNAm do neuropeptídeo Y no núcleo do trato solitário (NTS), medula oblonga ventrolateral (VLM) (A) e locus coeruleus (LC) (C). Em B e $\mathbf{D}$ tem-se o deslocamento da sonda radioativa por sonda não marcada em excesso mostrando a especificidade da marcação. Em E encontra-se um exempli da localização celular da marcação no LC. Abreviatura: ce $=$ cerebelo. Barra de escala $=1 \mathrm{~mm}$ e $50 \mu \mathrm{m}(\mathrm{E})$. 


\subsubsection{Análise da Ligação}

O tratamento com nicotina promoveu diminuição da ligação do NPY aos receptores Y1 e Y2 no NTS de ratos SHR e WKY como se pode notar na tabela 12 e figura 28.

Observou-se que a ligação dos receptores Y1 no NTS e PVN de ratos SHR é maior que em WKY na situação basal, esta diferença permanece no PVN após tratamento com nicotina (Tabela 12 e Figura 28). A ligação dos receptores de NPY sofre influência do tratamento com nicotina e da linhagem, assim como a interação entre linhagem e tratamento com nicotina modula a ligação dos receptores de NPY nos núcleos analisados. A figura 29 ilustra o padrão de marcação nos núcleos encefálicos objetos deste estudo. 
Tabela 12. Ligação do $\left[{ }^{125} \mathrm{~T}\right] \mathrm{PYY}$ (fmol.mg proteína ${ }^{-1}$ ) aos receptores Y1 e Y2 do neuropeptídeo Y no núcleo do trato solitário (NTS), e Y1 no locus coeruleus (LC) e núcleo paraventricular hipotalâmico (PVN) de ratos espontaneamente hipertensos (SHR) e Wistar Kyoto (WKY) submetidos a tratamento crônico com nicotina ou placebo.

\begin{tabular}{cccccc}
\hline \multicolumn{2}{c}{ NTS } & LC & PVN \\
\hline & \multicolumn{1}{c}{$\mathbf{1}^{1}$} & $\mathbf{Y 2}^{2}$ & $\mathbf{Y 1}^{3}$ & $\mathbf{Y 1}^{4}$ \\
\hline \multirow{2}{*}{ SHR } & Placebo & $1,9360 \pm 0,3104$ & $0,6811 \pm 0,07461$ & $0,1764 \pm 0,05513$ & $0,9862 \pm 0,1347$ \\
& Nicotina & $0,9630 \pm 0,1002^{* *}$ & $0,3094 \pm 0,1119^{*}$ & $0,2781 \pm 0,09587$ & $0,9780 \pm 0,0988$ \\
\hline \multirow{2}{*}{$\mathbf{W K Y}$} & Placebo & $1,1130 \pm 0,1372^{\#}$ & $0,7641 \pm 0,1921$ & $0,2558 \pm 0,08014$ & $0,5059 \pm 0,0599^{\#}$ \\
& Nicotina & $0,5694 \pm 0,1610^{*}$ & $0,3841 \pm 0,0417^{\mathbf{t}}$ & $0,1602 \pm 0,05086$ & $0,6085 \pm 0,0162^{\#}$ \\
\hline
\end{tabular}

Os valores são apresentados como média aritmética \pm EPM. ${ }^{*} p<0,01 ;{ }^{*} p<0,05 ;{ }^{t} p=0,06$ comparados com o placebo da mesma linhagem, ${ }^{\#} p<0,05$ comparados com o SHR na mesma situação de tratamento, segundo a análise de variância de 2 vias (2-way ANOV A). 1=a linhagem e o tratamento com nicotina, separadamente, influenciam a ligação; $2=0$ tratamento com nicotina influencia a ligação; $3=$ há interação entre linhagem e tratamento para o valor da ligação; $4=$ a linhagem influencia a ligação, segundo a análise de variância de 2 vias. $n=6$. 
NTS Y ${ }^{1}$

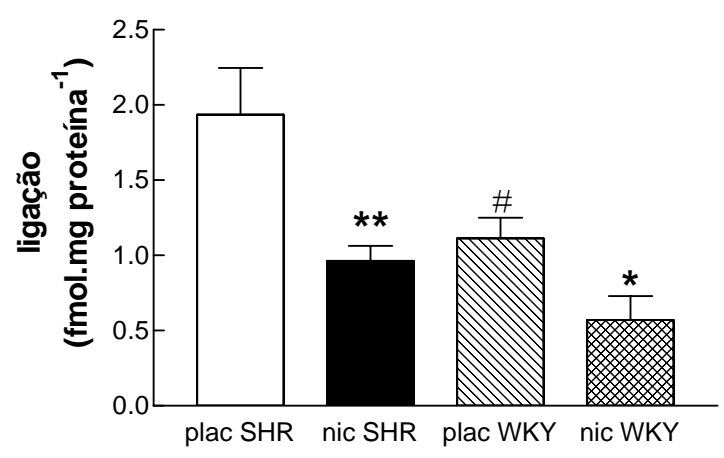

LC Y $1^{3}$

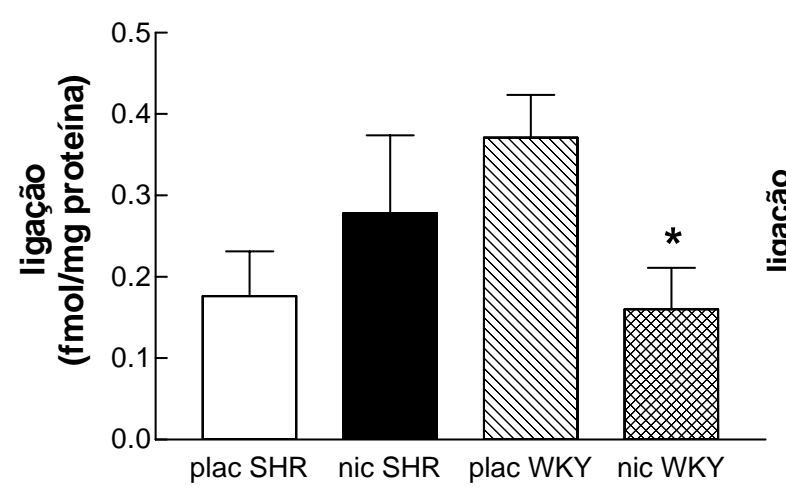

NTS Y2 ${ }^{2}$

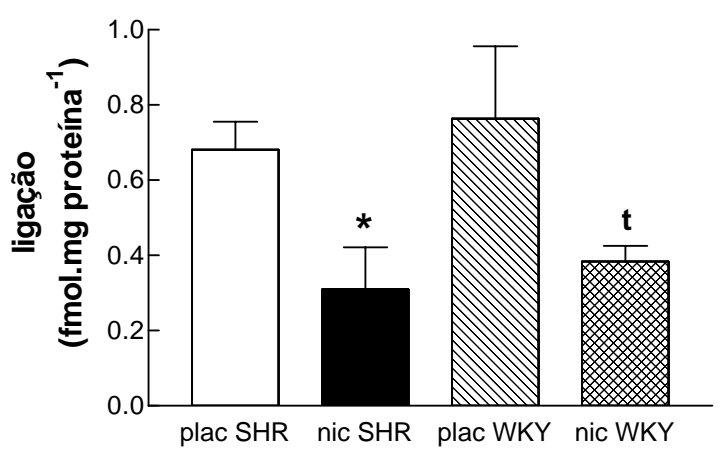

PVN Y1 ${ }^{4}$

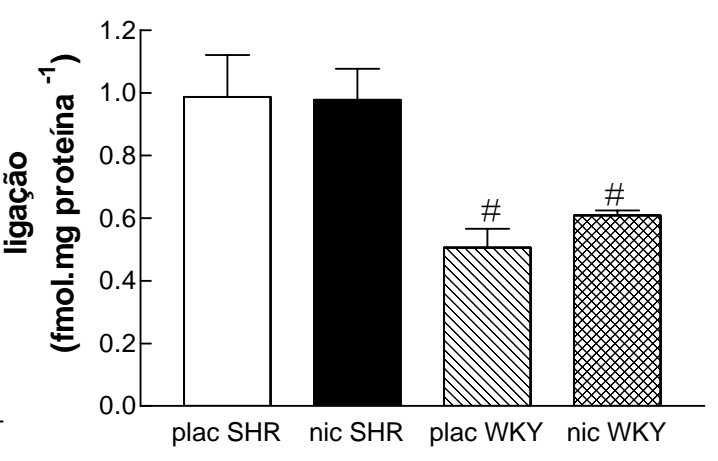

FIGURA 28. Ligação do $\left[{ }^{125} \Pi\right.$ PYY (fmol.mg proteína ${ }^{-1}$ ) aos receptores Y1 e Y2 do neuropeptídeo Y no núcleo do trato solitário (NTS), e Y1 no locus coeruleus (LC) e núcleo paraventricular hipotalâmico (PVN) de ratos espontaneamente hipertensos (SHR) e Wistar Kyoto (WKY) submetidos a tratamento crônico com nicotina (nic) ou placebo (plac). Os valores são apresentados como média aritmética $\pm E P M .{ }^{*} p<0,01 ;{ }^{*} p<0,05 ;{ }^{t} p=0,06$ comparados com o placebo da mesma linhagem, ${ }^{\#} p<0,05$ comparados com o SHR na mesma situação de tratamento, segundo a análise de variância de 2 vias (2-way $A N O V A) .1=$ a linhagem e o tratamento com nicotina, separadamente, influenciam a ligação; $2=0$ tratamento com nicotina influencia a ligação; 3=há interação entre linhagem e tratamento para o valor da ligação; $4=$ a linhagem influencia a ligação, segundo a análise de variância de 2 vias. $n=6$. 

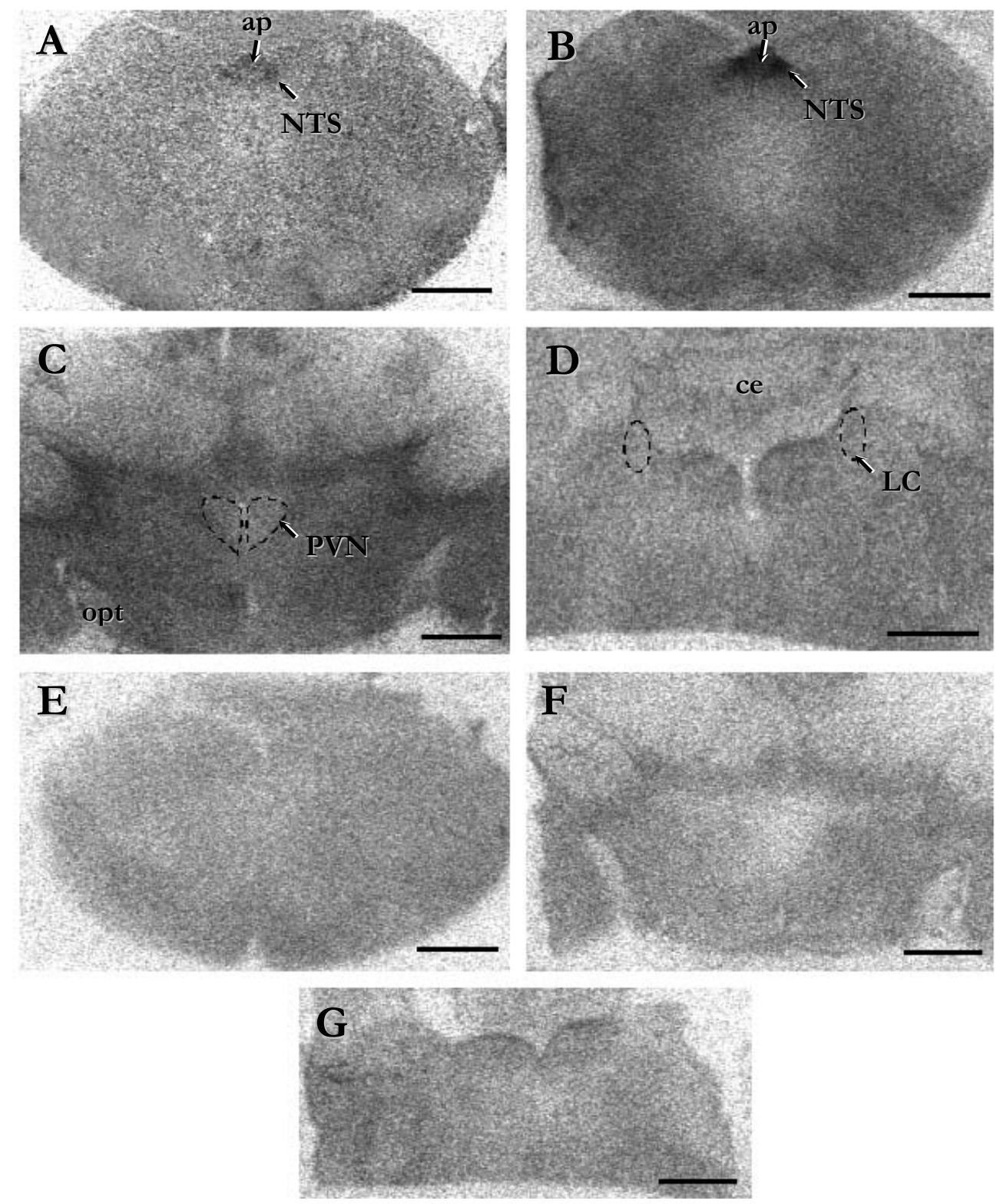

FIGURA 29. Imagens representativas do filme radioautográfico mostrando o padrão de marcação dos receptores Y2 e Y1 do Neuropeptídeo Y pelo ligante ${ }^{125}$ I PYY no núcleo do trato solitário (NTS) (A e B, respectivamente), receptores Y1 no núcleo paraventricular do hipotálamo (PVN) (C) e locus coeruleus (LC) (D). Em E, F e $\mathbf{G}$ tem-se ausência de marcação específica devido ao deslocamento do ligante radioativo por agonista Y1 (NPY [Leu ${ }^{31}$ Pro $\left.\left.^{34}\right]\right)$ e Y2 (NPY 13-36) não marcados. Barra de escala=1mm. Abreviaturas: ap=área postrema, ce=cerebelo, opt=trato óptico. 


\subsection{Sistema Angiotensinérgico}

\subsubsection{Hibridização in situ}

O RNAm do angiotensinogênio encontrou-se alterado somente nos ratos SHR tratados com nicotina. Houve diminuição da densidade óptica relativa no NTS e PVN. Por outro lado, observou-se aumento da quantidade de RNAm do angiotensinogênio no LC de ratos SHR tratados com nicotina (Tabela 13 e Figura 30).

A análise de variância de 2 vias permitiu concluir que há interação entre o tratamento com nicotina e a linhagem na modulação da expressão do angiotensinogênio no NTS, LC e PVN. O padrão de marcação, assim como sua especificidade podem ser visualizados na figura 31.

Tabela 13. Densidade Óptica Relativa (ROD) da marcação, no filme radiosensível, promovida pela sonda radioativa complementar ao RNAm do angiotensinogênio no núcleo do trato solitário (NTS), locus coeruleus (LC) e núcleo paraventricular hipotalâmico (PVN) de ratos espontaneamente hipertensos (SHR) e Wistar Kyoto (WKY) submetidos a tratamento crônico com nicotina ou placebo.

\begin{tabular}{ccccc}
\hline & & NTS $^{1}$ & LC $^{1}$ & PVN $^{1}$ \\
\hline \multirow{4}{*}{ SHR } & Placebo & $0,5006 \pm 0,01842$ & $0,4554 \pm 0,01369$ & $0,4655 \pm 0,01312$ \\
& Nicotina & $0,4496 \pm 0,009102 *$ & $0,5072 \pm 0,01447 *$ & $0,3760 \pm 0,008426^{*}$ \\
\hline \multirow{2}{*}{ WKY } & Placebo & $0,4849 \pm 0,005484$ & $0,4768 \pm 0,01256$ & $0,4119 \pm 0,01749$ \\
& Nicotina & $0,4805 \pm 0,01777$ & $0,4749 \pm 0,02353$ & $0,4206 \pm 0,03754$ \\
\hline
\end{tabular}

Os valores são apresentados como média aritmética \pm EPM. ${ }^{*} p<0,05$ comparados com 0 placebo da mesma linhagem, segundo a análise de variância de 2 vias (2-way ANOV A). $1=$ a expressão do $\mathrm{RN} A m$ do angiotensinogênio sofre influência da interação entre linhagem e tratamento, segundo a análise de variância de 2 vias. $n=6$. 
NTS AOGEN ${ }^{1}$

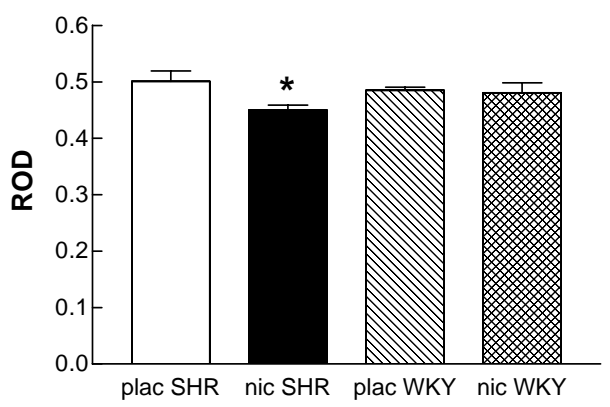

\section{LC AOGEN ${ }^{1}$}

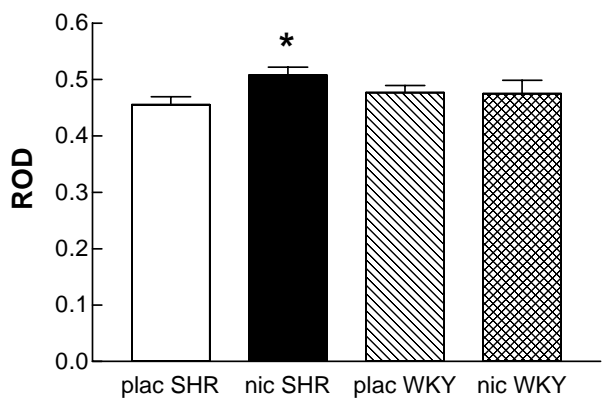

PVN AOGEN $^{1}$

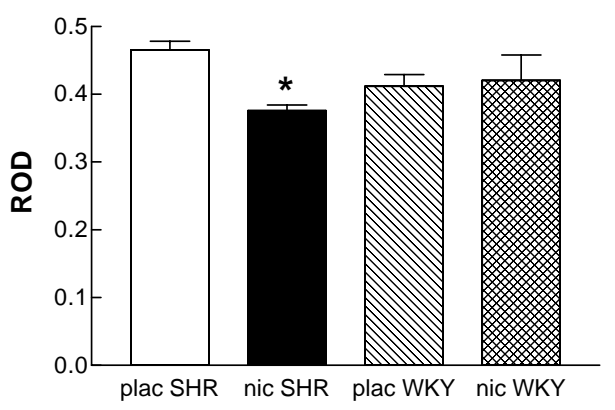

FIGURA 30. Densidade Óptica Relativa (ROD) da marcação, no filme radiosensível, promovida pela sonda radioativa complementar ao RNAm do angiotensinogênio no núcleo do trato solitário (NTS), locus coeruleus (LC) e núcleo paraventricular hipotalâmico (PVN) de ratos espontaneamente hipertensos (SHR) e Wistar Kyoto (WKY) submetidos a tratamento crônico com nicotina (nic) ou placebo (plac). Os valores são apresentados como média aritmética $\pm E P M .{ }^{*} p<0,05$ comparados com o placebo da mesma linhagem, segundo a análise de variância de 2 vias (2-way $A N O V A)$. 1=a expressão do $\mathrm{RN} A m$ do angiotensinogênio sofre influência da interação entre linbagem e tratamento, segundo a análise de variancia de 2 vias. $n=6$ 

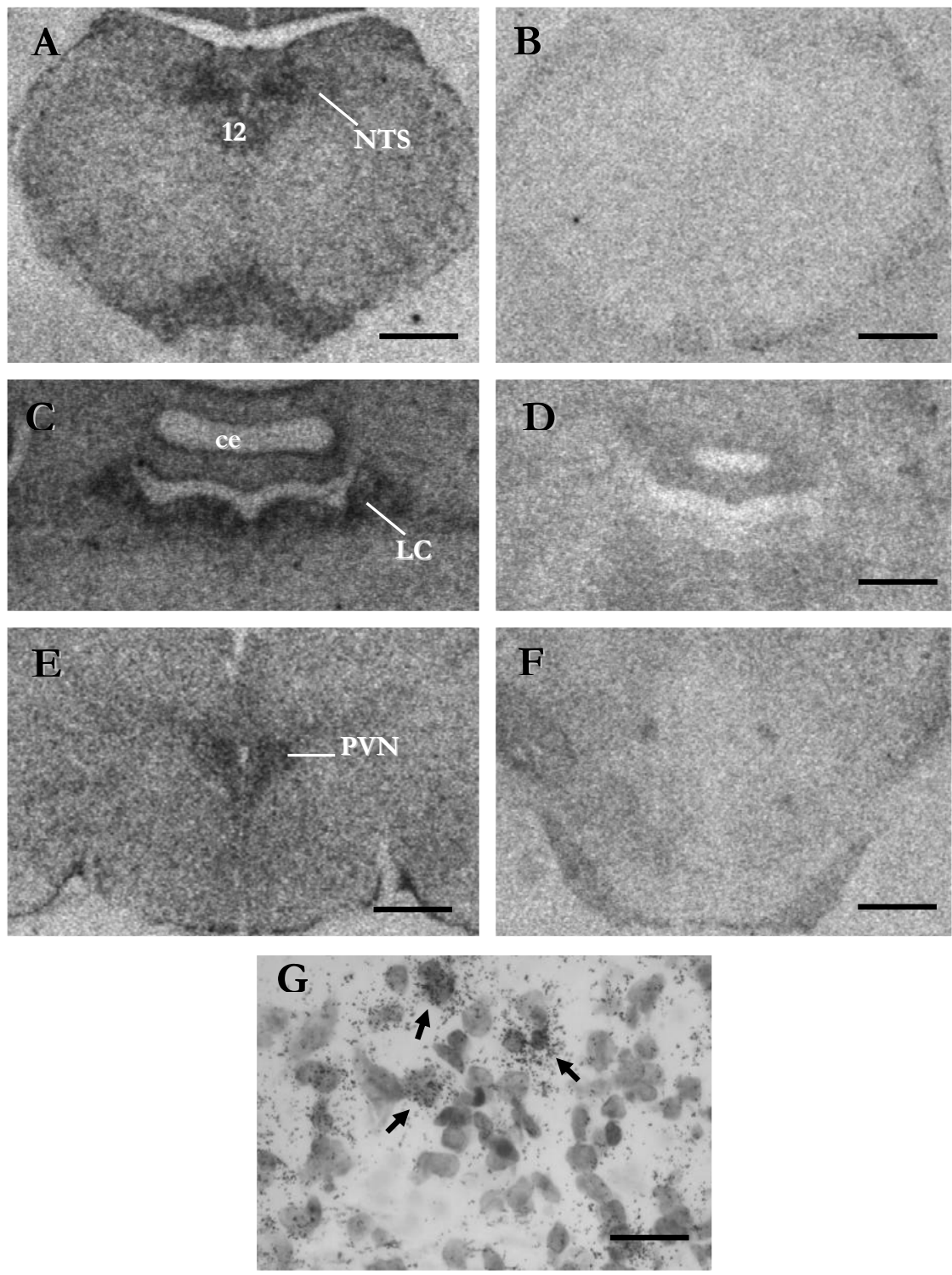

FIGURA 31. Imagens representativas do filme radioautográfico mostrando o padrão de marcação do RNAm do angiotensinogênio por sonda radioativa no núcleo do trato solitário (NTS) (A), locus coeruleus $(\mathrm{LC})(\mathbf{C})$ e núcleo paraventricular do hipotálamo (PVN) (E). Em $\mathbf{B}, \mathbf{D}$ e $\mathbf{F}$ tem-se a ausência de marcação específica devido ao deslocamento da sonda radioativa por sonda não marcada. Em $\mathbf{G}$ temse um exemplo da localização celular da marcação radioativa no PVN, onde as setas indicam regiões com grande densidade de grânulos coincidindo com perfis celulares. Barra de escala $=1 \mathrm{~mm}$ ou $50 \mu \mathrm{m}(\mathbf{G})$. Abreviaturas: $12=$ núcleo hipoglosso, $\mathrm{ce}=$ cerebelo, opt $=$ trato óptico. 


\subsubsection{Análise da Ligação}

Houve diminuição da ligação dos receptores angiotensinérgicos, promovida pelo tratamento com nicotina, no NTS e PVN de ratos SHR. Nos ratos normotensos (WKY), a nicotina induziu aumento na ligação desses receptores no PVN não sendo possível observar alteração no NTS dos ratos WKY (Tabela 14 e Figura 32). Foi observado ainda que, em condições basais, a ligação dos receptores de angiotensina II encontra-se aumentada em ratos SHR.

A figura 33 ilustra a marcação nos núcleos analisados assim como a marcação inespecífica promovida pelo deslocamento do ligante radioativo pelo ligante não marcado em excesso.

Tabela 14. Ligação da $\left[{ }^{125}\right]$ Ang II (fmol.mg proteína ${ }^{-1}$ ) aos seus receptores no núcleo do trato solitário (NTS) e núcleo paraventricular hipotalâmico (PVN) de ratos espontaneamente hipertensos (SHR) e Wistar Kyoto (WKY) submetidos a tratamento crônico com nicotina ou placebo.

\begin{tabular}{cccc}
\hline & & NTS $^{1}$ & PVN $^{2}$ \\
\hline \multirow{2}{*}{ SHR } & Placebo & $5,774 \pm 0,4088$ & $2,805 \pm 0,0907$ \\
& Nicotina & $4,618 \pm 0,3188^{*}$ & $2,515 \pm 0,0604^{*}$ \\
\hline \multirow{2}{*}{ WKY } & Placebo & $4,195 \pm 0,4551^{\#}$ & $2,188 \pm 0,0510^{\#}$ \\
& Nicotina & $5,104 \pm 0,2908$ & $2,472 \pm 0,1045^{*}$
\end{tabular}

Os valores são apresentados como média aritmética $\pm E \overline{P M}{ }^{*} p<0,05$ comparados com 0 placebo da mesma linhagem; ${ }^{\#} p<0,05$ comparados ao SHR com mesma condição de tratamento, segundo a análise de variância de 2 vias (2-way ANOV A). 1=há interação entre a linhagem e o tratamento com nicotina para o valor da ligação; $2=$ a linhagem influencia a ligação e há interação entre linhagem e tratamento para o valor da ligação, segundo a análise de variância de 2 vias. $n=6$. 

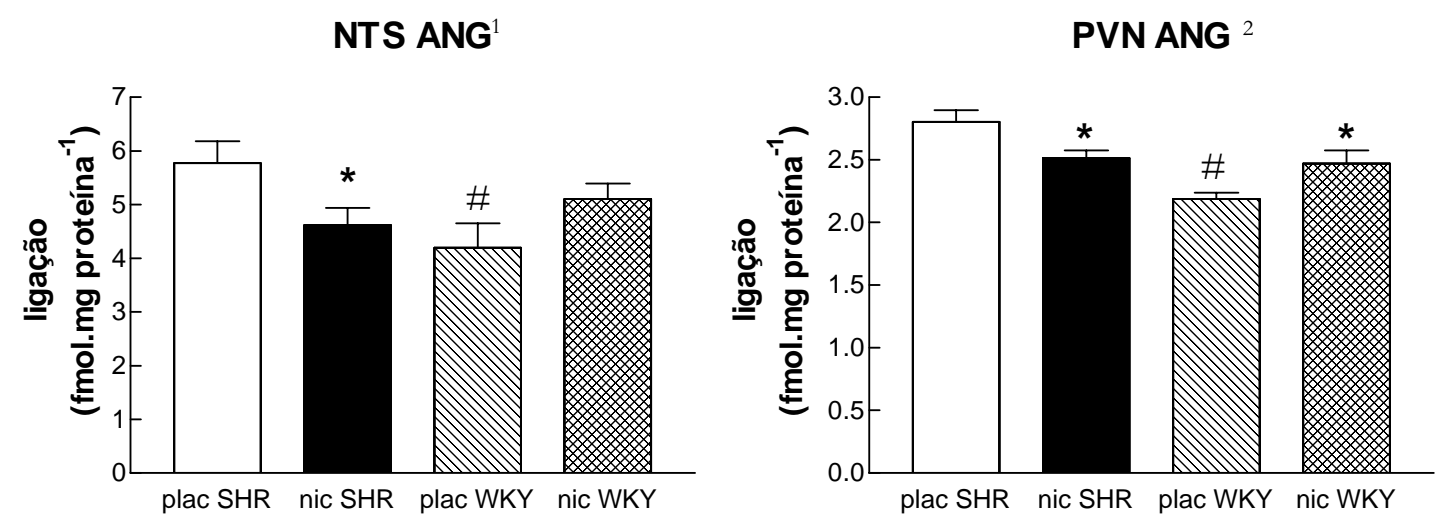

FIGURA 32. Ligação da $\left[{ }^{125} \Gamma\right]$ Ang II (fmol.mg proteína ${ }^{-1}$ ) aos seus receptores no núcleo do trato solitário (NTS) e núcleo paraventricular hipotalâmico (PVN) de ratos espontaneamente hipertensos (SHR) e Wistar Kyoto (WKY) submetidos a tratamento crônico com nicotina (nic) ou placebo (plac). Os valores são apresentados como média aritmética $\pm E P M{ }^{*} p<0,05$ comparados com o placebo da mesma linhagem; ${ }^{\#} p<0,05$ comparados ao SHR com mesma condição de tratamento, segundo a análise de variância de 2 vias (2-way ANOVA). $1=$ há interação entre a linhagem e 0 tratamento com nicotina para o valor da ligação; $2=$ a linhagem influencia a ligação e há interação entre linhagem e tratamento para o valor da ligação, segundo a análise de variância de 2 vias. $n=6$. 

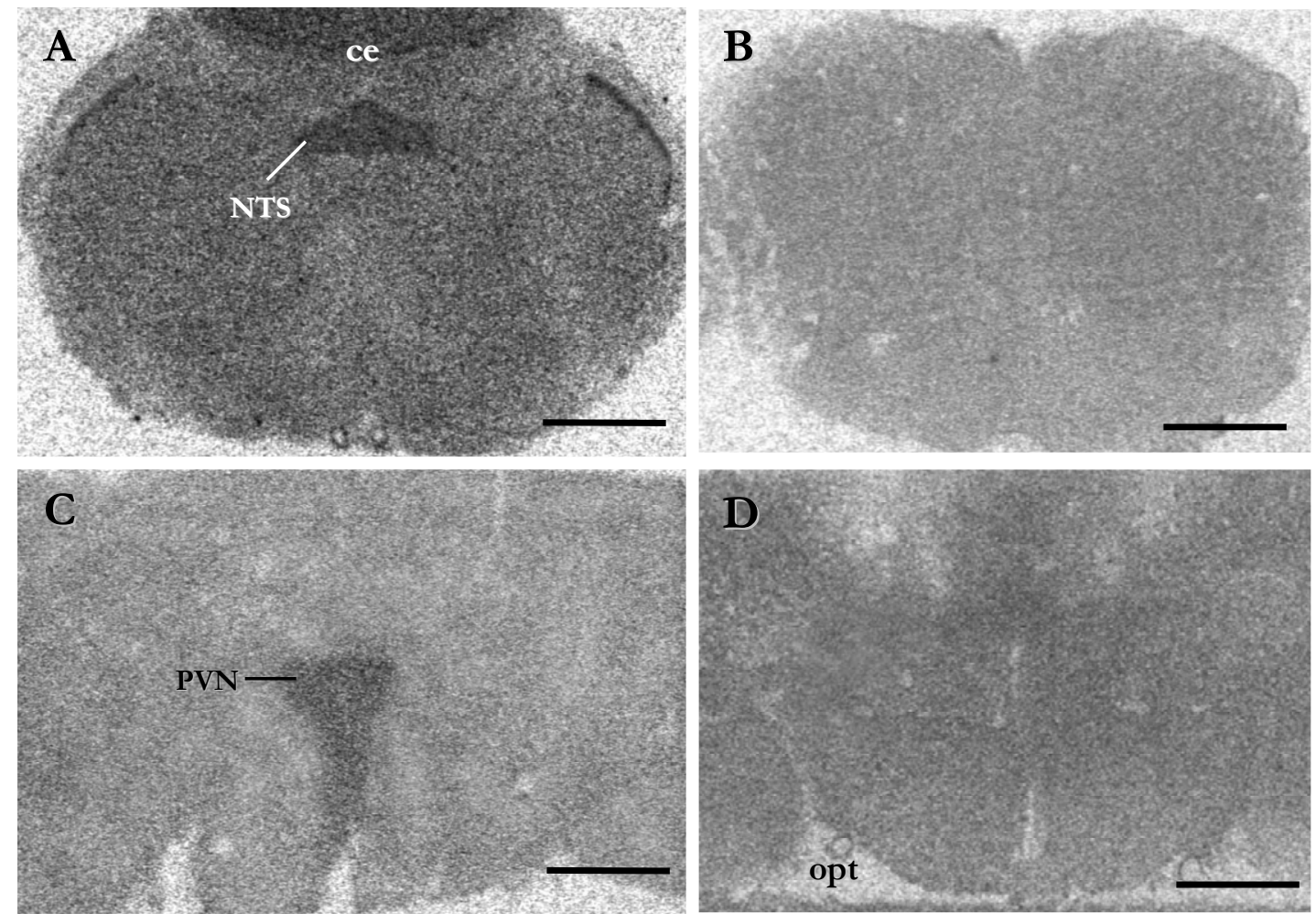

FIGURA 33. Imagens representativas do filme radioautográfico mostrando o padrão de marcação dos receptores da angiotensina II pelo ligante $\left[{ }^{125} \mathrm{I}\right] \mathrm{Sar}^{1}, \mathrm{Il}^{8}$ AngII no núcleo do trato solitário (NTS) (A) e núcleo paraventricular do hipotálamo (PVN) (C). Em B e $\mathbf{D}$ tem-se a ausência de marcação específica devido ao deslocamento do ligante radioativo por angiotensina II fria. Barra de escala $=1 \mathrm{~mm}$. Abreviaturas: $\mathrm{ce}=$ cerebelo opt $=$ trato óptico 


\subsection{Sistema Colinérgico}

\subsubsection{Imunohistoquímica}

Após o tratamento crônico com nicotina, a densidade da imunorreatividade à ChAT encontrou-se aumentada no NTS dos ratos SHR ao passo que observou-se uma tendência à diminuição neste núcleo dos ratos WKY (Tabela 15 e Figura 34).

Em condições basais, há maior intensidade da imunorreatividade à ChAT no NTS de ratos hipertensos que em WKY. Observou-se também que o tratamento crônico com nicotina provocou aumento da área imunorreativa à ChAT no núcleo motor dorsal do nervo vago de WKY se comparado com SHR. Além disso, a análise de variância de duas vias mostrou que a linhagem, o tratamento e a interação entre estes parâmetros influenciam a imunorreatividade à ChAT (Tabela 15 e Figura 34).

Na figura 35, tem-se o padrão de marcação imunohistoquímica nas áreas estudadas. 
Tabela 15. spMGV (unidades arbitrárias) e área (em micrômetros quadrados) ocupada pela imunorreatividade à Colina acetiltransferase (ChAT) no núcleo do trato solitário (NTS), núcleo ambíguo (NA) e núcleo motor dorsal do vago (X) de ratos espontaneamente hipertensos (SHR) e Wistar Kyoto (WKY) submetidos a tratamento crônico com nicotina ou placebo.

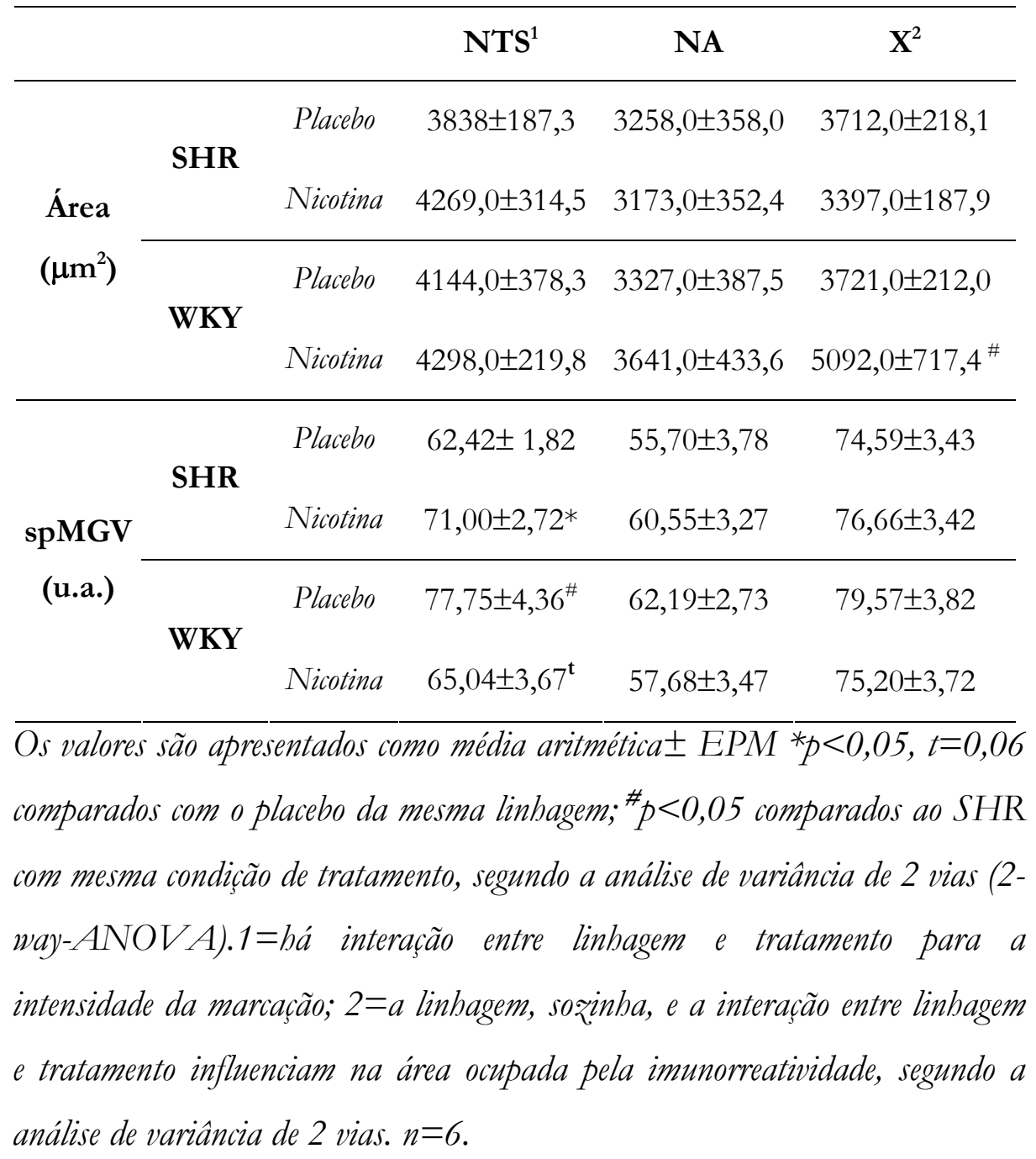


NTS CHAT AREA

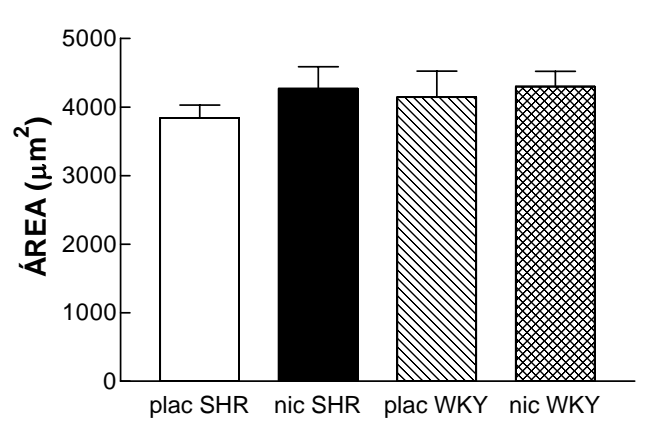

Amb CHAT AREA

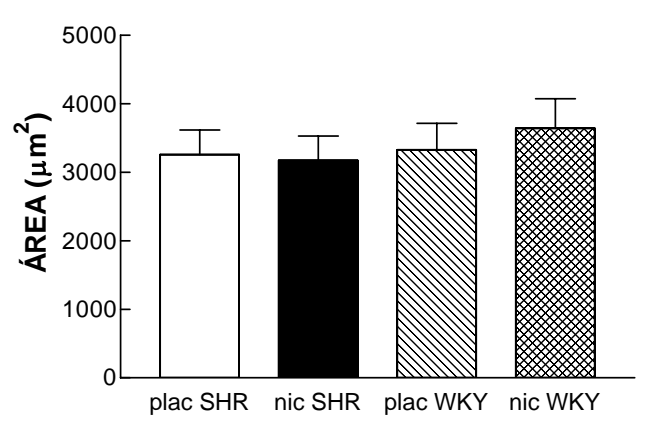

Vago CHAT AREA ${ }^{2}$

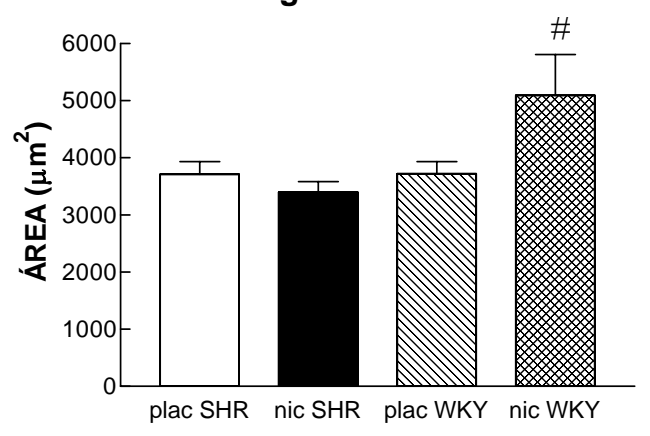

NTS CHAT SPMGV ${ }^{1}$

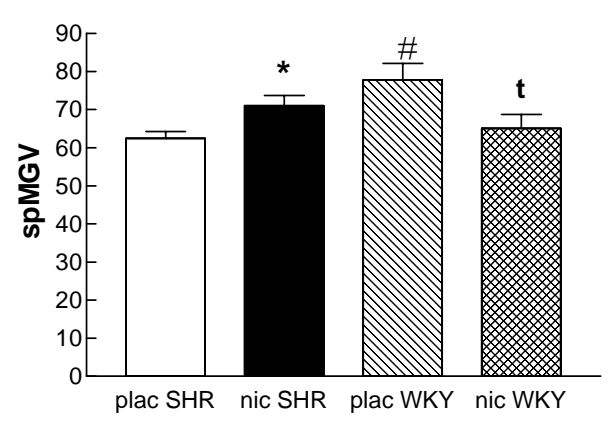

Amb CHAT spMGV

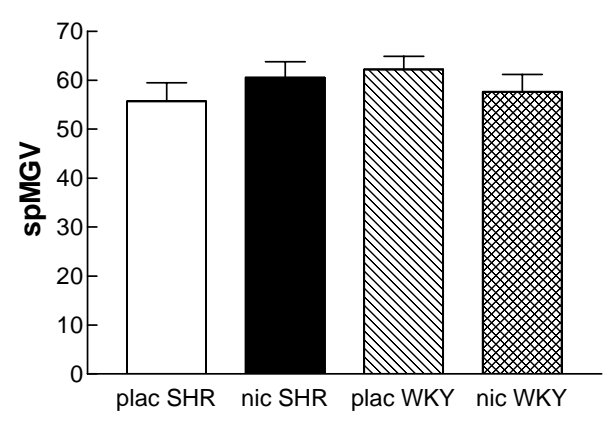

Vago CHAT spMGV

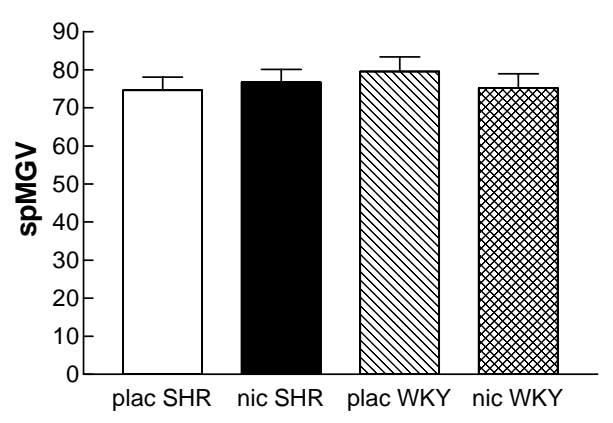

FIGURA 34. spMGV (unidades arbitrárias) e área ocupada pela imunorreatividade à colina acetiltransferase (ChAT) no núcleo do trato solitário (NTS), núcleo ambíguo (Amb) e núcleo motor dorsal do vago de ratos espontaneamente hipertensos (SHR) e Wistar Kyoto (WKY) submetidos a tratamento crônico com nicotina (nic) ou placebo (plac). Os valores são apresentados como média aritmética $\pm E P M{ }^{*} p<0,05, t=0,06$ comparados com o placebo da mesma linhagem, ${ }^{\#} p<0,05$ comparados ao SHR com mesma condição de tratamento, segundo a análise de variância de 2 vias (2-way-ANOVA).1=há interação entre linhagem $e$ tratamento para a intensidade da marcação; 2=a linhagem, soz̧inha, e a interação entre linhagem e tratamento influenciam na área ocupada pela imunorreatividade, segundo a análise de variância de 2 vias. $n=6$. 


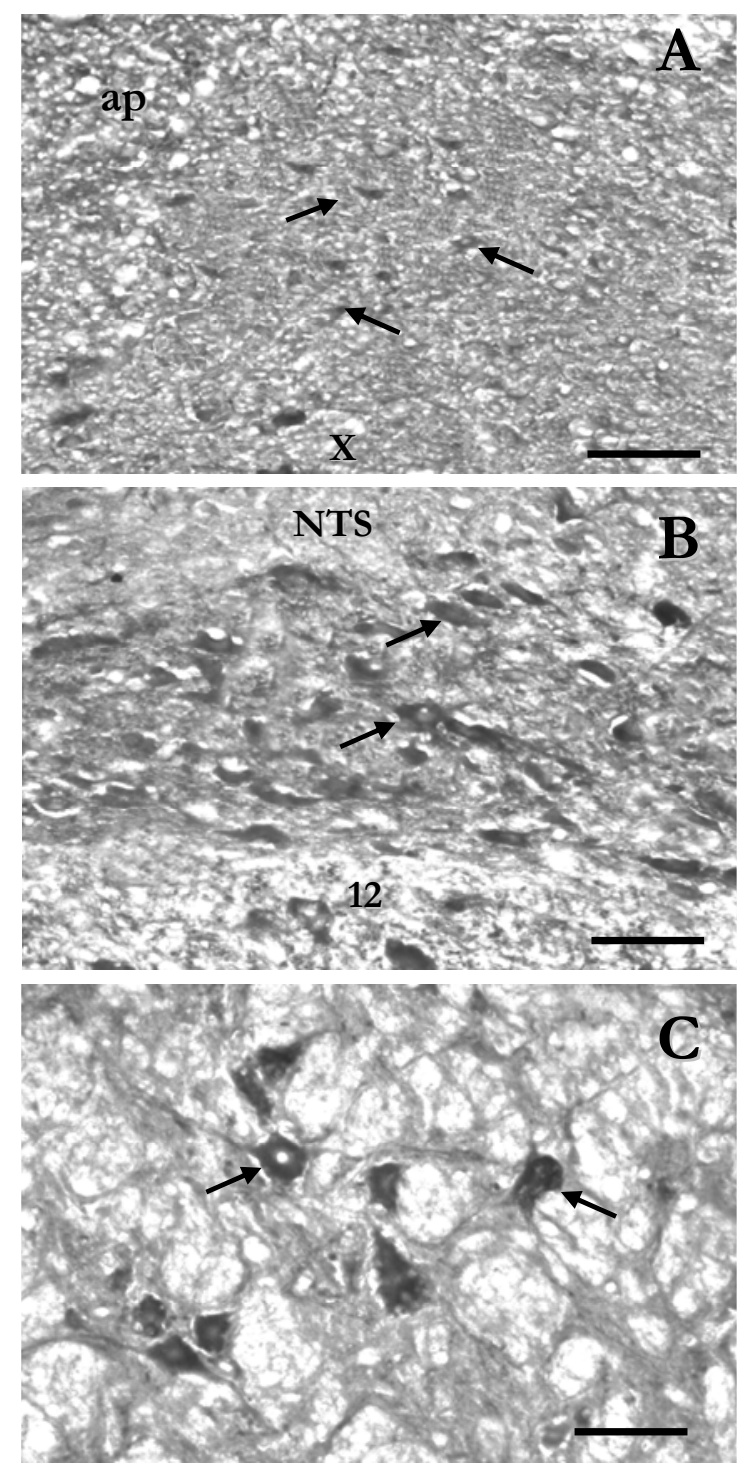

FIGURA 35. Fotomicrografias digitais representativas ilustrando o padrão de marcação da imunorreatividade à colina acetiltransferase (ChAT) no núcleo do trato solitário (NTS) (A), núcleo motor dorsal do vago $(\mathrm{X})(\mathbf{B})$ e núcleo ambíguo (C). Abreviaturas: ap=área postrema. As setas indicam alguns dos perfis celulares considerados na quantificação. Barra de escala $=50 \mu \mathrm{m}$. 


\subsubsection{Hibridização in situ}

A análise dos receptores nicotínicos deu-se através da marcação do RNAm das subunidades alfa3, beta4 e alfa7 já que estes são os tipos de receptores nicotínicos mais abundantes no NTS e com reconhecida função no controle cardiovascular.

O tratamento com nicotina promoveu diminuição na densidade óptica da marcação promovida pela sonda radioativa complementar ao RNAm da subunidade alfa 3 de receptores nicotínicos no NTS de ratos SHR e no LC de WKY (Tabela 16, Figura 36). Além disso, a quantidade de RNAm da subunidade alfa3 do receptor nicotínico encontra-se diminuída no NTS de ratos SHR comparados a WKY após tratamento com nicotina (Tabela 16, Figura 36). A análise de variância de duas vias permitiu ainda verificar a influência do tratamento e da linhagem, separadamente, sobre a expressão do RNAm desta subunidade.

A figura 37 ilustra o padrão de marcação pela sonda complementar ao RNAm da subunidade alfa 3 do receptor nicotínico no NTS e LC. 
NTS nic alfa $3^{1}$

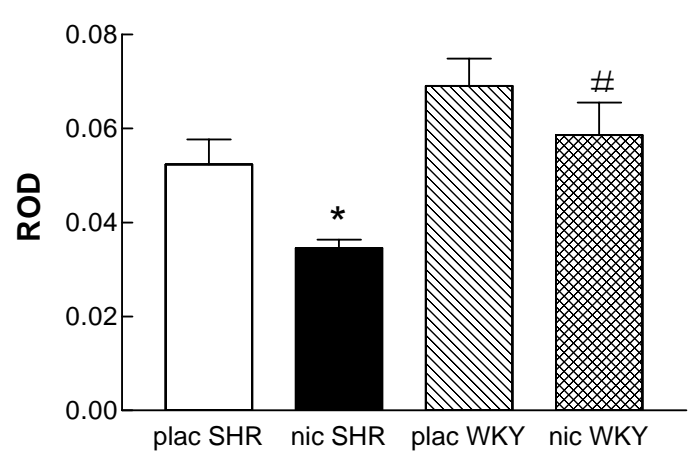

LC nic alfa 3

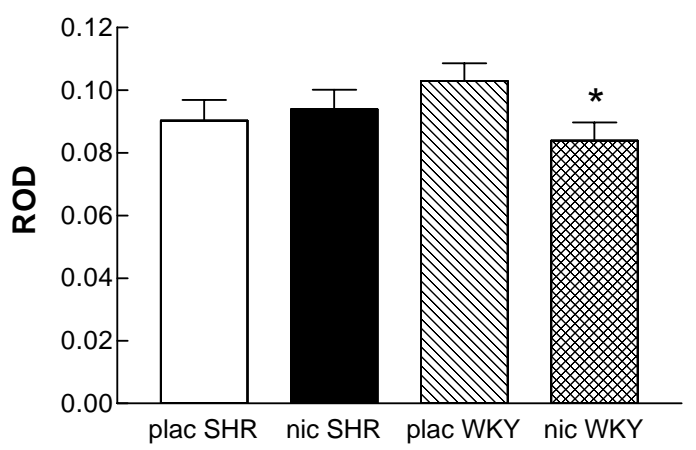

FIGURA 36. Histogramas ilustrando a densidade óptica relativa (ROD) da marcação, no filme radiosensível, promovida pela sonda radioativa complementar ao RNAm da subunidade alfa3 do receptor nicotínico no núcleo do trato solitário (NTS) e locus coeruleus (LC) de ratos espontaneamente hipertensos (SHR) e Wistar Kyoto (WKY) submetidos a tratamento crônico com nicotina (nic) ou placebo (pla). Os valores são apresentados como média aritmética \pm EPM. ${ }^{*} p<0,05$ comparados com o placebo da mesma linhagem; ${ }^{\#} p<0,05$ comparados ao SHR com mesma condição de tratamento, segundo a análise de variância de 2 vias $(2-w a y-A N O V A) .1=a$ linhagem e o tratamento, separadamente, influenciam na expressão do $\mathrm{RNAm}$, segundo a análise de variância de 2 vias. $n=6$. 

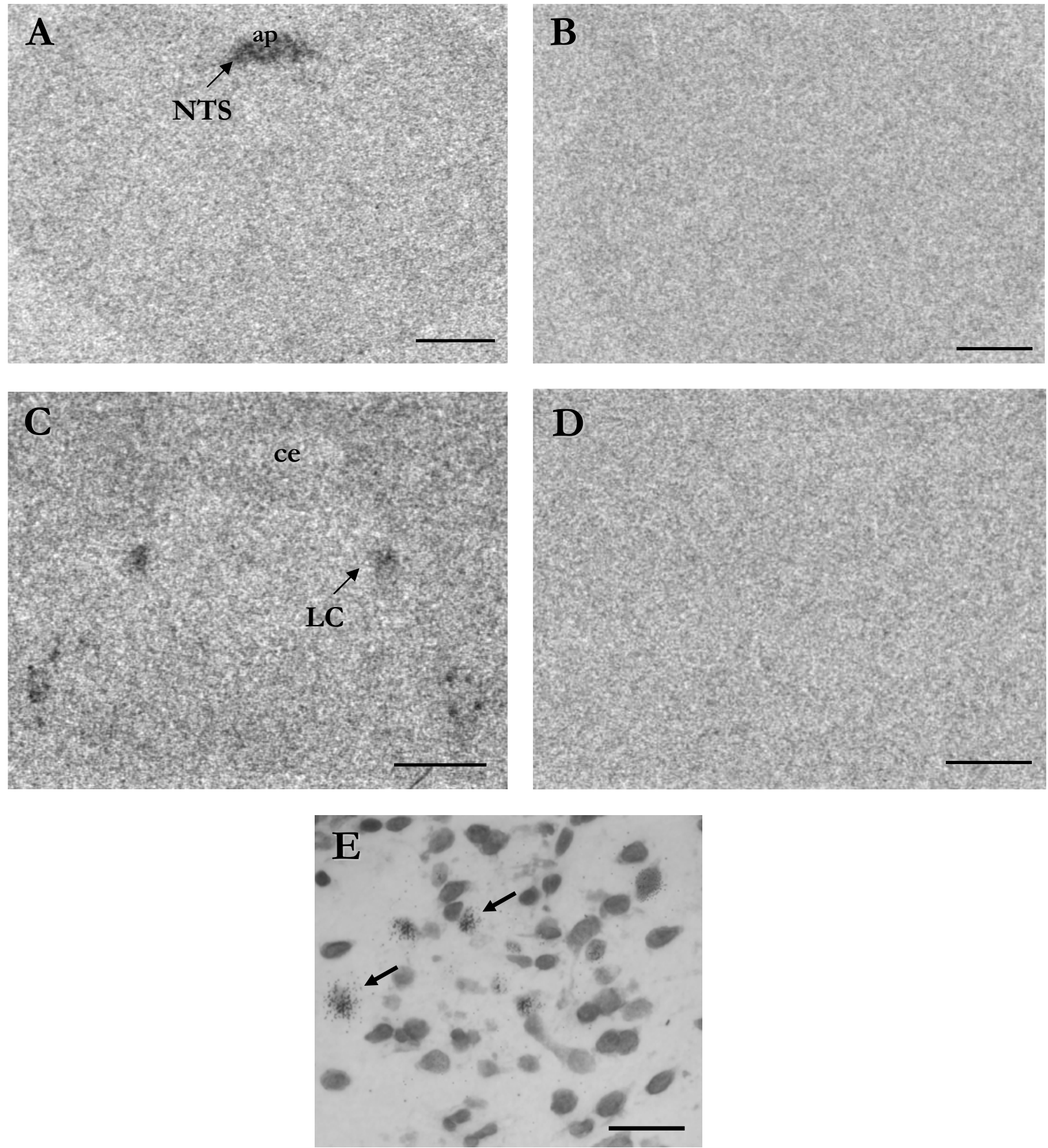

FIGURA 37. Imagens representativas ilustrando a marcação, no filme radiosensível, promovida pela sonda radioativa complementar ao RNAm da subunidade alfa3 do receptor nicotínico no núcleo do trato solitário (NTS) (A) e no locus coeruleus (LC) (B) assim como o controle de especificidade da sonda deslocada com excesso de sonda não marcada $(\mathbf{C}$ e $\mathbf{D})$. Em $\mathbf{E}$ tem-se um exemplo da localização celular da marcação radioativa no LC, onde as setas indicam regiões com grande densidade de grânulos coincidindo com perfis celulares. Barra de escala $=1 \mathrm{~mm}$ ou $50 \mu \mathrm{m}$ (E)Abreviaturas: ce $=$ cerebelo, ap=área postrema. 
O RNAm da subunidade beta4 do receptor nicotínico não sofreu alteração com o tratamento com nicotina (Tabela 17, figura 38). No entanto, a expressão deste RNAm sofre influência da linhagem de ratos. Na figura 39 pode-se observar o padrão de marcação deste RNAm no NTS e LC.

Tabela 17. Densidade Óptica Relativa (ROD) da marcação, no filme radiosensível, promovida pela sonda radioativa complementar ao RNAm da subunidade beta4 do receptor nicotínico no núcleo do trato solitário (NTS) e locus coeruleus (LC) de ratos espontaneamente hipertensos (SHR) e Wistar Kyoto (WKY) submetidos a tratamento crônico com nicotina ou placebo.

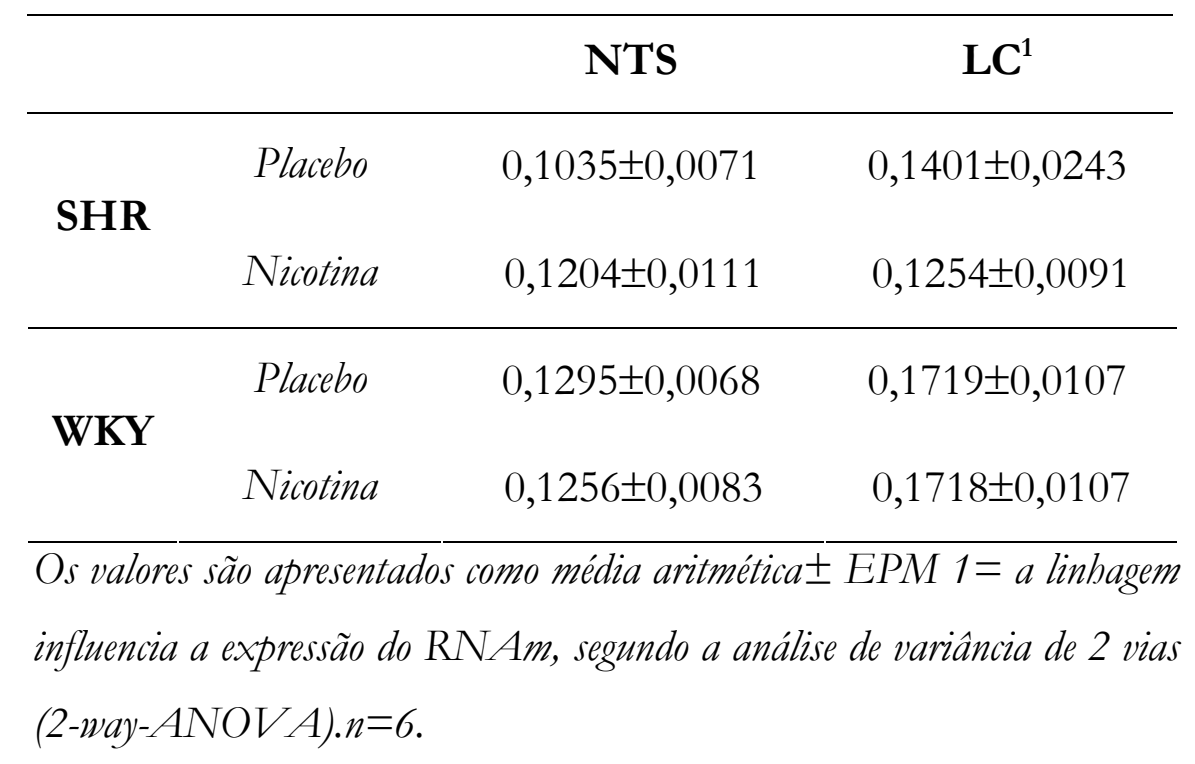


NTS nic beta 4

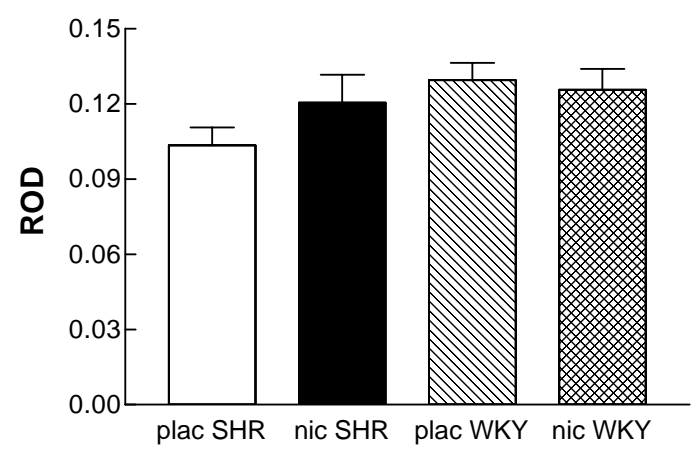

LC nic beta $4^{1}$

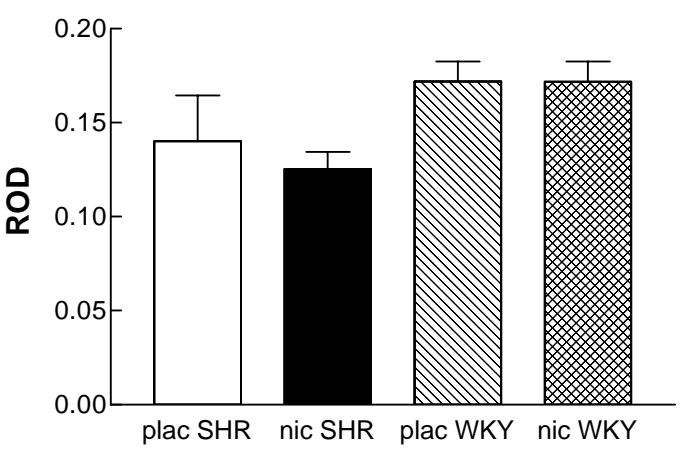

FIGURA 38. Histogramas ilustrando a densidade óptica relativa (ROD) da marcação, no filme radiosensível, promovida pela sonda radioativa complementar ao RNAm da subunidade beta4 do receptor nicotínico no núcleo do trato solitário (NTS) e locus coeruleus (LC) de ratos espontaneamente hipertensos (SHR) e Wistar Kyoto (WKY) submetidos a tratamento crônico com nicotina (nic) ou placebo (pla). Os valores são apresentados como média aritmética \pm EPM 1= a linhagem influencia a expressão do $\mathrm{RN} A m$, segundo a análise de variância de 2 vias (2-way- $A N O V A) \cdot n=6$. 

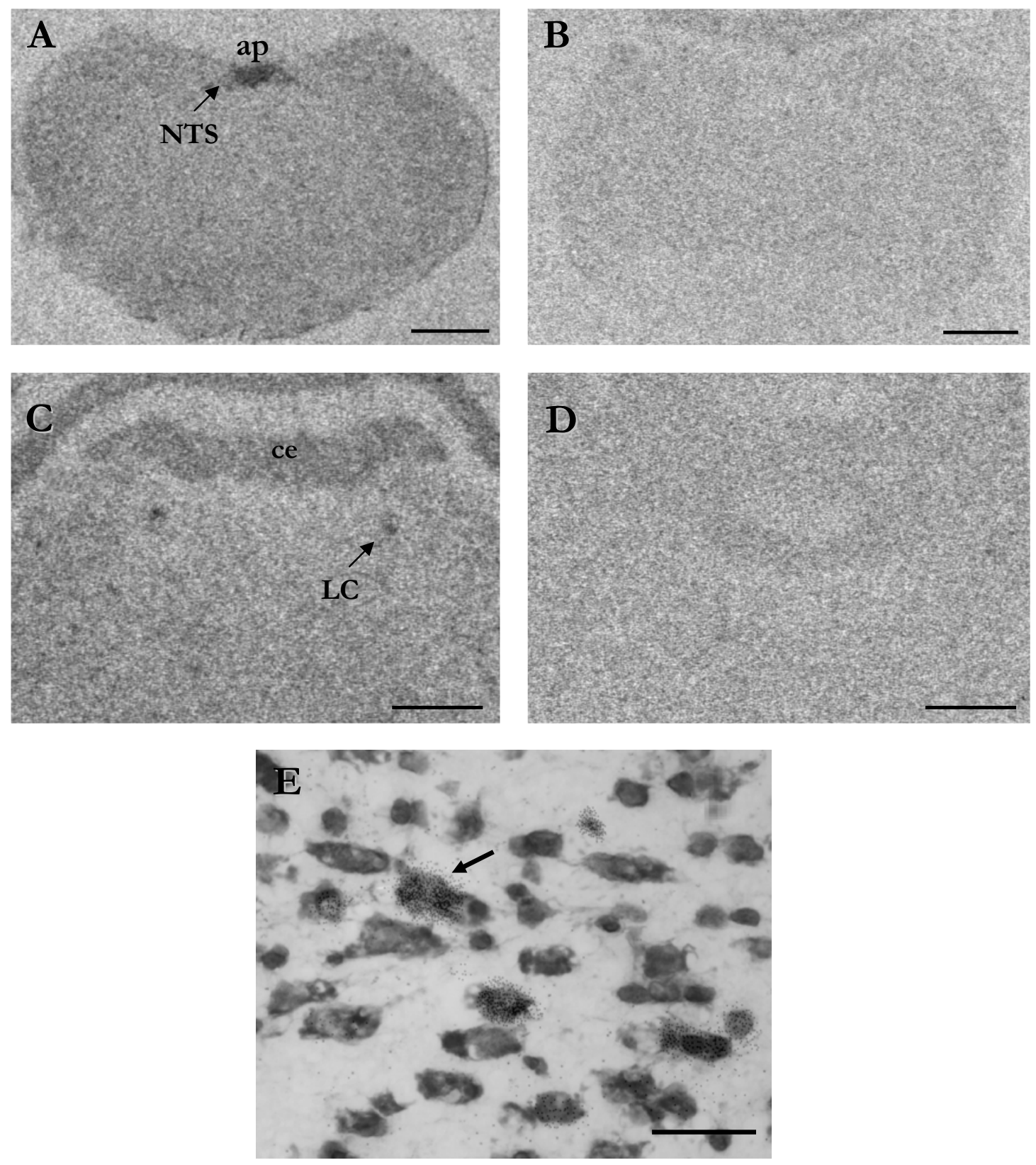

FIGURA 39. Imagens representativas ilustrando a marcação, no filme radiosensível, promovida pela sonda radioativa complementar ao RNAm da subunidade beta4 do receptor nicotínico no núcleo do trato solitário (NTS) (A) e no locus coeruleus (LC) (B) assim como o controle de especificidade da sonda deslocada com excesso de sonda não marcada (C e D). Em E tem-se um exemplo da localização celular da marcação radioativa no LC. Abreviaturas: ce $=$ cerebelo, ap=área postrema. Barra de escala $=1 \mathrm{~mm}$ e $30 \mu \mathrm{m}(\mathrm{E})$. 
Houve diminuição do RNAm da subunidade alfa7 do receptor nicotínico no LC e PVN somente de ratos WKY tratados com nicotina. Os ratos SHR não apresentaram alteração na expressão deste RNAm nos núcleos de estudo (Tabela 18, Figura 40). Segundo a análise de variância de 2 vias, o tratamento com nicotina, assim como a interação entre a nicotina e a linhagem modulam a expressão do RNAm da subunidade alfa7 do receptor nicotínico no LC e PVN (Tabela 18, Figura 40). Na figura 41 observa-se a marcação desta subunidade nos núcleos estudados.

Tabela 18. Densidade Óptica Relativa (ROD) da marcação, no filme radiosensível, promovida pela sonda radioativa complementar ao RNAm da subunidade alfa7 do receptor nicotínico no núcleo do trato solitário (NTS), locus coeruleus (LC) e núcleo paraventricular hipotalâmico (PVN) de ratos espontaneamente hipertensos (SHR) e Wistar Kyoto (WKY) submetidos a tratamento crônico com nicotina ou placebo.

\begin{tabular}{ccccc}
\hline & & NTS & LC $^{1}$ & PVN $^{2}$ \\
\hline \multirow{2}{*}{ SHR } & Placebo & $0,2578 \pm 0,0273$ & $0,3825 \pm 0,0278$ & $0,0687 \pm 0,0120$ \\
& Nicotina & $0,2646 \pm 0,0228$ & $0,3730 \pm 0,0109$ & $0,0732 \pm 0,0060$ \\
\hline \multirow{2}{*}{ WKY } & Placebo & $0,2941 \pm 0,0255$ & $0,4326 \pm 0,0210$ & $0,0825 \pm 0,0139$ \\
& Nicotina & $0,2737 \pm 0,0185$ & $0,3595 \pm 0,0135^{*}$ & $0,0538 \pm 0,0050^{*}$ \\
\hline
\end{tabular}

Os valores são apresentados como média aritmética \pm EPM. ${ }^{*} p<0,05$ comparados com o placebo da mesma linhagem, segundo a análise de variância de 2 vias (2-wayANOVA) . 1= o tratamento, soẓinho, e a interação entre tratamento e linhagem influenciam a expressão do RNAm; 2= há uma tendência $(p=0,07)$ em haver interação entre linhagem e tratamento para a expressão do $\mathrm{RN} A m$, segundo a análise de variância de 2 vias. $n=6$. 
NTS alfa 7

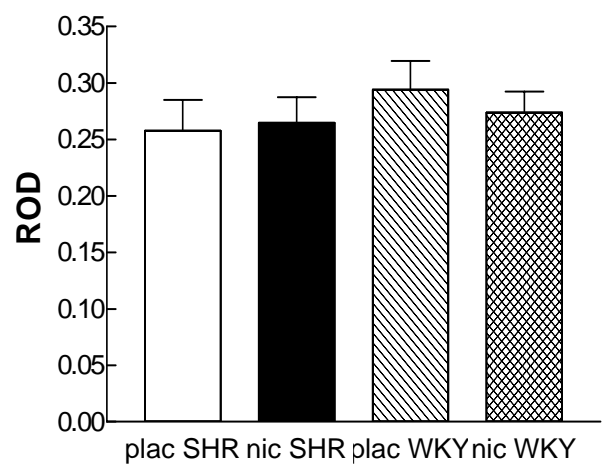

LC alfa $7^{1}$

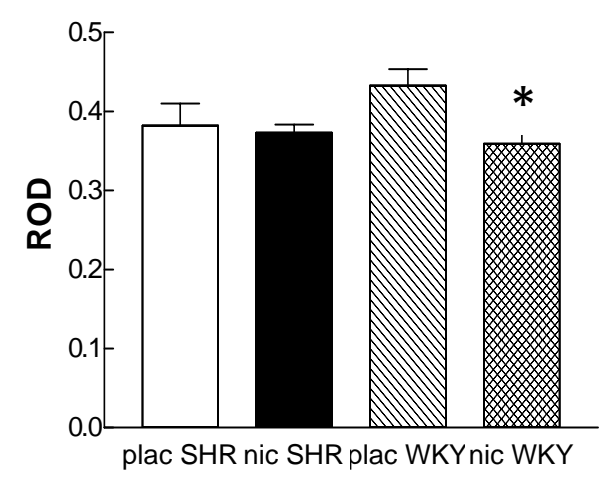

PVNalfa $7^{2}$

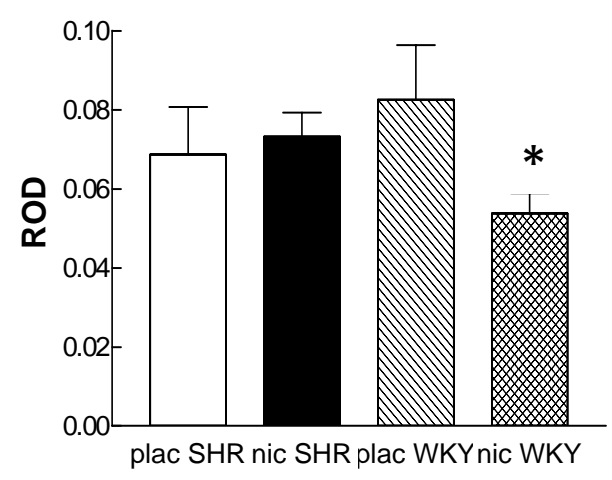

FIGURA 40. Histogramas ilustrando a densidade óptica relativa (ROD) da marcação, no filme radiosensível, promovida pela sonda radioativa complementar ao RNAm da subunidade alfa7 do receptor nicotínico no núcleo do trato solitário (NTS) e locus coeruleus (LC) de ratos espontaneamente hipertensos (SHR) e Wistar Kyoto (WKY) submetidos a tratamento crônico com nicotina (nic) ou placebo (pla). Os valores são apresentados como média aritmética $\pm E P M .{ }^{*} p<0,05$ comparados com o placebo da mesma linhagem, segundo a análise de variancia de 2 vias (2-way-ANOV A). 1= o tratamento, sozinho, e a interação entre tratamento e linhagem influenciam a expressão do RNAm;2= há uma tendência $(p=0.07)$ em haver interaşão entre linhagem e tratamento para a expressão do RNAm, segundo a análise de variância de 2 vias. $n=6$. 

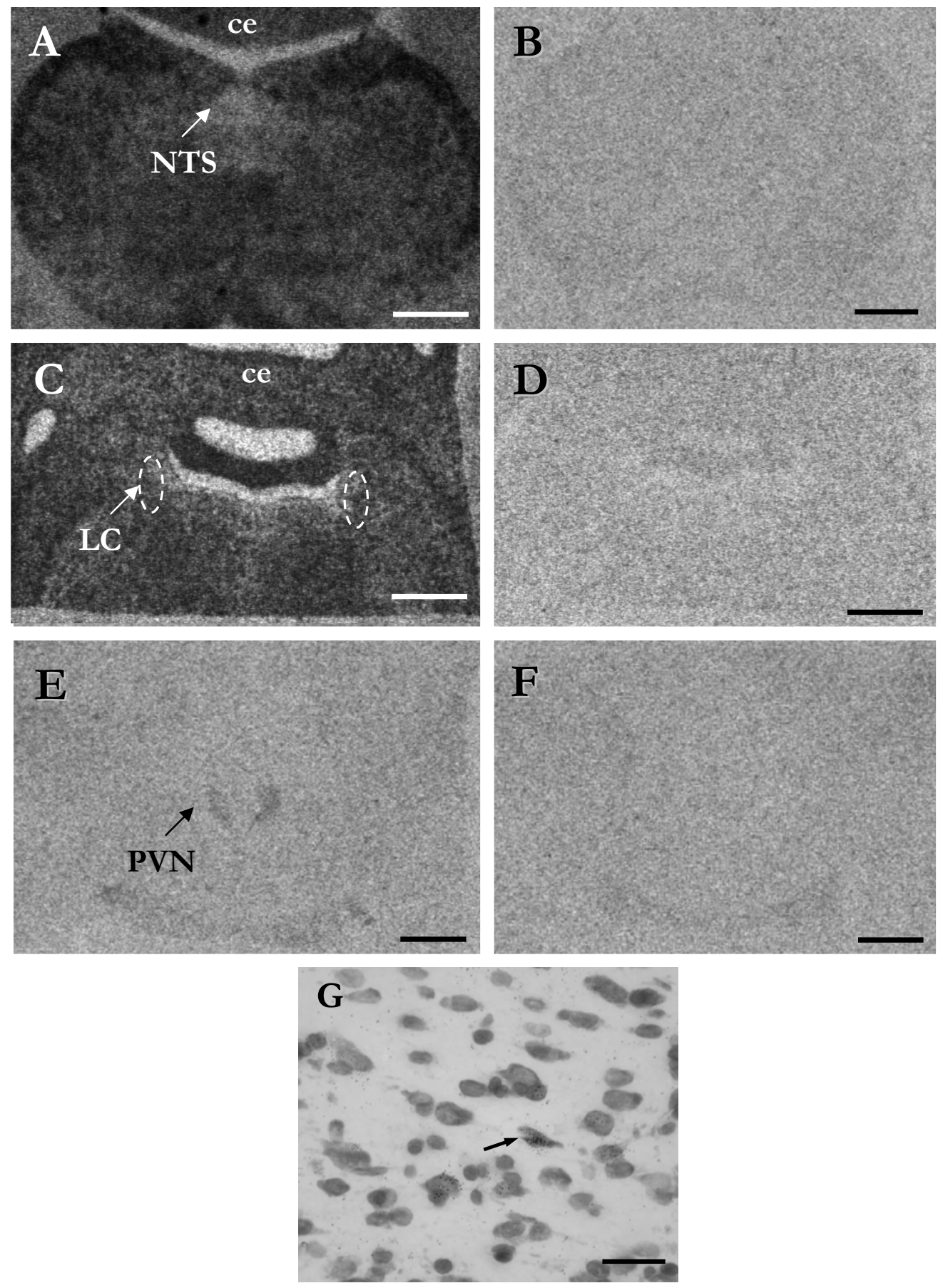

FIGURA 41. Imagens representativas ilustrando a marcação, no filme radiosensível, promovida pela sonda radioativa complementar ao RNAm da subunidade alfa7 do receptor nicotínico no núcleo do trato solitário (NTS) (A), locus coeruleus (LC) (C) e núcleo paraventricular hipotalâmico (PVN) (E) assim como o controle de especificidade da sonda deslocada com excesso de sonda não marcada (B, D e F). Em $\mathbf{G}$ observa-se a localização celular da marcação no PVN. Abreviatura: ce $=$ cerebelo. Barra de escala $=1 \mathrm{~mm}$ e $50 \mu \mathrm{m}(\mathrm{G})$. 
Ratos SHR tratados com nicotina apresentaram aumento da expressão do RNAm da ChAT no núcleo motor dorsal do vago. Já os ratos WKY não apresentaram alteração dos níveis de RNAm da CHAT nesta região encefálica. No núcleo ambíguo, não houve alteração neste RNAm promovida pelo tratamento com nicotina em ambas as linhagens de rato (Tabela 19, Figura 42). A expressão do RNAm da ChAT foi maior no vago de ratos SHR comparados a WKY após tratamento com nicotina. Segundo a análise de variância de duas vias, a expressão deste RNAm no núcleo motor dorsal do vago é influenciado pela linhagem, tratamento e interação entre estes dois.

A figura 43 exemplifica o padrão de marcação da ChAT nos núcleos motor dorsal do vago e ambíguo.

TABELA 19. Densidade Óptica Relativa (ROD) da marcação, no filme radiosensível, promovida pela sonda radioativa complementar ao RNAm da colina acetiltransferase (ChAT) no núcleo motor dorsal do vago (vago) e no núcleo ambíguo (amb) de ratos espontaneamente hipertensos (SHR) e Wistar Kyoto (WKY) submetidos a tratamento crônico com nicotina ou placebo.

\begin{tabular}{|c|c|c|c|}
\hline & & VAGO $^{1}$ & AMB \\
\hline \multirow{2}{*}{ SHR } & Placebo & $0,0922 \pm 0,0136$ & $0,0841 \pm 0,0078$ \\
\hline & Nicotina & $0,1425 \pm 0,0101 *$ & $0,0761 \pm$ \\
\hline \multirow{2}{*}{ WKY } & Placebo & $0,0884 \pm 0,0053$ & $0,0939 \pm 0,0116$ \\
\hline & Nicotina & $0,0915 \pm 0,0065^{\#}$ & $0,0819 \pm 0,0089$ \\
\hline \multicolumn{4}{|c|}{$\begin{array}{l}\text { Os valores são apresentados como média aritmética } \pm \\
\text { EPM. }{ }^{*}<0,05 \text { comparado com SHR placebo; }{ }^{\#} p<0,05 \\
\text { comparado ao SHR tratado com nicotina, segundo a análise de } \\
\text { variância de } 2 \text { vias (2-way-ANOVA). } 1=\text { há influência do do } \\
\text { tratamento, da linhagem e bá interação entre estes na expressáo } \\
\text { do RNAm; segundo a análise de variância de } 2 \text { vias. } n=6 \text {. }\end{array}$} \\
\hline
\end{tabular}


VAGO $^{\text {CHAT }^{1}}$

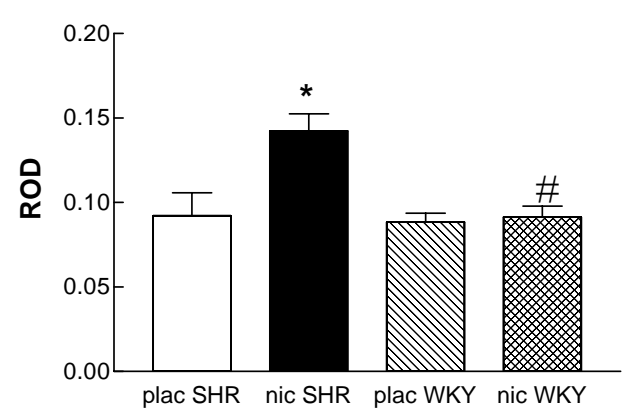

AMB CHAT

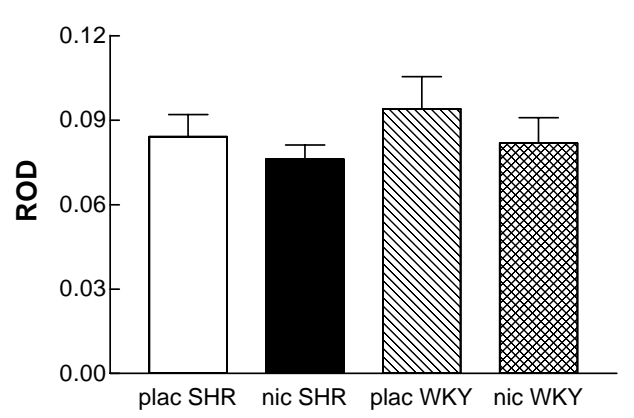

FIGURA 42. Histogramas ilustrando a densidade óptica relativa (ROD) da marcação, no filme radiosensível, promovida pela sonda radioativa complementar ao RNAm da colina acetiltransferase (ChAT) no núcleo motor dorsal do vago (vago) e núcleo ambíguo (amb) de ratos espontaneamente hipertensos (SHR) e Wistar Kyoto (WKY) submetidos a tratamento crônico com nicotina (nic) ou placebo (pla). Os valores são apresentados como média aritmética $\pm E P M .{ }^{*} p<0,05$ comparado com SHR placebo; ${ }^{*} p<0,05$ comparado ao SHR tratado com nicotina, segundo a análise de variancia de 2 vias (2-way-ANOV $A) .1=$ há influência do tratamento, da linhagem e há interaşão entre estes na expressão do RNAm; segundo a análise de variância de 2 vias. $n=6$. 

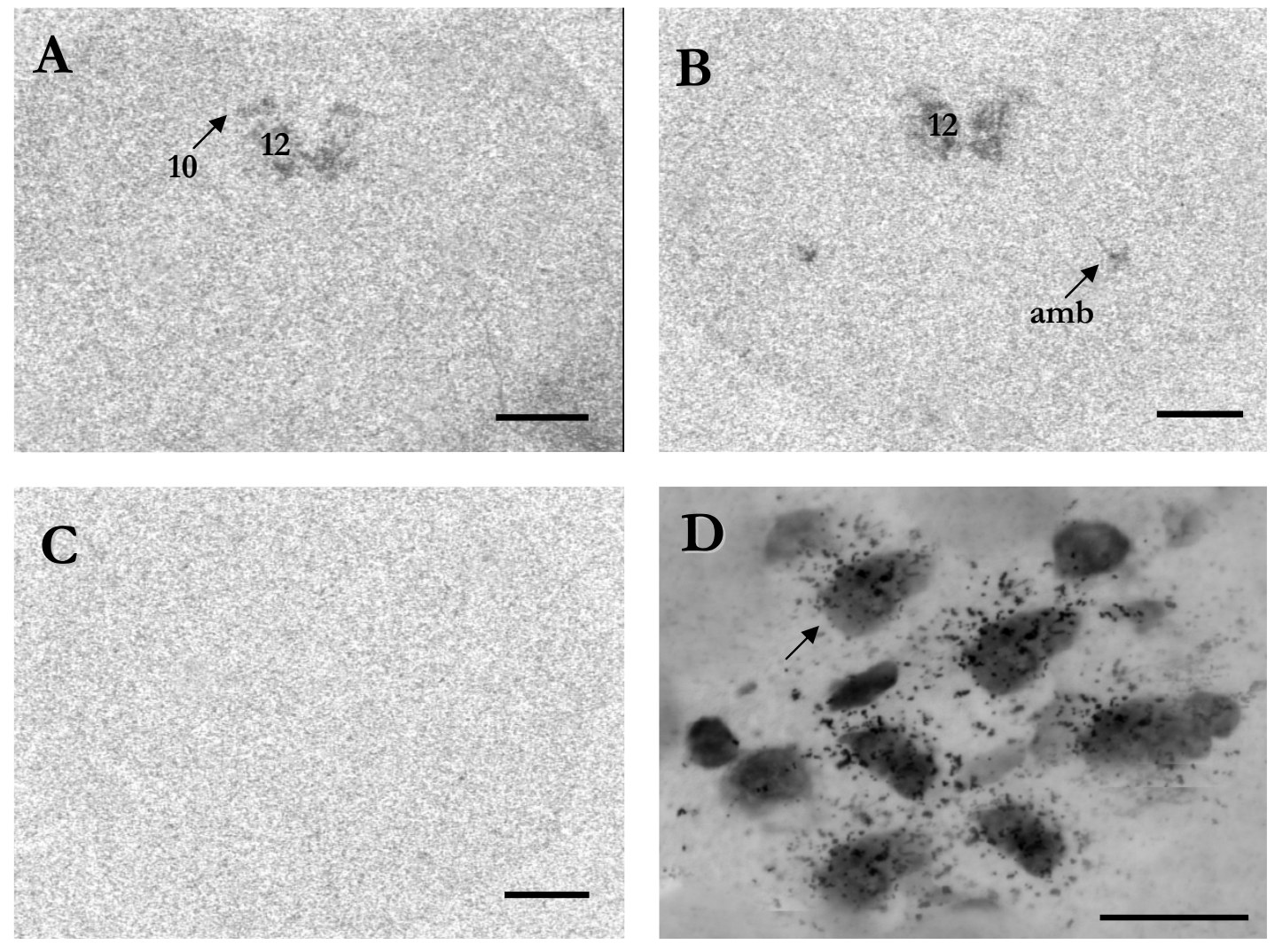

FIGURA 43. Imagens representativas ilustrando a marcação, no filme radiosensível, promovida pela sonda radioativa complementar ao RNAm da colina acetiltransferase (ChAT) no núcleo motor dorsal do vago (10) (A) e no núcleo ambíguo ( $\mathrm{amb}$ ) (B) assim como o controle de especificidade da sonda deslocada com excesso de sonda não marcada (C). Em D observa-se a localização celular da marcação no núcleo ambíguo. Abreviaturas: $12=$ núcleo do nervo hipoglosso. Barra de escala $=1 \mathrm{~mm}$ e $30 \mu \mathrm{m}$ (D). 


\subsection{Sistema Glutamatérgico}

\subsubsection{Imunohistoquímica}

O tratamento crônico com nicotina promoveu diminuição da imunorreatividade do glutamato no NTS e VLM dos ratos SHR, ao contrário dos ratos WKY que apresentaram aumento nesta imunorreatividade no NTS. O LC e PVN dos SHR apresentaram aumento da densidade do glutamato (Tabela 20 e Figura 44).

Foi encontrado que, em situações basais, o NTS e a VLM de ratos SHR apresentam maior imunorreatividade ao glutamato que ratos WKY. No entanto a situação de inverte para o NTS quando da administração crônica de nicotina revelando menor imunorreatividade no SHR que em WKY. O PVN de ratos SHR também apresenta maior imunorreatividade que esta mesma área de normotensos após tratamento crônico com nicotina (Tabela 20 e Figura 44).

A análise de variância de duas vias permitiu observar que a imunorreatividade ao glutamato depende da linhagem, do tratamento com nicotina e é influenciada pela interação ente estes dois parâmetros nos núcleos encefálicos responsáveis pelos controle central da pressão arterial (Tabela 20 e Figura 44).

A figura 45 ilustra o padrão de marcação imunohistoquímica nos núcleos estudados. 
TABELA 20. spMGV (unidades arbitrárias) e área (em micrômetros quadrados) ocupada pela imunorreatividade ao Glutamato no núcleo do trato solitário (NTS), medula oblonga ventrolateral (VLM), locus coeruleus (LC) e núcleo paraventricular hipotalâmico (PVN) de ratos espontaneamente hipertensos (SHR) e Wistar Kyoto (WKY) submetidos a tratamento crônico com nicotina ou placebo.

\begin{tabular}{|c|c|c|c|c|c|c|}
\hline & & & NTS $^{1}$ & $\mathrm{VLM}^{2}$ & $\mathbf{L C}^{3}$ & $\mathbf{P V N}^{4}$ \\
\hline \multirow{5}{*}{$\begin{array}{l}\text { Área } \\
\left(\mu \mathrm{m}^{2}\right)\end{array}$} & \multirow{2}{*}{ SHR } & Placebo & $7748,0 \pm 602,1$ & $4291,0 \pm 177,6$ & $4360,0 \pm 723,6$ & $4866,0 \pm 353,3$ \\
\hline & & Nicotina & $5875,0 \pm 435,9 *$ & $3545,0 \pm 224,3^{*}$ & $4232,0 \pm 628,2$ & $5369,0 \pm 530,0$ \\
\hline & \multirow{3}{*}{ WKY } & Placebo & $5535,0 \pm 228,7^{\#}$ & $3297,0 \pm 235,2^{\#}$ & $3434,0 \pm 389,6$ & $4905,0 \pm 622,1$ \\
\hline & & & & & & \\
\hline & & Nicotina & $7710,0 \pm 713,6^{* \#}$ & $2809,0 \pm 324,1$ & $3105,0 \pm 671,1$ & $5311,0 \pm 623,1$ \\
\hline \multirow{5}{*}{$\begin{array}{c}\text { spMGV } \\
\text { (u.a.) }\end{array}$} & \multirow{2}{*}{ SHR } & Placebo & $88,40 \pm 4,05$ & $47,98 \pm 5,93$ & $80,18 \pm 3,56$ & $88,52 \pm 3,27$ \\
\hline & & Nicotina & $82,98 \pm 2,87$ & $38,42 \pm 3,58$ & $94,33 \pm 3,55^{*}$ & $99,05 \pm 2,25^{*}$ \\
\hline & \multirow{3}{*}{ WKY } & Placebo & $82,22 \pm 2,34$ & $39,76 \pm 5,57$ & $82,25 \pm 1,93$ & $79,97 \pm 4,69$ \\
\hline & & & & & & \\
\hline & & Nicotina & $84,29 \pm 3,972$ & 40,48土7,053 & $90,34 \pm 5,90$ & $86,25 \pm 1,71^{\#}$ \\
\hline
\end{tabular}

Os valores são apresentados como média aritmética土 EPM. ${ }^{*} p<0,05$ comparados com o placebo da mesma linhagem; ${ }^{*}<<0,05$ comparados com o SHR na mesma situação de tratamento, segundo a análise de variância de 2 vias (2-way-ANOV A). 1=há interação entre linhagem e tratamento para a área ocupada pela imunorreatividade; $2=a$ linhagem $e \quad 0$ tratamento, separadamente, influenciam a área ocupada pela imunorreatividade; $3=0$ tratamento influencia a intensidade da marcação da imunorreatividade; 4=a linhagem e o tratamento, separadamente, influenciam a intensidade da marcação da imunorreatividade, segundo a análise de variância de 2 vias. $n=6$. 

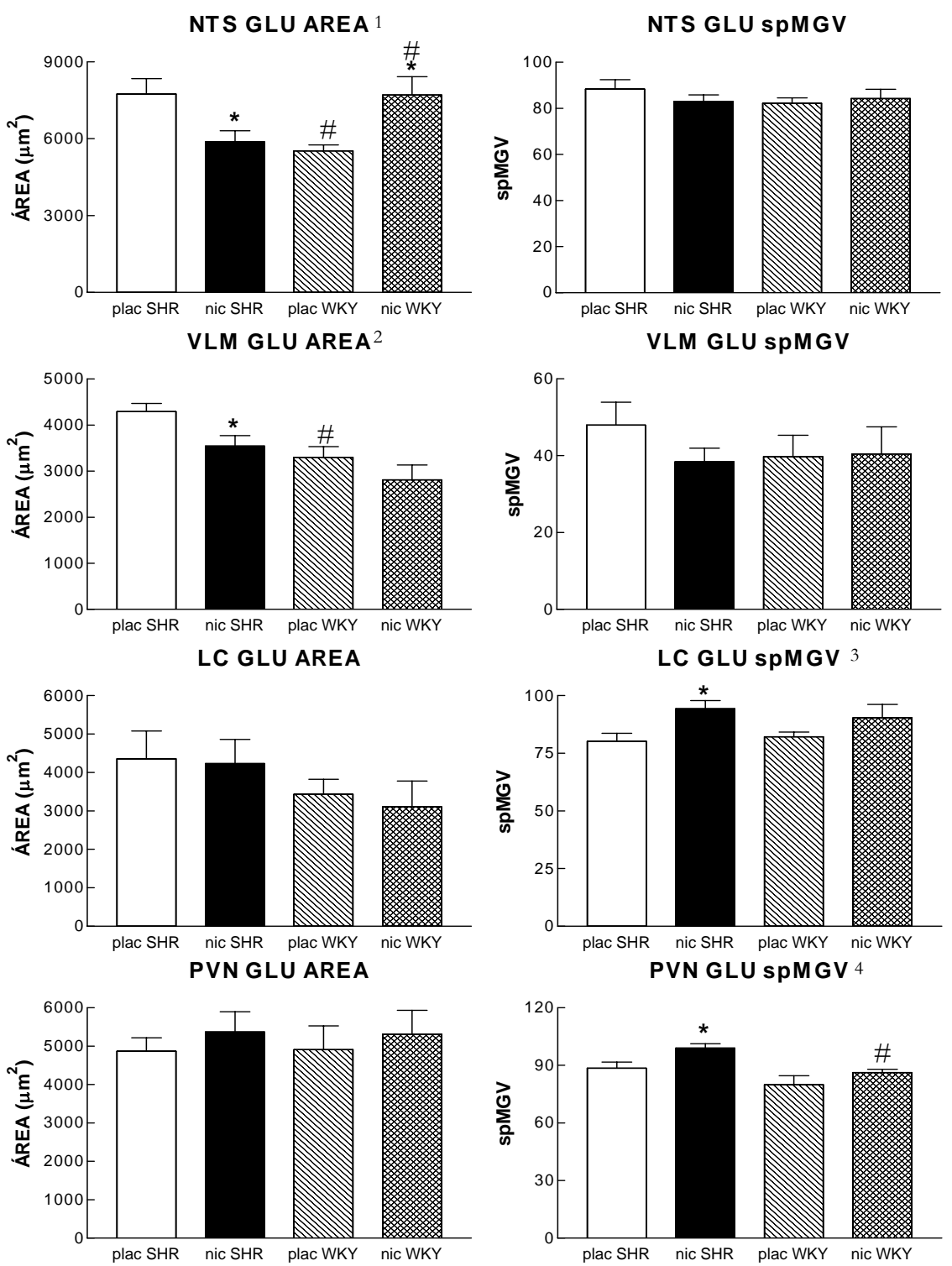

FIGURA 44. spMGV (unidades arbitrárias) e área ocupada pela imunorreatividade ao glutamato (GLU) no núcleo do trato solitário (NTS), medula oblonga ventrolateral (VLM), Locus coeruleus (LC) e núcleo paraventricular hipotalâmico (PVN) de ratos espontaneamente hipertensos (SHR) e Wistar Kyoto (WKY) submetidos a tratamento crônico com nicotina (nic) ou placebo (plac). Os valores são apresentados como média aritmética \pm EPM. ${ }^{*} p<0,05$ comparados com o placebo da mesma linhagem; ${ }^{*} p<0,05$ comparados com o SHR na mesma situação de tratamento, segundo a análise de variância de 2 vias (2-wayANOVA). $1=$ há interação entre linhagem e tratamento para a área ocupada pela imunorreatividade; $2=$ a linhagem e o tratamento, separadamente, influenciam a área ocupada pela imunorreatividade; $3=0$ tratamento influencia a intensidade da marcação da imunorreatividade; $4=$ a linhagem e o tratamento, separadamente, influenciam a intensidade da marcaşão da imunorreatividade, segundo a análise de variância de 2 vias. $n=6$. 

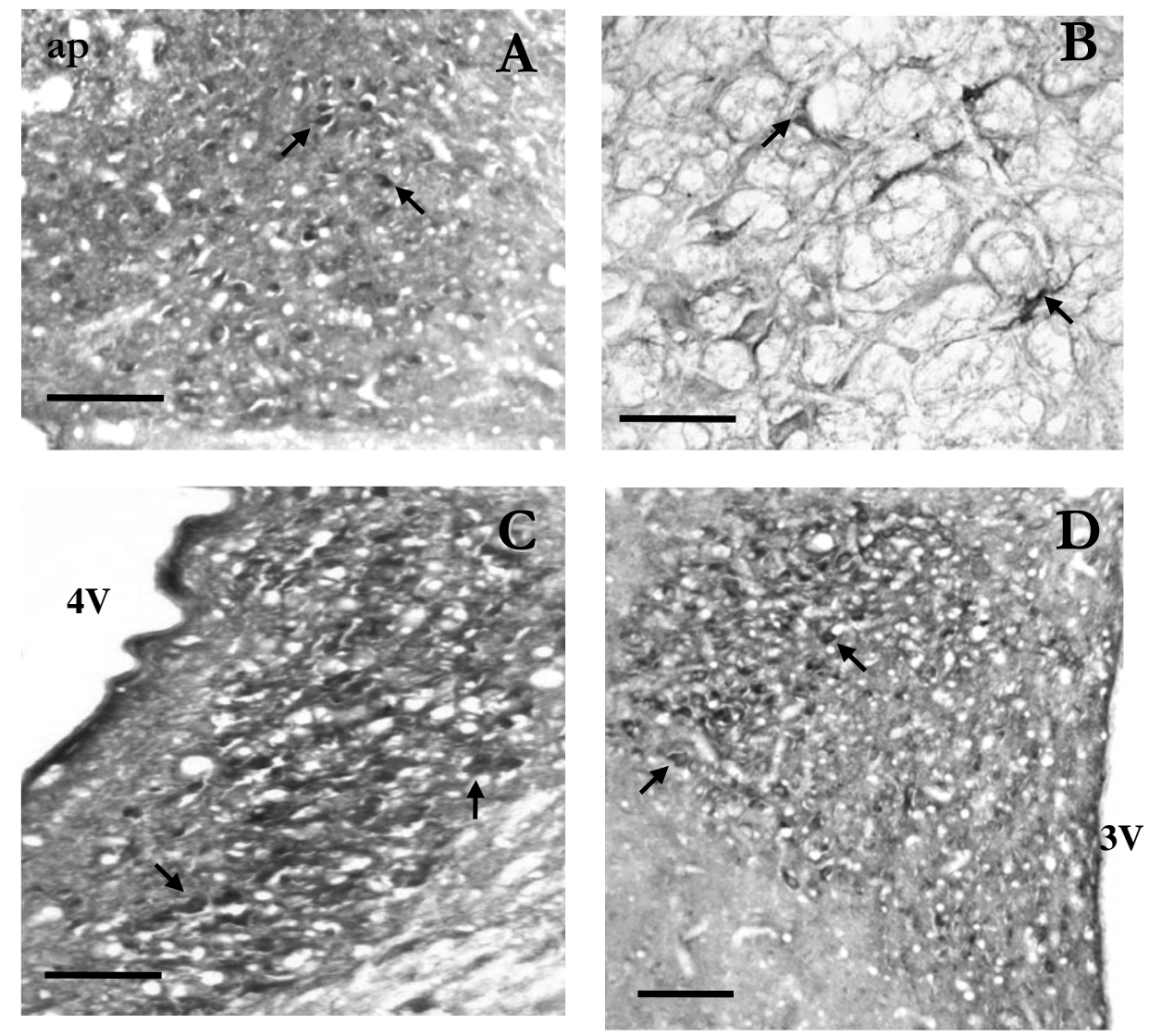

FIGURA 45. Fotomicrografias digitais representativas ilustrando o padrão de marcação da imunorreatividade ao glutamato no núcleo do trato solitário (A), medula oblonga ventrolateral $(\mathbf{B})$, locus coeruleus $(\mathbf{C})$ e núcleo paraventricular do hipotálamo $(\mathbf{D})$. As setas indicam alguns dos perfis celulares considerados na quantificção. Abreviaturas: ap=área postrema, 3V= terceiro ventrículo, 4V= quarto ventrículo. Barra de escala $=50 \mu \mathrm{m}$. 


\subsubsection{Hibridização in situ}

Não houve alteração da expressão do RNAm da glutaminase no NTS, LC ou PVN de ratos tratados com nicotina (Tabela 21 e Figura 46). Além disso, a expressão do RNAm da glutaminase não sofre influência do tratamento com nicotina, linhagem e ratos ou interação entre estes dois parâmetros. O padrão de marcação nos núcleos de estudo pode ser visualizado na figura 47.

Tabela 21. Densidade Óptica Relativa (ROD) da marcação, no filme radiosensível, promovida pela sonda radioativa complementar ao RNAm da glutaminase no núcleo do trato solitário (NTS), locus coeruleus (LC) e núcleo paraventricular hipotalâmico (PVN) de ratos espontaneamente hipertensos (SHR) e Wistar Kyoto (WKY) submetidos a tratamento crônico com nicotina ou placebo.

\begin{tabular}{ccccc}
\hline & NTS & LC & PVN \\
\hline \multirow{2}{*}{ SHR } & Placebo & $0,3275 \pm 0,0386$ & $0,7102 \pm 0,0415$ & $0,2813 \pm 0,0348$ \\
& Nicotina & $0,3485 \pm 0,0248$ & $0,7727 \pm 0,0307$ & $0,2789 \pm 0,0199$ \\
\hline \multirow{2}{*}{ WKY } & Placebo & $0,2992 \pm 0,0292$ & $0,7441 \pm 0,0571$ & $0,3390 \pm 0,0407$ \\
& Nicotina & $0,2796 \pm 0,0260$ & $0,6620 \pm 0,0418$ & $0,2902 \pm 0,0299$ \\
\hline
\end{tabular}

Os valores são apresentados como média aritmética \pm EPM.Empregou-se a análise de variância de 2 vias (2-way-ANOVA) para a análise dos resultados. $n=6$. 


\section{NTS GLUT}
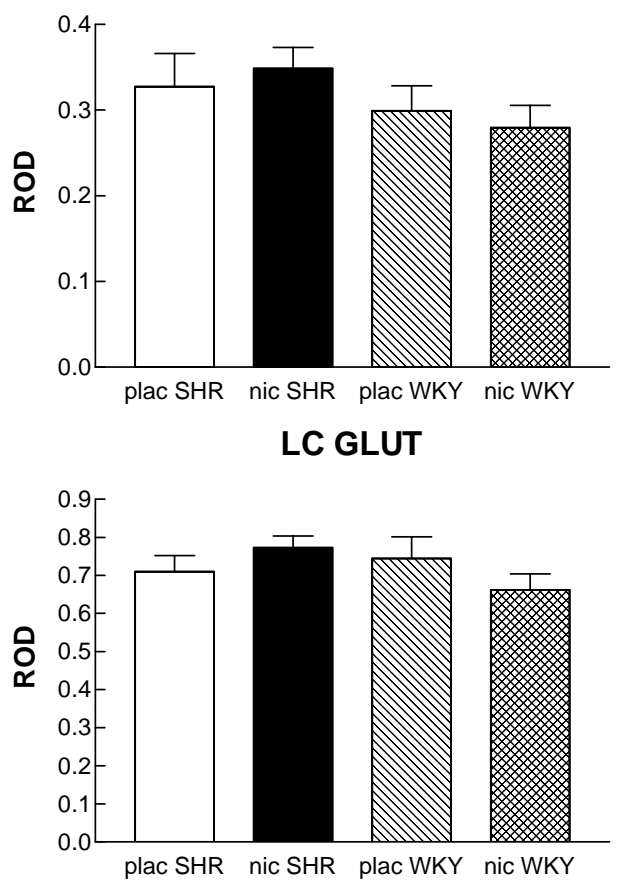

PVN GLUT

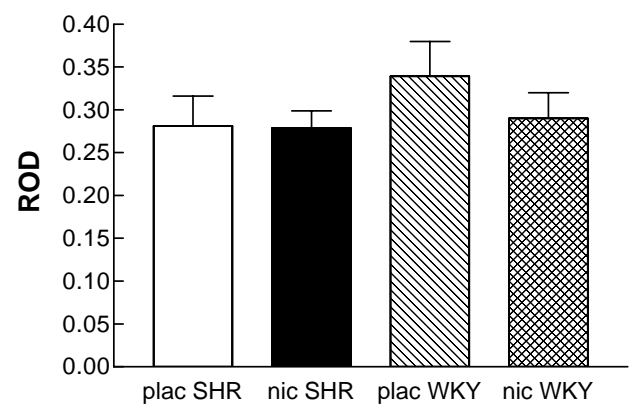

IGURA 46. Densidade Óptica Relativa (ROD) da marcação, no filme radiosensível, promovida pela sonda radioativa complementar ao RNAm da glutaminase no núcleo do trato solitário (NTS), locus coeruleus (LC) e núcleo paraventricular hipotalâmico (PVN) de ratos espontaneamente hipertensos (SHR) e Wistar Kyoto (WKY) submetidos a tratamento crônico com nicotina (nic) ou placebo (plac). Os valores são apresentados como média aritmética \pm EPM.Empregou-se a análise de variância de 2 vias (2-way-ANOV A) para a análise dos resultados. $n=6$. 

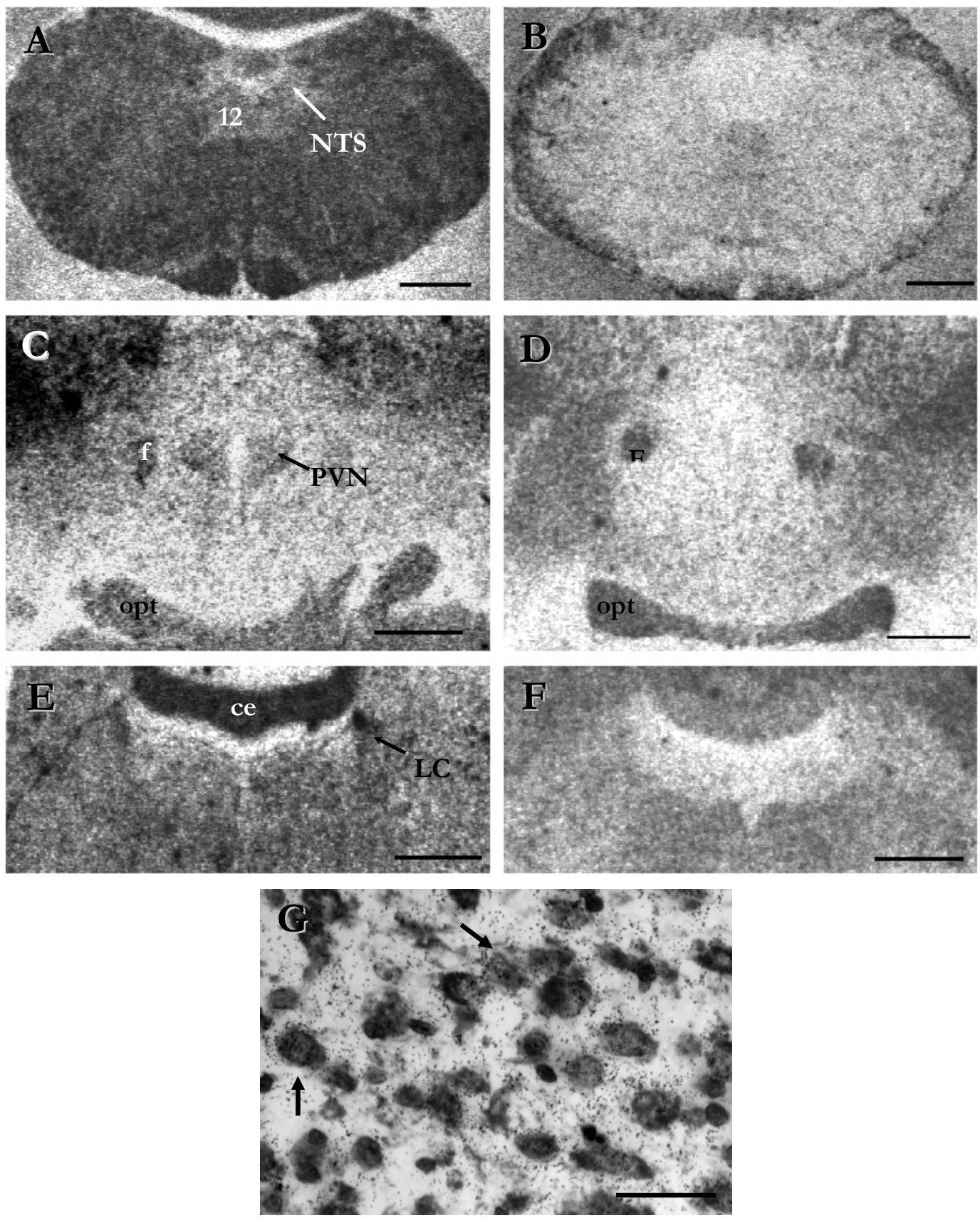

FIGURA 47. Imagens representativas do filme radioautográfico mostrando o padrão de marcação do RNAm da glutaminase por sonda radioativa no núcleo do trato solitário (NTS) (A), núcleo paraventricular hipotalâmico (PVN) (C) e locus coeruleus (LC) (E). Em B, D e $\mathbf{F}$ tem-se a ausência de marcação específica devido ao deslocamento da sonda radioativa por sonda não marcada. Em G observa-se a localização celular da marcação no PVN. Abreviaturas: 12=núcleo hipoglosso, ce=cerebelo, $\mathrm{f}=$ fornix, opt=trato óptico. Barra de escala $=1 \mathrm{~mm}$ e $30 \mu \mathrm{m}(\mathrm{G})$ 


\subsubsection{Análise da Ligação}

Através de experimentos para a padronização da técnica de radioautografia quantitativa, para os receptores ionotrópicos de glutamato, foi possível obter o $\mathrm{K}_{\mathrm{D}}$ (em nM) dos receptores NMDA $(596,05 \pm 125,57)$, KA $(319,55 \pm 61,39)$ e AMPA $(281,05 \pm 56,62)$. Podem-se visualizar exemplos de curvas obtidas na padronização dos experimentos de ligação na figura 48.
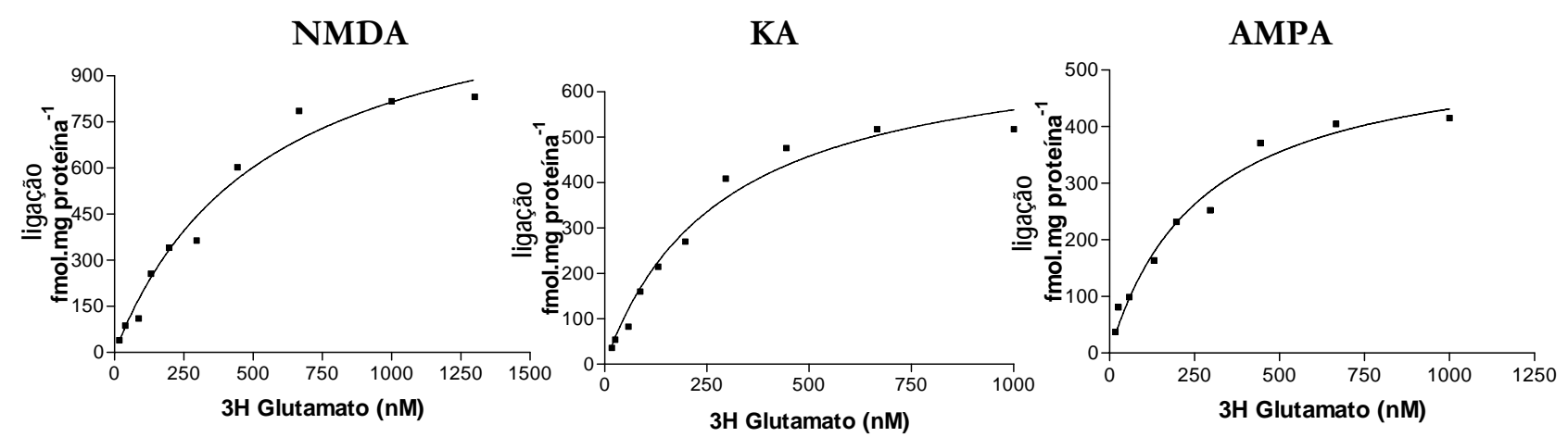

FIGURA 48. Exemplos de curvas de ligação do $\left[{ }^{3} \mathrm{H}\right]$ Glutamato (fmol.mg proteína $^{-1}$ ), obtidas através do método wipe off, aos seus 3 subtipos de receptores ionotrópicos: NMDA $\left(K_{D}=596,05 \pm 125,57\right), K A(319,55 \pm 61,39)$ e AMPA $(281,05 \pm 56,62)$ no núcleo do trato solitário de rato espontaneamente hipertenso (SHR). 
Após a obtenção do $K_{D}$ para cada subtipo de receptor ionotrópico de glutamato, foram feitos os experimentos com os animais experimentais.

Os ratos WKY não apresentaram alteração na ligação dos receptores NMDA, AMPA e de Kainato após tratamento crônico com nicotina em nenhum um dos núcleos analisados, ao passo que os SHR tratados com nicotina tiveram redução na ligação destes receptores no NTS. No LC dos ratos SHR tratados houve diminuição da ligação dos receptores de Kainato e aumento na ligação dos receptores AMPA (Tabela 22 e Figura 49). No PVN dos ratos SHR, o tratamento crônico com nicotina não alterou a ligação dos receptores ionotrópicos de glutamato. Através análise de variância de duas vias foi possível detectar que a ligação dos receptores para kainato encontrou-se diminuída no NTS e LC dos ratos SHR tratados com nicotina em relação aos WKY também tratados. Por outro lado, o PVN dos ratos SHR mostrou-se com maior ligação dos receptores NMDA em relação aos WKY após tratamento com o alcalóide. A ligação dos receptores ionotrópicos para o glutamato é modulada ainda pelo tratamento com nicotina, pela linhagem de rato e pela interação entre estes dois parâmetros.

A figura 50 apresenta o padrão de marcação analisado nos núcleos de estudo, assim como o controle de especificidade do ligante através do deslocamento do ligante radioativo por não marcado em excesso. 
TABELA 22. Ligação do $\left[{ }^{3} \mathrm{H}\right]$ Glutamato (fmol.mg proteína ${ }^{-1}$ ) aos seus receptores ionotrópicos (NMDA, KA e AMPA) no núcleo do trato solitário (NTS), locus coeruleus (LC) e núcleo paraventricular hipotalâmico (PVN) de ratos espontaneamente hipertensos (SHR) e Wistar Kyoto (WKY) submetidos a tratamento crônico com nicotina ou placebo.

\begin{tabular}{|c|c|c|c|c|c|}
\hline & & \multicolumn{2}{|c|}{ SHR } & \multicolumn{2}{|c|}{ WKY } \\
\hline & & placebo & Nicotina & placebo & Nicotina \\
\hline \multirow{3}{*}{ NTS } & $\mathrm{NMDA}^{1}$ & $695,50 \pm 33,13$ & $557,90 \pm 21,42^{* *}$ & $617,00 \pm 49,37$ & $612,80 \pm 9,41$ \\
\hline & KA & $378,10 \pm 19,08$ & $325,30 \pm 7,75^{*}$ & $383,30 \pm 16,60$ & $383,70 \pm 14,34^{\ddagger}$ \\
\hline & AMPA & $403,50 \pm 15,45$ & $346,90 \pm 19,26^{\mathrm{t}}$ & $378,90 \pm 20,99$ & $374,80 \pm 19,69$ \\
\hline \multirow{3}{*}{ LC } & NMDA & $589,40 \pm 32,25$ & $572,50 \pm 33,58$ & $512,20 \pm 18,77$ & $556,00 \pm 26,66$ \\
\hline & $\mathbf{K A}^{2}$ & $387,00 \pm 13,38$ & $257,60 \pm 5,95^{* * *}$ & $340,70 \pm 20,94$ & $368,90 \pm 14,82^{\ddagger}$ \\
\hline & $\mathbf{A M P A}^{3}$ & $233,10 \pm 18,09$ & $336,20 \pm 27,60 *$ & $224,20 \pm 24,52$ & $244,80 \pm 24,96$ \\
\hline \multirow{3}{*}{ PVN } & $\mathbf{N M D A}^{3}$ & $476,09 \pm 28,63$ & $439,40 \pm 34,85$ & $307,60 \pm 28,98^{\#}$ & $383,40 \pm 39,47$ \\
\hline & KA & $235,10 \pm 9,27$ & $248,10 \pm 15,83$ & $226,10 \pm 19,22$ & $235,30 \pm 10,91$ \\
\hline & AMPA & $235,40 \pm 21,64$ & $243,30 \pm 35,90$ & $210,00 \pm 46,42$ & $214,00 \pm 23,04$ \\
\hline
\end{tabular}

Os valores são apresentados como média aritmética土 EPM. * ${ }^{*}<0,05$; *** $p<0,0001 ;{ }^{\mathrm{t}} p=0,05$ comparados com o placebo da mesma linhagem; ${ }^{*} p<0,05$ comparados com SHR na mesma condição de tratamento, segundo a análise de variância de 2 vias (2-way-ANOVA). $1=$ influência do tratamento, sozinho, $e$ da interação entre linhagem e tratamento na ligação; $2=a$ linhagem e 0 tratamento, individualmente, assim como a interação entre estes influenciam a ligação; 3 = a linhagem influencia a ligação, segundo a análise de variância de 2 vias. $n=6$. 
NTS NMDA ${ }^{1}$

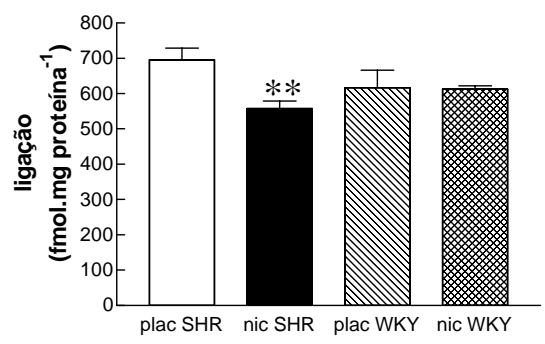

LC NMDA

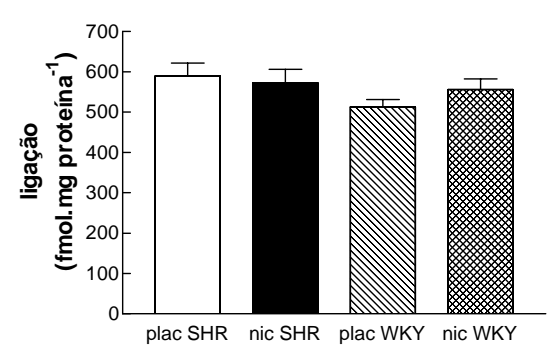

PVN NMDA $^{3}$

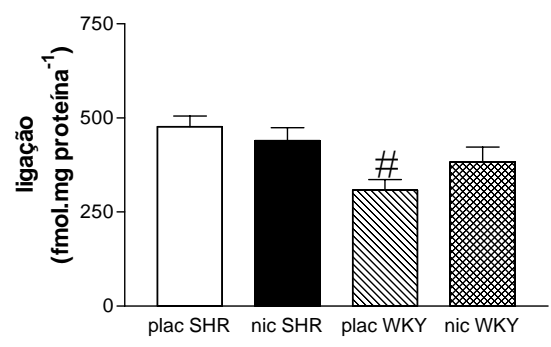

NTS AMPA

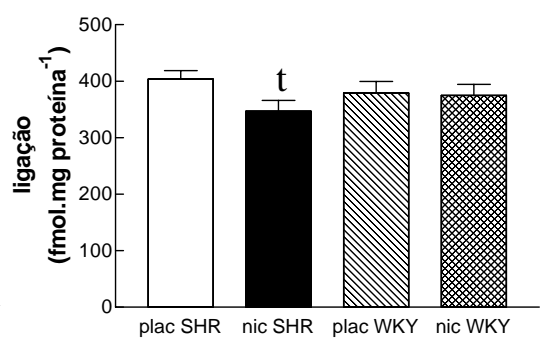

LC AMPA ${ }^{3}$

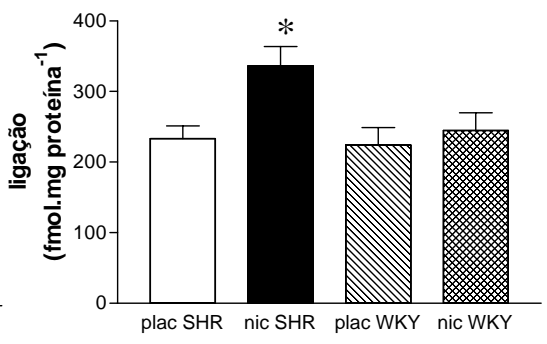

PVN KA

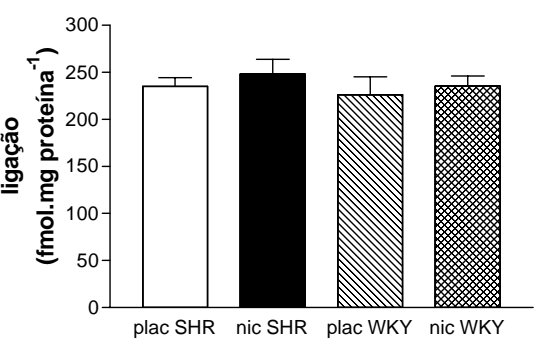

NTS KA

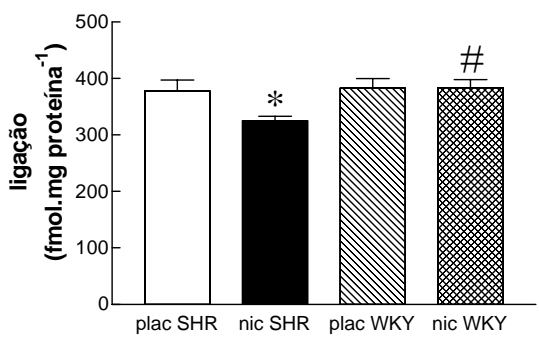

LC KA $^{2}$

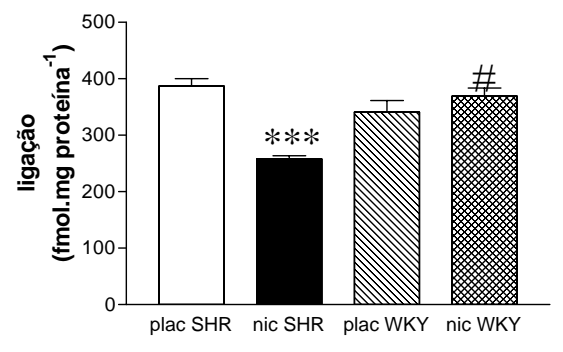

PVN AMPA

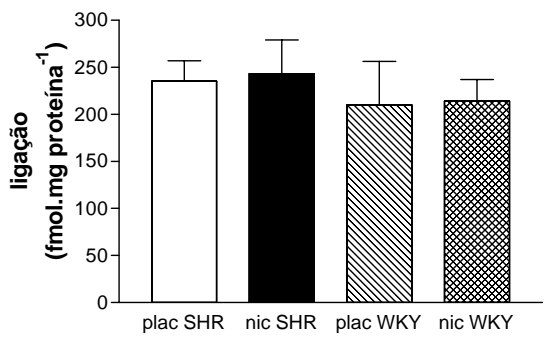

FIGURA 49. Ligação do $\left[{ }^{3} \mathrm{H}\right]$ Glutamato (fmol.mg proteína ${ }^{-1}$ ) aos seus receptores ionotrópicos (NMDA, KA e AMPA) no núcleo do trato solitário (NTS), locus coeruleus (LC) e núcleo paraventricular hipotalâmico (PVN) de ratos espontaneamente hipertensos (SHR) e Wistar Kyoto (WKY) submetidos a tratamento crônico com nicotina (nic) ou placebo (plac). Os valores são apresentados como média aritmética士 EPM. ${ }^{*} p<0,05 ; * * * p<0,0001 ;{ }^{\mathrm{t}} p=0,05$ comparados com 0 placebo da mesma linhagem; ${ }^{*} p<0,05$ comparados com SHR na mesma condição de tratamento, segundo a análise de variância de 2 vias (2-way-ANOVA). 1= influência do tratamento, soz̧inho, e da interação entre linhagem e tratamento na ligação; 2=a linhagem e o tratamento, sozinho, assim como a interação entre estes influenciam a ligação; $3=$ a linhagem influencia a ligação, segundo a análise de variância de 2 vias (2-way-ANOVA). $n=6$. 
AMPA
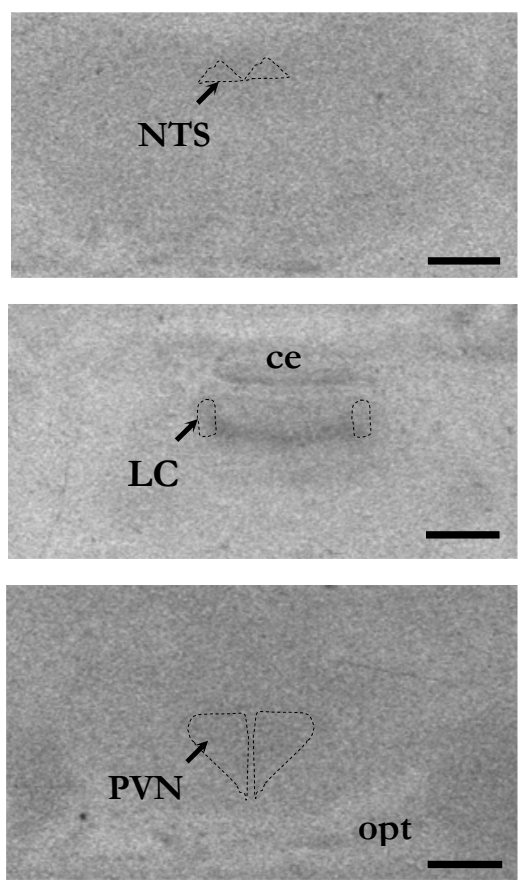

não esp. NTS
KA

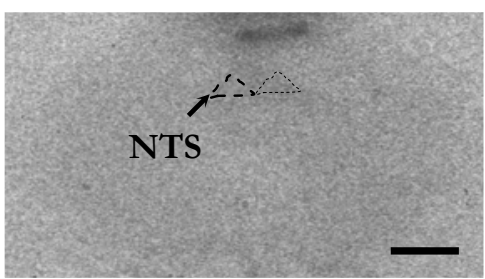

ce
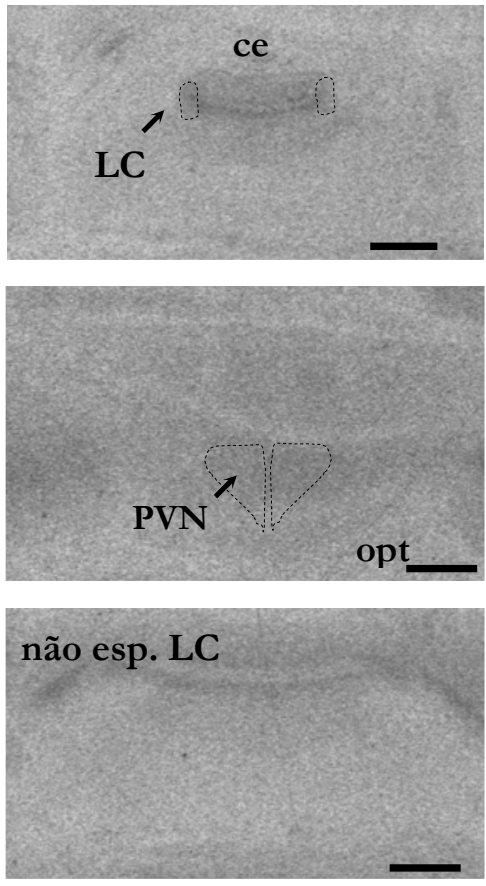

NMDA

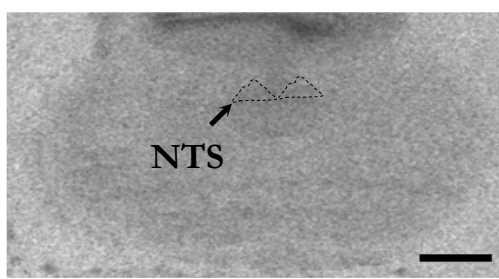

ce
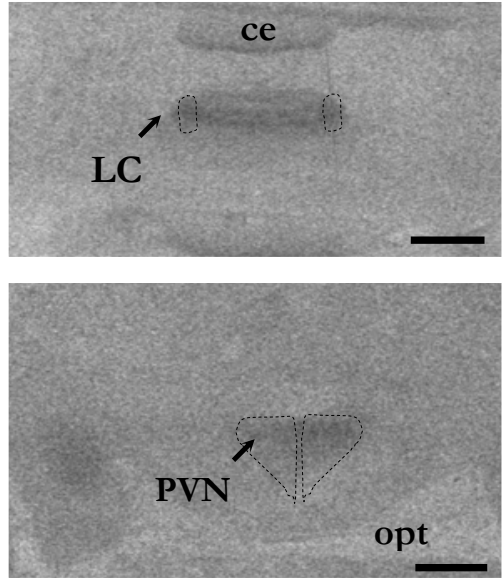

não esp. PVN

FIGURA 50. Imagens representativas do filme radioautográfico mostrando o padrão de marcação dos receptores ionotrópicos de glutamato (AMPA, KA e NMDA) pelo ligante $\left.{ }^{3} \mathrm{H}\right]$ Glutamato no núcleo do trato solitário (NTS), locus coeruleus (LC) e núcleo paraventricular do hipotálamo (PVN). Na última linha tem-se a ausência de marcação específica devido ao deslocamento do ligante radioativo por agonistas específicos dos receptores de glutamato não marcados. Barra de escala $=1 \mathrm{~mm}$. Abreviaturas: $\mathrm{ce}=$ cerebelo, $\mathrm{opt}=$ trato óptico. 


\subsection{Caracterização da Cultura de Células}

A caracterização da cultura de células deu-se através de imunocitoquímica onde se marcou uma proteína específica presente em astrócitos (GFAP) ou a NeuN, proteína nuclear de neurônios, assim como todas as células da cultura através do corante DAPI, presente no meio de montagem, que gera fluorescência azul ao ligar-se ao DNA e, portanto, marca todos os núcleos celulares.

A figura 51 ilustra o padrão de marcação obtido na caracterização das culturas de células gliais e neurônios. Pode-se notar a homogeneidade das culturas tornando-as adequadas para a experimentação. Há grande concentração de células gliais ou neurônios, contendo dupla marcação (GFAP ou NeuN com DAPI), comparado com os demais tipos celulares (marcados somente com DAPI). 


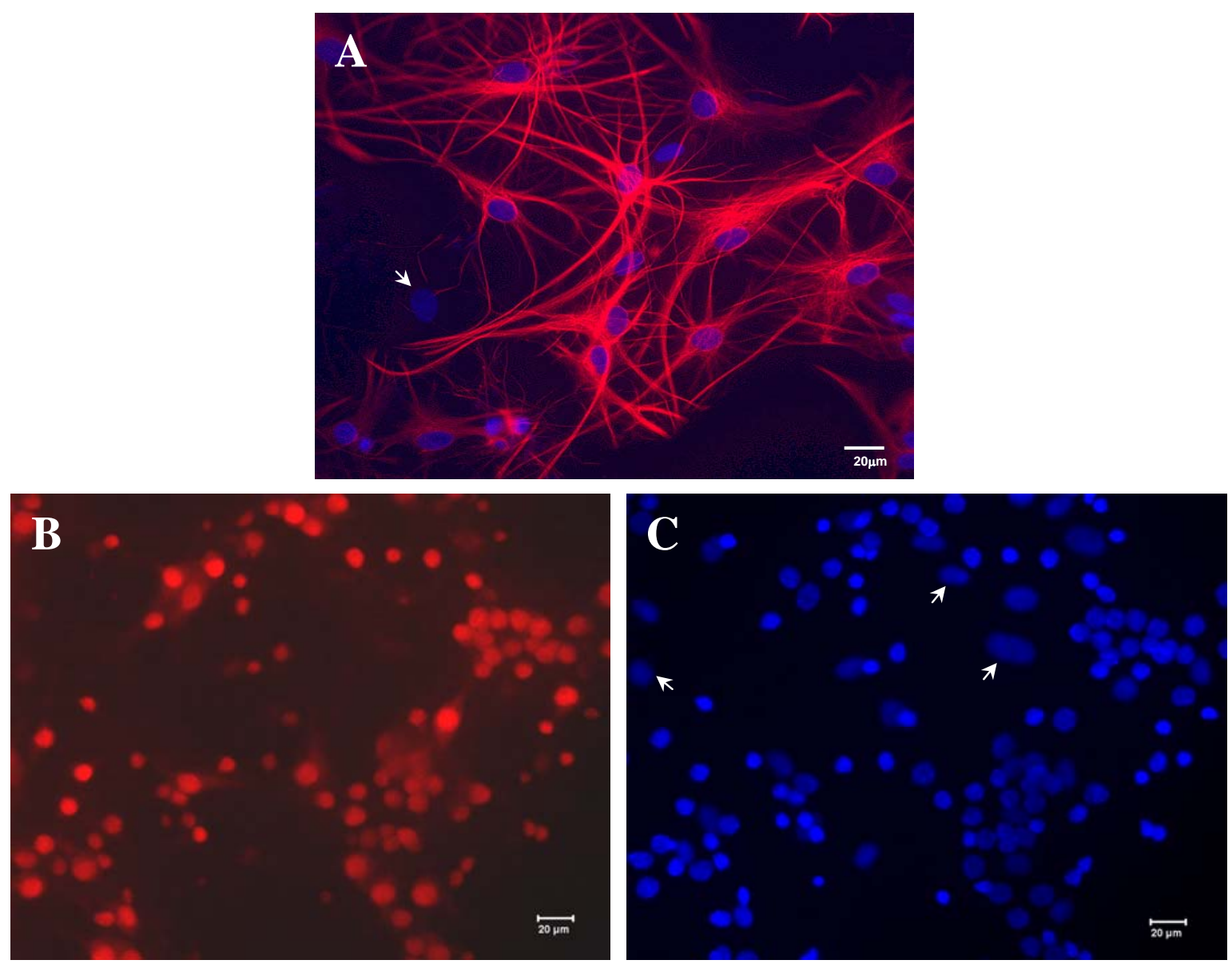

FIGURA 51. Fotomicrografias digitais ilustrando a caracterização da cultura de células gliais (A) e neuronais (B e C). Pode-se notar a homogeneidade das culturas, pois há co-localização quase que total das células marcadas com GFAP (A) ou NeuN (B) (vermelho) com o marcador nuclear (DAPI, em azul). Algumas das poucas células negativas para o GFAP ou NeuN estão indicadas com setas. 


\subsection{Análise da Ligação dos Receptores $\mathbf{A T}_{1}$ e $\mathbf{A T}_{2}$ de} Angiotensina II.

O sistema angiotensinérgico em ratos SHR parece ser mais sensível às ações da nicotina que em WKY já que a ligação nos receptores $\mathrm{AT}_{1}$ e $\mathrm{AT}_{2}$ modificou-se mais intensamente em cultura de células gliais e neuronais dos primeiros (Tabela 23 e Figura 52).

O tratamento com nicotina promoveu aumento na ligação dos receptores $\mathrm{AT}_{1}$ em glia e neurônios em co-cultura de tronco encefálico/hipotálamo somente de SHR em todas as doses de nicotina (1, 10 e $100 \mu \mathrm{M})$. A análise temporal demonstrou que a ligação aos receptores $\mathrm{AT}_{1}$ em neurônios alterou-se a partir de 4 horas, já em glia a alteração aconteceu a partir de 12 horas de tratamento. Houve aumento da ligação aos receptores $\mathrm{AT}_{2}$ de neurônios somente com 12 horas de tratamento com $10 \mu \mathrm{M}$ de nicotina (curva temporal) ou com a dose de $100 \mu \mathrm{M}$ no estudo dose-resposta (Tabela 23 e Figura 52). Portanto, somente células de SHR responderam ao tratamento com nicotina quando em co-cultura de tronco encefálico e hipotálamo.

Foram feitas culturas separadas de células gliais do tronco encefálico e hipotálamo e estas tratadas com nicotina e submetidas à análise da ligação dos receptores $\mathrm{AT}_{1}$.

Em células gliais do hipotálamo, a ligação diminuiu em SHR após 24 horas com 1 e $10 \mu \mathrm{M}$ de nicotina, ao passo que em WKY a diminuição da ligação ocorreu somente com $100 \mu \mathrm{M}$ de nicotina. Após 4 horas expostas a $10 \mu \mathrm{M}$ de nicotina, houve diminuição da ligação em células gliais de WKY, enquanto que nos SHR esta diminuição aconteceu a partir de 12 horas de tratamento e perdurou até 24 horas de exposição quando voltou ao estado controle às 48 horas de tratamento (Tabela 23 e Figura 52). 
No tronco encefálico, a nicotina promoveu aumento da ligação dos receptores $\mathrm{AT}_{1}$ em SHR após 1, 10 e $100 \mu \mathrm{M}$ de nicotina, ao passo que em WKY $100 \mu \mathrm{M}$ de nicotina promoveu diminuição da ligação. A análise temporal demonstrou aumento da ligação com administração de $10 \mu \mathrm{M}$ de nicotina após 24 e 48 horas de exposição à droga tanto em células de SHR quanto de WKY (Tabela 23 e Figura 52).

Outro resultado importante foi a constatação da menor ligação em células gliais de SHR comparados com WKY, no entanto em neurônios, a ligação é maior em SHR. 
TABELA 23. Ligação dos receptores $\mathrm{AT}_{1}$ e $\mathrm{AT}_{2}$ de angiotensina II em cultura de células gliais e neuronais de ratos espontaneamente hipertensos (SHR) e Wistar Kyoto (WKY, normotensos) após tratamento com nicotina $(10 \mu \mathrm{M})$ durante 4, 12, 24 e 48h (curva temporal), ou 1, 10 e $100 \mu \mathrm{M}$ por 24 horas (dose-resposta).

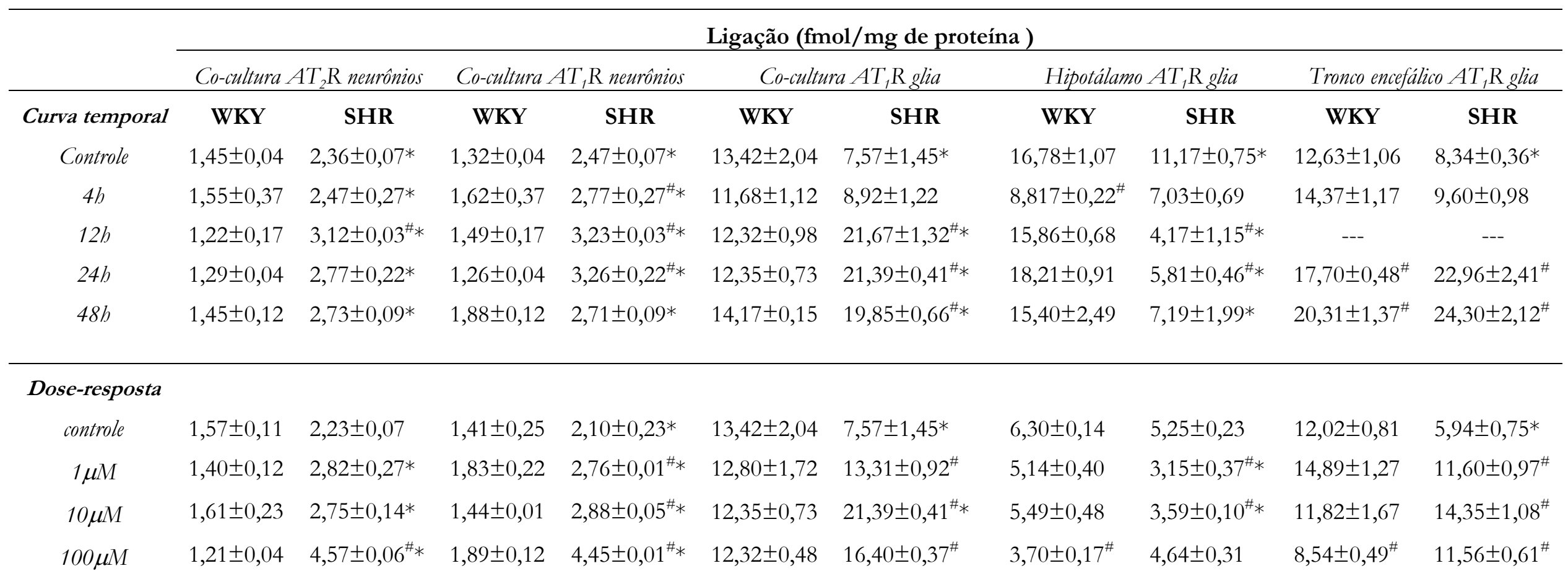

Os valores estão representados como média aritmética \pm EPM. Tanto o tratamento quanto a linhagem influenciam a ligação. ${ }^{\#} p<0,05$ comparado com controle da mesma linhagem, * ${ }^{*}<0,05$ comparado com WKY na mesma situação, segundo a análise de variância (ANOVA) de duas vias seguida do pós-teste de Bonferroni. 


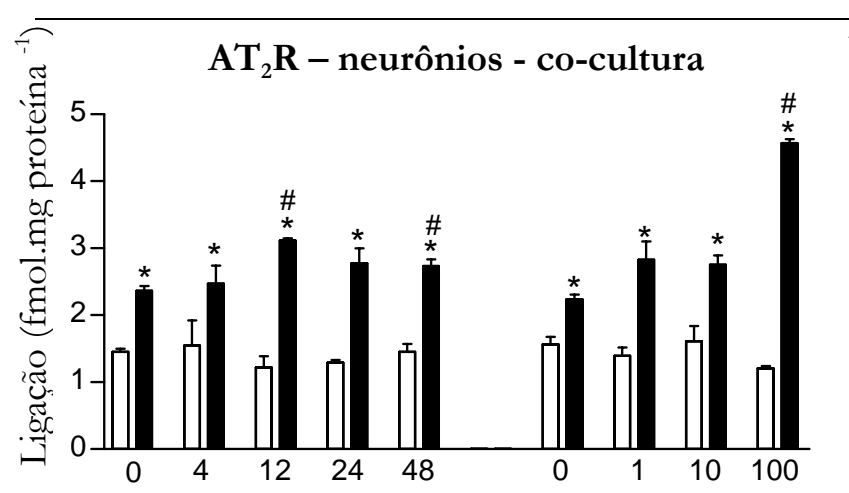

Curva temporal (horas)

Dose-resposta $(\mu \mathrm{M})$

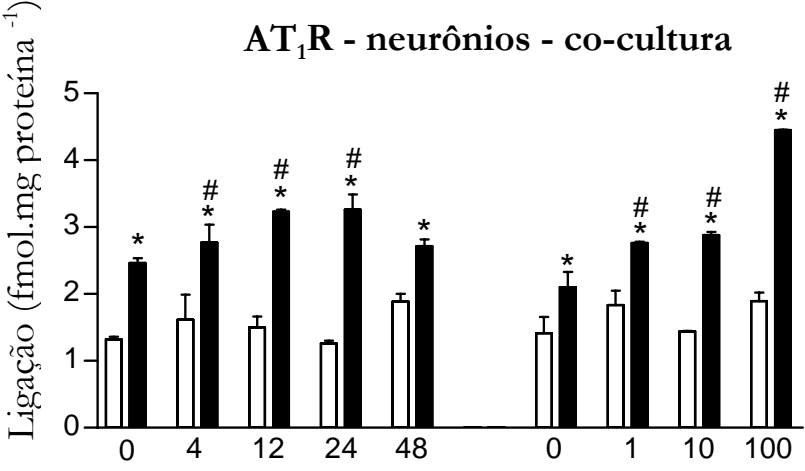

Curva temporal (horas) Dose-resposta $(\mu \mathrm{M})$

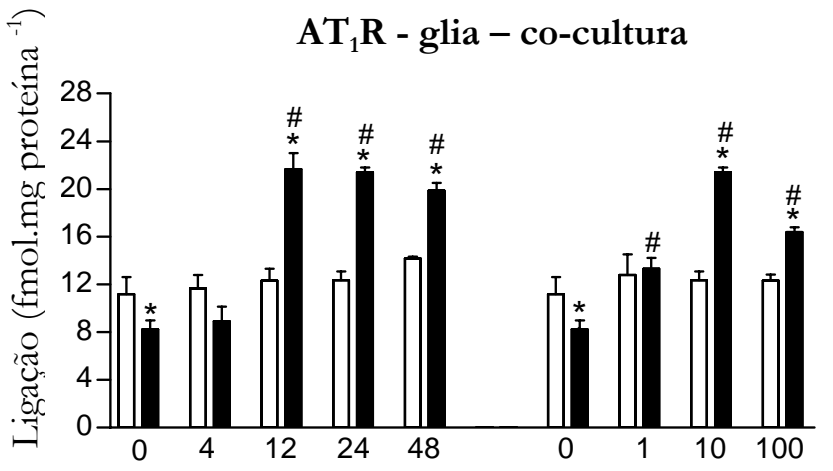

Curva temporal (horas)

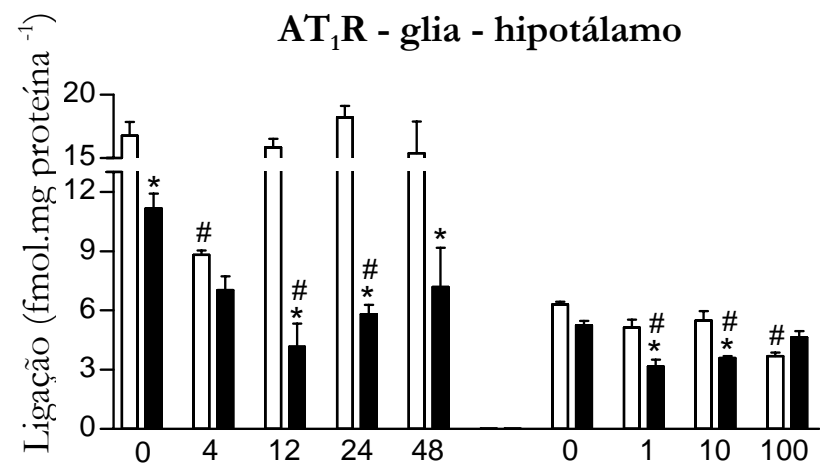

Curva temporal (horas)

Dose-resposta $(\mu \mathrm{M})$

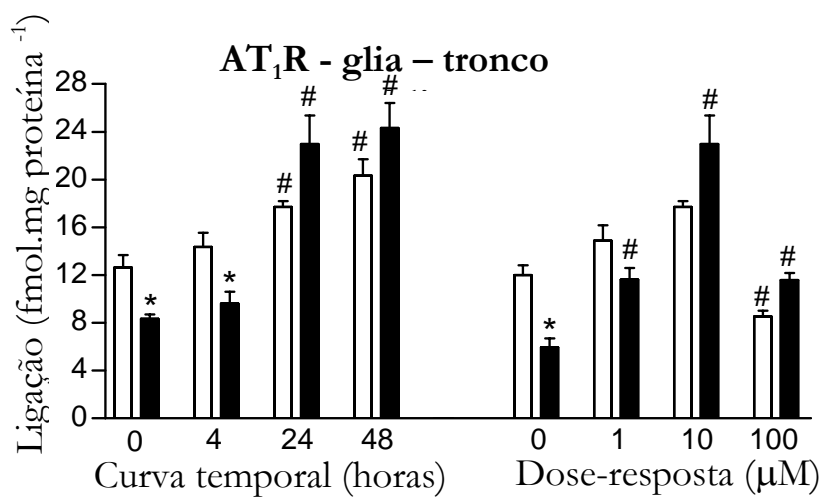

FIGURA 52. Ligação dos receptores $\mathrm{AT}_{1}$ e $\mathrm{AT}_{2}$ de angiotensina II em cultura de células neuronais e gliais do hipotálamo, tronco encefálico ou co-cultura hipotálamo/tronco encefálico de ratos espontaneamente hipertensos (SHR, barras pretas) e Wistar Kyoto (WKY, normotensos, barras brancas) após tratamento com nicotina $(10 \mu \mathrm{M})$ durante 4, 12, 24 e 48 horas (curva temporal) ou 1, 10 e $100 \mu \mathrm{M}$ por 24 horas (curva dose-resposta). Os valores estão representados como média aritmética \pm EPM. Tanto o tratamento quanto a linhagem influenciam a ligação. ${ }^{*} p<0,05$ comparado com controle da mesma linhagem, ${ }^{*} p<0,05$ comparado com WKY na mesma situação, segundo a análise de variância (ANOVA) de duas vias seguida do pós-teste de

\section{Bonferroni}




\subsection{Avaliação de RNAm do sistema angiotensinérgico por PCR em Tempo Real.}

O tratamento com nicotina promoveu diminuição do RNAm do angiotensinogênio em co-cultura de neurônios tanto de SHR quanto de WKY. O efeito foi observado após 12 horas de tratamento perdurando até pelo menos 48 horas. A dose de $1 \mu \mathrm{M}$ foi suficiente para promover a queda nos níveis de RNAm do angiotensinogênio em neurônios das duas linhagens o que

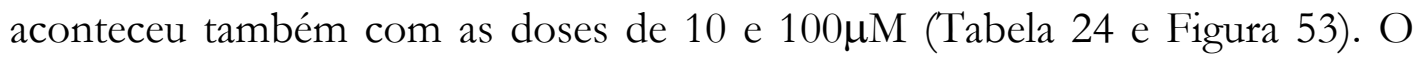
RNAm do angiotensinogênio também diminuiu em células gliais em co-cultura de SHR e WKY tratadas com nicotina, no entanto o efeito da nicotina mostrou-se mais potente sobre as células provenientes de ratos hipertensos pois o efeito foi observado já com a dose de $1 \mu \mathrm{M}$ assim como após 4 horas de tratamento com $10 \mu \mathrm{M}$ da droga. A diminuição dos níveis de RNAm do angiotensinogênio em co-cultura de células gliais de WKY aconteceu somente com $10 \mu \mathrm{M}$ de nicotina e a partir de 12 horas de tratamento.

Células gliais de tronco encefálico em cultura também apresentaram diminuição do RNAm do angiotensinogênio após tratamento com nicotina, no entanto as alterações foram mais pronunciadas nas células do rato normotenso. 1 e $10 \mu \mathrm{M}$ de nicotina diminuíram o RNAm do angiotensinogênio em WKY, ao passo que somente a dose de $100 \mu \mathrm{M}$ fez com que o RNAm de estudo diminuísse no rato hipertenso. No estudo temporal, células gliais de tronco encefálico de SHR não sofreram alterações com a nicotina, no entanto em WKY a nicotina diminuiu os níveis de RNAm do angiotensinogênio pós 12, 24 e 48 horas de exposição à droga (Tabela 24 e Figura 53).

$\mathrm{Na}$ cultura de células gliais do hipotálamo de ratos SHR foi observado aumento no RNAm do angiotensinogênio após 48 horas de tratamento com nicotina. Já em ratos normotensos, a nicotina promoveu diminuição do RNAm 
do angiotensinogênio após 12 e 24 horas de tratamento com $10 \mu \mathrm{M}$ de nicotina (Tabela 24 e Figura 53).

A quantidade de RNAm do angiotensinogênio em células gliais de WKY é significantemente maior (cerca de 2 vezes) que em SHR tanto em tronco encefálico quanto em hipotálamo ou nas duas áreas reunidas numa mesma cultura. Esta situação só não acontece quando há diminuição da expressão do RNAm do angiotensinogênio em ratos WKY (Tabela 24 e Figura 53). 
TABELA 24. Variação na expressão do RNAm do angiotensinogênio em cultura de células gliais e neuronais de ratos espontaneamente hipertensos (SHR) e Wistar Kyoto (WKY, normotensos) após tratamento com nicotina (10 $\mu \mathrm{M})$ durante 4, 12, 24 e 48h (curva temporal), ou 1, 10 e $100 \mu \mathrm{M}$ por 24 horas (dose-resposta).

\begin{tabular}{|c|c|c|c|c|c|c|c|c|}
\hline \multirow[b]{3}{*}{ Curva temporal } & \multicolumn{8}{|c|}{ Variação na expressão (vezes) } \\
\hline & \multicolumn{2}{|c|}{ Co-cultura - neurônios } & \multicolumn{2}{|c|}{ Co-cultura-glia } & \multicolumn{2}{|c|}{ Hipotálamo - glia } & \multicolumn{2}{|c|}{ Tronco encefálico - glia } \\
\hline & WKY & SHR & WKY & SHR & WKY & SHR & WKY & SHR \\
\hline controle & $1,000 \pm 0,000$ & $1,239 \pm 0,174$ & $1,000 \pm 0,000$ & $0,758 \pm 0,021 *$ & $1,000 \pm 0,000$ & $0,396 \pm 0,019 *$ & $1,000 \pm 0,000$ & $0,278 \pm 0,021 *$ \\
\hline $4 b$ & $0,932 \pm 0,096$ & $1,179 \pm 0,069$ & $1,117 \pm 0,007$ & $0,410 \pm 0,034^{* \#}$ & $1,001 \pm 0,074$ & $0,644 \pm 0,0191 *$ & $0,830 \pm 0,034$ & $0,264 \pm 0,014 *$ \\
\hline $12 b$ & $0,499 \pm 0,067^{\#}$ & $0,418 \pm 0,072^{\#}$ & $0,451 \pm 0,015^{\#}$ & $0,159 \pm 0,005^{* \#}$ & $0,630 \pm 0,046^{\#}$ & $0,476 \pm 0,075$ & $0,399 \pm 0,009^{\#}$ & $0,248 \pm 0,043$ \\
\hline $24 h$ & $0,391 \pm 0,015^{\#}$ & $0,266 \pm 0,031^{\#}$ & $0,296 \pm 0,011^{\#}$ & $0,148 \pm 0,003^{* \#}$ & $0,205 \pm 0,023^{\#}$ & $0,580 \pm 0,022 *$ & $0,623 \pm 0,074^{\#}$ & $0,210 \pm 0,015^{*}$ \\
\hline \multicolumn{9}{|l|}{ Dose-resposta } \\
\hline controle & $1,000 \pm 0,000$ & $1,239 \pm 0,174$ & $1,000 \pm 0,000$ & $0,758 \pm 0,021 *$ & $1,000 \pm 0,000$ & $0,396 \pm 0,019 *$ & $1,000 \pm 0,000$ & $0,278 \pm 0,021 *$ \\
\hline $1 \mu M$ & $0,732 \pm 0,021^{\#}$ & $0,3612 \pm 0,053^{\#} *$ & $1,080 \pm 0,029$ & $0,551 \pm 0,019 * \#$ & $0,967 \pm 0,050$ & $0,589 \pm 0,023^{*}$ & $0,462 \pm 0,018^{\#}$ & $0,226 \pm 0,011^{*}$ \\
\hline $10 \mu M$ & $0,391 \pm 0,015^{\#}$ & $0,266 \pm 0,031^{\# *}$ & $0,296 \pm 0,011^{\#}$ & $0,148 \pm 0,003^{* \#}$ & $0,205 \pm 0,023^{\#}$ & $0,580 \pm 0,022 *$ & $0,623 \pm 0,074^{\#}$ & $0,210 \pm 0,015^{*}$ \\
\hline
\end{tabular}

Os valores estão representados como média aritmética \pm EPM. ${ }^{*} p<0,05$ comparado com controle da mesma linhagem, *p<0,05 comparado com WKY na mesma situação, segundo a análise de variância (ANOV A) de duas vias seguida do pós-teste de Bonferroni. 

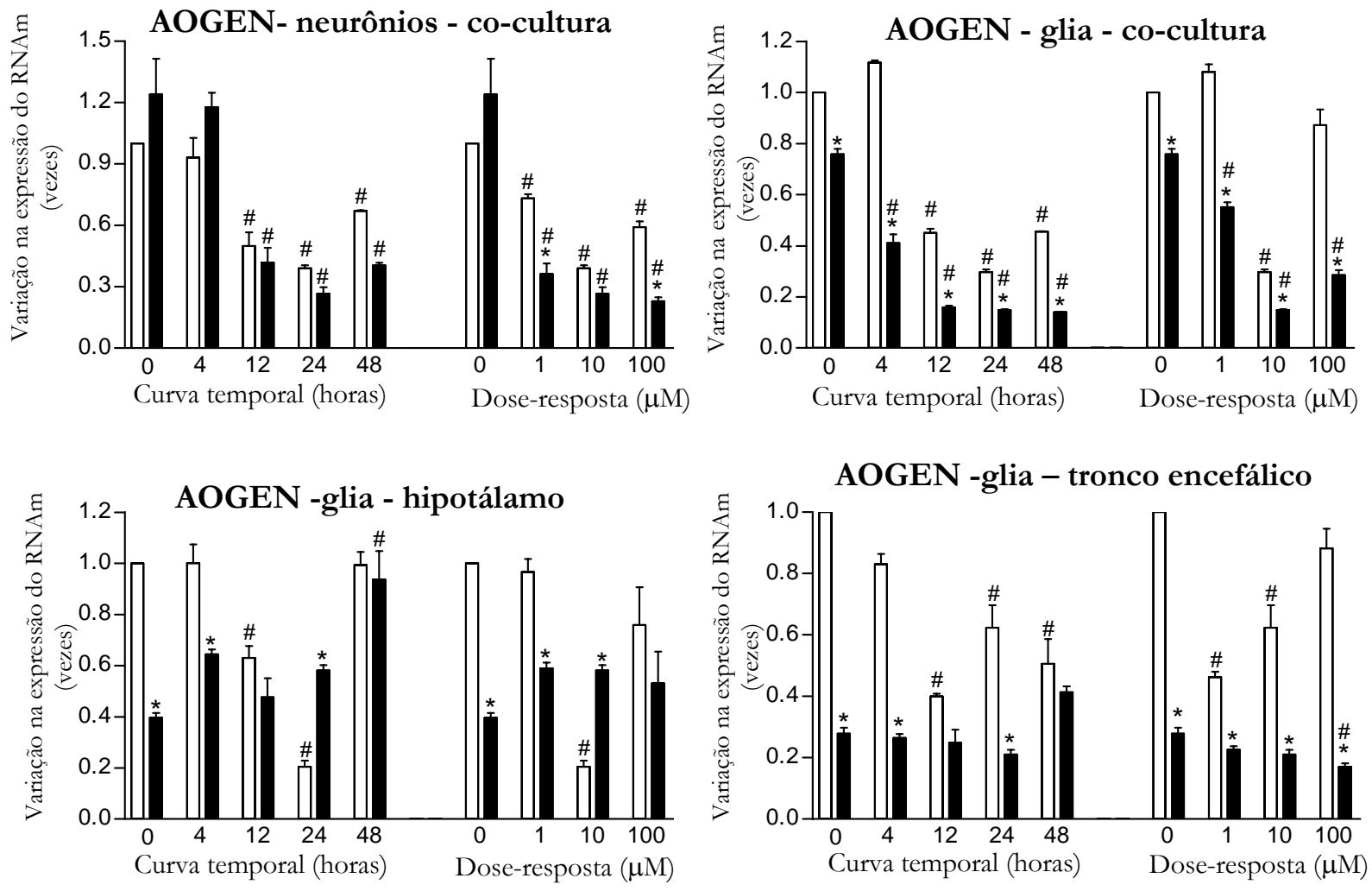

FIGURA 53. Variação na expressão do RNAm do angiotensinogênio em cultura de células neuronais e gliais do hipotálamo, tronco encefálico ou cocultura hipotálamo/tronco encefálico de ratos espontaneamente hipertensos (SHR, barras pretas) e Wistar Kyoto (WKY, normotensos, barras brancas) após tratamento com nicotina $(10 \mu \mathrm{M})$ durante $4,12,24$ e 48 horas (curva temporal) ou 1, 10 e $100 \mu \mathrm{M}$ por 24 horas (curva dose-resposta). Os valores estão representados como média aritmética $\pm E P M .{ }^{*} p<0,05$ comparado com controle da mesma linhagem, ${ }^{*} p<0,05$ comparado com WKY na mesma situação, segundo a análise de variância $(A N O V A)$ de duas vias seguida do pós-teste de Bonferroni. 
A dose de $10 \mu \mathrm{M}$ de nicotina promoveu diminuição do RNAm da enzima conversora de angiotensina (ECA) em co-cultura de neurônios somente de WKY após 12, 24 e 48 horas de tratamento. Assim como em cocultura de células gliais de WKY e SHR após 12 horas ou 24 horas em WKY, com $10 \mu \mathrm{M}$ de nicotina. Por outro lado, 1 e $100 \mu \mathrm{M}$ de nicotina aumentaram a quantidade de RNAm da ECA em co-cultura de glia de WKY (Tabela 25 e Figura 54).

Células gliais do tronco encefálico tiveram o RNAm da ECA aumentado com 10 e $100 \mu \mathrm{M}$ de nicotina e por 24 e 48 horas em SHR e somente com $100 \mu \mathrm{M}$ para WKY (Tabela 25 e Figura 54).

$\mathrm{Na}$ cultura de células gliais do hipotálamo de WKY, a nicotina promoveu diminuição do RNAm da ECA já após 4 horas de exposição permanecendo desta forma até o final do experimento (48 horas). O efeito da nicotina sobre glia de hipotálamo de SHR foi oposto ao observado em WKY: aumento do RNAm da ECA após 12 e 24 horas de tratamento com $10 \mu \mathrm{M}$ (Tabela 25 e Figura 54).

A quantidade basal de RNAm da ECA também difere entre o rato hipertenso e o normotenso. Células gliais do tronco encefálico de ratos SHR possuem maior quantidade da enzima conversora de angiotensina que de WKY. No entanto, a cultura primária de células gliais do hipotálamo de SHR apresenta menos RNAm da ECA comparado com células gliais do mesmo núcleo de WKY. Na co-cultura a diferença na expressão do RNAm da ECA não existe, tanto para células da glia quanto em neurônios.

Em alguns momentos do tratamento com nicotina esta diferença fisiológica na quantidade de RNAm desaparece ou ainda se inverteu como após 12, 24 e 48 horas de tratamento de células gliais do hipotálamo com $10 \mu \mathrm{M}$ de nicotina. 
No caso de neurônios, o tratamento com nicotina, que provocou diminuição do RNAm da ECA somente em WKY, fez com que houvesse maior quantidade de RNAm da ECA em neurônios de SHR após 12, 24 e 48

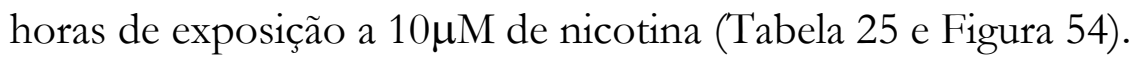


TABELA 25. Variação na expressão do RNAm da enzima conversora de angiotensina (ECA) em cultura de células gliais e neuronais de ratos espontaneamente hipertensos (SHR) e Wistar Kyoto (WKY, normotensos) após tratamento com nicotina (10 $\mu \mathrm{M})$ durante 4, 12, 24 e 48h (curva temporal), ou 1, 10 e $100 \mu \mathrm{M}$ por 24 horas (dose-resposta).

\begin{tabular}{|c|c|c|c|c|c|c|c|c|}
\hline \multirow{4}{*}{$\begin{array}{c}\text { Curva } \\
\text { temporal } \\
\text { controle }\end{array}$} & \multicolumn{8}{|c|}{ Variação na expressão (vezes) } \\
\hline & \multicolumn{2}{|c|}{ Co-cultura - neurônios } & \multicolumn{2}{|c|}{ Co-cultura-glia } & \multicolumn{2}{|c|}{ Hipotálamo - glia } & \multicolumn{2}{|c|}{ Tronco encefálico - glia } \\
\hline & WKY & SHR & WKY & SHR & WKY & SHR & WKY & SHR \\
\hline & $1,000 \pm 0,000$ & $1,026 \pm 0,055$ & $1,000 \pm 0,000$ & $0,850 \pm 0,021$ & $1,000 \pm 0,000$ & $0,687 \pm 0,097 *$ & $1,000 \pm 0,000$ & $1,170 \pm 0,053^{*}$ \\
\hline $4 h$ & $0,715 \pm 0,064$ & $0,932 \pm 0,061$ & $1,094 \pm 0,007$ & $0,727 \pm 0,108^{*}$ & $0,516 \pm 0,026^{\#}$ & $0,679 \pm 0,028$ & $1,273 \pm 0,132$ & $0,869 \pm 0,090$ \\
\hline $12 b$ & $0,622 \pm 0,135^{\#}$ & $1,043 \pm 0,097 *$ & $0,471 \pm 0,008^{\#}$ & $0,454 \pm 0,070^{\#}$ & $0,398 \pm 0,039^{\#}$ & $1,782 \pm 0,125^{\# *}$ & $0,889 \pm 0,132$ & $1,354 \pm 0,205^{*}$ \\
\hline $24 h$ & $0,622 \pm 0,042^{\#}$ & $1,008 \pm 0,106^{*}$ & $0,541 \pm 0,105^{\#}$ & $0,691 \pm 0,072$ & $0,453 \pm 0,149^{\#}$ & $1,705 \pm 0,102^{\# *}$ & $0,956 \pm 0,029$ & $1,515 \pm 0,010^{\# *}$ \\
\hline $48 \mathrm{~h}$ & $0,537 \pm 0,095^{\#}$ & $0,888 \pm 0,047 *$ & $1,190 \pm 0,049$ & $1,023 \pm 0,025$ & $0,419 \pm 0,013^{\#}$ & $1,015 \pm 0,035^{*}$ & $0,690 \pm 0,024^{\#}$ & $2,010 \pm 0,092^{\# *}$ \\
\hline
\end{tabular}

\begin{tabular}{ccccccccc}
\hline Dose-resposta & & & & & & & \\
controle & $1,000 \pm 0,000$ & $1,026 \pm 0,055$ & $1,000 \pm 0,000$ & $0,8499 \pm 0,021$ & $1,000 \pm 0,000$ & $0,687 \pm 0,097 *$ & $1,000 \pm 0,000$ & $1,170 \pm 0,053^{*}$ \\
$1 \mu M$ & $1,036 \pm 0,050$ & $1,150 \pm 0,056$ & $1,537 \pm 0,032^{\#}$ & $1,139 \pm 0,075$ & $0,773 \pm 0,166$ & $0,879 \pm 0,100$ & $1,091 \pm 0,004$ & $1,343 \pm 0,032^{*}$ \\
$10 \mu M$ & $0,622 \pm 0,042^{\#}$ & $1,008 \pm 0,106^{*}$ & $0,541 \pm 0,105$ & $0,691 \pm 0,072$ & $0,453 \pm 0,149^{\#}$ & $1,705 \pm 0,102^{\# *}$ & $0,956 \pm 0,029$ & $1,515 \pm 0,010^{\# *}$ \\
$100 \mu M$ & $1,082 \pm 0,075$ & $1,173 \pm 0,024$ & $1,543 \pm 0,138^{\#}$ & $0,893 \pm 0,034^{*}$ & $0,439 \pm 0,044^{\#}$ & $0,796 \pm 0,118$ & $1,626 \pm 0,012^{\#}$ & $1,937 \pm 0,035^{\# *}$
\end{tabular}

Os valores estão representados como média aritmética $\pm E P M .{ }^{*} p<0,05$ comparado com controle da mesma linhagem, ${ }^{*} p<0,05$ comparado com WKY na mesma situação, segundo a análise de variância (ANOV A) de duas vias seguida do pós-teste de Bonferroni. 
ECA- neurônios - co-cultura

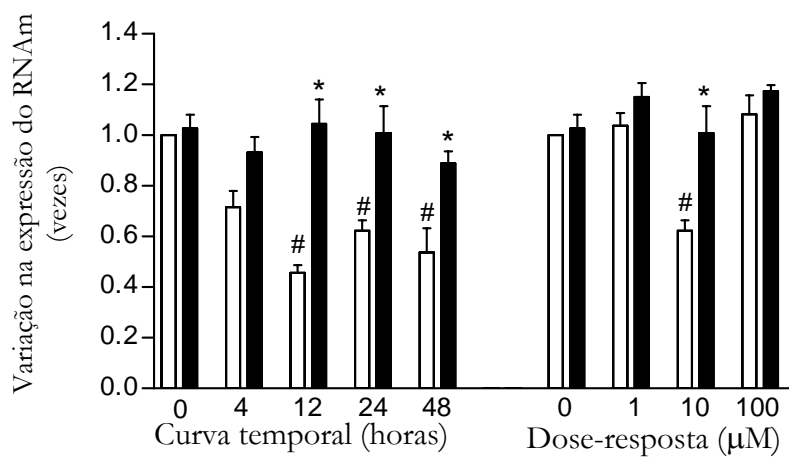

ECA-glia - hipotálamo

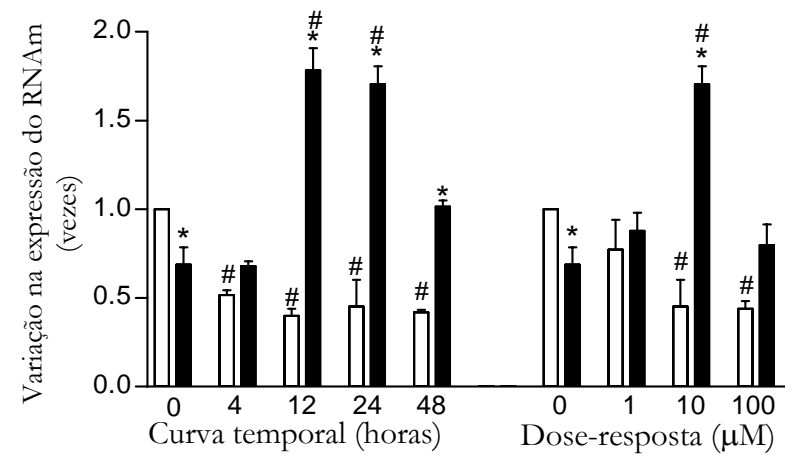

ECA- glia - co-cultura

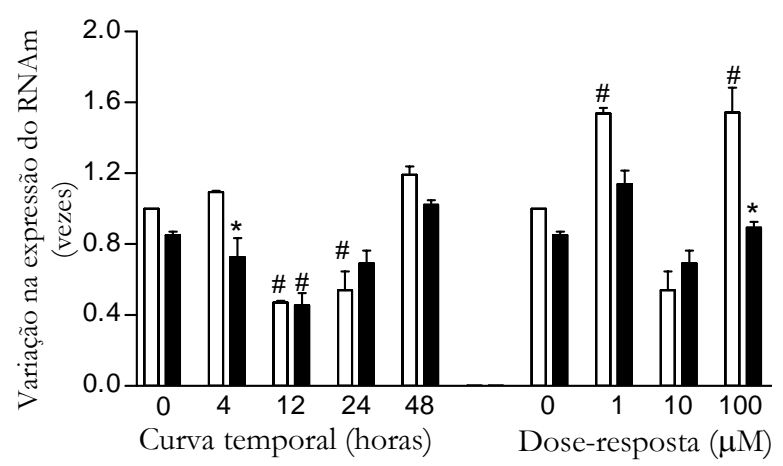

ECA-glia - tronco encefálico

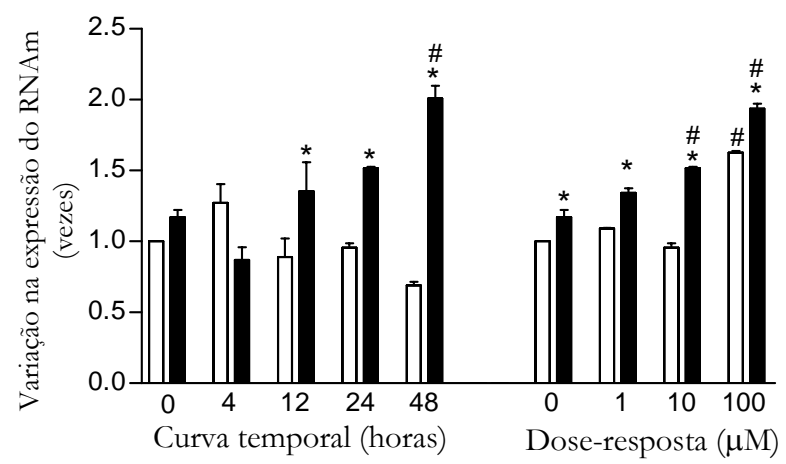

FIGURA 54. Variação na expressão do RNAm da enzima conversora de angiotensina em cultura de células neuronais e gliais do hipotálamo, tronco encefálico ou co-cultura hipotálamo/tronco encefálico de ratos espontaneamente hipertensos (SHR, barras pretas) e Wistar Kyoto (WKY, normotensos, barras brancas) após tratamento com nicotina $(10 \mu \mathrm{M})$ durante 4 , 12, 24 e 48 horas (curva temporal) ou 1, 10 e $100 \mu \mathrm{M}$ por 24 horas (curva doseresposta). Os valores estão representados como média aritmética $\pm E P M .{ }^{*} p<0,05$ comparado com controle da mesma linhagem, ${ }^{*} p<0,05$ comparado com WKY na mesma situação, segundo a análise de variância (ANOVA) de duas vias seguida do pós-teste de Bonferroni. 
A nicotina fez com que a quantidade de RNAm do receptor $\mathrm{AT}_{2}$ de neurônios em co-cultura fosse diminuída tanto em SHR quanto em WKY. No entanto, a ação da droga sobre a linhagem hipertensa teve um espectro maior

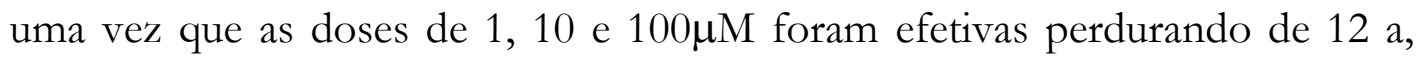
pelo menos, 48 horas. Em neurônios de ratos WKY, a nicotina promoveu diminuição do RNAm da ECA somente em dose pequena $(1 \mu \mathrm{M})$ e com efeito agudo (4 e 12 horas).

Foi observado também que a quantidade de RNAm para o receptor $\mathrm{AT}_{2}$ é cerca de 3 vezes maior em neurônios de SHR que em WKY. Esta diferença se extingue com $100 \mu \mathrm{M}$ de nicotina (Tabela 26 e Figura 55).

TABELA 26. Variação na expressão do RNAm do receptor $\mathrm{AT}_{2}$ de angiotensina em co-cultura de neurônios de ratos espontaneamente hipertensos (SHR) e Wistar Kyoto (WKY, normotensos) após tratamento com nicotina $(10 \mu \mathrm{M})$ durante 4, 12, 24 e 48h (curva temporal), ou 1, 10 e $100 \mu \mathrm{M}$ por 24 horas (dose-resposta).

\begin{tabular}{|c|c|c|}
\hline & \multicolumn{2}{|c|}{ Variação na expressão (vezes) } \\
\hline & \multicolumn{2}{|c|}{ Co-cultura - neurônios } \\
\hline Curva temporal & WKY & SHR \\
\hline controle & $1,000 \pm 0,000$ & $3,215 \pm 0,267^{*}$ \\
\hline $4 h$ & $0,689 \pm 0,063^{\#}$ & $2,214 \pm 0,255^{*}$ \\
\hline $12 b$ & $0,688 \pm 0,059^{\#}$ & $1,886 \pm 0,006^{\#} *$ \\
\hline $24 b$ & $0,912 \pm 0,045$ & $2,197 \pm 0,068^{\# *}$ \\
\hline $48 \mathrm{~h}$ & $1,051 \pm 0,053$ & $2,131 \pm 0,177^{\# *}$ \\
\hline \multicolumn{3}{|l|}{ Dose-resposta } \\
\hline controle & $1,000 \pm 0,000$ & $3,215 \pm 0,267 *$ \\
\hline $1 \mu M$ & $0,771 \pm 0,029^{\#}$ & $2,295 \pm 0,036^{\# *}$ \\
\hline $10 \mu M$ & $0,912 \pm 0,045$ & $2,197 \pm 0,068^{\#} *$ \\
\hline $100 \mu M$ & $1,008 \pm 0,040$ & $1,316 \pm 0,104^{\#}$ \\
\hline
\end{tabular}

Os valores estão representados como média aritmética $\pm E P M . ~{ }^{*} p<0,05$ comparado com controle da mesma linhagem, * ${ }^{*}<0,05$ comparado com WKY na mesma situação, segundo a análise de variância (ANOV A) de duas vias seguida do pós-teste de Bonferroni. 


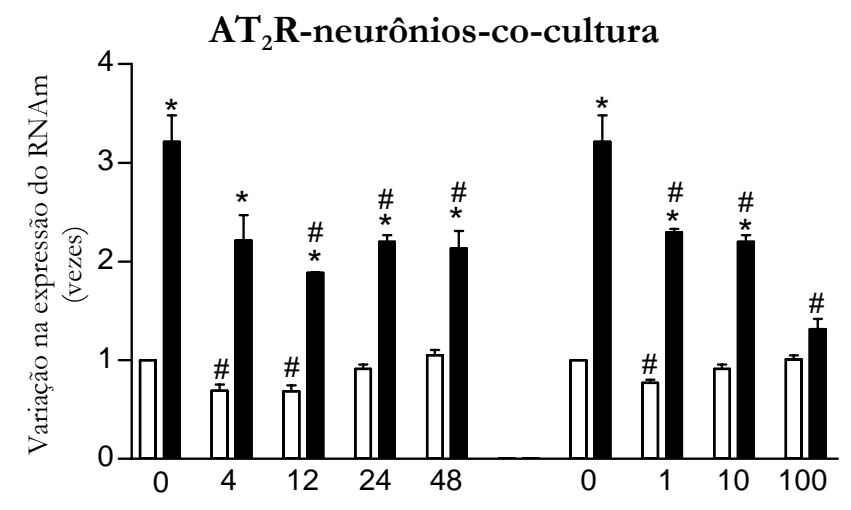

Curva temporal (horas) Dose-resposta $(\mu \mathrm{M})$

FIGURA 55. Variação na expressão do RNAm do receptor $\mathrm{AT}_{2}$ de angiotensina em co-cultura de neurônios de ratos espontaneamente hipertensos (SHR, barras pretas) e Wistar Kyoto (WKY, normotensos, barras brancas) após tratamento com nicotina $(10 \mu \mathrm{M})$ durante 4, 12, 24 e 48 horas (curva temporal) ou 1, 10 e $100 \mu \mathrm{M}$ por 24 horas (curva dose-resposta). Os valores estão representados como média aritmética $\pm E P M .{ }^{\#} p<0,05$ comparado com controle da mesma linhagem, ${ }^{*} p<0,05$ comparado com WKY na mesma situação, segundo a análise de variância (ANOV A) de duas vias seguida do pós-teste de Bonferroni. 
A modulação da nicotina sobre o RNAm do receptor $\mathrm{AT}_{1}$ parece ser dose e tempo dependente. Tratamento com $1 \mu \mathrm{M}$ de nicotina por 24 horas promove diminuição na quantidade de RNAm deste receptor em neurônios de WKY e SHR, no entanto $10 \mu \mathrm{M}$ causam aumento da expressão do RNAm do receptor $\mathrm{AT}_{1}$, mas somente em SHR. A relação temporal também é intrigante: após 4 ou 48 horas de tratamento com $10 \mu \mathrm{M}$ de nicotina há diminuição do RNAm dos receptores $\mathrm{AT}_{1}$ em neurônios tanto de SHR quanto de WKY, mas após 24 horas de exposição à mesma concentração da droga, há aumento na quantidade de RNAm do receptor em SHR, já em WKY não há diferença significativa nos níveis de RNAm do receptor $\mathrm{AT}_{1}$ após 12 ou 24 horas de tratamento com nicotina.

A quantidade de RNAm para o receptor $\mathrm{AT}_{1}$ é mais de duas vezes maior em neurônios de SHR do que a encontrada em WKY. Esta diferença persiste mesmo após o tratamento com 1, 10 ou $100 \mu \mathrm{M}$ de nicotina, só não sendo diferentes os níveis de RNAm deste receptor quando o tratamento com $10 \mu \mathrm{M}$ de nicotina é feito por 48 horas (Tabela 26 e Figura 55).

Em células gliais, o comportamento do RNAm do receptor $\mathrm{AT}_{1}$ é mais consistente e diferente do observado para neurônios. Em cultura do tronco encefálico, observou-se diminuição na quantidade de RNAm do receptor $\mathrm{AT}_{1}$ após tratamento com 1, 10 e $100 \mu \mathrm{M}$ de nicotina para as células de SHR, e somente após $10 \mu \mathrm{M}$ para WKY. A diminuição dos níveis deste RNAm aconteceu logo após 4 horas de tratamento para WKY e 12 horas para SHR permanecendo nesta situação até o final do período analisado.

A modulação da nicotina sobre o RNAm do receptor $\mathrm{AT}_{1}$ foi inversa quando consideradas células gliais do hipotálamo de SHR, pois houve aumento de quase 5 vezes na quantidade do RNAm após 24 horas de tratamento com 
$10 \mu \mathrm{M}$ de nicotina. Em células gliais de hipotálamo de WKY, a nicotina diminuiu os níveis de RNAm do receptor $\mathrm{AT}_{1}$ (Tabela 27 e Figura 56).

Em co-cultura de células gliais, a resposta ao tratamento com nicotina foi uma espécie de somatória dos resultados obtidos na cultura do tronco encefálico e hipotálamo: houve um aumento pequeno, porém significativo, na quantidade de RNAm do receptor $\mathrm{AT}_{1}$ após 1 e $10 \mu \mathrm{M}$ de nicotina e com 12 e 24 horas de tratamento.

Foram encontrados maiores níveis de RNAm do receptor $\mathrm{AT}_{1}$ em cultura de células gliais do tronco encefálico de SHR tanto em situação controle quanto após tratamento com nicotina. Em cultura de células gliais do hipotálamo e em co-cultura, a quantidade de RNAm do receptor $\mathrm{AT}_{1}$ elevou-se em SHR comparados com WKY somente com o tratamento com nicotina (Tabela 27 e Figura 56). 
TABELA 27. Variação na expressão do RNAm do receptor $\mathrm{AT}_{1}$ de angiotensina em cultura de células gliais e neuronais de ratos espontaneamente hipertensos (SHR) e Wistar Kyoto (WKY, normotensos) após tratamento com nicotina (10 $\mu \mathrm{M})$ durante 4, 12, 24 e 48h (curva temporal), ou 1, 10 e $100 \mu \mathrm{M}$ por 24 horas (dose-resposta).

\begin{tabular}{|c|c|c|c|c|c|c|c|c|}
\hline \multirow[b]{3}{*}{ Curva temporal } & \multicolumn{8}{|c|}{ Variação na expressão (vezes) } \\
\hline & \multicolumn{2}{|c|}{ Co-cultura - neurônios } & \multicolumn{2}{|c|}{ Co-cultura-glia } & \multicolumn{2}{|c|}{ Hipotálamo - glia } & \multicolumn{2}{|c|}{ Tronco encefálico - glia } \\
\hline & WKY & SHR & WKY & SHR & WKY & SHR & WKY & SHR \\
\hline controle & $1,000 \pm 0,000$ & $2,298 \pm 0,032^{*}$ & $1,000 \pm 0,000$ & $1,154 \pm 0,052$ & $1,000 \pm 0,000$ & $1,044 \pm 0,058$ & $1,000 \pm 0,000$ & $4,014 \pm 0,014^{*}$ \\
\hline $4 h$ & $0,549 \pm 0,062^{\#}$ & $0,865 \pm 0,063^{\# *}$ & $0,478 \pm 0,008^{\#}$ & $1,624 \pm 0,190 *$ & $0,281 \pm 0,031^{\#}$ & $1,949 \pm 0,121 *$ & $0,378 \pm 0,001^{\#}$ & $3,760 \pm 0,130^{*}$ \\
\hline $12 b$ & $0,859 \pm 0,101$ & $2,278 \pm 0,073^{*}$ & $0,551 \pm 0,095^{\#}$ & $1,994 \pm 0,119^{\# *}$ & $0,156 \pm 0,007^{\#}$ & $2,852 \pm 0,036^{*}$ & $0,277 \pm 0,010^{\#}$ & $2,635 \pm 0,289^{\# *}$ \\
\hline $24 b$ & $1,113 \pm 0,081$ & $2,910 \pm 0,053^{*}$ & $0,688 \pm 0,047$ & $1,981 \pm 0,116^{\# *}$ & $0,526 \pm 0,040^{\#}$ & $4,960 \pm 0,673^{\# *}$ & $0,225 \pm 0,041^{\#}$ & $2,149 \pm 0,062^{\#_{*}}$ \\
\hline $48 \mathrm{~b}$ & $0,484 \pm 0,049^{\#}$ & $0,465 \pm 0,033^{\#}$ & $0,999 \pm 0,129$ & $1,795 \pm 0,108^{*}$ & $0,853 \pm 0,095$ & $1,362 \pm 0,320$ & $0,496 \pm 0,128^{\#}$ & $2,696 \pm 0,075^{\# *}$ \\
\hline \multicolumn{9}{|l|}{ Dose-resposta } \\
\hline controle & $1,000 \pm 0,000$ & $2,298 \pm 0,0318 *$ & $1,000 \pm 0,000$ & $1,154 \pm 0,052$ & $1,000 \pm 0,000$ & $1,044 \pm 0,058$ & $1,000 \pm 0,000$ & $4,014 \pm 0,014 *$ \\
\hline $1 \mu M$ & $0,471 \pm 0,024^{\#}$ & $1,730 \pm 0,048^{\#} *$ & $0,955 \pm 0,073$ & $1,966 \pm 0,034^{\# *}$ & $0,150 \pm 0,042^{\#}$ & $1,656 \pm 0,161 *$ & $0,974 \pm 0,026$ & $1,129 \pm 0,019^{\#} *$ \\
\hline $10 \mu M$ & $1,113 \pm 0,081$ & $2,910 \pm 0,054^{\#} *$ & $0,688 \pm 0,047^{\#}$ & $1,981 \pm 0,116^{\#} *$ & $0,526 \pm 0,040^{\#}$ & $4,960 \pm 0,673^{\#} *$ & $0,225 \pm 0,0408^{\#}$ & $2,149 \pm 0,062^{\#} *$ \\
\hline $100 \mu M$ & $0,963 \pm 0,023$ & $2,379 \pm 0,066^{*}$ & $0,725 \pm 0,012^{\#}$ & $0,812 \pm 0,059$ & $0,597 \pm 0,086^{\#}$ & $2,481 \pm 0,232^{*}$ & $0,807 \pm 0,133$ & $2,936 \pm 0,127^{\#} *$ \\
\hline
\end{tabular}

Os valores estão representados como média aritmética $\pm E P M$. ${ }^{*} p<0,05$ comparado com controle da mesma linhagem, ${ }^{*} p<0,05$ comparado com WKY na mesma situação, segundo a análise de variância (ANOVA) de duas vias seguida do pós-teste de Bonferroni. 
$\mathrm{AT}_{1} \mathbf{R}$ - neurônios - co-cultura $\mathrm{AT}_{1} \mathbf{R}$ - glia - co-cultura
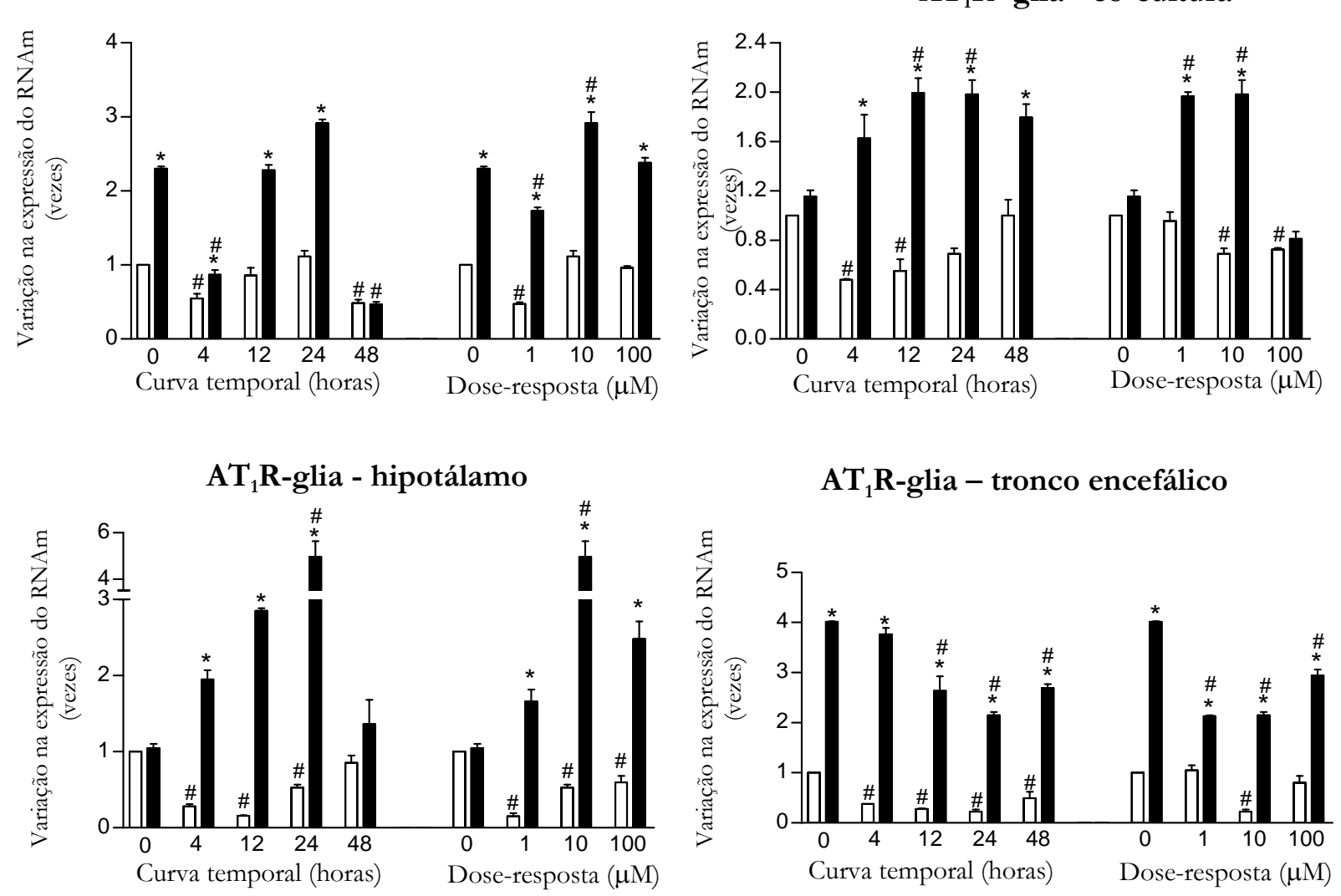

FIGURA 56. Variação na expressão do RNAm do receptor $\mathrm{AT}_{1}$ de angiotensina em cultura de células neuronais e gliais do hipotálamo, tronco encefálico ou co-cultura hipotálamo/tronco encefálico de ratos espontaneamente hipertensos (SHR, barras pretas) e Wistar Kyoto (WKY, normotensos, barras brancas) após tratamento com nicotina $(10 \mu \mathrm{M})$ durante 4 , 12, 24 e 48 horas (curva temporal) ou 1, 10 e $100 \mu \mathrm{M}$ por 24 horas (curva doseresposta). Os valores estão representados como média aritmética $\pm E P M .{ }^{*} p<0,05$ comparado com controle da mesma linhagem, ${ }^{*} p<0,05$ comparado com WKY na mesma situação, segundo a análise de variância (ANOVA) de duas vias seguida do pós-teste de Bonferroni. 


\subsection{Quantificação de proteínas do sistema angiotensinérgico através de Western Blot.}

O tratamento com nicotina diminuiu os níveis do receptor $\mathrm{AT}_{1} \mathrm{em}$ cultura de células gliais do tronco encefálico tanto de SHR quanto de ratos WKY. As doses de 1 e $10 \mu \mathrm{M}$, mas não $100 \mu \mathrm{M}$, foram efetivas na resposta inibitória da nicotina sobre estes receptores na glia. O efeito iniciou-se após 4 ou 12 horas, para SHR e WKY, respectivamente, e permaneceu até o final do tratamento (48 horas) (Tabela 28 e Figura 57). Um resultado bastante semelhante foi observado para células gliais em co-cultura hipotálamo/tronco encefálico (Tabela 28 e Figura 57). A quantidade de receptores $\mathrm{AT}_{1}$ encontrada em SHR foi significativamente maior que em WKY considerando cultura de células gliais somente de tronco encefálico ou co-cultura.

Em cultura de células gliais do hipotálamo, a nicotina promoveu diminuição dos receptores $\mathrm{AT}_{1}$ somente em $\mathrm{WKY}$ após 4 horas de tratamento com $10 \mu \mathrm{M}$ da droga, já em SHR a nicotina aumentou a expressão destes receptores após 12 horas com $10 \mu \mathrm{M}$ ou 24 horas com $100 \mu \mathrm{M}$. Não foi observada diferença significativa na quantidade dos receptores $\mathrm{AT}_{1}$ em células gliais do hipotálamo entre as linhagens de rato (Tabela 28 e Figura 57).

Os neurônios de SHR apresentaram menor quantidade de receptores $\mathrm{AT}_{1}$ se comparados com $\mathrm{WKY}$, salvo após 48 horas de tratamento com $10 \mu \mathrm{M}$ de nicotina quando houve aumento da expressão desses receptores tornandoos mais abundantes em SHR do que em WKY. O tratamento com nicotina só alterou, para cima, os níveis do receptor em SHR após 48 horas de exposição a $10 \mu \mathrm{M}$ da droga, enquanto $100 \mu \mathrm{M}$ de nicotina diminuiu a expressão do receptor em SHR. No entanto, em WKY, a nicotina aumentou a expressão dos receptores $\mathrm{AT}_{1}$ após tratamento com 1, 10 ou $100 \mu \mathrm{M}$ durante 24 horas, ou $10 \mu \mathrm{M}$ por 12 horas (Tabela 28 e Figura 58). 
$\mathrm{O}$ western blot para os receptores $\mathrm{AT}_{2}$ foi feito apenas para neurônios uma vez que não há quantidade significativa destes receptores em células gliais. Observaram-se duas bandas distintas de proteínas com peso molecular de aproximadamente 55 e $50 \mathrm{kDa}$. As bandas foram quantificadas separadamente, mas o resultado do tratamento com nicotina foi bastante semelhante entre as proteínas marcadas. Células neuronais em co-cultura apresentaram aumento na quantidade de receptores $\mathrm{AT}_{2}$ após 48 horas de exposição a $10 \mu \mathrm{M}$ de nicotina e diminuição após 24 horas com $100 \mu \mathrm{M}$ da droga (Tabela 29 e Figura 59). Os neurônios de ratos WKY tiveram a quantidade desses receptores aumentada após incubação com 1, 10 e $100 \mu \mathrm{M}$ de nicotina por 24 horas e com $10 \mu \mathrm{M}$ por 12 horas. O tratamento com alcalóide fez com que a quantidade dos receptores $\mathrm{AT}_{2}$ em SHR ficasse menor que em WKY (Tabela 29 e Figura 59).

Por último, analisou-se a enzima conversora de angiotensina 2 (ECA2) que foi regulada negativamente pela nicotina em neurônios de co-cultura tronco encefálico/hipotálamo tanto de SHR quanto de ratos WKY. No entanto, a magnitude da resposta foi bem maior em neurônios da linhagem hipertensa (Tabela 30 e Figura 60). A diminuição da proteína foi verificada após administração de 1, 10 e $100 \mu \mathrm{M}$ de nicotina em ratos SHR, ao passo que somente 1 e $100 \mu \mathrm{M}$ da droga foram capazes de diminuir a quantidade de ECA2 em WKY (Tabela 30 e Figura 60). A curva temporal revelou que somente após 48 horas de exposição a $10 \mu \mathrm{M}$ de nicotina, os neurônios de WKY apresentaram diminuição da ECA2, ao passo que neurônios de ratos SHR mostraram menor quantidade de ECA2 após 4, 12 e 24 horas de exposição a $10 \mu \mathrm{M}$ de nicotina, voltando ao estado basal após 48 horas de tratamento.

O tratamento com nicotina também diminuiu a quantidade de ECA2 em co-cultura de células gliais das duas linhagens, mas, como em neurônios, os ratos hipertensos pareceram mais sensíveis à ação da droga considerando a 
intensidade da resposta. No estudo dose-resposta, as três doses analisadas promoveram diminuição dos níveis de ECA2 em WKY e SHR (Tabela 30 e Figura 60). A análise temporal mostrou que a diminuição dos níveis de ECA2 acontece a partir de 4 ou 12 horas de tratamento com $10 \mu \mathrm{M}$ de nicotina, para SHR e WKY, respectivamente, permanecendo nesta situação até o final do experimento.

Interessantemente, os níveis de ECA2 em neurônios e células gliais em co-cultura são menores em SHR que em WKY (Tabela 30 e Figura 60).

A nicotina também diminuiu os níveis de ECA2 em células gliais do tronco encefálico. As três doses utilizadas no experimento de dose-resposta foram efetivas na diminuição da ECA2 em SHR, ratos WKY apresentaram diminuição da ECA2 apenas após $10 \mu \mathrm{M}$ de nicotina. A resposta inibitória da nicotina sobre os níveis de ECA2 apareceu após 12 horas de incubação com $10 \mu \mathrm{M}$ de nicotina e permaneceu até 24 ou 48 horas de tratamento, para ratos WKY e SHR, respectivamente (Tabela 30 e Figura 61). Não foi observada diferença na quantidade de ECA2 entre as linhagens no estado basal. 
TABELA 28. Densidade óptica relativa em unidade arbitrária (u.a.) do receptor $\mathrm{AT}_{1}$ de angiotensina em cultura de células gliais e neuronais de ratos espontaneamente hipertensos (SHR) e Wistar Kyoto (WKY, normotensos) após tratamento com nicotina (10 $\mu \mathrm{M})$ durante 4, 12, 24 e 48h (curva temporal), ou 1, 10 e 100 $\mu \mathrm{M}$ por 24 horas (dose-resposta).

\begin{tabular}{|c|c|c|c|c|c|c|c|c|}
\hline \multirow[b]{3}{*}{ Curva temporal } & \multicolumn{8}{|c|}{ Densidade óptica relativa (u.a.) $-\mathrm{AT}_{1} \mathrm{R} /$ alfa-tubulina } \\
\hline & \multicolumn{2}{|c|}{ Co-cultura - neurônios } & \multicolumn{2}{|c|}{ Co-cultura-glia } & \multicolumn{2}{|c|}{ Hipotálamo - glia } & \multicolumn{2}{|c|}{ Tronco encefálico - glia } \\
\hline & WKY & SHR & WKY & SHR & WKY & SHR & WKY & SHR \\
\hline controle & $19,78 \pm 1,03$ & $11,52 \pm 1,19 *$ & $11,02 \pm 0,78$ & $17,91 \pm 0,58^{*}$ & $14,99 \pm 0,81$ & $14,93 \pm 0,40$ & $37,58 \pm 1,77$ & $64,18 \pm 0,85^{*}$ \\
\hline $4 h$ & $17,07 \pm 1,92$ & $7,96 \pm 0,86^{*}$ & $7,63 \pm 0,97^{\#}$ & $5,81 \pm 0,17^{\#}$ & $9,29 \pm 0,31^{\#}$ & $13,46 \pm 1,52^{*}$ & $41,33 \pm 0,73$ & $44,11 \pm 0,87^{\#}$ \\
\hline $12 b$ & $29,58 \pm 1,56^{\#}$ & $7,73 \pm 0,71 *$ & $4,28 \pm 0,093^{\#}$ & $6,40 \pm 0,34^{\#}$ & $12,25 \pm 1,12$ & $21,65 \pm 1,09 *$ & $27,10 \pm 1,73^{\#}$ & $51,29 \pm 0,56^{\# *}$ \\
\hline $24 b$ & $33,68 \pm 2,20^{\#}$ & $9,93 \pm 0,90 *$ & $3,81 \pm 0,18^{\#}$ & $7,77 \pm 0,53^{\#} *$ & $16,24 \pm 0,74$ & $14,89 \pm 0,41$ & $25,89 \pm 1,09^{\#}$ & $44,09 \pm 1,21^{\# *}$ \\
\hline $48 h$ & $11,83 \pm 1,50$ & $21,07 \pm 0,79^{\# *}$ & $6,59 \pm 0,21^{\#}$ & $9,16 \pm 0,37^{\# *}$ & $11,89 \pm 0,91$ & $13,22 \pm 0,32$ & $17,70 \pm 1,10^{\#}$ & $41,09 \pm 1,44^{\# *}$ \\
\hline
\end{tabular}

\begin{tabular}{ccccccccc}
\hline $\begin{array}{c}\text { Dose-resposta } \\
\text { controle }\end{array}$ & $19,78 \pm 1,03$ & $11,52 \pm 1,19^{*}$ & $11,17 \pm 0,93$ & $17,78 \pm 0,71^{*}$ & $14,64 \pm 0,46$ & $13,80 \pm 0,73$ & $37,58 \pm 1,77$ & $64,18 \pm 0,85^{*}$ \\
$1 \mu M$ & $66,73 \pm 0,74^{\#}$ & $9,22 \pm 0,40^{*}$ & $5,47 \pm 0,43^{\#}$ & $9,21 \pm 0,65^{\# *}$ & $14,22 \pm 1,18$ & $17,40 \pm 0,84$ & $23,81 \pm 0,85^{\#}$ & $43,26 \pm 1,11^{\# *}$ \\
$10 \mu M$ & $33,68 \pm 2,20^{\#}$ & $9,93 \pm 0,90^{*}$ & $3,75 \pm 0,13^{\#}$ & $7,11 \pm 0,12^{\# *}$ & $15,69 \pm 0,19$ & $15,74 \pm 1,25$ & $25,89 \pm 1,09^{\#}$ & $44,09 \pm 1,21^{\# *}$ \\
$100 \mu M$ & $41,19 \pm 1,80^{\#}$ & $7,59 \pm 0,27^{\# *}$ & $7,86 \pm 0,57$ & $12,06 \pm 0,86^{\# *}$ & $14,39 \pm 1,09$ & $26,53 \pm 1,39^{\# *}$ & $33,76 \pm 2,78$ & $59,19 \pm 1,13 *$
\end{tabular}

Os valores estão representados como média aritmética $\pm E P M .{ }^{*} p<0,05$ comparado com controle da mesma linhagem, ${ }^{*} p<0,05$ comparado com WKY na mesma situação, segundo a análise de variância (ANOVA) de duas vias seguida do pós-teste de Bonferroni. 

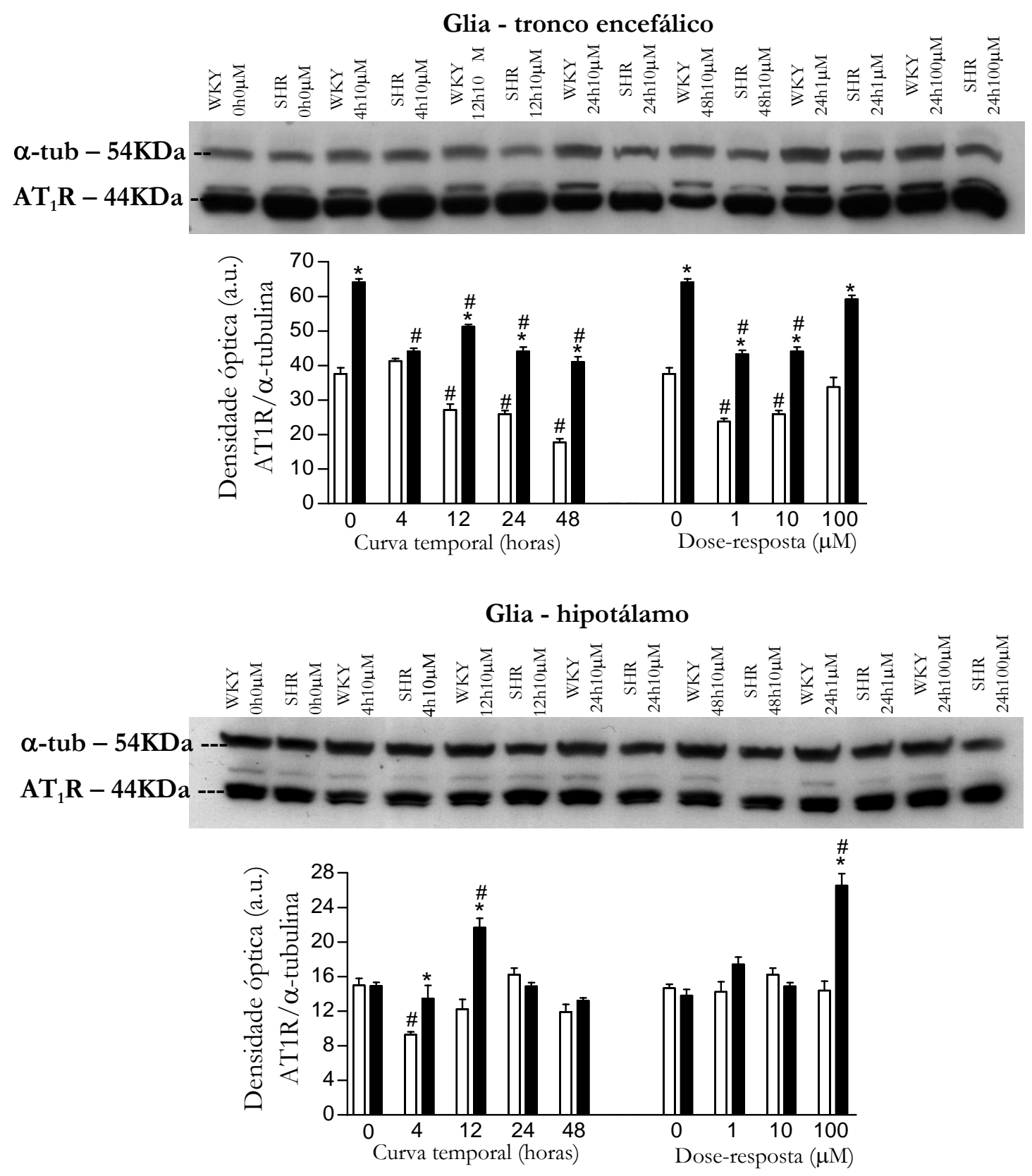

FIGURA 57. Densidade óptica relativa em unidades arbitrárias (u.a.) da marcação referente ao receptor $\mathrm{AT}_{1}$ de angiotensina em cultura de células gliais do tronco encefálico ou hipotálamo de ratos espontaneamente hipertensos (SHR, barras pretas) e Wistar Kyoto (WKY, normotensos, barras brancas) após tratamento com nicotina $(10 \mu \mathrm{M})$ durante $4,12,24$ e 48 horas (curva temporal) ou 1, 10 e $100 \mu \mathrm{M}$ por 24 horas (curva dose-resposta). Os valores foram normalizados dividindo-se o valor referente ao receptor $A T_{1}$ pelo valor da alfa-tubulina e estão representados como média aritmética $\pm E P M .{ }^{\#} p<0,05$ comparado com controle da mesma linhagem, ${ }^{*} p<0,05$ comparado com WKY na mesma situacão, segundo a análise de variancia (ANOVA) de duas vias seguida do pós-teste de Bonferroni. 

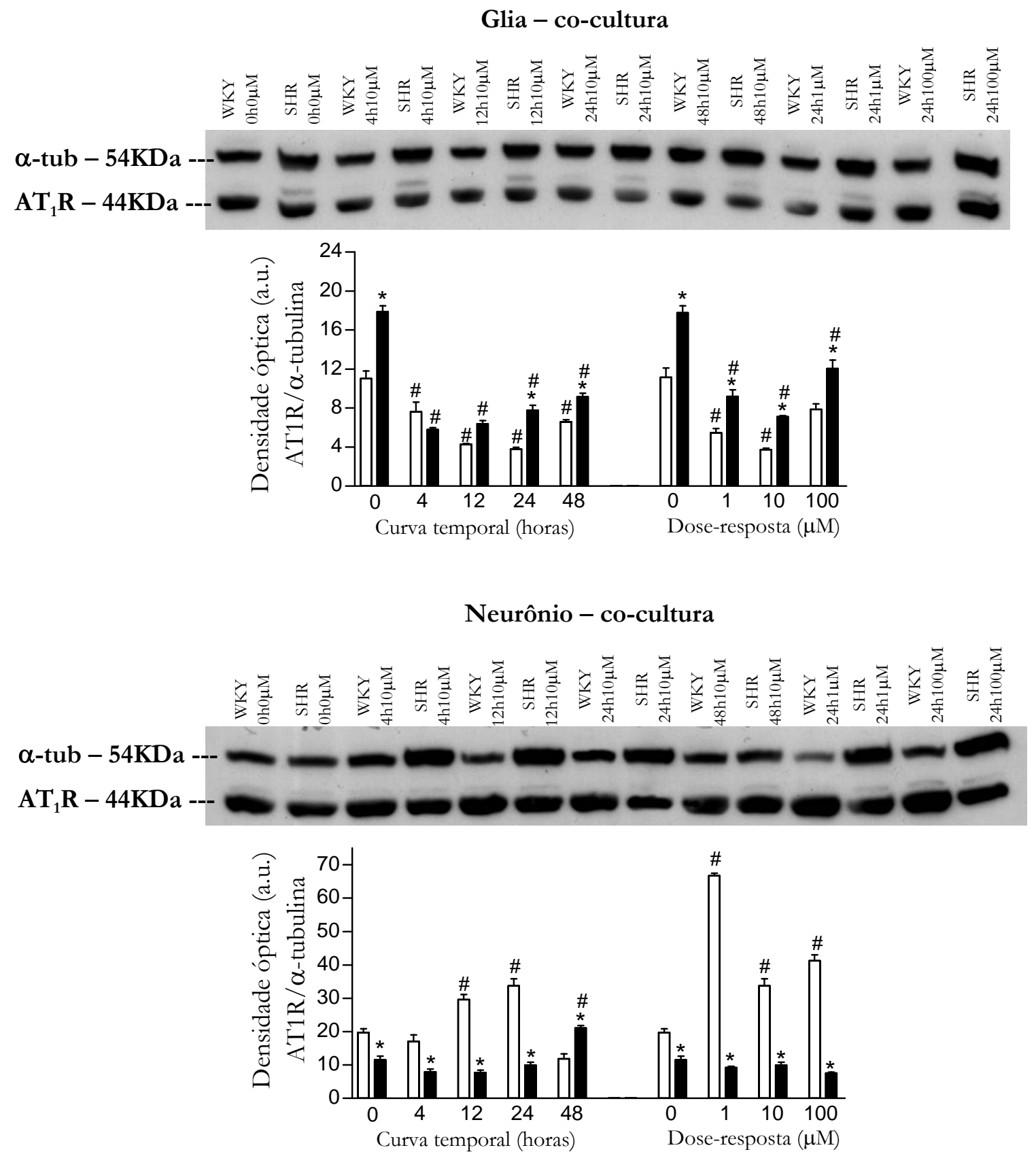

FIGURA 58. Densidade óptica relativa em unidades arbitrárias (u.a.) da marcação referente ao receptor $\mathrm{AT}_{1}$ de angiotensina em co-cultura tronco encefálico/hipotálamo de células gliais ou neurônios de ratos espontaneamente hipertensos (SHR, barras pretas) e Wistar Kyoto (WKY, normotensos, barras brancas) após tratamento com nicotina $(10 \mu \mathrm{M})$ durante 4, 12, 24 e 48 horas (curva temporal) ou 1, 10 e $100 \mu \mathrm{M}$ por 24 horas (curva dose-resposta). Os valores foram normalizados dividindo-se o valor referente ao receptor $A T_{1}$ pelo valor da alfatubulina e estão representados como média aritmética $\pm E P M .{ }^{*} p<0,05$ comparado com controle da mesma linhagem, ${ }^{*} p<0,05$ comparado com WKY na mesma situação, segundo a análise de variância (ANOVA) de duas vias seguida do pós-teste de Bonferroni. 


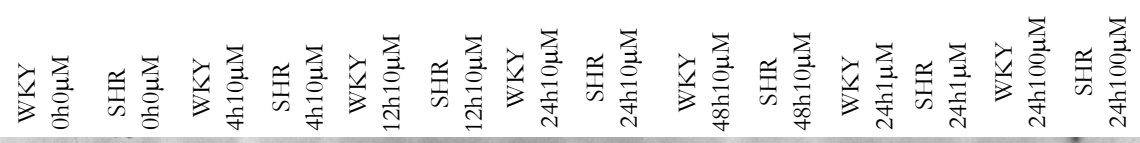

$\mathrm{AT}_{2} \mathrm{R}-55 \mathrm{KDa}$

$\mathrm{AT}_{2} \mathrm{R}-50 \mathrm{KDa}$

$55 \mathrm{kDa}$
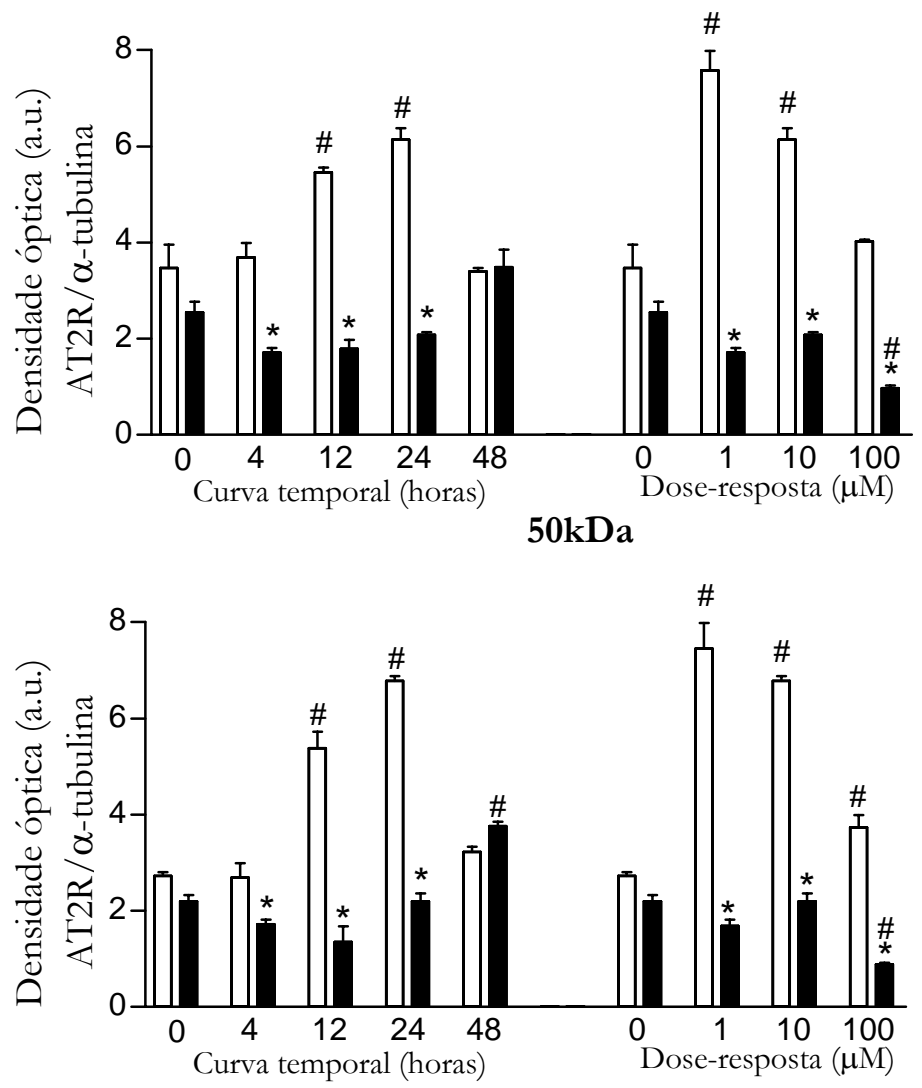

FIGURA 59. Densidade óptica relativa em unidade arbitrária (u.a.) das bandas relativas ao receptor $\mathrm{AT}_{2}$ de angiotensina em co-cultura tronco encefálico/hipotálamo de neurônios de ratos espontaneamente hipertensos (SHR, barras pretas) e Wistar Kyoto (WKY, normotensos, barras brancas) após tratamento com nicotina $(10 \mu \mathrm{M})$ durante 4, 12, 24 e 48 horas (curva temporal) ou 1, 10 e $100 \mu \mathrm{M}$ por 24 horas (curva dose-resposta). Os valores foram normalizados dividindo-se o valor referente ao receptor $A T_{1}$ pelo valor da alfa-tubulina $e$ estão representados como média aritmética $\pm E P M .{ }^{*} p<0,05$ comparado com controle da mesma linhagem, ${ }^{*} p<0,05$ comparado com WKY na mesma situação, segundo a análise de variância (ANOV A) de duas vias seguida do pós-teste de Bonferroni. 
Já as células gliais controle do hipotálamo de SHR mostram-se com menor quantidade de ECA2 em todas as etapas do tratamento. A nicotina diminuiu os níveis de ECA2 com 1 e $10 \mu \mathrm{M}$ por 24 e 48 horas em WKY, ratos SHR apresentaram diminuição da ECA2 após 24 e 48 horas com nicotina a $10 \mu \mathrm{M}$ (Tabela 30 e Figura 61).

A análise estatística através de ANOVA de duas vias permitiu verificar que a resposta ao tratamento com nicotina é influenciada pela linhagem, tempo de exposição e concentração da droga. 
TABELA 30. Densidade óptica relativa em unidade arbitrária (u.a.) da enzima conversora de angiotensina 2 (ECA2) em cultura de células gliais e neuronais de ratos espontaneamente hipertensos (SHR) e Wistar Kyoto (WKY, normotensos) após tratamento com

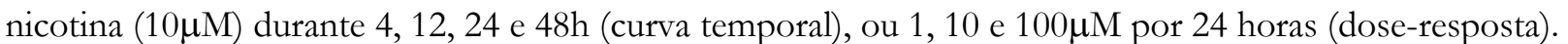

\begin{tabular}{|c|c|c|c|c|c|c|c|c|}
\hline \multirow[b]{3}{*}{ Curva temporal } & \multicolumn{8}{|c|}{ Densidade óptica relativa (u.a.) - ECA2/alfa-tubulina } \\
\hline & \multicolumn{2}{|c|}{ Co-cultura - neurônios } & \multicolumn{2}{|c|}{ Co-cultura-glia } & \multicolumn{2}{|c|}{ Hipotálamo - glia } & \multicolumn{2}{|c|}{ Tronco encefálico - glia } \\
\hline & WKY & SHR & WKY & SHR & WKY & SHR & WKY & SHR \\
\hline controle & $17,780 \pm 1,027$ & $10,770 \pm 0,436^{*}$ & $9,738 \pm 0,364$ & $8,180 \pm 0,114$ & $17,550 \pm 1,255$ & $8,649 \pm 0,318^{*}$ & $9,457 \pm 0,350$ & $10,730 \pm 0,600$ \\
\hline $4 b$ & $20,630 \pm 0,666$ & $3,779 \pm 0,599 * \#$ & $8,445 \pm 0,151$ & $4,187 \pm 0,793^{\# *}$ & $16,180 \pm 0,417$ & $8,173 \pm 0,193^{*}$ & $9,351 \pm 0,245$ & $8,447 \pm 0,533$ \\
\hline $12 b$ & $20,920 \pm 0,832$ & $4,617 \pm 0,302 *^{\#}$ & $4,183 \pm 0,186^{\#}$ & $2,433 \pm 0,302^{\# *}$ & $16,690 \pm 0,320$ & $7,259 \pm 0,524^{*}$ & $6,222 \pm 0,147^{\#}$ & $5,076 \pm 0,659^{\#}$ \\
\hline $24 h$ & $14,900 \pm 1,085$ & $4,658 \pm 0,157^{* \#}$ & $6,447 \pm 0,434^{\#}$ & $2,836 \pm 0,150^{\#} *$ & $12,430 \pm 0,448^{\#}$ & $5,443 \pm 0,142^{\#} *$ & $7,637 \pm 0,348^{\#}$ & $4,901 \pm 0,400^{\#} *$ \\
\hline \multicolumn{9}{|l|}{ Dose-resposta } \\
\hline controle & $17,780 \pm 1,027$ & $10,770 \pm 0,436 *$ & $9,738 \pm 0,364$ & $8,180 \pm 0,114 *$ & $17,550 \pm 1,255$ & $8,649 \pm 0,318^{*}$ & $9,457 \pm 0,350$ & $10,730 \pm 0,600$ \\
\hline $1 \mu M$ & $11,120 \pm 0,841^{\#}$ & $6,444 \pm 0,064^{\# *}$ & $7,258 \pm 0,218^{\#}$ & $3,317 \pm 0,234^{\# *}$ & $11,540 \pm 0,500^{\#}$ & $8,351 \pm 0,200 *$ & $10,260 \pm 0,300$ & $6,329 \pm 0,050^{\# *}$ \\
\hline $10 \mu M$ & $14,900 \pm 1,085$ & $4,658 \pm 0,157^{\#} *$ & $6,447 \pm 0,434^{\#}$ & $2,836 \pm 0,150^{\#} *$ & $12,430 \pm 0,448^{\#}$ & $5,443 \pm 0,142^{\#} *$ & $7,637 \pm 0,348^{\#}$ & $4,901 \pm 0,400^{\#} *$ \\
\hline
\end{tabular}

Os valores estão representados como média aritmética $\pm E P M .{ }^{*} p<0,05$ comparado com controle da mesma linhagem, ${ }^{*} p<0,05$. 

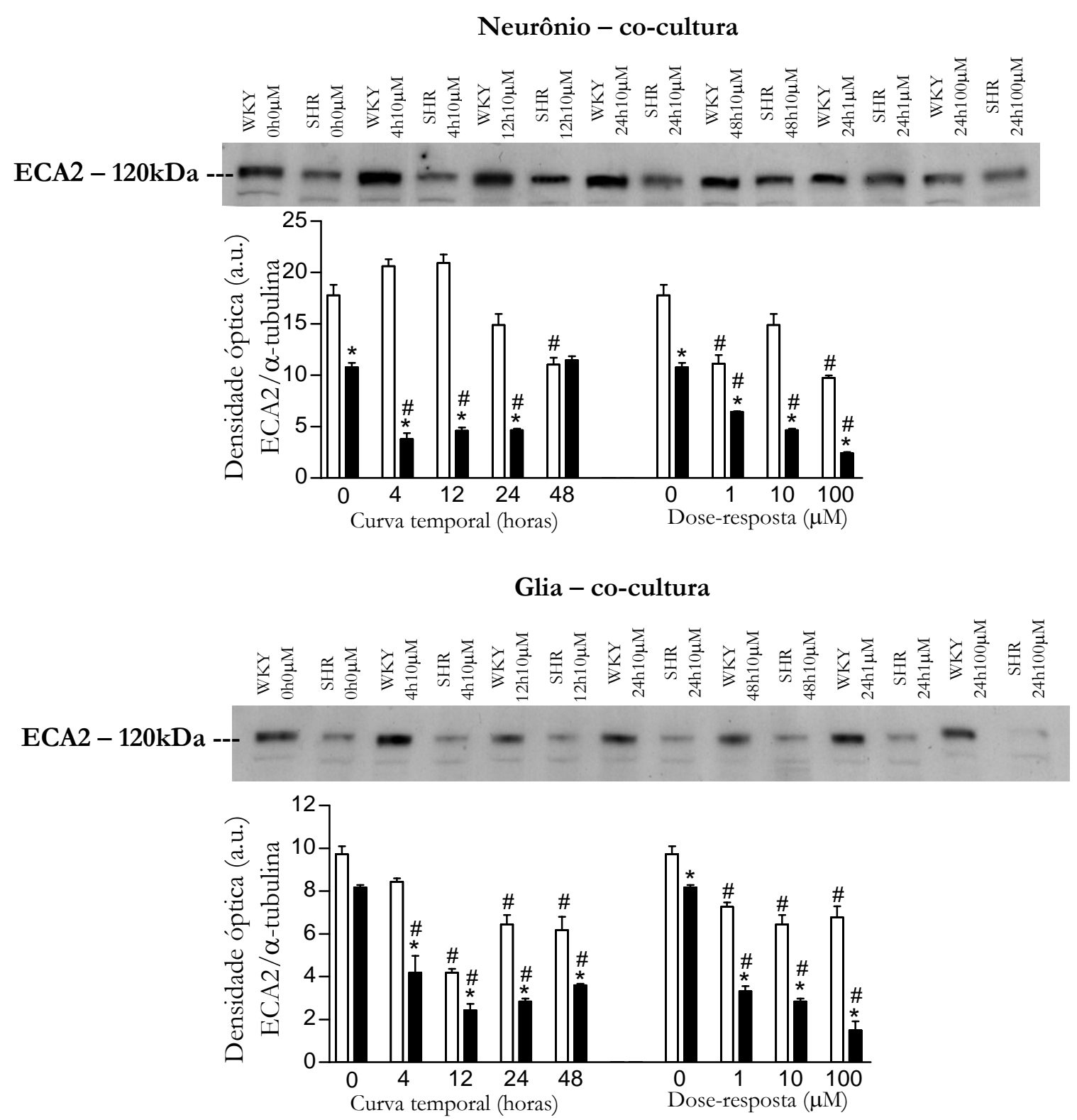

FIGURA 60. Densidade óptica relativa em unidades arbitrárias (u.a.) da marcação referente à enzima conversora de angiotensina 2 (ECA2) em cocultura hipotálamo/tronco encefálico de neurônios ou células gliais de ratos espontaneamente hipertensos (SHR, barras pretas) e Wistar Kyoto (WKY, normotensos, barras brancas) após tratamento com nicotina $(10 \mu \mathrm{M})$ durante 4 , 12, 24 e 48 horas (curva temporal) ou 1, 10 e $100 \mu \mathrm{M}$ por 24 horas (curva doseresposta). Os valores foram normalizados dividindo-se o valor referente ao receptor $A T_{1}$ pelo valor da alfa-tubulina e estão representados como média aritmética $\pm E P M .{ }^{*} p<0,05$ comparado com controle da mesma linhagem, ${ }^{*} p<0,05$ comparado com WKY na mesma situação, segundo a análise de variância ( $A N O V A$ ) de duas vias seguida do pós-teste de Bonferroni. 


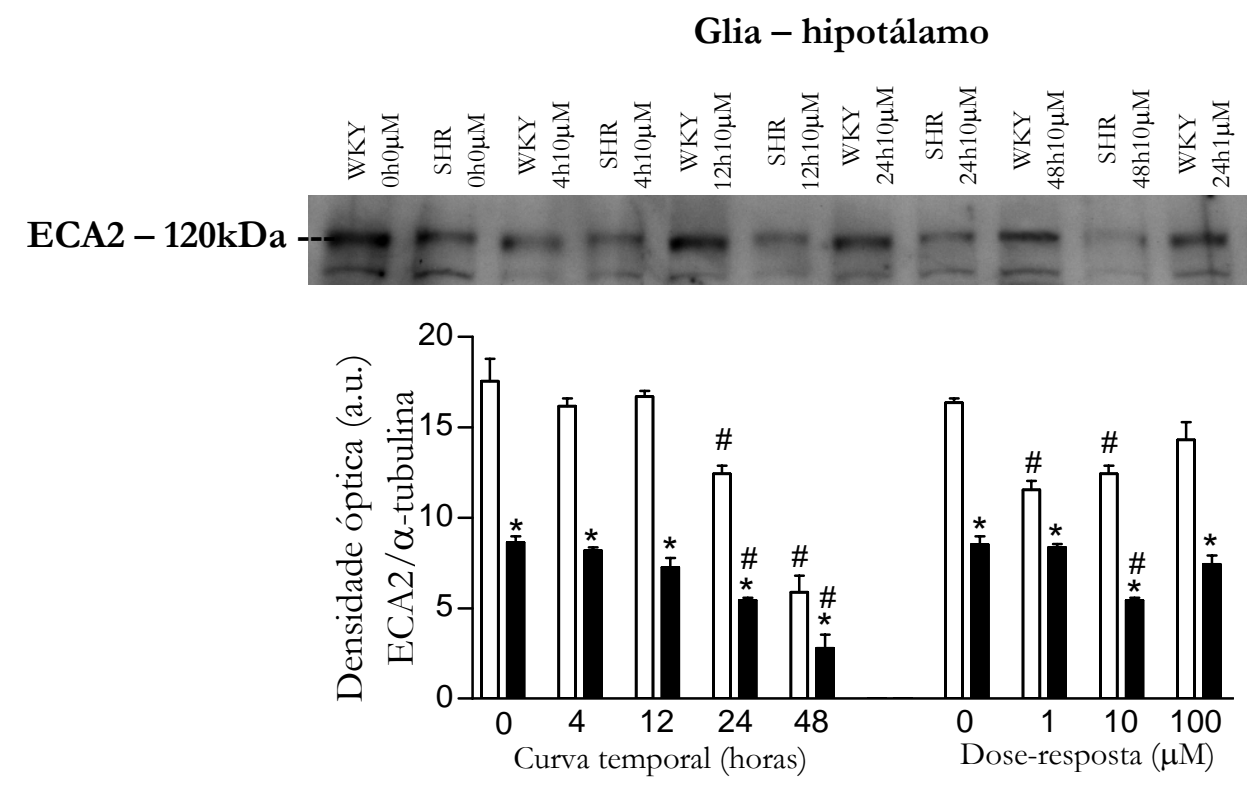

$$
\begin{aligned}
& \text { Glia - tronco encefálico }
\end{aligned}
$$

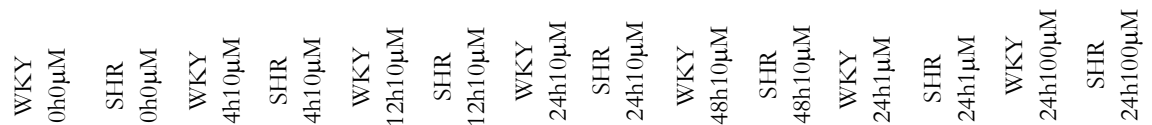

ECA2 - 120kDa -

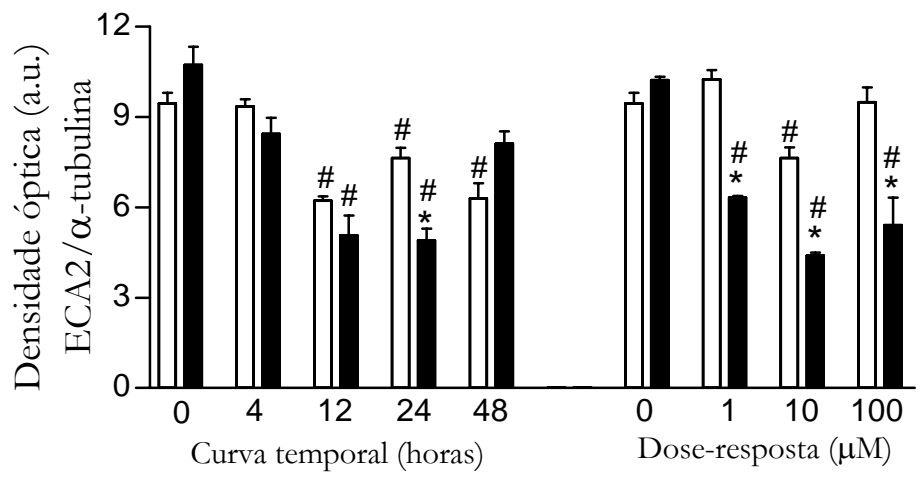

FIGURA 61. Densidade óptica relativa em unidades arbitrárias (u.a.) da marcação referente à enzima conversora de angiotensina 2 (ECA2) em cultura de células gliais do hipotálamo ou tronco encefálico de ratos espontaneamente hipertensos (SHR, barras pretas) e Wistar Kyoto (WKY, normotensos, barras brancas) após tratamento com nicotina $(10 \mu \mathrm{M})$ durante 4, 12, 24 e 48 horas (curva temporal) ou 1, 10 e $100 \mu \mathrm{M}$ por 24 horas (curva dose-resposta). Os valores foram normalizados dividindo-se o valor referente ao receptor $A T_{1}$ pelo valor da alfatubulina e estão representados como média aritmética $\pm E P M .{ }^{*} p<0,05$ comparado com controle da mesma linhagem, ${ }^{*} p<0,05$ comparado com WKY na mesma situação, segundo a análise de variância (ANOVA) de duas vias seguida do pós-teste de Bonferroni. 
Para finalizar, os resultados encontrados acerca dos efeitos do tratamento crônico com nicotina, in vivo, e sua possível relação com o controle da pressão arterial, ou modulação da neurotransmissão estão resumidos na tabela 30 . A ação da nicotina sobre o sistema angiotensinérgico em cultura de células está esquematizado na figura 62.

TABELA 30. Resumo dos resultados obtidos in vivo após tratamento crônico com nicotina.

\begin{tabular}{|l|l|}
\hline Peso & $\leftrightarrow$ \\
\hline Pressão arterial & $\uparrow$ SHR \\
\hline Freqüência Cardíaca & $\uparrow$ SHR \\
\hline NPY-imunohistoquímica & $\uparrow$ NTS e PVN SHR / $\uparrow$ PVNWKY \\
\hline NPY - RNAm & $\leftrightarrow$ \\
\hline Receptores de NPY - ligação & $\downarrow$ NTS SHR e WKY (Y1) / $\downarrow$ NTS SHR e WKY (Y2) \\
\hline TH - imunohistoquímica & $\uparrow$ NTS e PVN WKY e SHR / $\uparrow$ VLM WKY / $\downarrow$ LC SHR \\
\hline TH - RNAm & $\uparrow$ NTS, PVN e LC SHR / $\downarrow$ LC WKY \\
\hline Receptor $\alpha 2$-adrenérgico - RNAm & $\leftrightarrow$ SHR / $\downarrow$ VL, LC e PVN WKY \\
\hline Receptor $\alpha 2$-adrenérgico - ligação & $\leftrightarrow$ \\
\hline Glutamato - imunohistoquímica & $\uparrow$ NTS WKY / $\uparrow$ LC e PVN SHR / $\downarrow$ NTS e VLM SHR \\
\hline Glutamato - RNAm & $\leftrightarrow$ \\
\hline Glutamato - ligação & $\downarrow$ AMPA NMDA KA NTS SHR / $\uparrow$ AMPA LC SHR / $\downarrow$ KA LC SHR \\
\hline ChAT - imunohistoquímica & $\uparrow$ NTS SHR / $\downarrow$ NTS WKY \\
\hline ChAT - RNAm & $\uparrow$ VAGO SHR \\
\hline Receptor nicotínico $\alpha 3$ - RNAm & $\downarrow$ NTS SHR e $\downarrow$ LC WKY \\
\hline Receptor nicotínico $\beta 4-$ RNAm & $\leftrightarrow$ \\
\hline Receptor nicotínico $\alpha 7-$ RNAm & $\downarrow$ LC e PVN WKY \\
\hline AOGEN - RNAm & $\downarrow$ NTS e PVN SHR / $\uparrow$ LC SHR \\
\hline Receptor de Angiotensina II & $\downarrow$ NTS e PVN SHR / $\uparrow$ PVN WKY \\
\hline
\end{tabular}




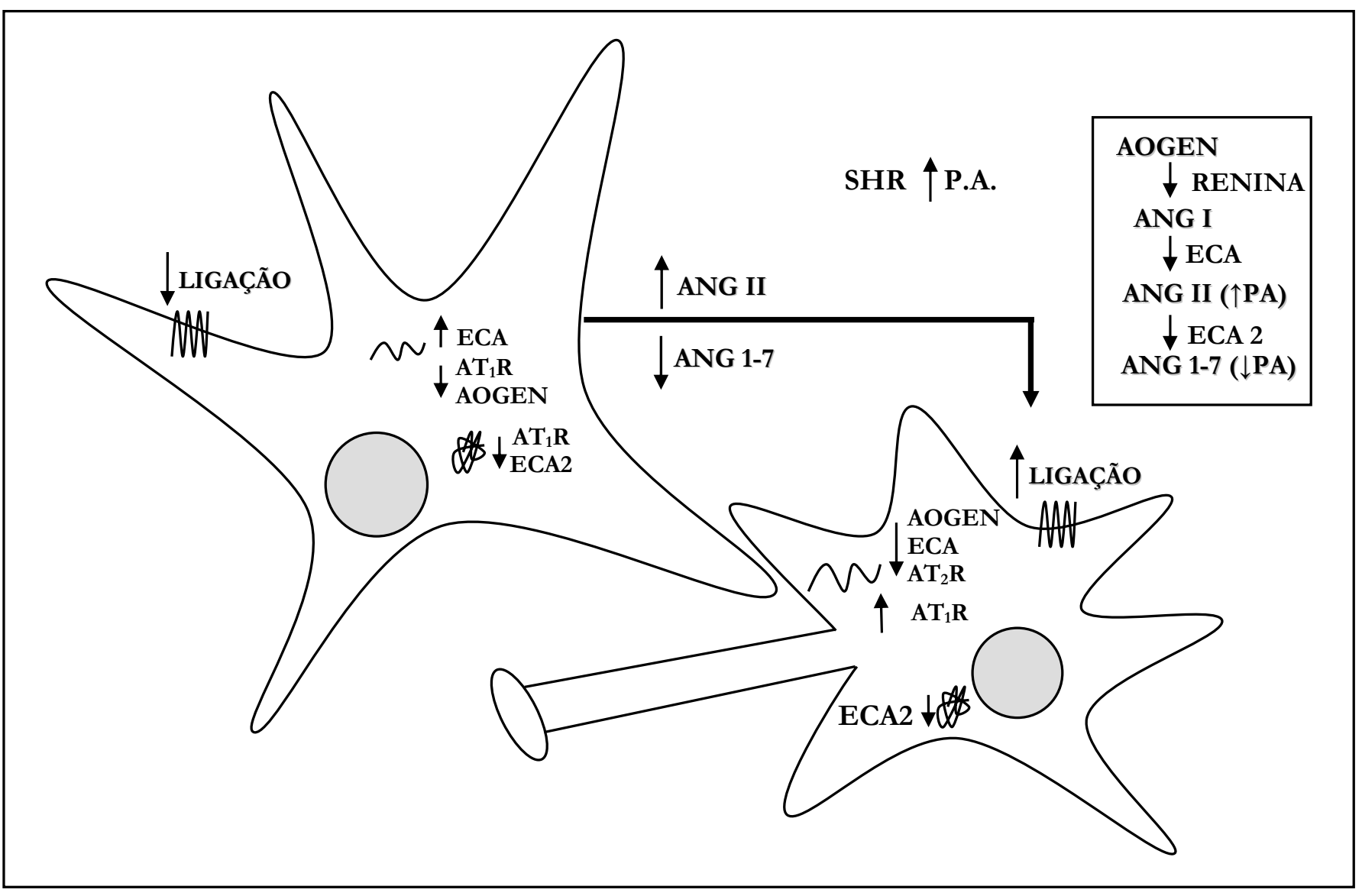

FIGURA 62. Resumo do sistema angiotensinérgico em cultura de células neuronais e gliais de ratos espontaneamente hipertensos, dos efeitos do tratamento com nicotina e sua provável ação facilitatória para o desenvolvimento da hipertensão nesta linhagem de ratos. 
DISCUSSÃO 


\section{Discussão}

Há décadas é conhecido que a nicotina atravessa a barreira hematoencefálica e é capaz de interagir com núcleos encefálicos (IZQUIERDO \& IZQUIERDO, 1971; RIAH et al., 1998). Este fato é bastante explorado especialmente no estudo da dependência a drogas de abuso, como é o caso da nicotina (RYAN \& LOIACONO, 2001; WOOLTORTON et al., 2003), e de doenças neurodegenerativas como a Doença de Parkinson (KELTON et al., 2000; QUIK, 2004).

No entanto, o papel desta droga, importante especialmente para indivíduos com predisposição a hipertensão, na regulação da pressão arterial ainda é obscuro. Assim como ainda não são completamente compreendidos os mecanismos que influenciam o desenvolvimento da hipertensão essencial. Este trabalho estudou os mecanismos envolvidos no controle cardiovascular que implicam no desenvolvimento da hipertensão e são também modificados pela ação da nicotina.

A administração da nicotina através de pastilhas implantadas subcutaneamente permite a infusão contínua e constante de concentrações préestabelecidas da droga. Este método evita picos irregulares de liberação de catecolaminas e outras substâncias no sistema vascular possibilitando a análise adequada da modulação de sistemas de neurotransmissão pela nicotina.

Através da validação do método de quantificação da nicotina e cotinina plasmáticas foi possível determinar que o nível de nicotina presente no plasma em decorrência da liberação pela pastilha escolhida foi de aproximadamente $30 \mathrm{ng} / \mathrm{mL}$ que e é semelhante àquela observada em fumantes moderados (RusSELl et al., 1977; MCNABB, 1984). A correlação linear entre absorbância e concentração foi considerada adequada segundo o que MARTINS e RUDD (1990) recomendam para o $\mathrm{R}^{2}$ que deve pertencer ao intervalo entre 0,9 e 1,0. 
A substituição da pastilha de $10 \mathrm{mg}$ de nicotina após 3 semanas de tratamento por uma de $100 \mathrm{mg}$ fez-se necessária para a correção e manutenção aproximadamente constante da taxa de liberação $(75 \mu \mathrm{g} / \mathrm{h})$ e da quantidade de nicotina presente no sangue destes animais ao longo do dia (8mg/ $\mathrm{kg} / \mathrm{dia})$, conforme BUI e cols. (1994), já que os animais apresentaram considerável ganho de massa corporal.

O aumento abrupto da concentração plasmática de nicotina e cotinina, na semana subseqüente à substituição da pastilha, pode ser devido ao aumento da relação entre a taxa de liberação de nicotina e o peso dos animais que, na primeira semana com a pastilha de maior taxa de liberação, ainda possuíam resquícios da nicotina liberada pela anterior adicionada à nicotina do início da segunda pastilha. Além disso, os ratos possuíam o menor peso necessário para suportarem a quantidade de nicotina liberada pela pastilha. Porém, a quantidade de nicotina presente no plasma voltou aos níveis moderados a partir da segunda semana após a troca das pastilhas, quando os ratos ganharam um pouco mais de peso e já se esgotara completamente a nicotina da pastilha anterior.

Ainda considerando o peso dos animais, diversos trabalhos relatam perda de peso quando do tratamento crônico com nicotina (YETTEFTI et al., 1997; Li et al., 2000; CABANAC \& FrANKHAM, 2002; FrANKHAM \& CABANAC, 2003), correlacionada à estimulação da produção de NPY, orexinas e leptina (LI \& KANE, 2003) ou mesmo excluindo-se a participação da leptina (SANIGORSKI et al., 2002).

No entanto, isso não ocorreu com os animais deste estudo. A resposta para o aparente paradoxo pode residir no fato de todos os trabalhos citados utilizarem o tratamento com doses diárias de nicotina através de injeções, causando os picos de concentração da droga e outros hormônios ou transmissores, efeitos que podem levar à diminuição da ingestão de alimento e 
perda de peso. Além disso, SwISLOCKI e colaboradores (1997) não observaram alteração no peso de ratos tratados com nicotina, também através de implante subcutâneo de pastilhas, durante 3 semanas. Ainda, Assali e cols. (1999) mostraram que indivíduos ex-fumantes continuam a ganhar peso mesmo após a reposição de nicotina através de adesivos transdérmicos, atribuindo a redução do peso não à nicotina, mas a quaisquer outras substâncias presentes nos cigarros.

Outra hipótese a ser considerada é que a infusão contínua de nicotina através das pastilhas durante um período prolongado pode causar anulação da resposta que seria gerada por injeções únicas diárias durante o tratamento. FRANKISH e cols. (1995) confirmam esta hipótese, pois mostraram que a redução da ingestão de alimento ocorre somente com injeção única ou até 3 dias de tratamento com infusão contínua de nicotina, o que vem acompanhado de redução dos níveis de NPY no PVN. No entanto, este mesmo trabalho reportou aumento dos níveis do RNAm deste peptídeo (o qual também possui ação estimulatória sobre o apetite) no tratamento prolongado com nicotina, apesar de ainda observarem alguma perda de peso.

\subsection{Os ratos SHR, os parâmetros cardiovasculares e o tratamento com nicotina.}

A utilização de ratos espontaneamente hipertensos (SHR) é bastante popular já que este é um dos modelos animais mais adequados para o estudo da hipertensão essencial (PINTO et al., 1998; AMENTA et al., 2003).

Estes animais nascem normotensos e desenvolvem a patologia ao atingirem a idade adulta através de mecanismos ainda não muito esclarecidos, mas correlacionados a alterações genéticas. A elevação da pressão arterial nos ratos SHR inicia-se 8 semanas após o nascimento e a hipertensão instala-se com idade de 10 semanas. 
O tratamento com nicotina antecipou o desenvolvimento da patologia nestes animais, pois, como visto, a elevação da pressão arterial deu-se após uma semana do implante das pastilhas de nicotina, quando os animais ainda tinham 5 semanas de idade. A hipertensão também se estabeleceu com esta idade.

Há mais um fator agravante no tratamento com nicotina de ratos com predisposição genética à patologia: a exacerbação da hipertensão. A nicotina não só antecipou o desenvolvimento da hipertensão como também a intensificou. O alcalóide provocou aumento de 22\% na pressão arterial média logo após o implante das pastilhas, e com o decorrer do tratamento a pressão arterial média manteve-se cerca de 10\% acima dos níveis da pressão arterial média dos animais não tratados. A freqüência cardíaca também se encontrou aumentada após tratamento com nicotina, cerca de 8\% ao longo do tratamento.

Qualquer aumento da freqüência cardíaca, dos níveis de pressão arterial e/ou do período em que se é acometido pela hipertensão deve receber especial atenção, pois pode ser um agravante para a morbidade dos indivíduos hipertensos, considerando que o aumento do trabalho cardíaco e a elevação da hipertensão pode ser determinante para a falência de órgãos e tecidos fundamentais para a manutenção da saúde.

Desta forma, tem-se que o abuso à nicotina é um importante fator a ser considerado especialmente por aqueles indivíduos que possuem alguma predisposição genética à hipertensão.

A evolução da pressão e freqüência cardíaca nos ratos SHR foi ao encontro de trabalho prévio (MATTA et al., 1997) confirmando que os indivíduos com predisposição genética à hipertensão são mais sensíveis aos efeitos cardiovasculares da nicotina. No entanto, o presente trabalho foi além ao demonstrar pela primeira vez que animais normotensos não sofrem 
alterações cardiovasculares após exposição a concentrações moderadas de nicotina, mas indivíduos com predisposição genética à hipertensão têm a patologia antecipada e intensificada com o uso da nicotina em doses moderadas e infusão contínua.

Os resultados encontrados corroboram a hipótese de que a antecipação e intensificação da hipertensão em ratos SHR, provocadas pelo tratamento crônico com nicotina, estão de alguma forma relacionadas a alterações dos sistemas de neurotransmissão. Foram encontrados indícios que a neuroquímica das áreas de estudo podem se encontrar alteradas não somente por conta de alterações nos parâmetros cardiovasculares, mas por ação própria da nicotina, como ocorre nos ratos WKY que não tiveram a pressão arterial alterada.

Conforme se pode observar nos resultados obtidos, a modulação dos sistemas de neurotransmissão pela nicotina foi verificada em todas as áreas de interesse e em todos os sistemas de neurotransmissão analisados (não necessariamente sincronizados) o que ilustra a importância da droga na modulação dos sistemas de neurotransmissão envolvidos no controle cardiovascular.

\subsection{O sistema catecolaminérgico e do NPY após tratamento com} nicotina

O aumento das imunorreatividades ao NPY e à TH no NTS e PVN dos ratos tratados com nicotina mostra a interação destes sistemas com o alcalóide no encéfalo. MATTA e cols. (1997) demonstraram a capacidade da nicotina, administrada perifericamente, em estimular a síntese de NPY e TH no NTS e PVN de ratos, e sua relação com a liberação de hormônio adreno-cortico trófico (ACTH). No presente estudo, foi observado que a nicotina pode interagir com estes sistemas de neurotransmissão também para a regulação da pressão arterial. 
O aumento da imunorreatividade à TH no NTS de ratos SHR e WKY pode estar relacionado não somente ao aumento da pressão arterial observado nos SHR, mas à ação da nicotina per se. VALENTINE e colaboradores (1996) mostraram a ativação de células catecolaminérgicas no NTS após injeção intravenosa de nicotina. No presente trabalho pode-se observar que a ativação das células TH positivas no NTS não é devida exclusivamente ao aumento da pressão arterial dos SHR, mas também ao tratamento com nicotina já que os ratos normotensos também responderam.

Para a VLM, temos que somente os ratos WKY, normotensos, tiveram aumento da imunorreatividade à TH com o tratamento de nicotina. Sabendose que a ativação da VLM tem um efeito hipotensor (BLESSING et al., 1982b), pode-se sugerir que há participação deste aumento observado na manutenção dos níveis normais de pressão dos WKY o que não ocorreu nos SHR, mostrando o possível papel desta região e deste sistema de neurotransmissão no desenvolvimento da hipertensão em SHR.

A diminuição da imunorreatividade da TH no LC dos ratos SHR tratados com nicotina foi algo que já se esperava, de certo modo, devido à hipertensão intensificada nestes ratos. SCHNEIDER e cols.(1995) demonstraram diminuição da liberação de catecolaminas no locus coeruleus após estímulo hipertensivo.

Somente os ratos SHR tiveram aumentados os níveis de NPY no NTS e PVN o que poderia indicar a participação deste sistema no controle cardiovascular em indivíduos hipertensos já que o aumento do NPY nestes núcleos pode levar, geralmente, à diminuição da P.A. (HARFSTRAND et al., 1986). Por outro lado, os receptores de NPY no SHR tiveram a ligação diminuída provavelmente devido ao possível aumento da oferta do neuropeptídeo no NTS dos SHR. Como ainda não há meios de se quantificar a relação entre o aumento da liberação do transmissor e a diminuição do receptor, não se pode precisar se a resposta final deste sistema está 
contribuindo para a diminuição da pressão arterial em ratos hipertensos. Assim, como os ratos SHR tratados com nicotina tiveram a hipertensão intensificada, sugere-se que este sistema sozinho não seja suficiente para a inibição da hipertensão, além de poder estar envolvido também em outras funções, como a ingestão de alimento, já mencionado anteriormente.

Foi observado também maior quantidade de receptores Y1 no NTS e PVN de ratos SHR no estado basal, quando comparados com os ratos normotensos. Isso indica a provável participação destes receptores na reversão do quadro hipertensivo nos SHR uma vez que os receptores Y1 estão envolvidos na resposta hipotensora associada à injeção de NPY nestes núcleos (NARVAEZ et al., 1993).

De modo geral, o efeito do tratamento com nicotina sobre os sistemas catecolaminérgico e do NPY não parece ter relação com a antecipação e intensificação da hipertensão os ratos SHR.

A exemplo do que pode acontecer em diversos outros sistemas de neurotransmissão, inclusive para a própria TH (GOZAL et al., 2005), foi observado neste trabalho que o RNAm da TH não se modificou de acordo com sua expressão protéica no LC de ratos tratados com nicotina. O RNAm da tirosina hidroxilase apresentou-se aumentado, ao passo que a proteína diminuiu no LC de ratos SHR tratados com nicotina. Ratos normotensos, da linhagem WKY, quando tratados com nicotina apresentaram diminuição do RNAm da TH, embora sem alteração da síntese de proteína. A alteração diferencial entre as linhagens de ratos sugere a participação deste sistema nos mecanismos de controle cardiovascular.

Estes resultados concordam com os observados por LAMBA et al. (2004) e KANAYAMA et al. (2003) que demonstraram que os RNAm de transmissores podem agir como fatores de transcrição para genes relacionados ao sistema de modulação, ou ainda sofrerem splicing alternativo gerando novas proteínas. Há 
também possibilidade de a meia vida do RNAm sofrer alterações conforme o tratamento fazendo com que a expressão do RNAm seja diferente da proteína.

Os mecanismos de aumento do RNAm da TH sem conseqüente aumento da proteína em ratos SHR é fato a ser analisado posteriormente. A regulação pós-traducional que permite a manutenção dos níveis basais de TH mesmo com a diminuição de seu RNAm em ratos WKY também deve ser investigada.

\subsection{O sistema colinérgico após tratamento com nicotina}

A resposta do sistema colinérgico ao tratamento com nicotina, avaliada através de imunohistoquímica e hibridização in situ da ChAT, foi parecida com o observado para a TH em SHR: aumento do RNAm sem alteração da proteína em ratos espontaneamente hipertensos tratados com nicotina. Interessante notar que este padrão de aumento de RNAm sem conseqüente aumento de proteína foi particularmente encontrado em SHR.

Os dados encontrados para a colina acetiltransferase são bastante interessantes, visto que houve resultados opostos para os ratos normotensos e hipertensos tratados com nicotina.

A acetilcolina é um agente inibitório quando presente no NTS, causando diminuição da pressão arterial e freqüência cardíaca (CRISCIONE et al., 1983; Tsukamoto et al., 1994). A nicotina, como agonista de receptores de acetilcolina, pode fazer com que o sistema colinérgico seja inibido devido à super estimulação de seus receptores. Assim, temos que o aumento da ChAT no NTS dos ratos hipertensos tratados com nicotina pode ser reflexo do aumento da pressão arterial causado pela droga, ao passo que nos ratos normotensos prevaleceu a inibição do sistema com diminuição da ChAT devido ao provável excesso de nicotina no núcleo.

Considerando que a resposta reflexa natural ao aumento de freqüência cardíaca é a ativação dos centros cardioinibitórios, a falta de alterações nos 
núcleos motor dorsal do vago e ambíguo nos ratos SHR, que apresentaram aumento de freqüência cardíaca após tratamento com nicotina, pode ter colaborado para a manutenção dos níveis elevados da FC. O tratamento crônico com nicotina e conseqüente estabilização da elevação de FC podem ter feito com que o sistema se dessensibilizasse nos núcleos motor do vago e ambíguo favorecendo a manutenção da hipertensão nos ratos SHR. Por outro lado, pode-se especular que a ação direta da nicotina sobre estes núcleos estaria colaborando para a manutenção da elevada freqüência cardíaca nos SHR e conseqüentemente facilitando a hipertensão.

A diminuição da quantidade de RNAm da subunidade alfa3 no NTS de ratos SHR e no LC de ratos WKY tratados com nicotina pode ser decorrente da exposição à droga, como mecanismo de regulação para baixo destes receptores. Apesar de haver aumento da ligação dos receptores nicotínicos em indivíduos expostos à droga, este pode ser decorrente da diminuição da reciclagem de receptores na membrana (PENG et al., 1994) e não da síntese de novos receptores.

No entanto, a não alteração do RNAm da subunidade beta4 sugere que as subunidades alfa3 e beta4 podem ser integrantes de outros subtipos de receptores nicotínicos além do $\alpha 3 \beta 4$, pelo menos no NTS e LC. DHAR e colaboradores (2000) demonstraram que a maioria dos receptores nicotínicos, com efeito cardiovascular, presentes no NTS são do subtipo $\alpha 3 \beta 4$. No entanto, a subunidade alfa3 também está relacionada, no NTS, a aferências pulmonares (FERGUSON et al., 2000) podendo explicar em parte a alteração diferencial entre estas 2 subunidades.

A análise somente dos receptores $\alpha 7$ no PVN deveu-se à sua participação majoritária na ações da nicotina sobre este núcleo (ZANINETTTI et al., 2002). 
A diminuição do RNAm dos receptores nicotínicos $\alpha 7$ após tratamento com nicotina somente em ratos WKY sugere a participação deste subtipo de receptor na patologia da hipertensão em SHR após administração de nicotina. Li e BuCCAFusCO (2004) demonstraram a função dos receptores nicotínicos alpha7 no controle cardiovascular. Sua estimulação causa aumento na pressão arterial, assim como seu bloqueio com alfa-bungarotoxina ou metilcacotinina inibe este aumento após injeção de colina no NTS (LI \& BUCCAFUSCO, 2004). Neste sentido, a diminuição dos receptores alpha7 encontrada nos ratos normotensos pode levar à diminuição da resposta pressora após trtamento com nicotina. No entanto, isto não aconteceu em SHR que tiveram a pressão exacerbada pelo tratamento com nicotina.

\subsection{O sistema glutamatérgico e o tratamento com nicotina.}

A modulação da nicotina sobre o sistema glutamatérgico parece ser distinta entre as linhagens de ratos já que a variação da imunorreatividade ao glutamato no NTS apresentou-se de forma oposta nos ratos SHR e WKY após tratamento crônico com nicotina.

Os perfis imunorreativos ao glutamato apresentaram-se diminuídos no NTS de SHR e aumentados em WKY o que pode ser uma evidência da facilitação da hipertensão. ASHWORTH-PRICE e colaboradores (1998) demonstraram aumento da liberação de glutamato no NTS de ratos WKY após injeções sistêmicas de nicotina, estes resultados vão ao encontro dos obtidos neste estudo considerando a estimulação do sistema glutamatérgico em animais normotensos. Entretanto, o presente estudo vai além e demonstra as ações opostas da nicotina administrada perifericamente, sobre o sistema glutamatérgico do NTS de ratos SHR e WKY, ações estas que persistem após longo período de tratamento. Tal fato pode ser mais um a contribuir para o desenvolvimento e intensificação da hipertensão pela nicotina. 
Foi observado também que a nicotina estimulou a imunorreatividade do glutamato no PVN. Neste caso, os resultados da cultura de células ajudam a explicar o fenômeno, pois foi demonstrada a habilidade de a nicotina estimular o sistema angiotensinérgico de neurônios do PVN. Além disso, foi demonstrado que a angiotensina estimula a liberação de glutamato pelo PVN (CATO \& TONEY, 2005) e que a RVLM pode ser excitada por projeções glutamatérgicas vindas do PVN levando a aumento da pressão arterial (DAMPNEY et al., 2005). Portanto, os resultados encontrados na cultura de células combinados com as informações da literatura especializada indicam uma possível ativação secundária do sistema glutamatérgico no PVN, pela nicotina administrada perifericamente, resultando em aumento da pressão arterial em ratos SHR observada após tratamento com nicotina.

A diminuição da imunorreatividade do glutamato na VLM pode ser a única evidência de um mecanismo compensatório do sistema glutamatérgico para diminuição da pressão arterial exclusivamente em ratos SHR. Como é bastante conhecido, o glutamato neste circuito é responsável por estimular o sistema nervoso simpático (AICHER et al., 2000) e, como conseqüência, aumentar a pressão sangüínea. Ora, se a quantidade de glutamato na VLM de SHR está diminuída isto pode revelar uma diminuição, promovida seja pela nicotina ou pelo aumento de pressão, do tônus simpático nestes animais. O que seria contraditório ao recém exposto para o PVN que parece potencializar a transmissão simpática pela RVLM.

Muito embora tanto os receptores de glutamato do subtipo ionotrópico quanto o metabotrópico participam da regulação cardiovascular (OHTA \& TALMAN, 1994; LIU et al., 1998), o presente estudo focalizou primeiramente os receptores dos subtipos NMDA, AMPA e KA, ionotrópicos, após tratamento crônico com nicotina.

Para a análise dos receptores ionotrópicos de glutamato, utilizou-se o ${ }^{3} \mathrm{H}$ Glutamato em solução tampão sem íons de cloro (TAB, cujo pH foi corrigido 
com ácido acético), já que a ligação aos receptores metabotrópicos requer cloro ou bromo. SCHOEPP e TRUE (1992) mostraram a ausência de marcação específica dos receptores metabotrópicos ao utilizarem agonista específico para estes receptores em solução desprovida de íons cloro e/ou bromo. Da mesma forma, os resultados aqui apresentados mostram a especificidade da marcação dos receptores ionotrópicos, pois o deslocamento do ${ }^{3} \mathrm{H}$ glutamato foi total utilizando-se apenas agonistas específicos para os receptores NMDA (MK801), AMPA (quisqualato) e KA (ácido kaínico) em TAB.

Foi demonstrado que o tratamento com nicotina induziu diminuição na ligação dos receptores NMDA, AMPA e KA no NTS somente dos ratos hipertensos sugerindo, novamente, a facilitação da hipertensão nesta linhagem, considerando que a estimulação destes receptores pode levar a diminuição da pressão arterial (HAIBARA et al., 1997; MIYAWAKI et al., 1997; TAKAOKA \& MACHADO, 2003). No NTS, a diminuição da ligação e da imunorreatividade, juntas, podem colaborar com o desenvolvimento da hipertensão quando há predisposição genética para a patologia. Os resultados obtidos por CHAN e cols. (2002) corroboram esta hipótese já que demonstraram que a regulação para cima dos receptores de glutamato no NTS, através da proteína heat shock 70 (HSP70), aumentou a resposta reflexa dos barorreceptores indicando que os receptores de glutamato possuem um papel importante no controle cardiovascular e que a diminuição nos níveis dos mesmos poderia contribuir para o desenvolvimento da hipertensão.

No locus coeruleus, o glutamato pode possuir ação hipertensora (CHEN \& HUANG, 1997) através da ativação de receptores AMPA (CHEN et al., 1997). No presente trabalho foi mostrado aumento da imunorreatividade da glutaminase e da ligação dos receptores AMPA exclusivamente no LC de SHR sugerindo, então, que a nicotina pode aumentar a transmissão glutamatérgica neste núcleo facilitando a hipertensão em ratos espontaneamente hipertensos. Como não há dados suficientes que relacionam o papel do receptor KA no LC 
e o controle cardiovascular, e já que o sistema glutamatérgico está colaborando para o desenvolvimento da hipertensão, após tratamento com nicotina, em praticamente todos os núcleos analisados, pode-se supor que esta seja mais uma evidência da facilitação da hipertensão pela nicotina em ratos com predisposição genética à hipertensão.

Os resultados apresentados aqui demonstraram alterações na imunorreatividade do glutamato sem, no entanto, haver alteração dos níveis de RNAm da glutaminase. Foram demonstrados recentemente os efeitos da nicotina sobre a regulação pós-transcricional da tirosina hidroxilase na medula adrenal (YOSHIMURA et al., 2004) e no locus coeruleus (OsTERHOUT et al., 2005). Até onde se sabe, não há relatos deste tipo de modulação sobre o sistema glutamatérgico. No entanto, os resultados apresentados podem ser decorrentes da modulação pós-transcricional/traducional do sistema glutamatérgico pela nicotina. Há de se ressaltar, também, que a atividade enzimática pode ser também modulada pela nicotina. Experimentos em cultura de células, semelhantes aos que analisaram o sistema angiotensinérgico, deverão ser conduzidos para melhor compreensão da modulação do sistema glutamatérgico e da própria gênese da hipertensão pela nicotina.

Do sistema glutamatérgico pode-se concluir que a antecipação e intensificação da hipertensão em ratos SHR estão pelo menos em parte relacionadas a este sistema.

\subsection{O sistema angiotensinérgico e o tratamento com nicotina.}

É bem conhecido que a angiotensina II promove aumento da pressão arterial quando injetada no NTS e PVN de ratos (CASTO \& PHILLIPS, 1984; PHILlips \& SuMNERS, 1998), portanto os resultados obtidos podem ser coerentes como respostas à hipertensão: diminuição dos níveis de angiotensina 
II no NTS e PVN de ratos SHR que tiveram a pressão elevada pela administração crônica de nicotina.

A diminuição dos receptores de angiotensina nestes núcleos em SHR pode ajudar na resposta hipotensora para reversão do quadro hipertensivo reduzindo ainda mais a resposta angiotensinérgica.

Por outro lado, diminuição do RNAm não necessariamente indica diminuição da proteína. Podendo inclusive resultar em aumento da proteína e, neste caso, os resultados vão ao encontro da facilitação da hipertensão.

O mecanismo de aumento da proteína e diminuição do RNAm já foi demonstrado em outro sistema. SALLINEN e cols. (2005) mostraram que a diminuição do RNAm dos receptores de melatonina na glândula pineal vem acompanhada e aumento da proteína durante uma fase posterior do ciclo biológico. Se isso também acontecer para a angiotensina, então temos que a nicotina facilita a transmissão angiotensinérgica colaborando para o desenvolvimento da hipertensão.

A problemática da quantificação da angiotensina II poderia ser solucionada se houvesse anticorpos comercialmente disponíveis que funcionassem adequadamente, assim a imunohistoquímica seria viável e estas dúvidas estariam minimizadas.

No LC, os ratos SHR apresentaram aumento da expressão gênica do angiotensinogênio. A exemplo do que acontece no NTS e PVN, a angiotensina promove aumento na pressão arterial quando administrada no LC (SPETH et al., 1991), com isso, para ratos SHR, o tratamento com nicotina pode implicar em facilitação do desenvolvimento da hipertensão. Entretanto, as ações da angiotensina II no LC podem não ter relação direta com a pressão arterial, pois o peptídeo participa também das respostas ao estresse (DUMONT et al., 1999) e regulação neuroendócrina do metabolismo de sais e água (MCCANN et al., 1997). 
Alguns resultados podem parecer controversos já que houve alteração da imunorreatividade ao glutamato, à TH e ao NPY, mas a quantidade de seus respectivos RNAm mantiveram-se inalteradas ou a alteração pareceu pouco "coerente" com o que se esperava com o tratamento crônico com nicotina. No entanto, este fenômeno é bastante comum especialmente no caso de tratamento longo como o que foi feito neste trabalho, pois a modulação não se restringe à expressão gênica e liberação do neurotransmissor, mas pode interferir também na cinética enzimática modificando a velocidade de degradação do transmissor e na expressão gênica de outras proteínas regulatórias agindo como modulador pós-transcricional (KEILHOFF et al., 1996). Além disso, como discutido anterirmente, o RNAm do transmissor pode agir como fator de transcrição, sofrer splicing alternativo e ter a meia vida modificada.

Conforme já foi extensivamente comentado, os sistemas de neurotransmissão podem ser modulados tanto pela alteração da pressão arterial quanto por agentes exógenos através de sua ação direta. Para tentar elucidar a participação de cada um destes fatores, separadamente, sobre a regulação dos sistemas de neurotransmissão foram feitas culturas de células que foram tratadas com nicotina. O primeiro sistema analisado foi o angiotensinérgico. Considerando a compartimentalização deste sistema no sistema nervoso central, foi necessário cultivar células gliais e neuronais separadamente.

Os dados aqui apresentados mostram, pela primeira vez, evidências de que a nicotina modula diretamente o sistema angiotensinérgico em células gliais e neuronais, e que esta ação é diferenciada entre ratos SHR e WKY, sendo os primeiros talvez mais sensíveis à ação da droga que os ratos normotensos. Foi evidenciado também que esta ação da nicotina sobre o sistema angiotensinérgico é anterior ao aparecimento da hipertensão (visto que foram utilizados ratos de um dia de vida para a cultura de células) e, portanto, envolve modulação de sistemas que possivelmente estão envolvidos na gênese da 
patologia. Este dado é importante para ajudar a explicar a ação da nicotina em antecipar o desenvolvimento da hipertensão, em SHR.

Como já mostrado, o efeito da nicotina administrada perifericamente é diferencial entre as linhagens de ratos: dose moderada da droga não provoca efeito hipertensor na linhagem normotensa, enquanto que em SHR a mesma dose de nicotina promove antecipação e intensificação da hipertensão o que pode evidenciar o efeito do alcalóide sobre os genes que estão envolvidos no controle cardiovascular e cuja regulação é diferenciada entre as linhagens normotensa e hipertensa. Estes resultados in vitro ajudarão a explicar os fenômenos cardiovasculares observados após administração de nicotina in vivo.

A ação hipertensora da angiotensina quando administrada no sistema nervoso central deve-se principalmente à estimulação dos receptores $\mathrm{AT}_{1}$ já que o bloqueio destes receptores abole completamente este efeito (FORNES et al., 1993; GorbeA-Oppliger et al., 1994; Unger, 2003). Sendo assim, o aumento na ligação dos receptores de angiotensina provocado pela nicotina em cultura de células gliais e neuronais de SHR explica em parte os resultados observados em experimentos in vivo: aumento da pressão arterial em ratos SHR, mas não em WKY, indicando a relação da hipertensão provocada pela nicotina com o sistema angiotensinérgico em células gliais e neurônios. É importante ressaltar ainda que o sistema angiotensinérgico também seja modulado pelas variações da pressão arterial, por isso a relevância dos estudos in vivo e in vitro, dissociando desta forma a ação da nicotina sobre o sistema angiotensinérgico da ação da variação da pressão arterial sobre este mesmo sistema.

Interessantemente, foi observado que a ligação dos receptores de angiotensina é maior em neurônios de SHR do que de WKY no estado basal quando em cultura. O que pode colaborar para o desenvolvimento da hipertensão no animal SHR. A participação da nicotina neste caso parece ser de aumentar, direta ou indiretamente, a ligação dos receptores de angiotensina 
o que pode colaborar também com a elevação da pressão. Esta diferença fisiológica encontrada em cultura de células de SHR e WKY entre as linhagens pode ser uma evidência da já bem conhecida participação do sistema angiotensinérgico na gênese da hipertensão neurogênica (ESHIMA et al., 2000; MANN, 2003), sendo intensificada com administração de nicotina.

O aumento da ligação dos receptores de angiotensina provocado pela nicotina resume-se a células gliais do tronco encefálico e em co-cultura, a glia do hipotálamo de SHR apresentou menor ligação que em WKY após tratamento com nicotina. Sabe-se que uma das ações da angiotensina II quando microinjetada no núcleo paraventricular do hipotálamo é de estimular a liberação de vasopressina (STECKELINGS et al., 1992; HATAE et al., 2001), hormônio reconhecidamente hipertensor, assim a diminuição da ligação dos receptores $\mathrm{AT}_{1} \mathrm{R}$ em hipotálamo de ratos SHR após administração de nicotina indica a ação diferencial da droga em diferentes núcleos encefálicos responsáveis, dentre outras coisas, pelo controle cardiovascular. Além disso, pode-se ter a ação da nicotina sobre a angiotensina II para a modulação de diversos outros sistemas de regulação fisiológica como no caso do estresse (DUMONT et al., 1999) e do metabolismo de sais e água (MCCANN et al., 1997).

A ligação encontrada nas células gliais em co-cultura é o resultado da somatória dos valores referentes ao tronco encefálico e hipotálamo, prevalecendo o aumento já que a magnitude da resposta no tronco encefálico foi maior que a diminuição encontrada no hipotálamo. Desta forma, o estudo das áreas encefálicas em culturas separadas torna-se importante para análise e interpretação da interação entre a nicotina e os sistemas de modulação da pressão arterial, pois, como exemplificado, a resposta varia diferentemente conforme a composição da cultura de células.

A ligação dos receptores $\mathrm{AT}_{2}$ neuronais também foi aumentada pela ação da nicotina, mas de forma muito mais discreta, somente com $100 \mu \mathrm{M}$ da 
droga ou após 12 horas de incubação. O RNAm diminuiu com a nicotina nas duas linhagens, mas a quantidade de proteína aumentou em WKY e não se alterou em SHR. A exemplo do que acontece com os receptores $\mathrm{AT}_{1}$, ratos SHR também apresentaram maior ligação e quantidade de RNAm de receptores $\mathrm{AT}_{2}$ em neurônios. As duas bandas presentes no gel foram quantificadas, sem, todavia, apresentarem diferenças quanto à resposta ao tratamento com nicotina.

A diferença de peso molecular entre as bandas correspondentes ao receptor $\mathrm{AT}_{2}$ de angiotensina II deve-se provavelmente ao estado fisiológico da molécula. PAXTON e colaboradores (1994) e PORTER (1999) observaram diferentes pesos moleculares para o receptor $\mathrm{AT}_{1}$ de angiotensina em tecido nervoso e atribuíram essa diferença à glicosilação do receptor. Talvez, as duas bandas encontradas neste estudo para os receptores $\mathrm{AT}_{2}$ de angiotensina podem ser resultado da marcação de receptores acoplados ou não à glicose. Esse subtipo de receptor não foi analisado em cultura de células gliais uma vez que já se demonstrou sua pouca densidade em células da glia (SUMNERS et al., 1991).

Os receptores $\mathrm{AT}_{2}$ de angiotensina II estão relacionados ao desenvolvimento, diferenciação celular e apoptose (AlLEN et al., 1999; KASCHINA \& UNGER, 2003), mas também participam do controle cardiovascular onde sua ação é contrária às ações decorrentes da ativação dos receptores $\mathrm{AT}_{1}$, ou seja, há diminuição da pressão quando são ativados (LI et al., 2003; WANG et al., 2004). Sabendo disso, tem-se que a nicotina não alterando os níveis de receptores $\mathrm{AT}_{2}$ e aumentando os receptores $\mathrm{AT}_{1}$ colabora para que o resultado seja pressórico.

Vale a pena ressaltar que a razão entre os receptores $\mathrm{AT}_{1}$ e $\mathrm{AT}_{2}$ de angiotensina no rato aumenta confome o desenvolvimento, portanto os níveis de receptores $\mathrm{AT}_{2}$ são mais elevados em animais jovens, como aqueles utilizados na cultura de células. É possível que a diminuição deste subtipo de 
receptor, associado ao aumento dos receptores $\mathrm{AT}_{1}$ favoreça $\mathrm{O}$ desenvolvimento da hipertensão em animais SHR adultos. Recentemente, SILVA-ANTONIALLI e colaboradoras (2004) verificaram que fêmeas SHR possuem menor relação $\mathrm{AT}_{1} / \mathrm{AT}_{2}$ no endotélio que machos da mesma linhagem e atribuíram a menor pressão arterial encontrada em fêmeas a esta diferença na proporção entre os receptores de angiotensina. Da mesma forma, o desbalanço entre esses subtipos de receptores em áreas do sistema nervoso central que controlam a pressão arterial pode facilitar a hipertensão.

O tratamento com nicotina promoveu diminuição também mais acentuada do RNAm do angiotensinogênio em neurônios de SHR que de WKY. Na cultura de células gliais a quantidade de angiotensinogênio foi aumentada com a nicotina em ratos SHR após 48 horas de tratamento. A ação da droga sobre o angiotensinogênio nos ratos hipertensos também foi mais acentuada corroborando a idéia de que a nicotina modula o sistema angiotensinérgico especialmente na linhagem hipertensa e que pode ajudar no desenvolvimento da hipertensão após exposição crônica à droga.

É bastante conhecido que o angiotensinogênio proveniente dos astrócitos são os principais colaboradores para a regulação da pressão arterial (YANG et al., 1999; MCKINLEY et al., 2003; SAKAI et al., 2004), sendo que a angiotensina II formada pelos neurônios a partir do angiotensinogênio intracelular dos neurônios ainda não foi devidamente correlacionada ao controle cardiovascular (LAVOIE \& SigmuND, 2003). Além disso, é a angiotensina formada extracelularmente que é capaz de interagir no sistema nervoso central para a modulação da pressão arterial (LAVOIE \& SIGMUND, 2003). Assim, as ações da nicotina sobre as células gliais para a modulação do sistema angiotensinérgico podem ser muito relevantes para o desenvolvimento da hipertensão em ratos SHR. 
O aumento observado do RNAm da ECA na glia somente de SHR pode refletir em diminuição do angiotensinogênio, e, provavelmente, aumento de angiotensina disponível.

Estes resultados concordam com o encontrado por SUGIYAMA e colaboradores (1988) que observaram aumento da atividade da enzima conversora de angiotensina associado ao fumo em macrófagos encontrados no pulmão destes fumantes.

A hipertensão pode ainda estar sendo favorecida pela diminuição da ECA2, que gera angiotensina 1-7 com efeito hipotensor, em SHR comparado com WKY na situação controle e que é agravada após tratamento com nicotina.

Outro fator importante é a metabolização mais lenta da angiotensina II em SHR comparado com WKY relatada por HERMANN e colaboradores (1989). Estes investigadores observaram que os ratos SHR possuem cerca de 3 vezes menos degradação da angiotensina II que WKY.

De forma generalizada, os resultados de análise da ligação dos receptores de angiotensina e do RNAm do sistema angiotensinérgico indicam que a ação da nicotina sobre alguns dos núcleos encefálicos responsáveis pelo controle cardiovascular parece ser para o favorecimento da hipertensão em ratos SHR.

Em conclusão, os dados apresentados demonstram que a nicotina modula o sistema angiotensinérgico no sistema nervoso central diferentemente em ratos SHR e WKY e isso pode estar relacionado à capacidade de a nicotina antecipar e intensificar a hipertensão nos indivíduos predispostos à patologia.

Os resultados apresentados aqui também são muito importantes para rever e avaliar terapias de reposição de nicotina através de adesivos transdérmicos naqueles que decidem parar de fumar e têm alguma evidência de predisposição genética à hipertensão, já que foi demonstrado que a infusão 
crônica e contínua de doses moderadas de nicotina antecipa e intensifica a hipertensão nestes indivíduos.

Além disso, foi demonstrado que o efeito da nicotina administrada perifericamente é diferencial entre as linhagens de ratos: dose moderada da droga não provoca efeito hipertensor na linhagem normotensa, enquanto que em SHR a mesma dose de nicotina promove antecipação e intensificação da hipertensão o que pode evidenciar o efeito do alcalóide sobre os genes que estão envolvidos no controle cardiovascular e cuja regulação é diferenciada entre as linhagens normotensa e hipertensa. Estes resultados ajudarão a explicar os fenômenos cardiovasculares observados após administração de nicotina, assim como, compreender melhor os mecanismos e genes envolvidos no desencadeamento da hipertensão essencial. 
CONCLUSÕES 


\section{ConClusões}

Com base nos resultados apresentados pode-se concluir que:

1) $O$ tratamento crônico com doses moderadas de nicotina não afeta o peso corporal

2) Doses moderadas de nicotina favorece o desenvolvimento da hipertensão somente em ratos com predisposição genética para a patologia. Assim, o abuso à nicotina deve ser considerado especialmente pelos indivíduos que possuem algum fator genético para a hipertensão.

3) A modulação da neurotransmissão pela nicotina parece ocorrer com maior magnitude em indivíduos com predisposição genética à hipertensão, pois ratos SHR respondem a menores concentrações da droga que os normotensos.

4) Há sistemas de neurotransmissão, como o angiotensinérgico e o glutamatérgico, que parecem facilitar o desenvolvimento da hipertensão após tratamento com nicotina;

5) Algumas das alterações nos sistemas de neurotransmissão podem decorrer da hipertensão e não parecem estar diretamente envolvidas com a gênese da hipertensão promovida pela nicotina, como é o caso das catecolaminas e do NPY. 
REFERÊNCIAS BIBLIOGRÁFICAS 


\section{REFERÊNCIAS BIBLIOGRÁFICAS}

AAntAA, R., MARjAMAKI, A. \& SCHEInin, M. Molecular pharmacology of alpha 2-adrenoceptor subtypes. Ann Med, 1995, 27, 439-49.

Aberger, K., Chitravanshi, V. C. \& Sapru, H. N. Cardiovascular responses to microinjections of nicotine into the caudal ventrolateral medulla of the rat. Brain Res, 2001, 892, 138-46.

Aicher, S. A., Milner, T. A., Pickel, V. M. \& Reis, D. J. Anatomical substrates for baroreflex sympathoinhibition in the rat. Brain Res Bull, 2000, 51, 107-10.

Allen, A. M., Zhuo, J. \& Mendelsohn, F. A. Localization of angiotensin AT1 and AT2 receptors. J Am Soc Nephrol, 1999, 10 Suppl 11, S23-9.

Almeida, R. S., Ferrari, M. F. \& FIOR-Chadi, D. R. Quantitative autoradiography of adrenergic, neuropeptide $\mathrm{Y}$ and angiotensin II receptors in the nucleus tractus solitarii and hypothalamus of rats with experimental hypertension. Gen Pharmacol, 2000, 34, 343-8.

Amendt, K., Czachurski, J., Dembowsky, K. \& Seller, H. Bulbospinal projections to the intermediolateral cell column: a neuroanatomical study. J Auton Nerv Syst, 1979, 1, 103-7.

Amenta, F., Di Tullio, M. A. \& Tomassoni, D. Arterial hypertension and brain damage--evidence from animal models (review). Clin Exp Hypertens, 2003, 25, 359-80.

Arnolda, L., Minson, J., Kapoor, V., Pilowsky, P., Llewellyn-Smith, I. \& Chalmers, J. Amino acid neurotransmitters in hypertension. Kidney Int Supp1, 1992, 37, S2-7.

Ashworth-Preece, M., Jarrott, B. \& LAwrence, A. J. Nicotinic acetylcholine receptors in the rat and primate nucleus tractus solitarius and on rat and human inferior vagal (nodose) ganglia: evidence from in vivo microdialysis and [125I]alpha-bungarotoxin autoradiography. Neuroscience, 1998, 83, 1113-22.

Ashworth-Preece, M., Krstew, E., Jarrott, B. \& Lawrence, A. J. Functional GABAA receptors on rat vagal afferent neurones. $B \mathbf{r} \mathbf{J}$ Pharmacol, 1997, 120, 469-75. 
Assali, A. R., Beigel, Y., Schreibman, R., Shafer, Z. \& Fainaru, M. Weight gain and insulin resistance during nicotine replacement therapy. Clin Cardiol, 1999, 22, 357-60.

Bahner, U., Geiger, H., Palkovits, M., Luft, F. C. \& Heidland, A. Angiotensin II-induced hypertension: effects on central and peripheral atrial natriuretic peptide. Hypertens Res, 1995, 18, 279-84.

BALFOUR, D. J. The effects of nicotine on brain neurotransmitter systems. Pharmacol Ther, 1982, 16, 269-82.

BARIK, J. \& WONNACOTT, S. Indirect modulation by alpha7 nicotinic acetylcholine receptors of noradrenaline release in rat hippocampal slices: interaction with glutamate and GABA systems and effect of nicotine withdrawal. Mol Pharmacol, 2006, 69, 618-28.

Benfenati, F., Cimino, M., Agnati, L. F. \& Fuxe, K. Quantitative autoradiography of central neurotransmitter receptors: methodological and statistical aspects with special reference to computer-assisted image analysis. Acta Physiol Scand, 1986, 128, 129-46.

Benowitz, N. L. Cigarette smoking and nicotine addiction. Med Clin North Am, 1992, 76, 415-37.

BHAGAT, B. Effects of chronic administration of nicotine on storage and synthesis of noradrenaline in rat brain. Br J Pharmacol, 1970, 38, 8692.

Bhargava, K. P., Jain, I. P., Saxena, A. K., Sinha, J. N. \& Tangri, K. K. Central adrenoceptors and cholinoceptors in cardiovascular control. $\mathbf{B r}$ J Pharmacol, 1978, 63, 7-15.

Blessing, W. W., Goodchild, A. K., Dampney, R. A. \& Chalmers, J. P. Cell groups in the lower brain stem of the rabbit projecting to the spinal cord, with special reference to catecholamine-containing neurons. Brain Res, 1981, 221, 35-55.

Blessing, W. W., Jaeger, C. B., Ruggiero, D. A. \& Reis, D. J. Hypothalamic projections of medullary catecholamine neurons in the rabbit: a combined catecholamine fluorescence and HRP transport study. Brain Res Bull, 1982a, 9, 279-86.

Blessing, W. W., Sved, A. F. \& ReIS, D. J. Destruction of noradrenergic neurons in rabbit brainstem elevates plasma vasopressin, causing hypertension. Science, 1982b, 217, 661-3. 
Brain, S. D. \& Cox, H. M. Neuropeptides and their receptors: innovative science providing novel therapeutic targets. Br J Pharmacol, 2006, 147 Suppl 1, S202-11.

Brezenoff, H. E. Cardiovascular regulation by brain acetylcholine. Fed Proc, 1984, 43, 17-20.

BREzenofF, H. E. \& CAPUTI, A. P. Intracerebroventricular injection of hemicholinium-3 lowers blood pressure in conscious spontaneously hypertensive rats but not in normotensive rats. Life Sci, 1980, 26, 103745.

Bui, L. M., KeEn, C. L. \& DubiCK, M. A. Influence of 12-week nicotine treatment and dietary copper on blood pressure and indices of the antioxidant system in male spontaneous hypertensive rats. Biol Trace Elem Res, 1994, 46, 67-78.

CABAnAC, M. \& FrankHAM, P. Evidence that transient nicotine lowers the body weight set point. Physiol Behav, 2002, 76, 539-42.

Campagnole-Santos, M. J., Diz, D. I., Santos, R. A., Khosla, M. C., Brosnihan, K. B. \& Ferrario, C. M. Cardiovascular effects of angiotensin-(1-7) injected into the dorsal medulla of rats. Am J Physiol, 1989, 257, H324-9.

Campagnole-Santos, M. J., Heringer, S. B., Batista, E. N., Khosla, M. C. \& SANTOS, R. A. Differential baroreceptor reflex modulation by centrally infused angiotensin peptides. Am J Physiol, 1992, 263, R8994.

CAsto, R. \& Phillips, M. I. Cardiovascular actions of microinjections of angiotensin II in the brain stem of rats. Am J Physiol, 1984, 246, R8116.

Casto, R. \& Phillips, M. I. Neuropeptide action in nucleus tractus solitarius: angiotensin specificity and hypertensive rats. Am J Physiol, 1985, 249, R341-7.

CASto, R. \& Phillips, M. I. Angiotensin II attenuates baroreflexes at nucleus tractus solitarius of rats. Am J Physiol, 1986, 250, R193-8.

Cato, M. J. \& Toney, G. M. Angiotensin II excites paraventricular nucleus neurons that innervate the rostral ventrolateral medulla: an in vitro patch-clamp study in brain slices. J Neurophysiol, 2005, 93, 403-13. 
Chadi, G., Cao, Y., Pettersson, R. F. \& Fuxe, K. Temporal and spatial increase of astroglial basic fibroblast growth factor synthesis after 6hydroxydopamine-induced degeneration of the nigrostriatal dopamine neurons. Neuroscience, 1994, 61, 891-910.

Chadi, G., Moller, A., Rosen, L., Janson, A. M., Agnati, L. A., Goldstein, M., Ogren, S. O., Pettersson, R. F. \& Fuxe, K. Protective actions of human recombinant basic fibroblast growth factor on MPTP-lesioned nigrostriatal dopamine neurons after intraventricular infusion. Exp Brain Res, 1993, 97, 145-58.

Chan, S. H., Chang, K. F., Ou, C. C. \& Chan, J. Y. Up-regulation of glutamate receptors in nucleus tractus solitarii underlies potentiation of baroreceptor reflex by heat shock protein 70. Mol Pharmacol, 2002, 61, 1097-104.

Chen, S. Y., Wu, W. C., Tseng, C. J., KuO, J. S. \& Chai, C. Y. Involvement of non-NMDA and NMDA receptors in glutamate-induced pressor or depressor responses of the pons and medulla. Clin Exp Pharmacol Physiol, 1997, 24, 46-56.

CHEN, Y. Y. \& HuAng, Z. S. Stimulation of locus coeruleus increases arterial pressure in rabbits. Zhongguo Yao Li Xue Bao, 1997, 18, 437-40.

Chesselet, M. F. Presynaptic regulation of neurotransmitter release in the brain: facts and hypothesis. Neuroscience, 1984, 12, 347-75.

Clarke, P. B., Schwartz, R. D., Paul, S. M., Pert, C. B. \& Pert, A. Nicotinic binding in rat brain: autoradiographic comparison of $[3 \mathrm{H}]$ acetylcholine, $[3 \mathrm{H}]$ nicotine, and $[125 \mathrm{I}]$-alpha-bungarotoxin. J Neurosci, 1985, 5, 1307-15.

Criscione, L., Reis, D. J. \& TAlman, W. T. Cholinergic mechanisms in the nucleus tractus solitarii and cardiovascular regulation in the rat. Eur $\mathbf{J}$ Pharmacol, 1983, 88, 47-55.

Cryer, P. E., Haymond, M. W., Santiago, J. V. \& Shah, S. D. Norepinephrine and epinephrine release and adrenergic mediation of smoking-associated hemodynamic and metabolic events. $\mathbf{N}$ Engl J Med, 1976, 295, 573-7.

Dahlstroem, A. \& Fuxe, K. Evidence for the Existence of MonoamineContaining Neurons in the Central Nervous System. I. Demonstration of Monoamines in the Cell Bodies of Brain Stem Neurons. Acta Physiol Scand, 1964, 62, SUPPL 232:1-55. 
DAIKHIN, Y. \& YUdKOFF, M. Compartmentation of brain glutamate metabolism in neurons and glia. J Nutr, 2000, 130, 1026S-31S.

DAJAS-BAILADOR, F. \& WONNACOTT, S. Nicotinic acetylcholine receptors and the regulation of neuronal signalling. Trends Pharmacol Sci, 2004, 25, 317-24.

DAMPNEY, R. A. Brain stem mechanisms in the control of arterial pressure. Clin Exp Hypertens, 1981, 3, 379-91.

DAMPNEY, R. A. Functional organization of central pathways regulating the cardiovascular system. Physiol Rev, 1994, 74, 323-64.

Dampney, R. A., Goodchild, A. K., Robertson, L. G. \& Montgomery, W. Role of ventrolateral medulla in vasomotor regulation: a correlative anatomical and physiological study. Brain Res, 1982, 249, 223-35.

Dampney, R. A., Horiuchi, J., Killinger, S., Sheriff, M. J., Tan, P. S. \& MCDOWALL, L. M. Long-term regulation of arterial blood pressure by hypothalamic nuclei: some critical questions. Clin Exp Pharmacol Physiol, 2005, 32, 419-25.

Dampney, R. A., Horiuchi, J., Tagawa, T., Fontes, M. A., Pot'ts, P. D. \& POLSON, J. W. Medullary and supramedullary mechanisms regulating sympathetic vasomotor tone. Acta Physiol Scand, 2003, 177, 209-18.

DANI, J. A. Overview of nicotinic receptors and their roles in the central nervous system. Biol Psychiatry, 2001, 49, 166-74.

DE JONG, W. Noradrenaline: central inhibitory control of blood pressure and heart rate. Eur. J. Pharmacol., 1974, 29, 179-181.

Dhar, S., Nagy, F., McIntosh, J. M. \& Sapru, H. N. Receptor subtypes mediating depressor responses to microinjections of nicotine into medial NTS of the rat. Am J Physiol Regul Integr Comp Physiol, 2000, 279, R132-40.

Diaz-Cabiale, Z., Fuxe, K., Covenas, R., Gonzalez-Baron, S. \& NArvaEZ, J. A. Angiotensin II modulates the cardiovascular responses to microinjection of NPY Y1 and NPY Y2 receptor agonists into the nucleus tractus solitarii of the rat. Brain Res, 2003, 983, 193-200.

Donoghue, M., Hsieh, F., Baronas, E., Godbout, K., Gosselin, M., Stagliano, N., Donovan, M., Woolf, B., Robison, K., JeyaseElan, R., Breitbart, R. E. \& ACTON, S. A novel angiotensin-converting 
enzyme-related carboxypeptidase (ACE2) converts angiotensin I to angiotensin 1-9. Circ Res, 2000, 87, E1-9.

Dumont, E. C., Rafrafi, S., LAForest, S. \& Drolet, G. Involvement of central angiotensin receptors in stress adaptation. Neuroscience, 1999, 93, 877-84.

DZIMIRI, N. Receptor crosstalk. Implications for cardiovascular function, disease and therapy. Eur J Biochem, 2002, 269, 4713-30.

EngElmann, M., LAndgraf, R. \& WOTJAK, C. T. The hypothalamicneurohypophysial system regulates the hypothalamic-pituitary-adrenal axis under stress: an old concept revisited. Front Neuroendocrinol, 2004, 25, 132-49.

ErdtMann-Vourliotis, M., MAyer, P., Riechert, U., HAndel, M., KRIEBITZSCH, J. \& HOLLT, V. Rational design of oligonucleotide probes to avoid optimization steps in in situ hybridization. Brain Res Brain Res Protoc, 1999, 4, 82-91.

Eshima, K., Hirooka, Y., Shigematsu, H., Matsuo, I., Koike, G., Sakai, K. \& TAKeshitA, A. Angiotensin in the nucleus tractus solitarii contributes to neurogenic hypertension caused by chronic nitric oxide synthase inhibition. Hypertension, 2000, 36, 259-63.

Ferguson, D. G., Haxhiu, M. A., To, A. J., Erokwu, B. \& Dreshaj, I. A. The alpha3 subtype of the nicotinic acetylcholine receptor is expressed in airway-related neurons of the nucleus tractus solitarius, but is not essential for reflex bronchoconstriction in ferrets. Neurosci Lett, 2000, $287,141-5$.

Ferrari, R., Pedrazzi, P., Algeri, S., Agnati, L. F. \& Zoli, M. Subunit and region-specific decreases in nicotinic acetylcholine receptor mRNA in the aged rat brain. Neurobiol Aging, 1999, 20, 37-46.

Ferreira, A. J. \& SANTOS, R. A. Cardiovascular actions of angiotensin-(1-7). Braz J Med Biol Res, 2005, 38, 499-507.

Ferreira, M., Singh, A., Dretchen, K. L., Kellar, K. J. \& Gillis, R. A. Brainstem nicotinic receptor subtypes that influence intragastric and arterial blood pressures. J Pharmacol Exp Ther, 2000, 294, 230-8.

FIOR, D. R. \& FUXE, K. Bradykinin modulation of alpha 2-adrenoceptors in the nucleus tractus solitarii of the rat. An in vitro autoradiographical study. Neuropharmacology, 1995, 34, 81-8. 
Fior, D. R., Yang, S. N., Hedlund, P. B., Narvaez, J. A., Agnati, L. F. \& FUXE, K. Evidence for an antagonistic angiotensin II/alpha 2adrenoceptor interaction in the nucleus tractus solitarii. Eur J Pharmacol, 1994, 262, 271-82.

FIOR-CHADI, D. R. \& FUXE, K. Quantitative receptor radioautography in the study of receptor-receptor interactions in the nucleus tractus solitarii. Braz J Med Biol Res, 1998, 31, 225-30.

Fishman, M. C., Zimmerman, E. A. \& Slater, E. E. Renin and angiotensin: the complete system within the neuroblastoma $\mathrm{x}$ glioma cell. Science, 1981, 214, 921-3.

Fontes, M. A., Silva, L. C., Campagnole-Santos, M. J., Khosla, M. C., Guertzenstein, P. G. \& Santos, R. A. Evidence that angiotensin-(17) plays a role in the central control of blood pressure at the ventrolateral medulla acting through specific receptors. Brain Res, 1994, 665, 175-80.

Fornes, P., Richer, C., Vacher, E., Bruneval, P. \& Giudicelli, J. F. Losartan's protective effects in stroke-prone spontaneously hypertensive rats persist durably after treatment withdrawal. J Cardiovasc Pharmacol, 1993, 22, 305-13.

FrankHAM, P. \& CABANAC, M. Nicotine lowers the body-weight set-point in male rats. Appetite, 2003, 41, 1-5.

Frankish, H. M., Dryden, S., Wang, Q., Bing, C., MacFarlane, I. A. \& Williams, G. Nicotine administration reduces neuropeptide $\mathrm{Y}$ and neuropeptide Y mRNA concentrations in the rat hypothalamus: NPY may mediate nicotine's effects on energy balance. Brain Res, 1995, 694, 139-46.

GiUliano, R. \& BREZENOFF, H. E. Increased central cholinergic activity in rat models of hypertension. J Cardiovasc Pharmacol, 1987, 10, 113-22.

Gorbea-Oppliger, V. J., Melaragno, M. G., Potter, G. S., Petit, R. L. \& FINK, G. D. Time course of losartan blockade of angiotensin II hypertension versus blockade of angiotensin II fast pressor effects. J Pharmacol Exp Ther, 1994, 271, 804-10.

Goren, M. Z., Akici, A., Berkman, K. \& OnAt, F. Cardiovascular responses to NMDA injected into nuclei of hypothalamus or amygdala in conscious rats. Pharmacology, 2000, 61, 257-62. 
Gozal, E., Shah, Z. A., Pequignot, J. M., Pequignot, J., Sachleben, L. R., CZyZYK-KrzeskA, M. F., Li, R. C., GuO, S. Z. \& GOZAL, D. Tyrosine hydroxylase expression and activity in the rat brain: differential regulation after long-term intermittent or sustained hypoxia. J Appl Physiol, 2005, 99, 642-9.

Greenberg, M. E., Ziff, E. B. \& Greene, L. A. Stimulation of neuronal acetylcholine receptors induces rapid gene transcription. Science, 1986, 234, 80-3.

Grilli, M., Parodi, M., Raiteri, M. \& Marchi, M. Chronic nicotine differentially affects the function of nicotinic receptor subtypes regulating neurotransmitter release. J Neurochem, 2005, 93, 1353-60.

Grima, B., Lamouroux, A., Blanot, F., Biguet, N. F. \& Mallet, J. Complete coding sequence of rat tyrosine hydroxylase mRNA. Proc Natl Acad Sci U S A, 1985, 82, 617-21.

Haibara, A. S., Colombari, E., Chianca, D. E. Jr., Bonagamba L. G. \& MACHADO, B. H. NMDA receptors in NTS are involved in bradycardic but not in pressor response of chemoreflex. Am J Physiol, 1995, 269(4 Pt 2), H1421-7

HARDY, S. G. Hypothalamic projections to cardiovascular centers of the medulla. Brain Res, 2001, 894, 233-40.

Harfstrand, A., Fuxe, K. \& Agnati, L. F. Evidence that intracisternal injections of cholecystokinin-8 counteracts the cardiovascular effects of intracisternally injected adrenaline and neuropeptide $\mathrm{Y}$ in the alphachloralose anaesthetized rat. J Hypertens Suppl, 1986, 4, S251-3.

Hariharan, M., VAnNoOrd, T. \& Greden, J. F. A high-performance liquidchromatographic method for routine simultaneous determination of nicotine and cotinine in plasma. Clin Chem, 1988, 34, 724-9.

Harland, D., Gardiner, S. M. \& BennetT, T. Paraventricular nucleus injections of noradrenaline: cardiovascular effects in conscious LongEvans and Brattleboro rats. Brain Res, 1989, 496, 14-24.

Hatae, T., Kawano, H., Karpitskiy, V., Krause, J. E. \& Masuko, S. Arginine-vasopressin neurons in the rat hypothalamus produce neurokinin $\mathrm{B}$ and co-express the tachykinin $\mathrm{NK}-3$ receptor and angiotensin II type 1 receptor. Arch Histol Cytol, 2001, 64, 37-44. 
Henningfield, J. E., Miyasato, K. \& Jasinski, D. R. Abuse liability and pharmacodynamic characteristics of intravenous and inhaled nicotine. $\mathbf{J}$ Pharmacol Exp Ther, 1985, 234, 1-12.

Hermann, K., Phillips, M. I. \& Raizada, M. K. Metabolism of angiotensin peptides by neuronal and glial cultures from rat brain. J Neurochem, 1989, 52, 863-8.

Hoffman, W. E., Schmid, P. G. \& Phillips, M. I. Central cholinergic and noradrenergic stimulation in spontaneously hypertensive rats. $\mathbf{J}$ Pharmacol Exp Ther, 1978, 206, 644-51.

Hogg, R. C., Raggenbass, M. \& Bertrand, D. Nicotinic acetylcholine receptors: from structure to brain function. Rev Physiol Biochem Pharmacol, 2003, 147, 1-46.

HwANG, K. R., CHAN, S. H. \& CHAN, J. Y. Noradrenergic neurotransmission at PVN in locus ceruleus-induced baroreflex suppression in rats. Am J Physiol, 1998, 274, H1284-92.

Iitake, K., Share, L., Ouchi, Y., Crofton, J. T. \& Brooks, D. P. Central cholinergic control of vasopressin release in conscious rats. Am J Physiol, 1986, 251, E146-50.

Illes, P., Finta, E. P. \& Nieber, K. Neuropeptide Y potentiates via Y2receptors the inhibitory effect of noradrenaline in rat locus coeruleus neurones. Naunyn Schmiedebergs Arch Pharmacol, 1993, 348, 5468 .

Ishit, K., OdA, Y., ICHIKAWA, T. \& DEguCHI, T. Complementary DNAs for choline acetyltransferase from spinal cords of rat and mouse: nucleotide sequences, expression in mammalian cells, and in situ hybridization. Brain Res Mol Brain Res, 1990, 7, 151-9.

IZQUIERDO, I. \& IZQUIERDO, J. A. Effects of drugs on deep brain centers. Annu Rev Pharmacol, 1971, 11, 189-208.

Kanayama, H., Yasuhara, O., Matsuo, A., Tooyama, I., Aimi, Y., Bellier, J. P., NAgY, J. I., FuKui, K. \& KimurA, H. Expression of a splice variant of choline acetyltransferase in magnocellular neurons of the tuberomammillary nucleus of rat. Neuroscience, 2003, 118, 243-51.

KAschinA, E. \& Unger, T. Angiotensin AT1/AT2 receptors: regulation, signalling and function. Blood Press, 2003, 12, 70-88. 
Kayadjanian, N., Schofield, W. N., Andren, J., Sirinathinghin, D. J. \& BEsson, M. J. Cortical and nigral deafferentation and striatal cholinergic markers in the rat dorsal striatum: different effects on the expression of mRNAs encoding choline acetyltransferase and muscarinic $\mathrm{m} 1$ and $\mathrm{m} 4$ receptors. Eur J Neurosci, 1999, 11, 3659-68.

Keilhoff, G., Seidel, B., Noack, H., Tischmeyer, W., Stanek, D. \& WOLF, G. Patterns of nitric oxide synthase at the messenger RNA and protein levels during early rat brain development. Neuroscience, 1996, 75, 1193-201.

Kelton, M. C., Kahn, H. J., Conrath, C. L. \& Newhouse, P. A. The effects of nicotine on Parkinson's disease. Brain Cogn, 2000, 43, 274-82.

KEnNey, M. J., Weiss, M. L. \& HAYWOOD, J. R. The paraventricular nucleus: an important component of the central neurocircuitry regulating sympathetic nerve outflow. Acta Physiol Scand, 2003, 177, 7-15.

KEW, J. N. \& KEMP, J. A. Ionotropic and metabotropic glutamate receptor structure and pharmacology. Psychopharmacology (Berl), 2005, 179, 4-29.

Kruger, C., Haunstetter, A., Gerber, S., Serf, C., Kaufmann, A., Kubler, W. \& HAASS, M. Nicotine-induced exocytotic norepinephrine release in guinea-pig heart, human atrium and bovine adrenal chromaffin cells: modulation by single components of ischaemia. J Mol Cell Cardiol, 1995, 27, 1491-506.

Kubo, T., Hagiwara, Y., Endo, S. \& Fukumori, R. Activation of hypothalamic angiotensin receptors produces pressor responses via cholinergic inputs to the rostral ventrolateral medulla in normotensive and hypertensive rats. Brain Res, 2002, 953, 232-45.

Kubo, T. \& Misu, Y. Pharmacological characterisation of the alphaadrenoceptors responsible for a decrease of blood pressure in the nucleus tractus solitarii of the rat. Naunyn Schmiedebergs Arch Pharmacol, 1981, 317, 120-5.

Lamba, J. K., Lamba, V., Yasuda, K., Lin, Y. S., Assem, M., Thompson, E., STROM, S. \& SCHUETZ, E. Expression of constitutive androstane receptor splice variants in human tissues and their functional consequences. J Pharmacol Exp Ther, 2004, 311, 811-21. 
LARK, L. A. \& WEYHENMEYER, J. A. The antihypertensive effect of acute intracerebroventricular administration of captopril in Dahl salt-sensitive rats. Eur J Pharmacol, 1992, 222, 33-7.

LAvoie, J. L. \& Sigmund, C. D. Minireview: overview of the renin-angiotensin system--an endocrine and paracrine system. Endocrinology, 2003, 144, 2179-83.

LI, M. D. \& KANE, J. K. Effect of nicotine on the expression of leptin and forebrain leptin receptors in the rat. Brain Res, 2003, 991, 222-31.

Li, M. D., Kane, J. K., Parker, S. L., McAllen, K., MatTa, S. G. \& Sharp, B. M. Nicotine administration enhances NPY expression in the rat hypothalamus. Brain Res, 2000, 867, 157-64.

LI, X. D. \& BuCCAFusCO, J. J. Role of alpha7 nicotinic acetylcholine receptors in the pressor response to intracerebroventricular injection of choline: blockade by amyloid peptide Abeta1-42. J Pharmacol Exp Ther, 2004, 309, 1206-12.

Li, Z., Iwai, M., Wu, L., Shiuchi, T., Jinno, T., Cui, T. X. \& Horiuchi, M. Role of AT2 receptor in the brain in regulation of blood pressure and water intake. Am J Physiol Heart Circ Physiol, 2003, 284, H116-21.

LiU, Z., Chen, C. Y. \& Bonham, A. C. Metabotropic glutamate receptors depress vagal and aortic baroreceptor signal transmission in the NTS. Am J Physiol, 1998, 275, H1682-94.

LOndOn, E. D., Waller, S. B. \& WAmsLeY, J. K. Autoradiographic localization of $[3 \mathrm{H}]$ nicotine binding sites in the rat brain. Neurosci Lett, 1985, 53, 179-84.

LU, J. T. \& CREAGER, M. A. The relationship of cigarette smoking to peripheral arterial disease. Rev Cardiovasc Med, 2004, 5, 189-93.

MACHADO, B. H. Neurotransmission of the cardiovascular reflexes in the nucleus tractus solitarii of awake rats. Ann N Y Acad Sci, 2001, 940, 179-96

MAedA, M., Krieger, A. J., NAKAi, M. \& SAPRU, H. N. Chemical stimulation of the rostral ventrolateral medullary pressor area decreases cerebral blood flow in anesthetized rats. Brain Res, 1991, 563, 261-9. 
Mancia, G., Groppelli, A., Casadei, R., Omboni, S., Mutti, E. \& Parati, G. Cardiovascular effects of smoking. Clin Exp Hypertens A, 1990, 12, 917-29.

MANN, S. J. Neurogenic essential hypertension revisited: the case for increased clinical and research attention. Am J Hypertens, 2003, 16, 881-8.

MARTIN, D. S. \& HAYWOOD, J. R. Sympathetic nervous system activation by glutamate injections into the paraventricular nucleus. Brain Res, 1992, $577,261-7$.

MARTINS, S. M. \& RUDD, D. R. The importance of proper validation of the analytical methods employed in the quality control of pharmaceuticals. Acta Pharm Jugos1, 1990, 40, 7-19.

Matta, S. G., Foster, C. A. \& Sharp, B. M. Nicotine stimulates the expression of $\mathrm{cFos}$ protein in the parvocellular paraventricular nucleus and brainstem catecholaminergic regions. Endocrinology, 1993, 132, 2149-56.

MatTA, S. G., VAlentine, J. D. \& SharP, B. M. Nicotine activates NPY and catecholaminergic neurons in brainstem regions involved in ACTH secretion. Brain Res, 1997, 759, 259-69.

McBride, J. S., Altman, D. G., Klein, M. \& White, W. Green tobacco sickness. Tob Control, 1998, 7, 294-8.

McCann, S. M., Franci, C. R., Favaretto, A. L., Gutkowska, J. \& ANTUNES-RodRIGUES, J. Neuroendocrine regulation of salt and water metabolism. Braz J Med Biol Res, 1997, 30, 427-41.

McKinley, M. J., Albiston, A. L., Allen, A. M., Mathai, M. L., May, C. N., McAllen, R. M., Oldfield, B. J., Mendelsohn, F. A. \& Chai, S. Y. The brain renin-angiotensin system: location and physiological roles. Int J Biochem Cell Biol, 2003, 35, 901-18.

MCNABB, M. E. Chewing nicotine gum for 3 months: what happens to plasma nicotine levels? Can Med Assoc J, 1984, 131, 589-92.

MCNeILL, J. R. Role of vasopressin in the control of arterial pressure. Can J Physiol Pharmacol, 1983, 61, 1226-35.

Mitchell, S. N., Smith, K. M., Joseph, M. H. \& Gray, J. A. Increases in tyrosine hydroxylase messenger RNA in the locus coeruleus after a single dose of nicotine are followed by time-dependent increases in 
enzyme activity and noradrenaline release. Neuroscience, 1993, 56, 989-97.

Miyawaki T., Suzuki S., Minson j., Arnolda L., Chalmers J., LlewellynSMITH I. \& PILOWSKY P. Role of AMPA/kainate receptors in transmission of the sympathetic baroreflex in rat CVLM. Am J Physiol, 1997, 272(3 Pt 2), R800-12.

Murase, S., Takayama, M. \& Nosaka, S. Chemical stimulation of the nucleus locus coeruleus: cardiovascular responses and baroreflex modification. Neurosci Lett, 1993, 153, 1-4.

Muratani, H., Ferrario, C. M. \& Averill, D. B. Ventrolateral medulla in spontaneously hypertensive rats: role of angiotensin II. Am J Physiol, 1993, 264, R388-95.

Najlerahim, A., Harrison, P. J., Barton, A. J., Heffernan, J. \& Pearson, R. C. Distribution of messenger RNAs encoding the enzymes glutaminase, aspartate aminotransferase and glutamic acid decarboxylase in rat brain. Brain Res Mol Brain Res, 1990, 7, 317-33.

Nakajima, M., Yamamoto, T., Kuroiwa, Y. \& Yokoi, T. Improved highly sensitive method for determination of nicotine and cotinine in human plasma by high-performance liquid chromatography. J Chromatogr B Biomed Sci Appl, 2000, 742, 211-5.

Narvaez, J. A., Aguirre, J. A. \& Fuxe, K. Subpicomolar amounts of NPY(13-36) injected into the nucleus tractus solitarius of the rat counteract the cardiovascular responses to L-glutamate. Neurosci Lett, 1993, 151, 182-6.

Neff, R. A., Humphrey, J., Mihalevich, M. \& Mendelowitz, D. Nicotine enhances presynaptic and postsynaptic glutamatergic neurotransmission to activate cardiac parasympathetic neurons. Circ Res, 1998, 83, 1241-7.

Nicholas, A. P., Pieribone, V. \& Hokfelt, T. Distributions of mRNAs for alpha-2 adrenergic receptor subtypes in rat brain: an in situ hybridization study. J Comp Neurol, 1993, 328, 575-94.

Nishimura, M., Milsted, A., Block, C. H., Brosnihan, K. B. \& Ferrario, C. M. Tissue renin-angiotensin systems in renal hypertension. Hypertension, 1992, 20, 158-67. 
Nuyt, A. M., Lenkei, Z., PAlkovits, M., Corvol, P. \& Llorens-Cortes, C. Ontogeny of angiotensin II type 2 receptor mRNA expression in fetal and neonatal rat brain. J Comp Neurol, 1999, 407, 193-206.

OHTA, H. \& TALMAN, W. T. Both NMDA and non-NMDA receptors in the NTS participate in the baroreceptor reflex in rats. Am J Physiol, 1994, 267, R1065-70.

Onai, T., Takayama, K. \& Miura, M. Projections to areas of the nucleus tractus solitarii related to circulatory and respiratory responses in cats. J Auton Nerv Syst, 1987, 18, 163-75.

Osterhout, C. A., Sterling, C. R., Chikaraishi, D. M. \& Tank, A. W. Induction of tyrosine hydroxylase in the locus coeruleus of transgenic mice in response to stress or nicotine treatment: lack of activation of tyrosine hydroxylase promoter activity. J Neurochem, 2005, 94, 731-41.

Ota, M., Crofton, J. T., TobA, K. \& Share, L. Effect on vasopressin release of microinjection of cholinergic agonists into the rat supraoptic nucleus. Proc Soc Exp Biol Med, 1992, 201, 208-14.

PALKovits, M. Distribution of neuroactive substances in the dorsal vagal complex of the medulla oblongata. Neurochem. Int., 1985, 7, 213-219.

Paxinos, G. \& WATSOn, C. (1986) The rat brain in stereotaxic coordinates. Academic Press, inc, San Diego, CA.

Paxton, W. G., Marrero, M. B., Klein, J. D., Delafontaine, P., Berk, B. C. \& BernsteIn, K. E. The angiotensin II AT1 receptor is tyrosine and serine phosphorylated and can serve as a substrate for the src family of tyrosine kinases. Biochem Biophys Res Commun, 1994, 200, 260-7.

Peng, X., Gerzanich, V., Anand, R., Whiting, P. J. \& Lindstrom, J. Nicotine-induced increase in neuronal nicotinic receptors results from a decrease in the rate of receptor turnover. Mol Pharmacol, 1994, 46, 523-30.

Phillips, M. I. \& Sumners, C. Angiotensin II in central nervous system physiology. Regul Pept, 1998, 78, 1-11.

Pieribone, V. A., Brodin, L., Friberg, K., Dahlstrand, J., Soderberg, C., LARHAMMAR, D. \& HOKFELT, T. Differential expression of mRNAs for neuropeptide Y-related peptides in rat nervous tissues: possible evolutionary conservation. J Neurosci, 1992, 12, 3361-71. 
Pinto, Y. M., PAul, M. \& Ganten, D. Lessons from rat models of hypertension: from Goldblatt to genetic engineering. Cardiovasc Res, 1998, 39, 77-88.

Pochiero, M., Nicoletta, P., Losi, E., Bianchi, A. \& Caputi, A. P. Cardiovascular responses of conscious DOCA-salt hypertensive rats to acute intracerebroventricular and intravenous administration of captopril. Pharmacol Res Commun, 1983, 15, 173-82.

PORTER, J. P. Chronic intracerebroventricular infusion of angiotensin II increases brain AT1 receptor expression in young rats. Brain Res Dev Brain Res, 1999, 112, 293-5.

QuIK, M. Smoking, nicotine and Parkinson's disease. Trends Neurosci, 2004, 27, 561-8.

RaO, H., JEAN, A. \& Kessler, J. P. Postnatal ontogeny of glutamate receptors in the rat nucleus tractus solitarii and ventrolateral medulla. J Auton Nerv Syst, 1997, 65, 25-32.

Reis, D. J., Granata, A. R., Joh, T. H., Ross, C. A., Ruggiero, D. A. \& PARK, D. H. Brain stem catecholamine mechanisms in tonic and reflex control of blood pressure. Hypertension, 1984, 6, II7-15.

Riah, O., Courriere, P., Dousset, J. C., Todeschi, N. \& Labat, C. Nicotine is more efficient than cotinine at passing the blood-brain barrier in rats. Cell Mol Neurobiol, 1998, 18, 311-8.

Riftina, F., Angulo, J., Pompei, P. \& MCEwen, B. Regulation of angiotensinogen gene expression in the rat forebrain by adrenal steroid and relation to salt appetite. Brain Res Mol Brain Res, 1995, 33, 201 208.

Robertson, D., Tseng, C. J. \& Appalsamy, M. Smoking and mechanisms of cardiovascular control. Am Heart J, 1988, 115, 258-63.

Ross, C. A., Ruggiero, D. A. \& Reis, D. J. Projections from the nucleus tractus solitarii to the rostral ventrolateral medulla. J Comp Neurol, $1985,242,511-34$.

Russell, M. A., Sutton, S. R., Feyerabend, C., Cole, P. V. \& Saloojee, Y. Nicotine chewing gum as a substitute for smoking. Br Med J, 1977, 1, 1060-3. 
RYAN, R. E. \& LOIACONO, R. E. Nicotine regulates alpha7 nicotinic receptor subunit mRNA: implications for nicotine dependence. Neuroreport, 2001, 12, 569-72.

SAAVEDRA, J. M. Brain angiotensin II: new developments, unanswered questions and therapeutic opportunities. Cell Mol Neurobiol, 2005, 25, 485-512.

SaAvedra, J. M., Israel, A., Plunkett, L. M., Kurihara, M., Shigematsu, K. \& CORREA, F. M. Quantitative distribution of angiotensin II binding sites in rat brain by autoradiography. Peptides, 1986, 7, 679-87.

SAha, S., Drinkhill, M. J., MoOre, J. P. \& BAtTen, T. F. Central nucleus of amygdala projections to rostral ventrolateral medulla neurones activated by decreased blood pressure. Eur J Neurosci, 2005, 21, 1921-30.

Sakai, K., Chapleau, M. W., Morimoto, S., Cassell, M. D. \& Sigmund, C. D. Differential modulation of baroreflex control of heart rate by neuron- vs. glia-derived angiotensin II. Physiol Genomics, 2004, 20, 66-72.

Sallinen, P., SaArela, S., Ilves, M., Vakkuri, O. \& Leppaluoto, J. The expression of MT1 and MT2 melatonin receptor mRNA in several rat tissues. Life Sci, 2005, 76, 1123-34.

Salminen, O., Seppa, T., Gaddnas, H. \& Ahtee, L. The effects of acute nicotine on the metabolism of dopamine and the expression of Fos protein in striatal and limbic brain areas of rats during chronic nicotine infusion and its withdrawal. J Neurosci, 1999, 19, 8145-51.

SANigorski, A., FAhey, R., CAMERON-Smith, D. \& Collier, G. R. Nicotine treatment decreases food intake and body weight via a leptinindependent pathway in Psammomys obesus. Diabetes Obes Metab, 2002, 4, 346-50.

Santos, R. A. \& CAmpagnole-Santos, M. J. Central and peripheral actions of angiotensin-(1-7). Braz J Med Biol Res, 1994, 27, 1033-47.

Santos, R. A., Simoes e Silva, A. C., Maric, C., Silva, D. M., Machado, R. P., De Buhr, I., Heringer-Walther, S., Pinheiro, S. V., Lopes, M. T., Bader, M., Mendes, E. P., Lemos, V. S., Campagnole-Santos, M. J., Schultheiss, H. P., Speth, R. \& Walther, T. Angiotensin-(1-7) is an endogenous ligand for the $G$ protein-coupled receptor Mas. Proc Natl Acad Sci U S A, 2003, 100, 8258-63. 
SAPRU, H. N. (1987) Control of blood pressure by muscarinic and nicotinic receptors in the ventrolateral medulla. In Tobacco smoking and nicotine: a neurobiologic approach., DAVIS, L. ed, pp. 287-300. Plenum Press., New York, NY.

SBH.Hipertensão Arterial. Disponível em http://www.sbh.org.br. Acesso em: 02 de Fevereiro de 2006

Schneider, C., Singewald, N. \& Philippu, A. Inhibition of catecholamine (noradrenline, dopamine) release in the locus coeruleus and hypothalamus by baroreceptor activation: identification of the involved baroreceptors. Naunyn Schmiedebergs Arch Pharmacol, 1995, 352, 291-6.

SCHOEPP, D. D. \& TRUE, R. A. 1S,3R-ACPD-sensitive (metabotropic) $[3 \mathrm{H}]$ glutamate receptor binding in membranes. Neurosci Lett, 1992, $145,100-4$.

SEROVA, L. \& SABBAN, E. L. Involvement of alpha 7 nicotinic acetylcholine receptors in gene expression of dopamine biosynthetic enzymes in rat brain. J Pharmacol Exp Ther, 2002, 303, 896-903.

Shores, M. M., White, S. S., Veith, R. C. \& SzOT, P. Tyrosine hydroxylase mRNA is increased in old age and norepinephrine uptake transporter mRNA is decreased in middle age in locus coeruleus of Brown-Norway rats. Brain Res, 1999, 826, 143-7.

Siess, W., Lorenz, R., Roth, P. \& Weber, P. C. Plasma catecholamines, platelet aggregation and associated thromboxane formation after physical exercise, smoking or norepinephrine infusion. Circulation, 1982, 66, 44-8.

Silva-Antonialli, M. M., Tostes, R. C., Fernandes, L., Fior-Chadi, D. R., Akamine, E. H., Carvalho, M. H., Fortes, Z. B. \& Nigro, D. A lower ratio of AT1/AT2 receptors of angiotensin II is found in female than in male spontaneously hypertensive rats. Cardiovasc Res, 2004, 62(3), 587-93.

Silva, A. P., Xapelli, S., Grouzmann, E. \& Cavadas, C. The putative neuroprotective role of neuropeptide $\mathrm{Y}$ in the central nervous system. Curr Drug Targets CNS Neurol Disord, 2005, 4, 331-47.

Silva, L. C., Fontes, M. A., Campagnole-Santos, M. J., Khosla, M. C., Campos, R. R., JR., Guertzenstein, P. G. \& Santos, R. A. Cardiovascular effects produced by micro-injection of angiotensin-(1-7) 
on vasopressor and vasodepressor sites of the ventrolateral medulla. Brain Res, 1993, 613, 321-5.

Smith, K. M., Mitchell, S. N. \& Joseph, M. H. Effects of chronic and subchronic nicotine on tyrosine hydroxylase activity in noradrenergic and dopaminergic neurones in the rat brain. J Neurochem, 1991, 57, 1750-6.

Speth, R. C., Grove, K. L. \& Rowe, B. P. Angiotensin II and the locus coeruleus. Prog Brain Res, 1991, 88, 217-26.

Steckelings, U., Lebrun, C., QADri, F., Veltmar, A. \& Unger, T. Role of brain angiotensin in cardiovascular regulation. J Cardiovasc Pharmacol, 1992, 19 Suppl 6, S72-9.

Stornetta, R. L., Hawelu-Johnson, C. L., Guyenet, P. G. \& LynCH, K. R. Astrocytes synthesize angiotensinogen in brain. Science, 1988, 242, 1444-6.

Struyker-Boudier, H., Smeets, G., Brouwer, G. \& VAn Rossum, J. Central nervous system alpha-adrenergic and cardiovascular regulation in rats. Arch. Int. Pharmacodyn. Ther., 1975, 213, 235-293.

Sugiyama, Y., Yotsumoto, H., Okabe, T. \& Takaku, F. Measurement of angiotensin-converting enzyme activity in intact human alveolar macrophages and effect of smoking. Respiration, 1988, 53, 153-7.

Sumners, C., Tang, W., Zelezna, B. \& Raizada, M. K. Angiotensin II receptor subtypes are coupled with distinct signal-transduction mechanisms in neurons and astrocytes from rat brain. Proc Natl Acad Sci U S A, 1991, 88, 7567-71.

Sun, B., Chen, X., Xu, L., Sterling, C. \& TAnk, A. W. Chronic nicotine treatment leads to induction of tyrosine hydroxylase in locus ceruleus neurons: the role of transcriptional activation. Mol Pharmacol, 2004, $66,1011-21$.

Sved, A. F. \& FElsten, G. Stimulation of the locus coeruleus decreases arterial pressure. Brain Res, 1987, 414, 119-32.

SwaAB, D. F., PoOl, C. W. \& NiJveldT, F. Immunofluorescence of vasopressin and oxytocin in the rat hypothalamo-neurohypophypopseal system. J Neural Transm, 1975, 36, 195-215. 
Swanson, L. W. \& SAWChenko, P. E. Paraventricular nucleus: a site for the integration of neuroendocrine and autonomic mechanisms. Neuroendocrinology, 1980, 31, 410-7.

Swislocki, A. L., Tsuzuki, A., TAit, M., KhuU, D. \& FAnN, K. Smokeless nicotine administration is associated with hypertension but not with a deterioration in glucose tolerance in rats. Metabolism, 1997, 46, 100812.

TAKAOKA, F. \& MACHADO, B. H. Cardiovascular responses to microinjection of AMPA into the rostral commissural nucleus tractus solitarius of awake rats. Auton Neurosci, 2003, 107 114-119

Talman, W. T., Perrone, M. H. \& ReIs, D. J. Evidence for L-glutamate as the neurotransmitter of baroreceptor afferent nerve fibers. Science, 1980, 209, 813-5.

Talman, W. T., Perrone, M. H. \& Reis, D. J. Acute hypertension after the local injection of kainic acid into the nucleus tractus solitarii of rats. Circ Res, 1981, 48, 292-8.

Tatemoto, K., Carlquist, M. \& MutT, V. Neuropeptide Y--a novel brain peptide with structural similarities to peptide $\mathrm{YY}$ and pancreatic polypeptide. Nature, 1982, 296, 659-60.

Tseng, C. J., Ger, L. P., Lin, H. C. \& Tung, C. S. The pressor effect of nicotine in the rostral ventrolateral medulla of rats. Chin J Physiol, 1994, 37, 83-7.

Tsukamoto, K., Yin, M. \& Sved, A. F. Effect of atropine injected into the nucleus tractus solitarius on the regulation of blood pressure. Brain Res, 1994, 648, 9-15.

Tsutsumi, K. \& SAAvedra, J. M. Angiotensin-II receptor subtypes in median eminence and basal forebrain areas involved in regulation of pituitary function. Endocrinology, 1991, 129, 3001-8.

UNGER, T. Inhibiting angiotensin receptors in the brain: possible therapeutic implications. Curr Med Res Opin, 2003, 19, 449-51.

Ushigome, A., TANAKA, J., Kariya, K. \& Nomura, M. Paraventricular noradrenergic systems participate in angiotensin II-induced drinking. Peptides, 2002, 23, 2169-75. 
Valentine, J. D., Matta, S. G. \& Sharp, B. M. Nicotine-induced cFos expression in the hypothalamic paraventricular nucleus is dependent on brainstem effects: correlations with cFos in catecholaminergic and noncatecholaminergic neurons in the nucleus tractus solitarius. Endocrinology, 1996, 137, 622-30.

van Giersbergen, P. L., Palkovits, M. \& De Jong, W. Involvement of neurotransmitters in the nucleus tractus solitarii in cardiovascular regulation. Physiol Rev, 1992, 72, 789-824.

VArgas, H. M. \& BrezenofF, H. E. Suppression of hypertension during chronic reduction of brain acetylcholine in spontaneously hypertensive rats. J Hypertens, 1988, 6, 739-45.

Veltmar, A., Culman, J., QAdri, F., RAscher, W. \& Unger, T. Involvement of adrenergic and angiotensinergic receptors in the paraventricular nucleus in the angiotensin II-induced vasopressin release. J Pharmacol Exp Ther, 1992, 263, 1253-60.

Wang, H., Gallinat, S., Li, H. W., Sumners, C., Raizada, M. K. \& Katovich, M. J. Elevated blood pressure in normotensive rats produced by 'knockdown' of the angiotensin type 2 receptor. Exp Physiol, 2004, 89, 313-22.

Warner, F. J., Smith, A. I., Hooper, N. M. \& Turner, A. J. Angiotensinconverting enzyme-2: a molecular and cellular perspective. Cell Mol Life Sci, 2004, 61, 2704-13.

Westfall, T. C. \& WatTs, D. T. Catecholamine excretion in smokers and non-smokers. J Appl Physiol, 1964, 19, 40-42.

Wooltorton, J. R., Pidoplichko, V. I., Broide, R. S. \& Dani, J. A. Differential desensitization and distribution of nicotinic acetylcholine receptor subtypes in midbrain dopamine areas. J Neurosci, 2003, 23, 3176-85.

Yang, G., Gray, T. S., Sigmund, C. D. \& CAssell, M. D. The angiotensinogen gene is expressed in both astrocytes and neurons in murine central nervous system. Brain Res, 1999, 817, 123-31.

Yang, S. N., Fior, D. R., Hedlund, P. B., AgnAti, L. F. \& FuxE, K. Selective modulation of the NPY receptors of the Y2 subtype by alpha 2 receptors in the nucleus tractus solitarii of the rat. A cardiovascular and quantitative receptor autoradiographical analysis. Brain Res, 1994a, 654, 137-44. 
Yang, S. N., Fior, D. R., Hedlund, P. B., Narvaez, J. A., Agnati, L. F. \& FuXE, K. Coinjections of NPY(1-36) or [Leu31,Pro34]NPY with adrenaline in the nucleus tractus solitarius of the rat counteract the vasodepressor responses to adrenaline. Neurosci Lett, 1994b, 171, 27 31.

Yang, S. N., Narvaez, J. A., Bjelke, B., Agnati, L. F. \& Fuxe, K. Microinjections of subpicomolar amounts of NPY(13-36) into the nucleus tractus solitarius of the rat counteract the vasodepressor responses of NPY(1-36) and of a NPY Y1 receptor agonist. Brain Res, 1993, 621, 126-32.

Yettefti, K., Orsini, J. C. \& Perrin, J. Neuronal responses to systemic nicotine in the solitary tract nucleus: origin and possible relation with nutritional effects of nicotine. Pharmacol Biochem Behav, 1997, 58, 529-35.

Yongue, B. G., Angulo, J. A., McEwen, B. S. \& Myers, M. M. Brain and liver angiotensinogen messenger RNA in genetic hypertensive and normotensive rats. Hypertension, 1991, 17, 485-91.

Yoshimura, R., Xu, L., Sun, B. \& TAnK, A. W. Nicotinic and muscarinic acetylcholine receptors are essential for the long-term response of tyrosine hydroxylase gene expression to chronic nicotine treatment in rat adrenal medulla. Brain Res Mol Brain Res, 2004, 126, 188-97.

ZAmbOni, I. \& DE MARTinO, C. Buffered picric acid formaldehyde: a new rapid fixative for electron microscopy. J Cell Biol, 1967, 35, 148A.

ZaninetTi, M., Tribollet, E., Bertrand, D. \& Raggenbass, M. Nicotinic cholinergic activation of magnocellular neurons of the hypothalamic paraventricular nucleus. Neuroscience, 2002, 110, 287-99.

Zoli, M., Zini, I., Agnati, L., Guidolin, D., Ferraguti, F. \& Fuxe, K. Aspects of neuronal plasticity in the central nervous system. I. Computer-assisted image analysis methods. Neurochem. Int, 1990, 16, 383-418. 
APÊNDICE 


\section{APÊNDICE}

Os resultados do presente trabalho foram apresentados em congressos nacionais e internacionais, bem como foram submetidos a publicação, e os dados estão sendo compilados para elaboração de artigos científicos.

\section{Trabalho submetido a publicação:}

FERrARI, M.F.R. \& FIOR-CHADI, D.R. (2006). Chronic nicotine administration. Analysis of the development of hypertension and glutamatergic neurotransmission. The Journal of Hypertension

\section{Manuscrito em preparação:}

FERrARI, M.F.R.; FIOR-CHADI, D.R. \& RAIZADA M.K. (2006). Differential regulation of the Renin-Angiotensin System by nicotine in wky and shr glia.

\section{Congresso Internacional:}

FErrari, M.F.R. \& FIOR-ChADI, D.R. (2004). Peripheral nicotine administration modulates neurotransmission in brain cardiovascular areas of spontaneously hypertensive rats. II International Congress on Neuroregeneration. Rio de Janeiro.

\section{Congresso Nacional:}

FERrARI, M.F.R. \& FIORChADI, D.R. (2004). Nicotine differentially increases tyrosine hydroxylase immunoreactivity in some of the brain cardiovascular areas of Wistar Kyoto and spontaneouly hypertensive rats. XIX Congresso da Federação de Sociedades em Biologia Experimental. FeSBE. Águas de Lindóia. 